Historic, Archive Document

Do not assume content reflects current scientific knowledge, policies, or practices. 

United States

Department of

Agriculture

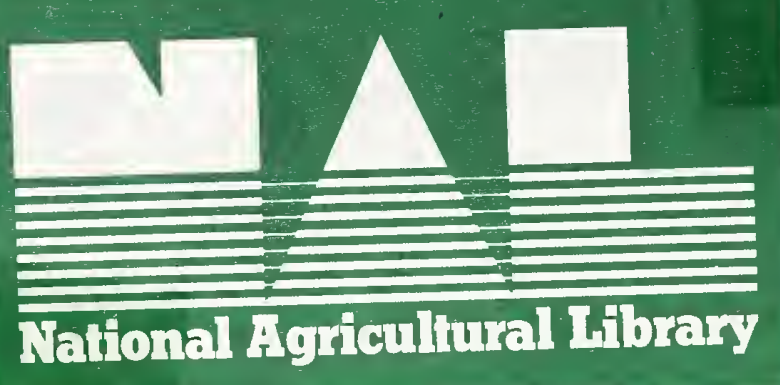




\section{FOREST \\ HABITAT \\ for \\ REPTILES \& \\ AMPHIBIANS \\ of the \\ NORTHEAST}

by

Richard M. DeGraaf

Principal Research Wildlife Biologist Northeastern Forest Experiment Station

Amherst, Massachusetts

Deborah D. Rudis

Wild ife Technician

Northeastern Forest Experiment Station

Amherst, Massachusetts

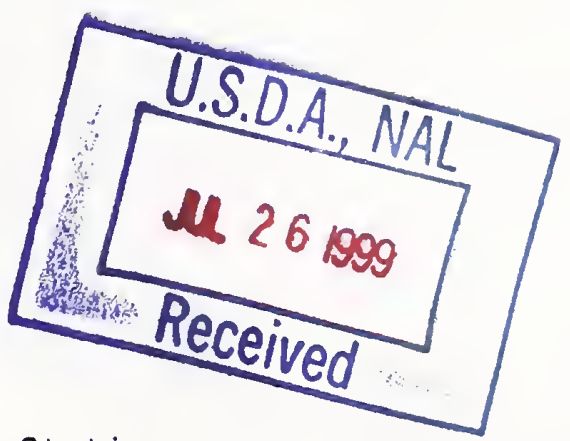

Northeastern Forest Experiment Station

$$
\begin{gathered}
\text { and } \\
\text { Eastern Region }
\end{gathered}
$$

FOREST SERVICE

U.S. DEPARTMENT OF AGRICULTURE 
$5 x+5$

-

- 19001 


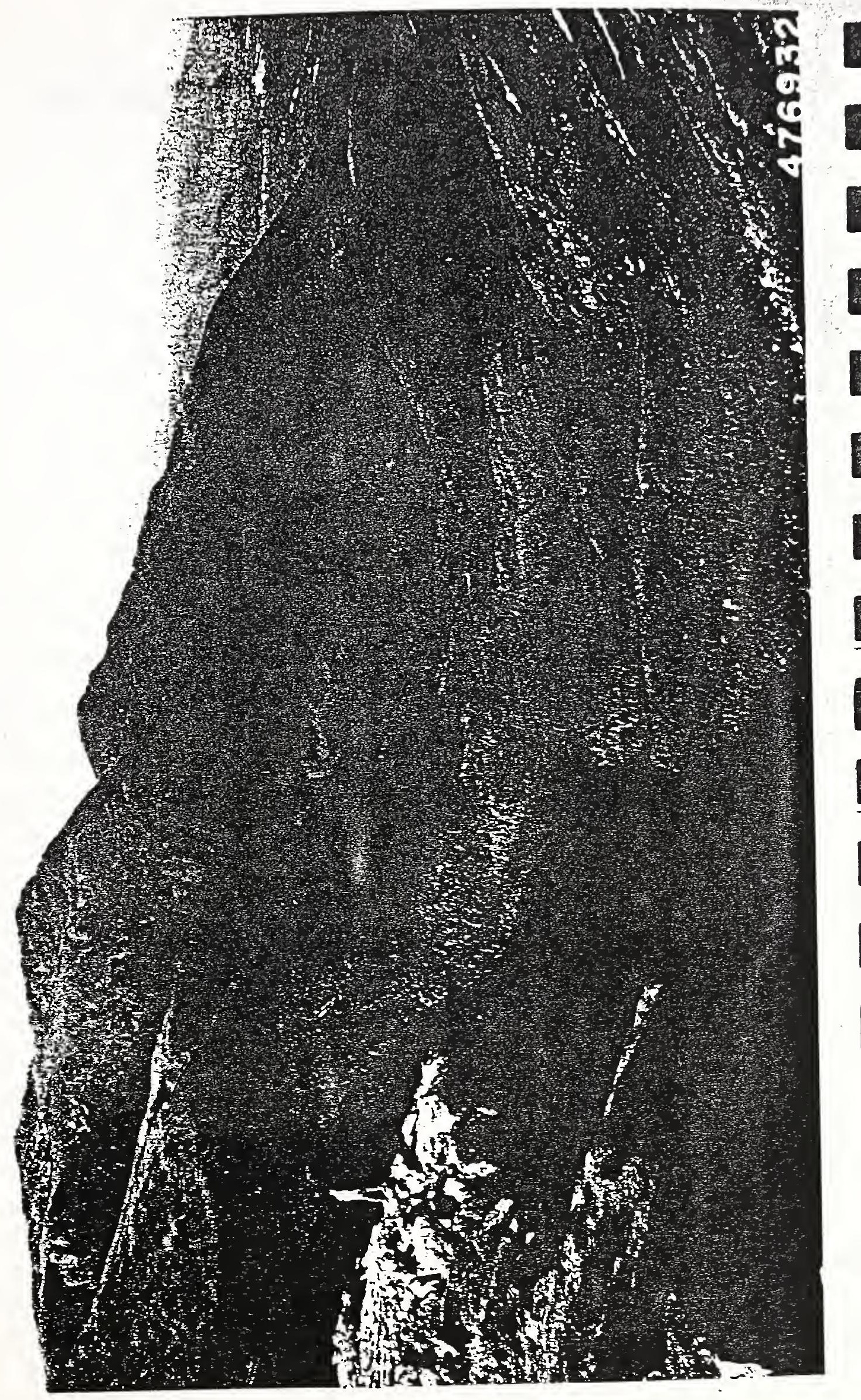




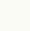




\section{ACKNOWLEDGMENTS}

We gratefully acknowledge those who helped in this work. The following willingly reviewed the manuscript and made many contributions and useful suggestions: Thomas J. Andrews, University of Massachusetts, Amherst, Terry E. Graham, Worcester State College, Worcester, Massachusetts, Michael W. Klemens, American Museum of Natural History, James D. Laze11, Center for Action on Endangered Species, Ayer, Massachusetts, Margaret M. Stewart, State University of New York at Albany and Thomas F. Tyning, Massachusetts Audubon Society, Hampden, Massachus etts .

There are many others who helped with this manual by providing information and offering their expertise and encouragement. We would like to thank them for their contributions to the content of this manual, but space limits us from naming them all.

Special thanks to Dottie McDougal and Freddie Morrill for patiently typing several drafts of the manuscript. Illustrations were done by Barbara Terkanian of Concord, Massachusetts.

This management guide is the first such undertaking for the herpetofauna of the northeastern United States. This data base can be improved when new information is discovered. Some details provided in this manual may be reevaluated. Any comments or questions should be addressed to the authors at:

USDA - Forest Service Northeastern Forest Experiment Station Hilton House University of Massachusetts Amherst, MA 01003 



\section{FOREWORD}

Approximately 75 species and subspecies of amphibians and reptiles occur in the eight-state New England Planning Area of the Eastern Region, Forest Service, U.S. Department of Agriculture. Some species are widely distributed and well-known, but the occurrence and even the life histories of many others are very poorly known.

The Forest Service is committed to the maintenance of natural communities. Amphibians and reptiles comprise a rich biological resource, and consideration of their habitat requirements is essential to a sound land management program.

This publication provides the most comprehensive information available on the natural histories and habitat associations of amphibians and reptiles within forest environments of the Northeast. The information will help Federal and State land management agencies, as well as private organizations, plan for the habitat needs of these important species in the management of public and private forest lands.

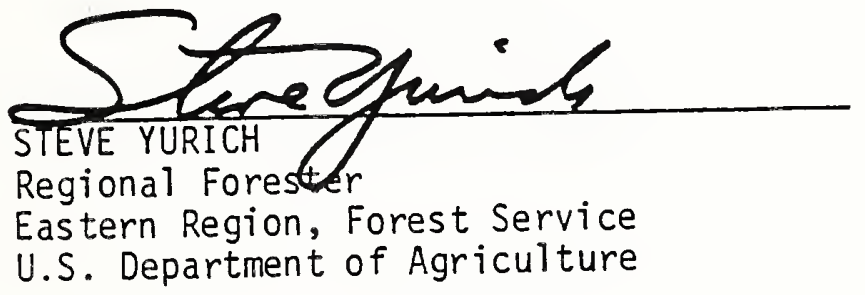





\section{LIST OF TABLES}

\section{TABLE}

1 Forest Community Types -- New England Area . . . . . .

2 Amphibians with Special State Status in the Northeast .

3 Reptiles with Special State Status in the Northeast ...............

4 Timbered Community Types -- New England Area ......

5 Non-timbered Community Types -- New England Area ...

\section{LIST OF FIGURES}

\section{FIGURE}

1 New England Planning Area -- Eastern Region, USDA Forest Service

2 Plant Community Classifications 


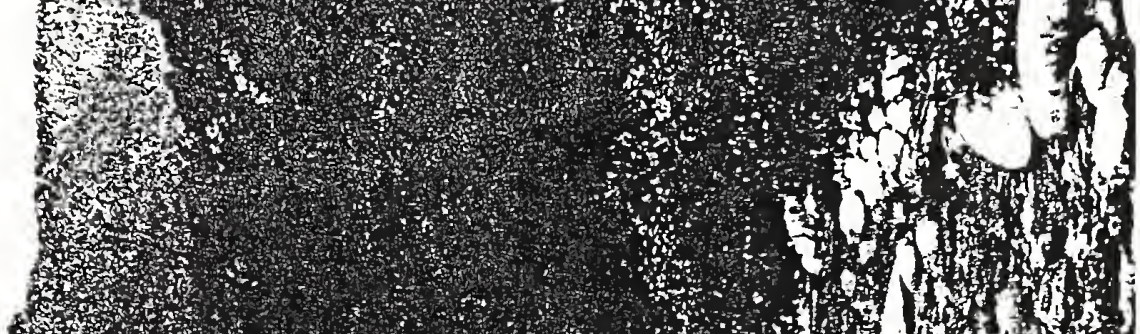

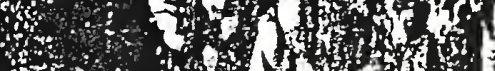
on 140 +4
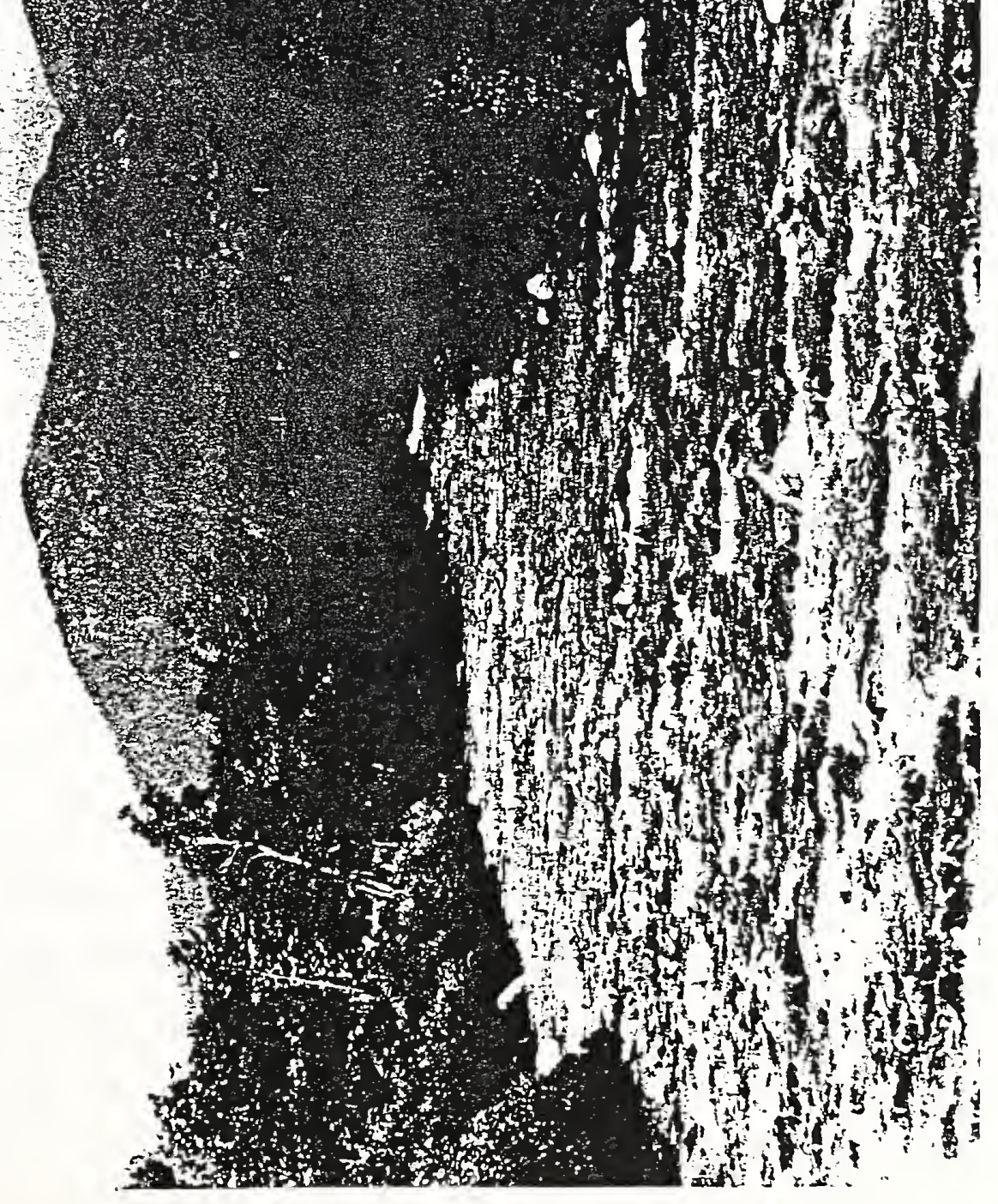

$=\stackrel{2}{\infty}$

क्ष

年声迹

은 닌

\&

들

น.

도 $\frac{1}{3}$ ก

$y$ u

ज品

$\therefore$

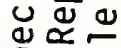

in

$=\dot{\omega}$

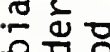

을

등몽

厅

的学

느

$+\stackrel{\Theta}{\Sigma}$

里它

응으

ํㅗㄴ

돈

용

둔

옹옹

बै

음 号宁

象

立.

น ล

的要

व $=$

5 ᄂ

ज定

응

कर

^ $>0$

के $\vec{y}$

$\geq \stackrel{2}{2}$

$\therefore$ 함 



\section{INTRODUCTION}

The habitat associations of amphibians and reptiles are generally not as well known as those of birds and mammals. Indeed, we know little about the life history, status, and distribution of many species. Amphibians and reptiles are important components in the functioning of forest and other ecosystems, but they are often omitted from wildlife management plans because their habitat needs, and even their presence, are so poorly described. Some species may be quite abundant, yet are rarely encountered due to their fossorial habits, nocturnal activities, or limited movements.

The size, distribution, and variety of wildlife populations are functions of the amount, diversity and quality of available habitats, among other factors. Sound wildlife management is, therefore, dependent upon the systematic accumulation and analysis of habitat data.

Our purpose here is to assemble natural history profiles of these species and their associations with forest types and age classes. These associations, presented for both timbered and non-timbered communities, will enable forest managers or wildlife biologists to describe the general herpetofauna to be found in a given forest community or age class. The natural history profiles provide additional detailed habitat? or life history information.

Management of wildlife on public lands is a reponsibility shared by the various states and federal land management agencies. By agreement, states manage or regulate wildlife populations and federal agencies 

manage habitats. Naturally, close cooperation is required to meet wildlife management goals. This manual provides only habitat information--wildlife population goals must be developed through the coordination or activities of all involved agencies.

Recent legislation has mandated that ecological considerations have an important role in forest management and related resource-use decisions and includes:

1. Fish and Wildlife Coordination Act (16 U.S.C. 661-666c, 1934 as amended). It seeks to protect fish and wildlife habitats by requiring the U.S. Fish and Wildlife Service and the National Marine Fisheries Service to review and report on proposed water and associated land development projects. Evaluations cover projects receiving Federal funds and those permitted under Sections 9 and 10 of the River and Harbor Act of 1899, Sections 402 and 404 of the Federal Water Pollution Control Act amendments of 1972, and other appropriate Acts.

2. Multiple Use and Sustained Yield Act of 1960 (P.L. 86-517). It directs the U.S. Forest Service to consider all renewable resources in conjunction with one another.

3. National Environmental Policy Act of 1969 (P.L. 91-190). It encourages productive harmony among man and his environment. It requires any Federally financed project be evaluated and environmental impacts, including those on fish and wildlife, and alternative opportunities be identified.

4. Endangered Species Act of 1973 (P.L. 93-205). It calls for conservation of endangered and threatened species, and of the ecosystems supporting them. Critical habitats, required to assure survival and restoration of endangered species are identified, delineated, and maintained.

5. Sikes Act of 1974 (P.L. 93-452). It calls for new directions and cooperation with the states in planning and management of wildlife habitat on Federal lands.

6. Forest and Rangeland Renewable Resources Planning Act of 1974 (P.L. 93-378). It directs the U.S. Forest Service to inventory natural resources in the National Forest System and provide comprehensive plans for their management. 

7. Federal Land Policy and Management Act of 1976 (P.L. 94-579). It established national policy to retain rather than dispose of the National Resource Lands, and directs that those lands be inventoried, uses be planned on a multiple-use and sustained-yield basis, and that lands be managed on a sound ecological basis, with habitat provided for fish and wildlife. Land-use plans and regulations must include protection of public land areas of critical environmental concern. This means delineated areas of public lands where special management attention is required, among a broad spectrum of purposes, to protect and prevent irreparable damage to important fish and wildlife resources or other natural systems or processes. In resource inventories, priority shall be given to designation and protection of areas of critical environmental concern.

8. National Forest Management Act of 1976 (P.L. 94-588). It requires, among other things, that research be conducted to ensure that land management systems will not substantially impair land productivity.

Most fungst wildlife habitat management efforts are results or consequences of forest management practices. Thus wildlife habitat associations need to be expressed in terms of forest management. Through knowledge of the habitat requirements of wildlife species and species groups, the biologist can prescribe habitat treatments to satisfy wildlife needs. Habitat management can be planned for wildlife communities or for enhancement of specific species, such as endangered species.

Managers of public lands are responsible for determining the effects of management activities upon all wildlife, including amphibians and reptiles. Without a fairly complete knowledge of the natural history and habitat associations of amphibians and reptiles, management programs that consider these species cannot be properly developed. In order to predict the effects of land management practices on a species or species group, the habitat requirements of each must be understood. 

Because many amphibians and reptiles have small home ranges and seldom move far from their natural habitats, silvicultural practices that alter community types can eliminate local populations. Where endangered or threatened species or isolated populations occur, management practices need to be carefully reviewed for their possible impacts. With increasing demands for timber production and recreational uses of public forest lands, wildlife habitat requirements must be defined and analyzed in each community type for true multiple-use planning.

\section{SPECIES ACCOUNTS}

This manual presents to the forester and biologist information on the natural history of amphibians and reptiles that occur in the Northeast, although this information has wider geographic applications. We assembled this information from the available literature, expert reviews, and continuing field research. Natural history profiles and tables describe each species' occurrence in the major forest (community) types and age classes (successional stages) of the Northeast.

Information for the life history accounts is taken from studies conducted in the Northeast when such references were available. Where information from states outside the region is included, the locality of the research is noted in the text.

The relative abundance indicated in each species account is an approximation; for more specific information, the status tables should be consulted. Included in the habitat section are details from 

knowledgeable local herpetologists. Habitat use during breeding and hibernation periods is summarized in this section, and, if specific habitat components are required by a species, they are listed under Special Habitat Requirements. The Comments section provides an assortment of additional information to better acquaint the user with each species.

Often life history information is unavailable; further research is needed to fill existing gaps. Key life history references are listed at the end of each species account. They are not necessarily the most recent references, but are included because they are the most complete general references available.

\section{SPECIES INCLUDED}

The 75 amphibians and reptiles in this guide were selected because all or part of their ranges fall within the New England Planning Area of the Eastern Region, USDA Forest Service (Fig. 1). Introduced species that have established populations in parts of the region have also been included.

Although the guide is limited to amphibians and reptiles of the eight-state New England Planning Area, the natural history profiles and range maps include information on these species in thirteen northeastern states. This was done to make the guide useful to biologists and foresters in states where most of these forest (community) types and species are also found. 



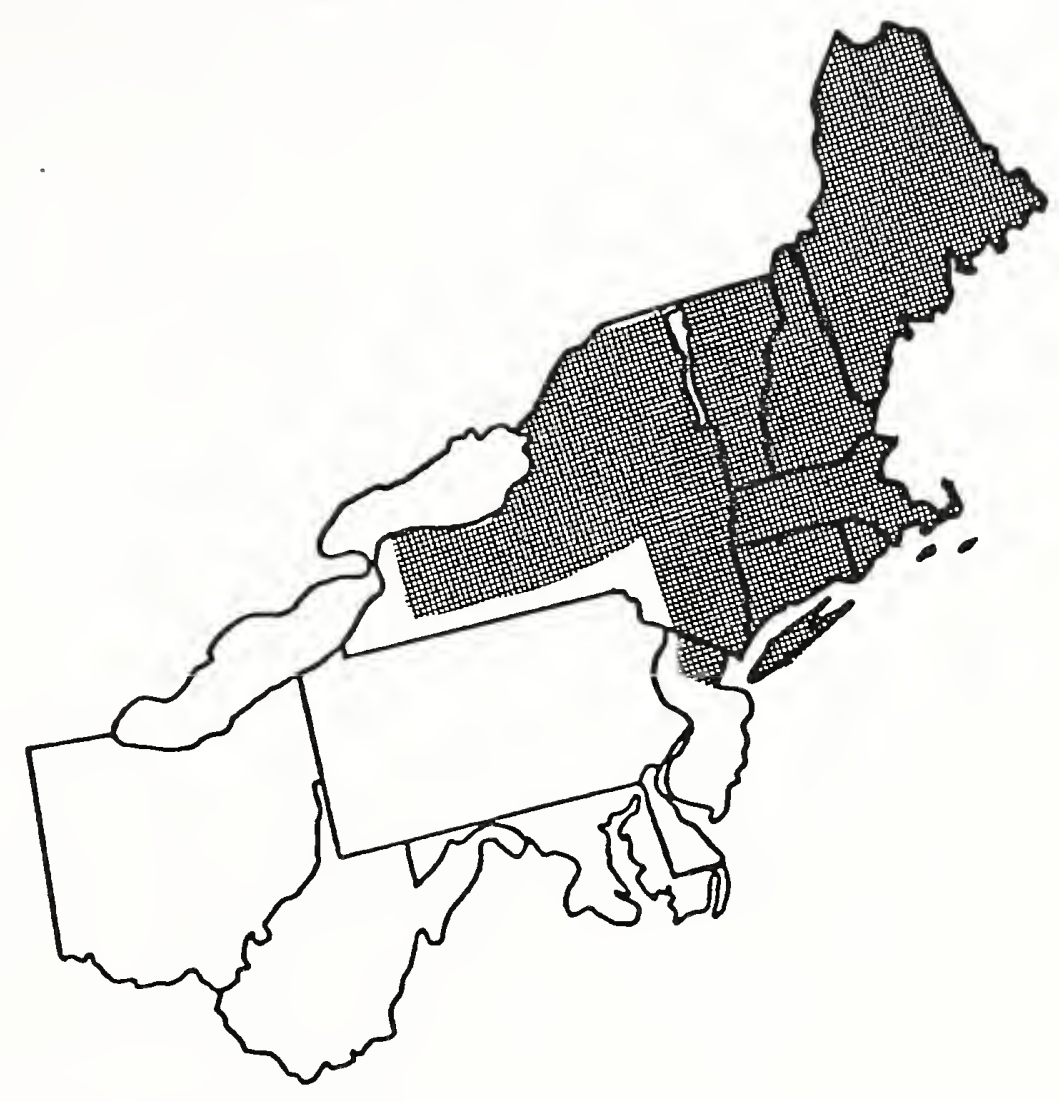

Figure 1. Map of the New England Planning Area, Eastern Region, USDA Forest Service.

The scientific names follow those used in Collins et a1. (1978): Standard Common and Current Scientific Names for North American Amphibians and Reptiles, except for the greater and lesser treefrogs (Hyla v. versicolor, H. v. chrysoscelis) which are considered separate subspecies in accordance with Fellers' (1979) paper addressing this distinction. 



\section{DISTRIBUTION MAPS}

A map of each species' approximate distribution in the Northeast is included with its natural history profile. The map shows the extent of the continuous range, but because the maps were derived from the literature and not from museum or voucher specimens, the continuous range may include areas where a species has not been found but is presumed to occur. Some subspecies may show geographic overlap but will not occupy the same habitat within the same range.

\section{SPECIES/HABITAT TABLES}

Summaries of species' associations with community types are presented in tabular form. The amphibians and reptiles of timbered and non-timbered community types are presented separately. Species occurrence is listed for the White and Green Mountain National Forests, the two Forests for which this guide was originally developed. To make this manual useful to other agencies, organizations, or individuals, the local occurrence column is left blank--it can be checked as a reference for species' occurrence in other localities. Also, blank lines are provided for the inclusion of additional species.

The forest community types in the New England Area are presented with age groups as they exist under even age management (Table 1). Only in Northern Hardwoods-Hemlock is an all-age group shown. These community types are the basic forest classification units upon which this guide is based. This particular scheme is used in National Forest planning and is described in the U.S. Forest Service Compartment 

Prescription Handbook (USDA 1981). The relationships between this classification scheme and other plant classification systems are presented in Figure 2.

Since most northeastern amphibians require water for breeding, there may be no direct relationship between their occurrence and forest type or age class on their breeding territories. Indirect relationships may occur when vegetative cover in riparian zones affects water temperature, $\mathrm{pH}$, or the presence and type of bottom litter. Some species may be found in a wide range of forest community types if the required aquatic habitat component is present within those types. Some terrestrial microhabitats of forest communities may be equally important in determining species occurrence (Krysik 1980). Pollutants may impose a further limitation on occurrence of some species (Gochfeld 1975). The life history accounts in this manual, used in conjunction with the tables, will provide this cautionary information. Further research in the field is necessary for determining more specific habitat relationships of amphibians and reptiles.

Definitions of the terminology used in the tables are found in the following section. Non-timbered type definitions are taken from the Forest Service Compartment Prescription Handbook (USDA 1981). 



\section{COMMUNITY TYPES}

The forest community types in the New England Area are presented below with age groups as they exist under even age management. Only in Northern Hardwoods-Hemlock is an all-age group shown. These community types are the basic forest classification units upon which this guide is based.

Table 1. AGE GROUPS OF TIMBERED COMMUNITY TYPES -

NEW ENGLAND AREA.

Community Type-1/

Aspen

Birch

Northern HardwoodHemlock

Swamp Hardwoods

\section{Age Classes-}

$R$
$Y$
$M$
$O$

$R$

Y

$M$

0

$R$

Y

M

0

A

$\begin{array}{ll}R & 0-9 \\ Y & 10-59 \\ M & 60-119 \\ 0 & 120+\end{array}$

$$
\begin{gathered}
0-9 \\
10-39 \\
40-59 \\
60+
\end{gathered}
$$

$$
\begin{gathered}
0-9 \\
10-49 \\
50-79 \\
80+
\end{gathered}
$$

$$
0-9
$$

$10-59$

$60-119$

$120+$

a 11 -aged
Timber Species or Age (yrs.) Groups Included

Quaking aspen

Big-tooth aspen

Aspen-fir

Paper birch

Sugar maple-beechyellow birch

Red maple (dry)

Sugar maple

Beech

Black ash-American elm-red maple

Red maple (wet) 

AGE GROUPS OF TIMBERED COMMUNITY TYPES - NEW ENGLAND AREA (cont'd.)

Community Type-

Northern Red Oak

Oak-Pine

Balsam Fir

Pine

Spruce-fir

Spruce

Hemlock

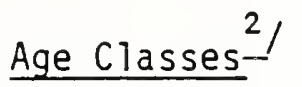

Age (yrs.)

$0-9$

$10-59$

$60-99$

$100+$

$0-9$

10-59

$60-99$

$100+$

$0-9$

10-39

40-69

$70+$

$0-9$

$10-69$

$70-119$

$120+$

$0-9$

10-39

40-89

$90+$

$0-9$

$10-39$

40-99

$100+$
Timber Species or Groups Included

Northern red oak

Other oak-pine White pine-red oakash

Balsam-aspenpaper birch

Red pine White pine White pine-hemlock

Red spruce-balsam fir Northern white cedar Mixed swamp conifer Cedar-aspen-paper birch

Red spruce

Hemlock

$\begin{array}{lcc}R & 0-9 & \text { Hemlock } \\ Y & 10-69 & \\ M & 70-119 & \\ 0 & 120+ & \end{array}$

$1 /$ Forest types such as pitch pine, oak-hickory and tulip poplar occur in New England, but are not typically major components of New England forests.

$2 / R$ - Regenerating

$S$ - Seed ling/sapling

Y - Young, poles

M - Mature

0 - 0ld growth, pathological rotation age

A - A11-aged 



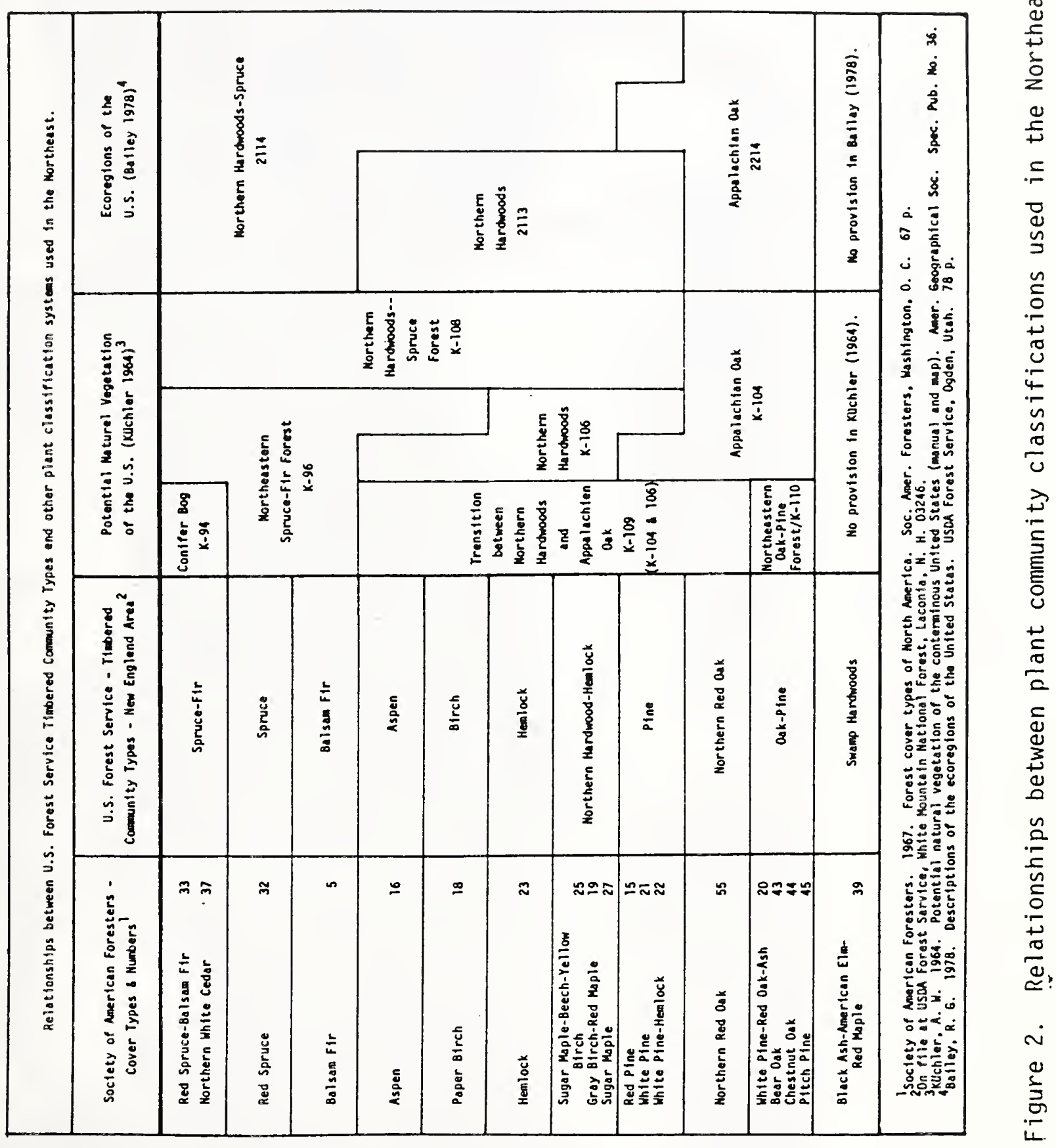





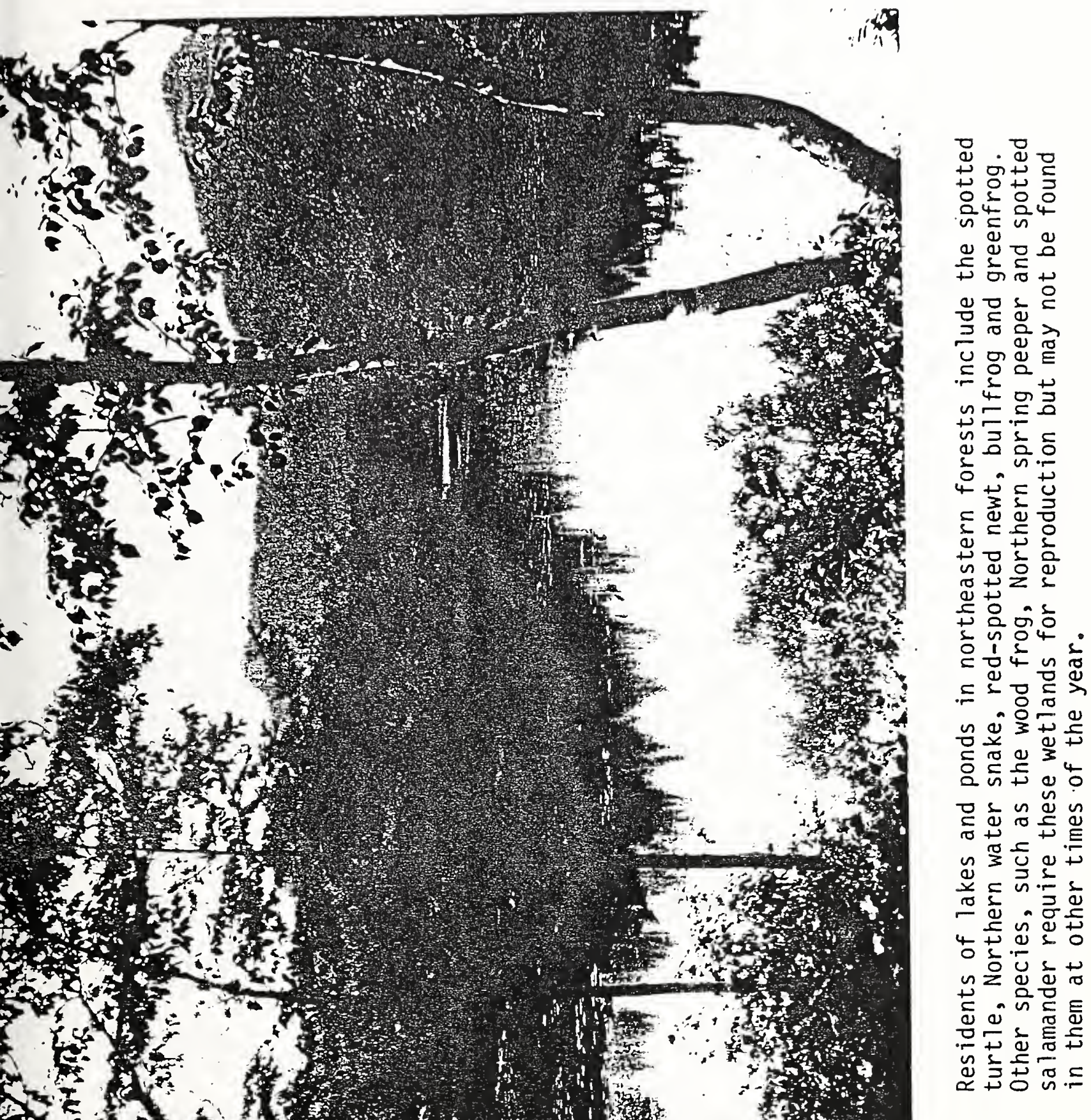



Home Range - The area traversed by any individual animal during its normal life. Individuals, pairs, or family groups of animals commonly restrict their activities to a definite home range.

Krummolz Zone - The transition zone from subalpine forest to alpine tundra characterized by dwarfed, deformed, wind-sheared trees.

Mature Stands - Areas covered by trees of small sawtimber size--larger than 9 in $(22.9 \mathrm{~cm}) \mathrm{dbh}$ if conifers, and 11 in $(27.9 \mathrm{~cm}) \mathrm{dbh}$ if hardwoods. Competition between trees has eliminated some overtopped or diseased individuals. Shade tolerant species such as beech, hemlock, and sugar maple are common in such stands. Very few large trees $(14 \mathrm{in}, 35.6 \mathrm{~cm}$, or more $\mathrm{dbh}$ ) or snags are present in such stands, and dense shade prevents understory development, although some understory plants exist.

Nonvegetative, Rock, Sand, Mud, etc. - Land components which do not conform to the definitions for other non-timbered community types. Generally has a geologic origin, but may include man-made habitats such as gravel pits, quarries, buildings, human debris, and other structures.

01d Growth - Areas covered by trees which are on the average larger than 14 in $(35 \mathrm{~cm})$ dbh with diseased and damaged trees becoming noticeable as they approach pathological (natural) rotation. Snags for cavity nesters become apparent; mortality and windfall create small clearings that soon become pockets of regenerating growth.

Opening - Land on which grasses, herbs, and shrubs dominate the vegetation, including but not limited to "nonforest" and "unproductive forest." Openings may include some trees.

Opening-Undifferentiated - A land area having high solar illumination at the ground level. An opening can be dominated by land features such as water or rock or by vegetation features such as grasses, forbs, or shrubs.

Orchard - Areas one-half acre (0.2 ha) or larger where fruit trees-usually apple--are abundant. Groups of trees can be classified as "orchard" if they occur in clumps of five or more trees or where there are more than 10 trees per acre $(0.4 \mathrm{ha})$. At this tree density, the fruits produced constitute a significant food source for many wildlife species.

Pasture - Grazing land under relatively intensive management, usually supporting introduced forage species, and receiving periodic cultural treatment such as tillage, fertilization, mowing, and irrigation. 

Regenerating Stands - Areas in the process of being restocked with trees by natural means or by planting. Trees are of seedling and small sapling size--up to 5 in $(12.5 \mathrm{~cm}) \mathrm{dbh}$. Tree species present are very tolerant of shade such as aspen, cherry, paper birch, and sometimes pine. Stands in this size group are important in producing grasses, forbs, and shrubby growth in abundance for ground-nesting and feeding birds.

Relative Abundance - abundant - very plentiful common - readily found to be present uncommon - not readily found, but present rare - present in such low numbers that a finding is considered noteworthy.

Riparian - The banks and adjacent areas of water bodies, water courses, seeps, and springs whose water provide soil moisture sufficiently in excess of that otherwise available locally so as to provide a more moist habitat than that of continguous floodplains and uplands.

Savanna - Land areas dominated by grasses and sedges, with open stands of widely spaced trees. A savanna results from either soil-moisture regimes or disturbances such as fire or grazing.

Shrub - A plant that has persistent, woody stems and a relatively low growth habit, and generally produces several basal shoots instead of a single bole.

Vegetation - Submergent - Plants which grow below the water surface. Flowering parts of some species may be above the water surface.

Emergent - Vegetation with submerged roots and leafy parts above the water surface. Herbs growing out of water, but on saturated soils are included in this definition.

Surface - Floating plants with most of plant occurring on the water surface.

Wildlife Habitat - The plant where animals live. Also refers to the plant communities upon which they are dependent for their livelihood.

Young Stands - Areas in the process of becoming dominated by tree species rather than by shrubs, forbs, or grasses. Tree stems are of sapling size, averaging 5 to 9 in $(12.5$ to $23 \mathrm{~cm}) \mathrm{dbh}$ in softwoods and 5 to 11 in $(12.5$ to $27.5 \mathrm{~cm}) \mathrm{dbh}$ in hardwoods. More tolerant species such as red maple and yellow birch, are commonly found in young stands. 



\section{AMPHIBIAN AND REPTILE STATUS RATINGS}

There are presently 47 species of amphibians and reptiles occurring within the eight states of the Northeast region that have special status. Their inclusion on a rare and endangered species list was developed by State and Federal agencies or special study groups. Species listings are provided on a state-by-state basis, therefore, the status designation in one state may differ from the status of the species in an adjacent state (Tables 2 and 3). Species status accompanied by protective legislation is denoted by an asterisk.

The information provided in Tables 2 and 3 is current as of April 1981. The list has been supplemented with additional state data obtained from revision work currently in progress since the original publication date. Spaces are provided at the end of each table for the inclusion of additional species as needed.

Terms in the lists and abbreviations found in Tables 2 and 3 are defined as follows:

Society for the Study. of Amphibians and Reptiles (SSAR)

Ashton, Ray E.

1976. Endangered and threatened amphibians and reptiles in the United States. Soc. Study Amphib. Rept., Misc. Publ., Herpetol. Circ. 5. 65pp.

Taxa are classified with respect to their status in each state. The state abbreviation follows the classification on the table. 

E (Endangered) - A taxon that has become reduced in numbers throughout its range (or had its habitat reduced) to such a point that reproductive populations are extremely small or vulnerable to extirpation.

T (Threatened) - A taxon that is represented in only a limited part of what was once its total range, with reduced populations due to habitat destruction or poor State or Federal management.

R (Rare) - Those species or subspecies that are considered rare throughout the state or are found in environmental conditions disjunct from the normal geographic range of the species.

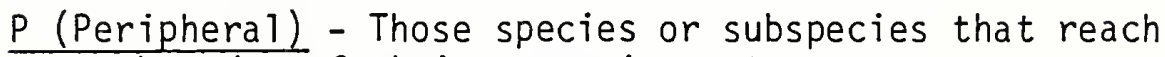
the edge of their range in a state.

U.S. Department of the Interior, Fish and Wildlife Service. 1980. Endangered and threatened wildlife and plants-republication of list of species. Federal Register 45(99): 33768-33781.

E (Endangered) - Those species in danger of extirpation throughout all or a significant portion of the ir range.

I (Threatened) - Those species likely to become endangered within the foreseeable future throughout all or'a significant portion of their range.

The eight states included on this list have agreed to protect all species that are Federally listed. Further protection for amphibians and reptiles has been legislated in Massachusetts, New Jersey, New York, and Rhode Island at this writing. Maine, New Hampshire, and Connecticut have developed lists of the less common species but have not provided legal status as yet. 

MAINE

Species unofficially listed for future consideration:

Center for Natural Areas.

1976. Reptiles and amphibians. Pages 260-265 In

A preliminary listing of noteworthy and natural features

in Maine. A report prepared for the Critical Areas

Program.

$$
\begin{aligned}
& \frac{R \text { (Rare) }}{\text { of } 1 \text { to } 4 .} \\
& \qquad \begin{array}{l}
1=\text { common } \\
4=\text { rare }
\end{array}
\end{aligned}
$$

SL (State Local) - Long-established breeding or wintering species in the Commonwealth that are restricted to very limited areas. A few species (SLA) which are widespread but nowhere frequent, are also included.

\section{CONNECTICUT}

Species unofficially listed for future consideration:

Dowhan, J. J., and R. J. Craig.

1976. Rare and endangered species of Connecticut and their habitats. State Geological and Natural History Survey of Connecticut. Rep. of Investigations No. 6 . $137 \mathrm{pp}$.

E (State Endangered Taxon) - In danger of extinction in Connecticut as a reproducing taxon; rare or very local throughout a 11 or much of its range, or having a relatively restricted geographic range.

D (State Declining Taxon) - A threatened taxon, whose populations are currently undergoing a prolonged, noncyclic decline in Connecticut and in many other parts of its range, and is either approaching rarity or is already very rare in the State. These taxa are likely to become endangered within the near future in the State. 



\section{MASSACHUSETTS}

Certain species are legally protected:

Code of Massachusetts Regulations, 321 CMR part 3.05 authorizes the Division of Fish and Wildlife to promulgate regulations of Massachusetts General Laws Chapter 131, Section 5. (April 1980).

P - Protected.

$\underline{S}$ - Season set for hunting or taking species.

Listed species with no legal status obtained from revision of publication (in progress):

Massachusetts Division of Fisheries and Wildlife.

1978. Species for special consideration in Massachusetts.

Pub1. No. 11094-5-100-12-78-CR.

E (Endangered) - Any species which is in danger of extinction through all or a significant portion of its range.

SR (State Rare) - Long-established breeding or wintering species quantitatively documented to be declining, facing extirpation from the Cormonwealth, and considered likely to disappear without special action.

SL (State Local) - Long-established breeding or wintering species in the Commonweal th that are restricted to very limited areas. A few species (SLA), which are widespread but nowhere frequent are also included.

\section{RHODE ISLAND}

Legal protection of amphibian and reptile species is afforded by:

Rhode Island Department of Environmental Management, Division of Fish and Wildlife. Rhode Island Wildlife Laws.

$P$ (Protected) - Protected under State wildlife laws, special rules and regulations, provision in Section 21-9 of the General Laws of the State of Rhode Island. 

Rhode Island National Heritage Program of 1980 developed a list of the species for consideration as an unofficial list including species to be considered in planning:

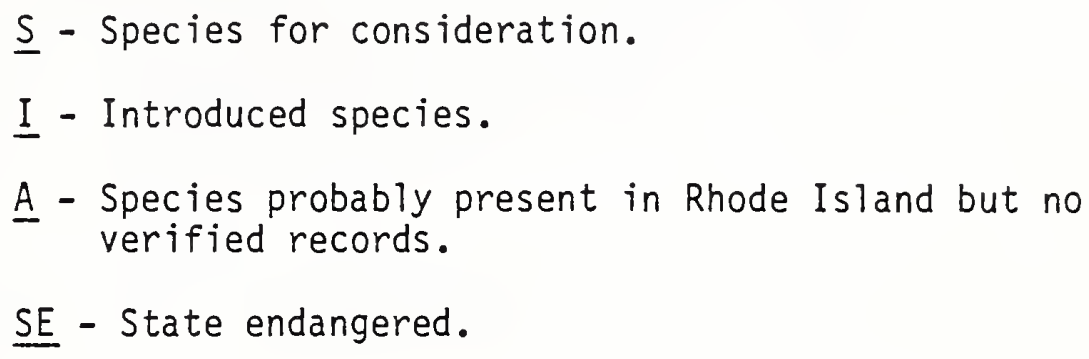

NEW YORK

Certain species are legally protected:

New York State Department of Environmental Conservation. 1970. Traffic in endangered species of fish and wildiife. Section 182.1.

E (State Endangered) - Species threatened with extinction as listed in the Federal Register.

New York Environmental Conservation Law, Section 11-0103(c).

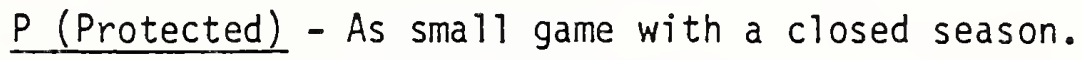

Endangered Species Unit listing of species with unofficial classification.

SC (Special Concern) - Species probable candidates for inclusion on official state listing, or species not yet endangered or threatened which should be monitored. 

Landry, J. L., L. P. Hirsch, and E. R. McCaffrey. 1979. A rating system for threatened and endangered species of wildlife. N.Y. Fish and Game Journal $26(1): 11-21$.

T (Threatened) - Species whose populations in New York are. subject to a significant threat from known or unknown causes, but which face little danger of extirpation within the foreseeable future if certain actions are taken and maintained.

\section{NEW JERSEY}

All species listed are protected under New Jersey Wildlife Law 23:1A-6, 1973.

New Jersey Department of Environmental Protection, Division of Fish, Game and Shellfisheries.

1979. Endangered, threatened, peripheral, declining, undetermined and extirpated wildlife species in New Jersey, official list. Endangered and Nongame Species Project. Trenton. 12pp.

$E$ (Endangered) - An endangered species is one whose prospects for survival within the State are in immediate danger due to one or many factors--a loss of or change in habitat, over exploitation, predation, competition, disease. An endangered species requires immediate assistance or extinction will probably follow.

T (Threatened) - May become endangered if conditions surrounding the species begin to or continue to deteriorate.

$U$ (Undetermined) - A species about which there is not enough information available to determine the status.

D (Declining) - A species which has exhibited a continued decline in population numbers over the years. 

R (State Rare Taxon) - Populations and/or individuals occurring in very low numbers relative to other similar taxa in the State, although common or regularly occurring throughout much of their ranges. They may be found in a restricted geographic region or occur sparsely over a wider area. Although rare, populations are apparently stable. Also included in this category are migrant or wintering birds that regularly occur in Connecticut, although are rare throughout a 11 or much of their range.

I (Taxon of Indeterminate Status) - One whose population status within the State is unclear or unknown at this time; further investigation and additional information is necessary. This category includes those taxa that have not been collected or observed in a great many years and which may now be extinct in the State.

\section{NEW HAMPSHIRE}

Species unofficially listed for future consideration:

New Hampshire Fish and Game Department.

1980. New Hampshire endangered and threatened species list. 1p.

$$
\begin{aligned}
& \text { Species of Concern: } \\
& \underline{R} \text { - Rare } \\
& \underline{U} \text { - Status Undetermined }
\end{aligned}
$$

\section{$\underline{\text { VERMONT }}$}

No list of endangered herpetofauna developed to date. 
. 
屏

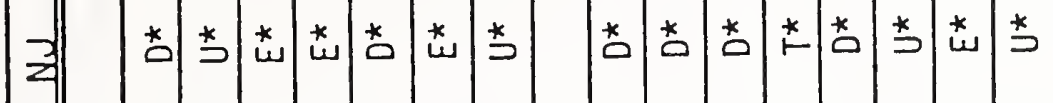

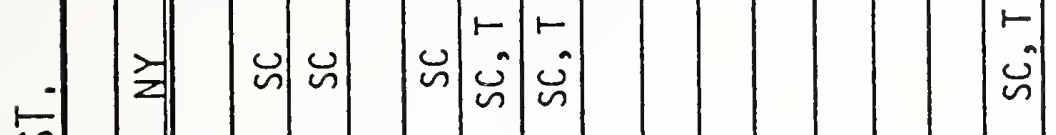

勿

퐆

웅 aㅖn< $\backsim<n$

$n<$

$\sim$

岸

国跑

$\simeq \propto-\propto$

$\propto$

3.

氛䒺崖

$* * * * *$

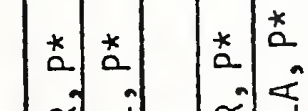

की जी की की

$\propto-\infty \propto$

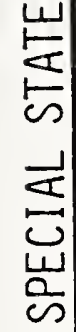

营

5

* $*$

命㐫

*

*

$\star n$

¿் 



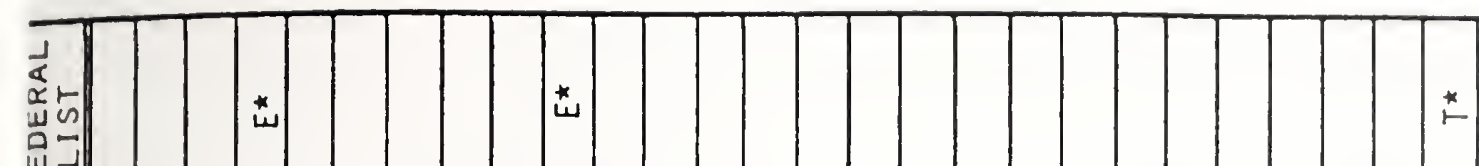

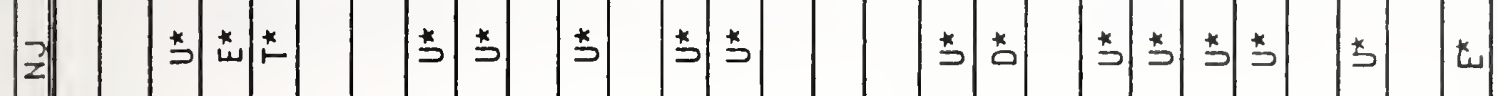

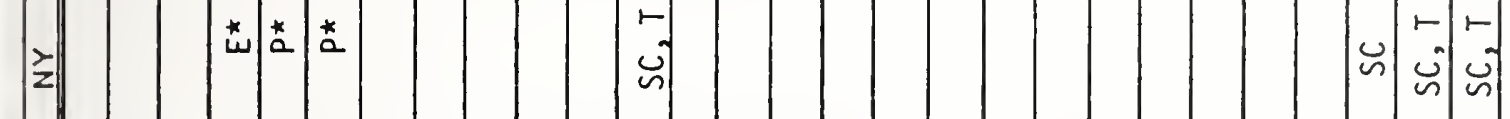

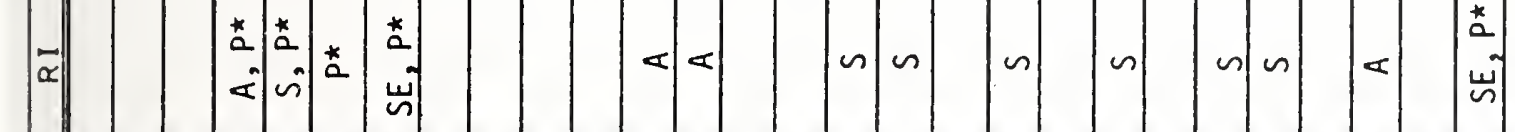

0
0

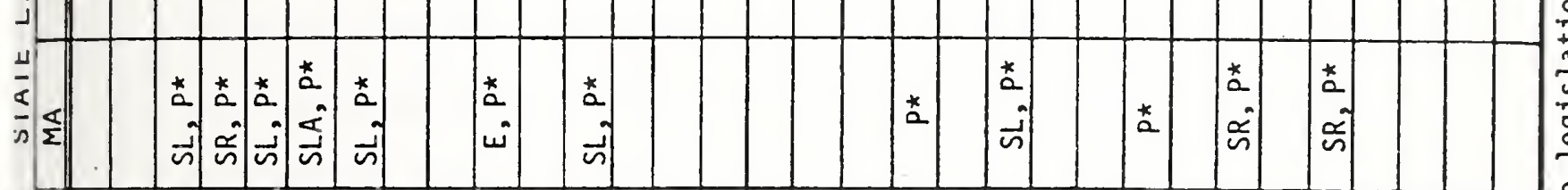

5

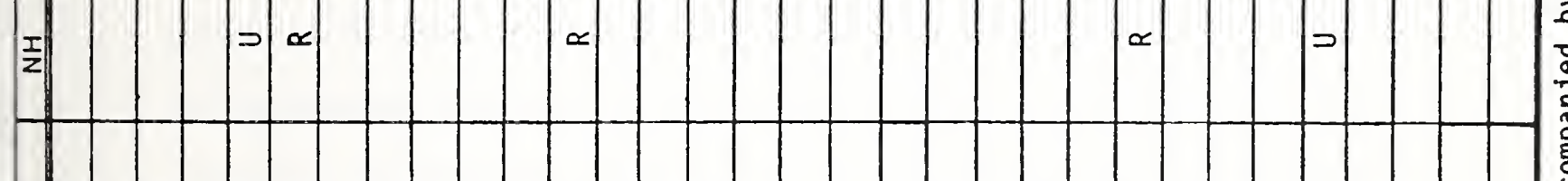

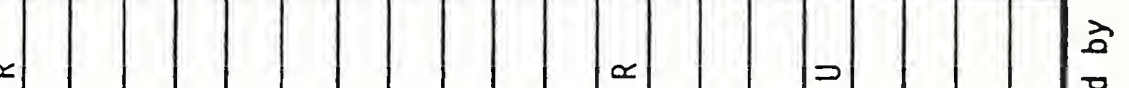

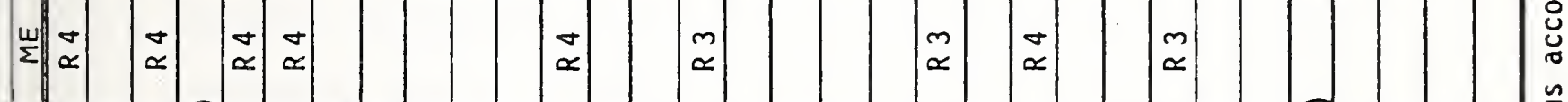

(

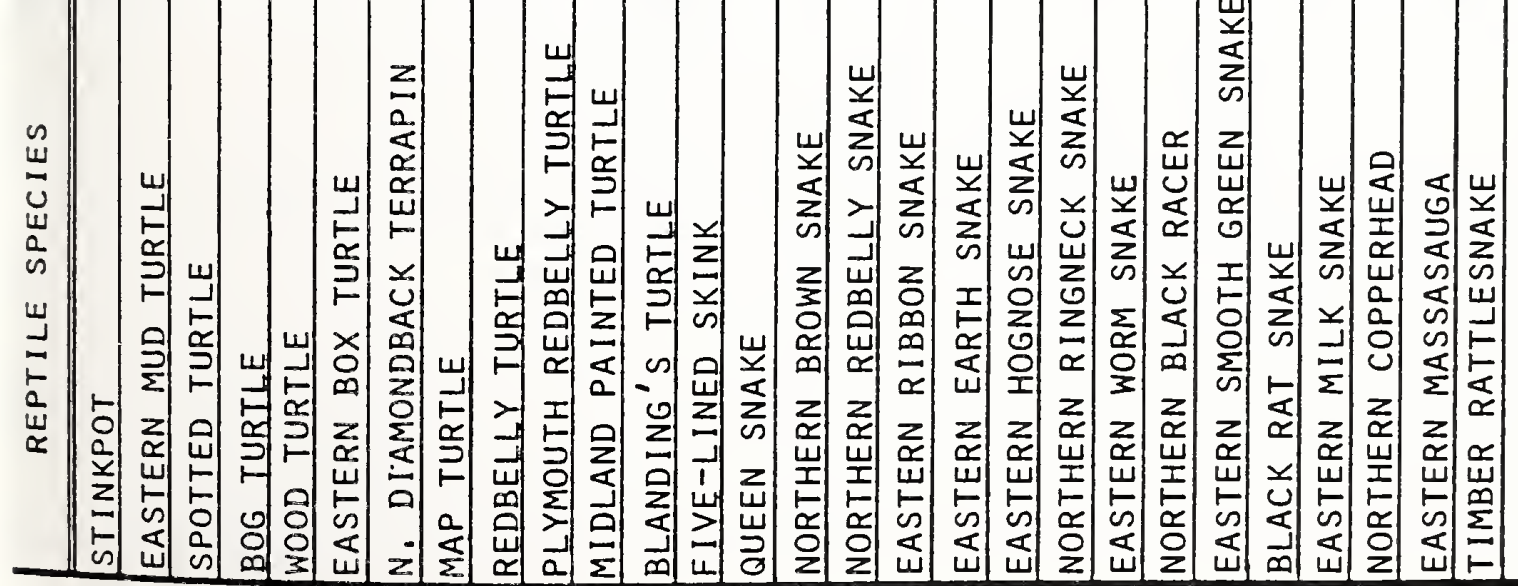





\section{AMPHIBIAN AND REPTILE HABITAT RELATIONSHIPS}

Tables 4 and 5 present habitat associations for amphibians and reptiles whose ranges occur in the New England Planning Area. Associations are shown for timbered communities and age classes and for nontimbered communities, especially wetland types. Most species in particular the amphibians, are more strongly associated with wetland types or other microhabitats than they are with the surrounding forest community type.

However, because forest management practices are usually prescribed by timber type, these associations with forest communities are potentially very important. This is the first attempt to describe herpetofaunal habitats in this way, and the habitat association must therefore be regarded as preliminary. As research progresses, this information can be refined.

The following tables summarize the uses of timbered and nontimbered habitat for feeding and reproduction, and indiciate primary habitat and special habitat needs.

Note that the tabular information should be used in conjunction with the habitat descriptions provided in the species accounts, especially where special habitat requirements are noted. 

AMPHIBIANS

$\underline{\text { ASPEN - Regenerating }}$
N. Ringneck Snake

N. Black Racer

E. Milk Snake

E. Box Turtle Wood Turtle

Bog Turtle

\section{ASPEN - Young}

Redback Salamander Jefferson Salamander Wood Frog

$\underline{\text { ASPEN - Mature }}$

Jefferson Salamander
Bog Turtle Wood Turtle $E$. Box Turtle Five-Tined Skink N. Coal Skink N. Redbelly Snake

N. Ringneck Snake

E. Worm Snake

N. Black Racer

E. Smooth Green Snake

E. Milk Snake

E. Massasaliga

N. Brown Snake

Bog Turtle Wood Turtle E. Box Turtie

Five-lined Skink

N. Coal Skink

N. Brown Snake

N. Redbeliy Snake

N. Ringneck Snake

E. Worm Snake

N. Black Racer

E. Smooth Green Snake

E. Milk Snake

E. Massasauga 

ASPEN - Old

Jefferson Salamander

Bog Turtle Wood Turtle E. Box Turtle Five-lined Skink

N. Coal Skink

N. Brown Snake

N. Redbelly Snake

N. Ringneck Snake

E. Worm Snake

N. Black Racer

E. Smooth Green Snake

E. Milk Snake

E. Massasauga

BIRCH - Regenerating

Bull frog

Green Frog

Bog Turtle Wood Turtle E. Box Turtle Five-lined Skink N. Ringneck Snake

N. Black Racer

BIRCH - Young

Jefferson Salamander Bog Turtle Bull frog

Green Frog Wood Turtle E. Box Turtle Five-lined Skink

N. Brown Snake

E. Garter Snake

N. Ringneck Snake

E. Worm Snake

N. Black Racer

$\underline{B I R C H}$ - Mature

Jefferson Salamander

Bog Turtle Redback Salamander Wood Turtle Bull frog E. Box Turtle Green Frog Five-lined Skink 


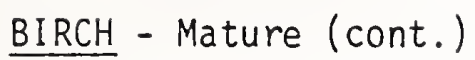
N. Brown Snake
N. Ringneck Snake
E. Worm Snake
N. Black Racer
E. Smooth Green Snake

$\underline{B I R C H}-01 d$

Jefferson Salamander

Bullfrog

Green Frog
Bog Turtle Wood Turtle Box Turtle Five-lined Skink

N. Brown Snake

N. Ringneck Snake

E. Worm Snake

N. Black Racer

E. Smooth Green Snake

NORTHERN HARDWOOD-HEMLOCK - Regenerating

Spotted Salamander

E. Tiger Salamander

Red-spotted Newt

Mountain Dusky Salamander

Four-toed Salamander

N. Two-lined Salamander

Bullfrog

Green Frog

Pickerel Frog
Wood Turtle

Box Turtle

Five-lined Skink

N. Coal Skink

E. Garter Snake

N. Ringneck Snake

N. Black Racer

E. Smooth Green Snake

E. Milk Snake

NORTHERN HARDWOOD-HEMLOCK - Young

Jefferson Salamander

Tremblay's Salamander

Blue-spotted Salamander

Spotted Salamander

E. Tiger Salamander

Red-spotted Newt

Mountain Dusky Salamander

Redback Salamander

Slimy Salamander
Wood Turtle

E. Box Turtle

Five-lined Skink

N. Coal Skink

N. Brown Snake

N. Redbelly Snake

E. Garter Snake

E. Ribbon Snake

N. Ringneck Snake 

NORTHERN HARDWOOD-HEMLOCK - Young (cont.)

Four-toed Salamander

N.Spring Salamander

N. Red Salamander

N. Two-lined Salamander

Bullfrog

Green Frog

Mink Frog

Wood Frog

Pickerel Frog

NORTHERN HARDWOOD-HEMLOCK - Mature

Jefferson Salamander

Tremblay's Salamander

Blue-spotted Salamander

Spotted Salamander

E. Tiger Salamander

Red-spotted Newt

N. Dusky Salamander

Mountain Dusky Salamander

Redback Salamander

Sl imy Salamander

Four-toed Salamander

N. Spring Salamander

N. Red Salamander

N. Two-lined Salamander

American Toad

Bul 17 frog

Green Frog

Mink Frog

Wood Frog

N. Leopard Frog

S. Leopard Frog

Pickerel Frog

NORTHERN HARDWOOD-HEMLOCK - 01d

Jefferson Salamander

Tremblay's Salamander

Blue-spotted Salamander

Spotted Salamander

E. Tiger Salamander
N. Black Racer

E. Smooth Green Snake

E. Milk Snake

Timber Rattlesnake
Common Snapping Turtle Wood Turtle

E. Box Turtle

Five-lined Skink

N. Coal Skink

N. Brown Snake

N. Redbelly Snake

E. Garter Snake

E. Ribbon Snake

N. Black Racer

E. Smooth Green Snake

E. Milk Snake

Timber Rattlesnake
Common Snapping Turtle Wood Turtle

E. Box Turtle

Five-lined Skink

N. Coal Skink 

NORTHERN HARDWOOD-HEMLOCK - 01d (cont.)

Red-spotted Newt

N. Dusky Salamander

Mountain Dusky Salamander

Redback Salamander

Slimy Salamander

Four-toed Salamander

N. Spring Salamander

N. Red Salamander

N. Two-lined Salamander

Bullfrog

Green Frog

Mink Frog

Wood Frog

N. Leopard Frog

$S$. Leopard Frog

Pickerel Frog

NORTHERN HARDWOOD-HEMLOCK - All Age

Jefferson Salamander

Tremblay's Salamander

Blue-spotted Salamander

Spotted Salamander

$E$. Tiger Sal amander

Red-spotted Newt

N. Dusky Sal amander

Mountain Dusky Salamander

Redback Salamander

Slimy Salamander

Four-toed Salamander

N. Spring Salamander

$N$. Red Salamander

N. Two-lined Salamander

Bullfrog

Green Frog

Mink Frog

Wood Frog

N. Leopard Frog

S. Leopard Frog

Pickerel Frog
N. Brown Snake

N. Redbelly Snake

E. Garter Snake

E. Ribbon Snake

N. Black Racer

E. Smooth Green Snake

E. Milk Snake

Timber Rattlesnake
Common Snapping Turtle Wood Turtle

E. Box Turtle

Five-lined Skink

N. Coal Skink

N. Brown Snake

N. Redbelly Snake

E. Garter Snake

E. Ribbon Snake

N. Black Racer

E. Milk Snake

Timber Rattlesnake 

SWAMP HARDWOODS - Regenerating

Marbled Salamander Jefferson Salamander Spotted Salamander $E$. Tiger Sal amander Red-spotted Newt Four-toed Sal amander Gray Treefrog

Bullfrog

Green Frog

Mink Frog
Common Snapping Turtle Bog Turtle Wood Turtle E. Box Turtle Five-lined Skink N. Coal Skink Queen Snake E. Garter Snake Shorthead Garter Snake E. Hognose Snake

N. Ringneck Snake

E. Worm Snake

N. Black Racer

Black Rat Snake

E. Milk Snake

N. Water Snake

SWAMP HAROWOODS - Young

Marbled Sal amander Jefferson Salamander Tremblay's Salamander Spotted Sal amander E. Tiger Salamander Red-spotted Newt $N$. Dusky Salamander Mountain Dusky Salamander Redback Salamander Sl imy Salamander Four-toed Salamander N. Spring Salamander

$N$. Red Salamander

$N$. Two-l ined Salamander

American Toad

Fowler's Toad

N. Spring Peeper

Gray Treefrog

W. Chorus Frog

Upland Chorus Frog

Bullfrog

Green Frog

Mink Frog

N. Leopard Frog

S. Leopard Frog

Pickerel Frog

Wood Frog
Common Snapping Turtle Bog Turtle Wood Turtle

E. Box Turtle

Five-lined Skink

N. Coal Skink

$N$. Water Snake

Queen Snake

N. Brown Snake

N. Redbelly Snake

Shorthead Garter Snake

E. Ribbon Snake

E. Hognose Snake

N. Ringneck Snake

E. Worm Snake

N. Black Racer

E. Smooth Green Snake

Black Rat Snake

E. Milk Snake

N. Copperhead

E. Massasauga

Timber Rattlesnake Rough Green Snake 

SWAMP HARDWOODS - Mature

E. Tiger Salamander

Marbled Salamander

Jefferson Salamander

Tremblay's Salamander

Spotted Salamander

Red-spotted Newt

N. Dusky Salamander

Mountain Dusky Salamander

Redback Salamander

Slimy Salamander

Four-toed Salamander

N. Spring Salamander

N. Red Salamander

N. Two-l ined Salamander

American Toad

Fowler's Toad

N. Spring Peeper

W. Chorus Frog

Upland Chorus Frog

Bullfrog

Green Frog

Mink Frog

Wood Frog

N. Leopard Frog

S. Leopard Frog

Pickerel Frog

SWAMP HARDWOODS - 01d

Marbled Salamander

Jefferson Salamander

Tremblay's Salamander

Spotted Salamander

E. Tiger Salamander

Red-spotted Newt

N. Dusky Salamander

Mountain Dusky Salamander

Redback Salamander

ST imy Salamander

Four-toed Salamander

N. Spring Salamander

N. Red Salamander

N. Two-lined Salamander

N. Spring Peeper
E. Painted Turtle

Common Snapping Turtle Bog Turtle

Wood Turtle

E. Box Turtle

Five-l ined Skink

N. Coal Skink

N. Water Snake

Queen Snake

N. Brown Snake

N. Redbelly Snake

E. Garter Snake

E. Ribbon Snake

E. Hognose Snake

N. Ringneck Snake

E. Worm Snake

N. Black Racer

E. Smooth Green Snake

Black Rat Snake

E. Milk Snake

N. Copperhead

E. Massasauga

Timber Rattlesnake

Shorthead Garter Snake

Common Snapping Turtle Bog Turtle Wood Turtle

E. Box Turtle

E. Painted Turtle

Five-lined Skink

N. Coal Skink

N. Water Snake

Queen Snake

N. Brown Snake

N. Redbelly Snake

Shorthead Garter Snake

E. Ribbon Snake

E. Hognose Snake

N. Ringneck Snake 

SWAMP HARDWOODS - 01d (cont.)

\author{
W. Chorus Frog \\ Upland Chorus Frog \\ Bullfrog \\ Green Frog \\ Mink Frog \\ Wood Frog \\ N. Leopard Frog \\ S. Leopard Frog \\ Pickerel Frog
}

NORTHERN RED OAK - Regenerating

Green Frog

NORTHERN RED OAK - Young

Green Frog

NORTHERN RED OAK - Mature

Redback Salamander

Green Frog

Wood Frog
E. Worm Snake

N. Black Racer

E. Smooth Green Snake

Black Rat Snake

E. Milk Snake

N. Copperhead

E. Massasauga

Timber Rattlesnake
Wood Turtle

E. Box Turtle

N. Coal Skink

N. Ringneck Snake

N. Black Racer

E. Smooth Green Snake

Black Rat Snake
Wood Turtle

E. Box Turtle

$N$. Fence Lizard

N. Coal Skink

N. Redbelly Snake

E. Earth Snake

E. Hognose Snake

N. Ringneck Snake

N. Black Racer

E. Smooth Green Snake

Black Rat Snake

Timber Rattlesnake
Wood Turtle

E. Box Turtle

$N$. Fence Lizard 

NORTHERN RED OAK - Mature (cont.)
N. Coal Skink
N. Redbelly Snake
E. Earth Snake
E. Hognose Snake
N. Black Racer
E. Smooth Green Snake
Black Rat Snake
N. Copperhead

NORTHERN RED OAK - OId Age

E. Spadefoot

American Toad

Green Frog
Wood Turtle
Box Turtle
$N$. Fence Lizard
N. Coal Skink
N. Redbelly Snake
E. Earth Snake
E. Hognose Snake
N. Black Racer
E. Smooth Green Snake
Black Rat Snake
N. Copperhead

OAK-PINE - Regenerating

N. Dusky Salamander

$N$. Two-l ined Salamander

American Toad

Fowler's Toad

Gray Treefrog

New Jersey Chorus Frog

Green Frog

Wood Frog

OAK-PINE - Young

Spotted Salamander

Red-spotted Newt

Redback Salamander

N. Two-lined Salamander
Wood Turtle

E. Box Turtle

N. Coal Skink

N. Black Racer

Black Rat Snake

E. Milk Snake
Wood Turtle

Box Turtle

E. Painted Turtle

$N$. Fence Lizard 

OAK-PINE - Young (cont.)

E. Spadefoot

American Toad

Fowler's Toad

Gray Treefrog

New Jersey Chorus Frog

Green Frog
N. Coal Skink

N. Redbelly Snake

E. Earth Snake

E. Hognose Snake

N. Black Racer

Black Rat Snake

E. Milk Snake

N. Copperhead

Timber Rattlesnake

OAK-PINE - Mature

Jefferson Salamander

Spotted Salamander

Red-spotted Newt

N. Dusky Salamander

Mountain Dusky Salamander

Redback Salamander

Sl imy Salamander

N. Two-l ined Salamander

E. Spadefoot

American Toad

Fowler's Toad

N. Spring Peeper

New Jersey Chorus Frog

Green Frog

Wood Frog

OAK-PINE - 01d Age

Spotted Salamander

Red-spotted Newt

N. Two-l ined Salamander

E. Spadefoot

American Toad

Fowler's Toad

Green Frog
Wood Turtle

E. Box Turtle

E. Painted Turtle

$N$. Fence Lizard

N. Coal Skink

N. Redbelly Snake

E. Earth Snake

E. Hognose Snake

N. Black Racer

Black Rat Snake

E. Milk Snake

N. Copperhead

Timber Rattlesnake
Wood Turtle

E. Box Turtle

E. Painted Turtle

N. Fence Lizard

N. Coal Skink

N. Redbelly Snake

E. Earth Snake

E. Hognose Snake

N. Black Racer

Black Racer

E. Milk Snake

N. Copperhead 

BALSAM FIR - Regenerating

Wood Turtle

BALSAM FIR - Young

Redback Salamander Wood Turtle

American Toad

N. Brown Snake

Mink Frog

Wood Frog

BALSAM FIR - Mature

Redback Salamander

American Toad

Wood Turtle

N. Spring Peeper

N. Brown Snake

Mink Frog

Wood Frog

BALSAM FIR - 01d Age

Mink Frog

Wood Frog

Wood Turtle

N. Brown Snake

PINE - Regenerating

E. Tiger Salamander

Mountain Dusky Salamander

Redback Salamander

Wood Turtle

E. Box Turtle

N. Black Racer

PINE - Young

E. Tiger Salamander

Mountain Dusky Salamander

Redback Salamander

American Toad

Wood Turtle

E. Box Turtle

N. Redbelly Snake

E. Ribbon Snake 

PINE - Young (cont.)

New Jersey Chorus Frog

E. Earth Snake

E. Hognose Snake

N. Black Racer

E. Milk Snake

N. Copperhead

PINE - Mature

E. Tiger Salamander

Mountain Dusky Salamander

Redback Salamander

American Toad

New Jersey Chorus Frog

Wood Turtle

E. Box Turtle

$N$. Fence Lizard

N. Redbelly Snake

E. Ribbon Snake

E. Earth Snake

E. Hognose Snake

N. Black Racer

E. Milk Snake

N. Copperhead

PINE - 01d Age

E. Tiger Salamander

Redback Salamander

New Jersey Chorus Frog
Wood Turtle

E. Box Turtle

$N$. Fence Lizard

N. Redbelly Snake

E. Ribbon Snake

E. Earth Snake

E. Hognose Snake

N. Black Racer

E. Milk Snake

N. Copperhead

SPRUCE-FIR - Regenerating

Spotted Salamander

Bog Turtle

E. Tiger Salamander

Wood Turtle

$N$. Red Salamander

Green Frog

Wood Frog

N. Leopard Frog 

SPRUCE-FIR - Young

E. Tiger Salamander

Redback Salamander

Four-toed Salamander

N. Spring Salamander

$N$. Red Salamander

American Toad

N. Spring Peeper

W. Chorus Frog

Green Frog

Mink Frog

Wood Frog

N. Leopard Frog

SPRUCE-FIR - Mature

E. Tiger Salamander

Redback Salamander

Four-toed Salamander

N. Spring Salamander

$N$. Red Salamander

Spotted Salamander

American Toad

N. Spring Peeper

W. Chorus Frog

Green Frog

Mink Frog

Wood Frog

N. Leopard Frog

SPRUCE-FIR - 01d Age

E. Tiger Salamander

Redback Salamander

Four-toed Salamander

N. Spring Salamander

N. Red Salamander

N. Spring Peeper

W. Chorus Frog

Green Frog

Mink Frog

Wood Frog

N. Leopard Frog
Bog Turtle Wood Turtle

N. Brown Snake
Bog Turtle

Wood Turtle

N. Brown Snake
Bog Turtle Wood Turtle

N. Brown Snake 

SPRUCE - Regenerating

Wood Turtle

SPRUCE - Young

Four-toed Salamander Wood Turtle

$N$. Spring Salamander N. Brown Snake

American Toad

W. Chorus Frog

Bullfrog

Mink Frog

Wood Frog

SPRUCE - Mature

Four-toed Salamander Wood Turtle

N. Spring Salamander

N. Brown Snake

W. Chorus Frog

Mink Frog

Wood Frog

SPRUCE - 01d Age

Four-toed Salamander

N. Spring Salamander

Wood Turtle

W. Chorus Frog

Mink Frog

Wood Frog

HEMLOCK - Regenerating

N. Brown Snake

Bog Turtle Wood Turtle

HEMLOCK - Young

Redback Salamander N. Spring Salamander

American Toad

Bog Turtle Wood Turtle

$N$. Redbelly Snake 

HEMLOCK - Young (cont.)

N. Spring Peeper

Bullfrog

HEMLOCK - Mature

Red-spotted Newt

N. Dusky Salamander

Redback Salamander

Slimy Salamander

E. Spadefoot

American Toad

N. Spring Peeper

Bullfrog

Wood Frog

N. Leopard Frog

HEMLOCK - 01d Age

Redback Salamander

E. Spadefoot

N. Spring Peeper

Bullfrog

Wood Frog

N. Leopard Frog
N. Ringneck Snake

N. Copperhead

Bog Turtle Wood Turtle

N. Redbelly Snake

N. Ringneck Snake

N. Copperhead
Bog Turtle Wood Turtle

$N$. Redbelly Snake

N. Ringneck Snake

N. Copperhead 



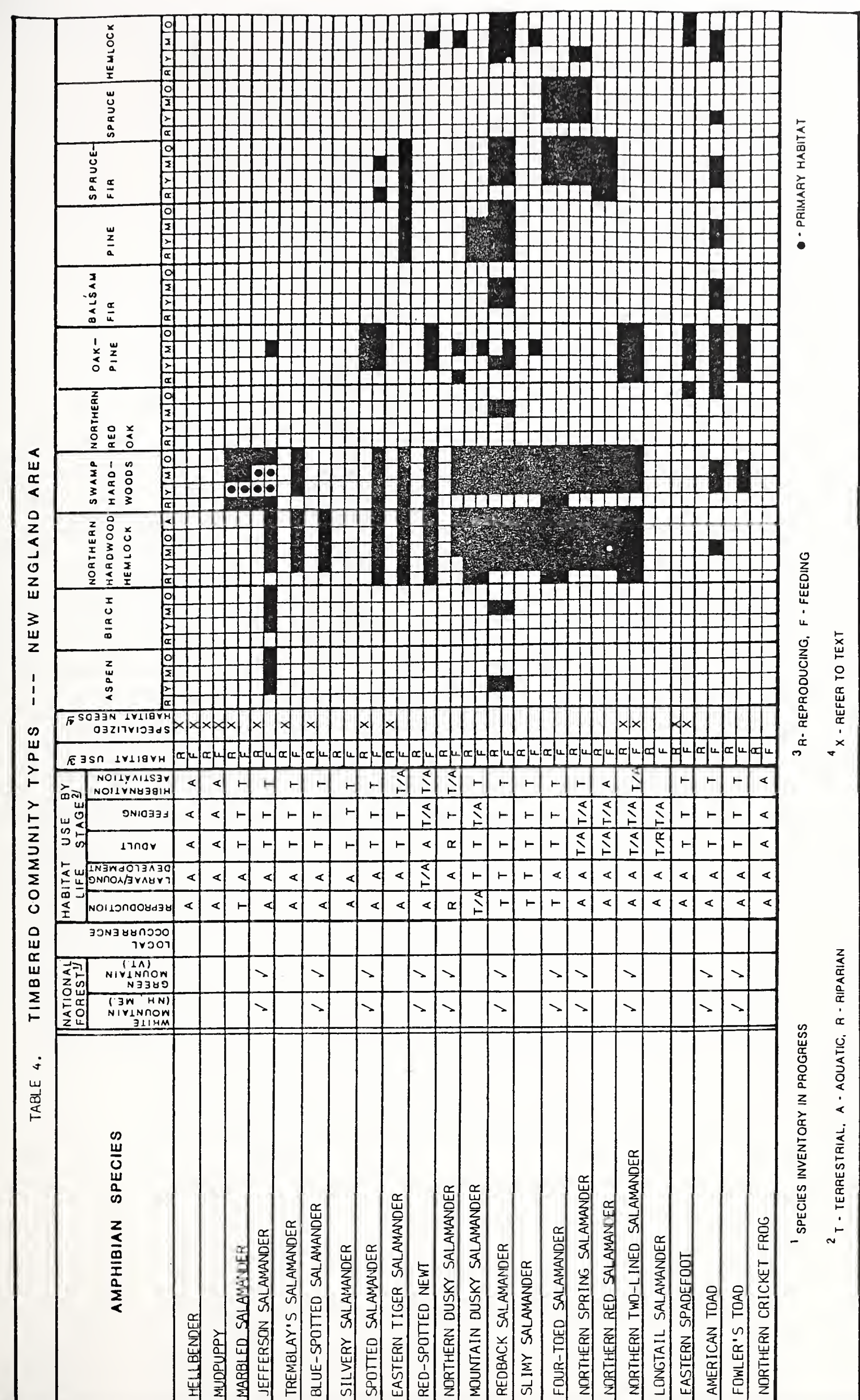












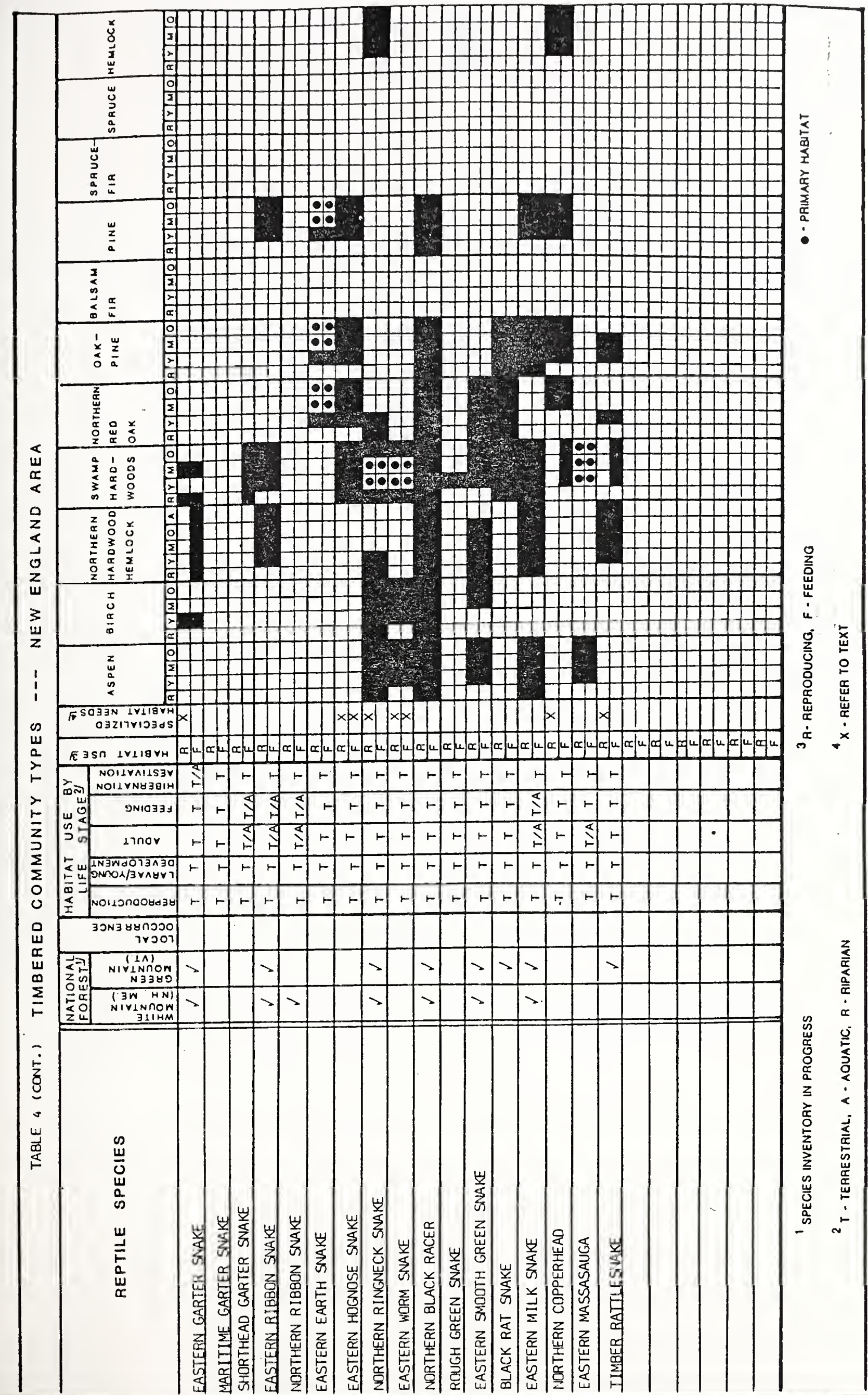





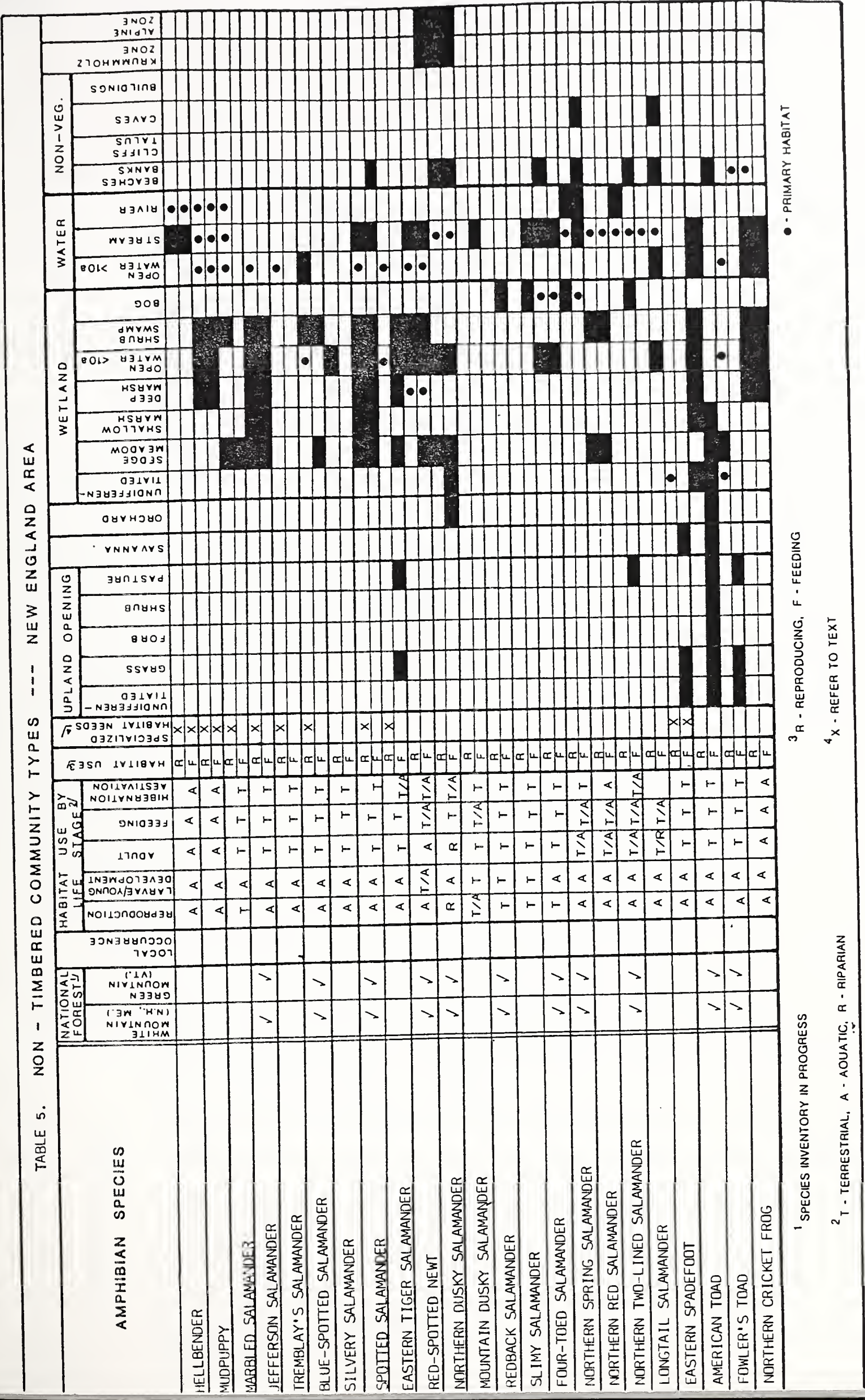





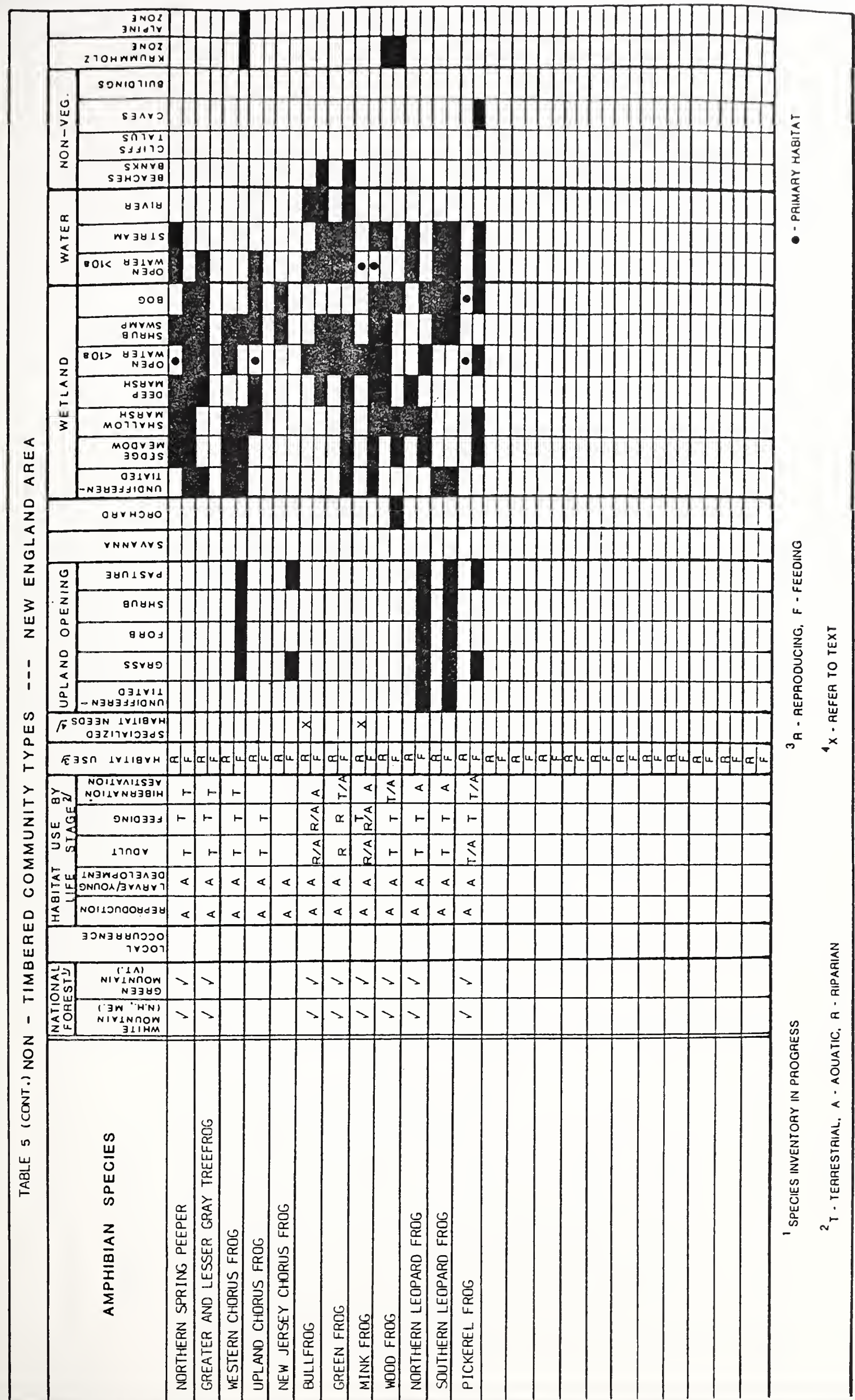






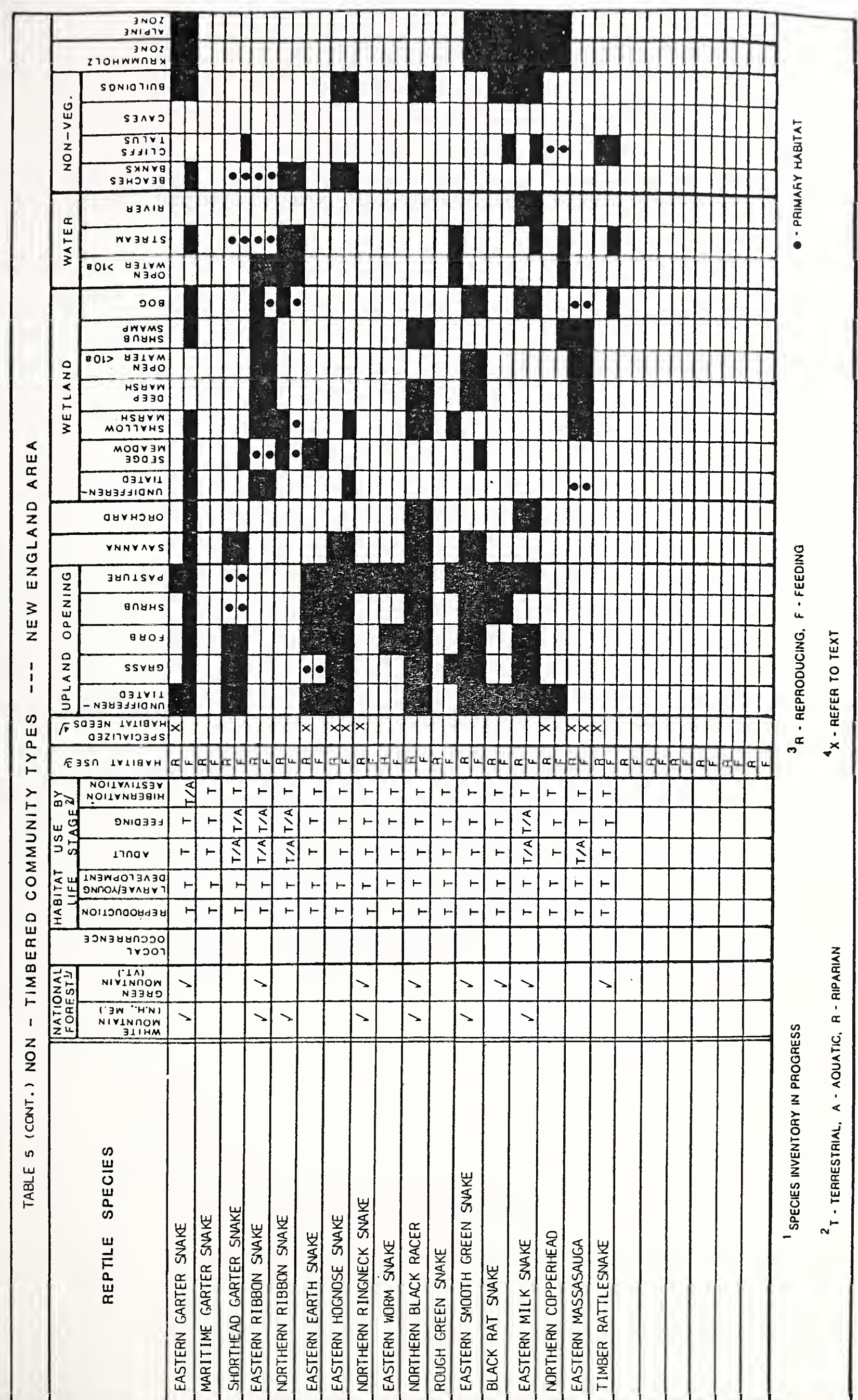





\section{NORTHEASTERN AMPHIBIANS AND REPTILES}

Caudata

Cryptobranchidae

Eastern Hellbender Cryptobranchus a. aZZeganiensis

Necturidae

Mudpuppy Nectumus m. macuZosus

Ambystomatidae

Marbled Salamander Ambystoma opacum

Jefferson Salamander Ambystoma jeffersonianum

Tremblay's Salamander Ambystoma tremblayi

Blue-spotted Salamander Ambystoma Zaterale

Silvery Salamander Ambystoma platineum

Spotted Salamander Ambystoma maculatum

Eastern Tiger Salamander Ambystoma t. tigrinum

Sa lamandridae

Red-spotted Newt Notophthalmus v. vimidescens

Plethodontidae

Northern Dusky Salamander Desmognathus $f$. fuscus

Mountain Dusky Salamander Desmognathus ochrophaeus

Redback Salamander Plethodon cinereus

Slimy Salamander Plethodon g. glutinosus

Four-toed Salamander Hemidactylizon scutatum

Northern Spring Salamander Gyminophilus p. porphymiticus

Northern Red Salamander Pseudotriton $r$. mber

Northern Two-lined Salamander Eurycea b. bis Zineata

Longtail Salamander Eurycea Z. Zongicauda

Anura

Pelobatidae

Eastern Spadefoot Scaphiopus h. holbrooki

Bufonidae

American Toad Bufo a. americanus

Fowler's Toad Bufo woodhousei fowleri 

Hy 1 idae

Northern Cricket Frog Acris c. crepitons

Northern Spring Peeper Hyla c. cmicifer

Greater and Lesser Gray Treefrog Hyla $v$. versicolor

Hyla v. chrysoscelis

Western Chorus Frog Pseudacris t. triseriata

Upland Chorus Frog Pseudacris triseriata feriamum

New Jersey Chorus Frog Pseudacmis triseriata kalmi

Ranidae

Bullfrog Rana catesbeiana

Green Frog Rana clamitans melanota

Mink Frog Rana septentrionalis

Wood Frog Rana sylvatica

Northern Leopard Frog Rana pipiens

Southern Leopard Frog Rana sphenocephala

Pickerel Frog Rana palustris

Testudines

Che lydridae

Common Snapping Turtle Chelydra serpentina

Kinosternidae

Stinkpot Sternothems odoratus

Eastern Mud Turtle Kinostemon s. submbmom

Emydidae

Spotted Turtle Clemmys guttata

Bog Turtle Clemms muhlenbergi

Wood TurtTe Clemms insculpta

Eastern Box Turtle Terrapene c. carolina

Northern Diamondback Terrapin Malaclemys t. terrapin

Map Turtle Graptemys geographica

Red-eared Slider Chrysemys scripta elegans

Redbelly Turtle Chrysemys $r$. mbriventris

Plymouth Redbelly Turtle Chrysemys mbiventris bangsi

Eastern Painted Turtle Chrysemys p. picta

Midland Painted Turtle Chrysemys picta marginata

Blanding's Turtle Emydoidea blandingi

Trionychidae

Eastern Spiny Softshe11 Trionyx s. spiniferus 

Squamata

Lacertilia

Iguanidae

Northern Fence Lizard Sceloporus undulatus hyacinthinus

Scincidae

Five-lined Skink Eumeces fasciatus

Northern Coal Skink Eumeces a. anthracinus

Serpentes

Colubridae

Northern Water Snake Nerodia s. sipedon

Queen Snake Regina septemvittata

Northern Brown Snake Storeria d. dekayi

Northern Redbelly Snake Storeria o. occipitomaculata

Eastern Garter Snake Thamnophis s. sirtalis

Maritime Garter Snake Thamnophis sirtalis pallidula

Shorthead Garter Snake Thammophis brachystoma

Eastern Ribbon Snake Thamnophis s. scuuritus

Northern Ribbon Snake Thamophis scauritus septentrionalis

Eastern Earth Snake Virginia v. valeriae

Eastern Hognose Snake Heterodon platyrhinos

Northern Rinkneck Snake Diadophis punctatus ecwardsi

Eastern Worm Snake Camphophis a. comoenus

Northern Black Racer Coluber c. constrictor

Rough Green Snake Opheodrys aestivus

Eastern Smooth Green Snake Opheodrys v. vernalis

Black Rat Snake Elaphe o. obsoleta

Eastern Milk Snake Lompropeltis t. triangulum

Viperidae

Northern Copperhead Agkistrodon contortrix mokeson

Eastern Massasauga Sistmus c. catenatus

Timber Rattlesnake Crotalus horridus 



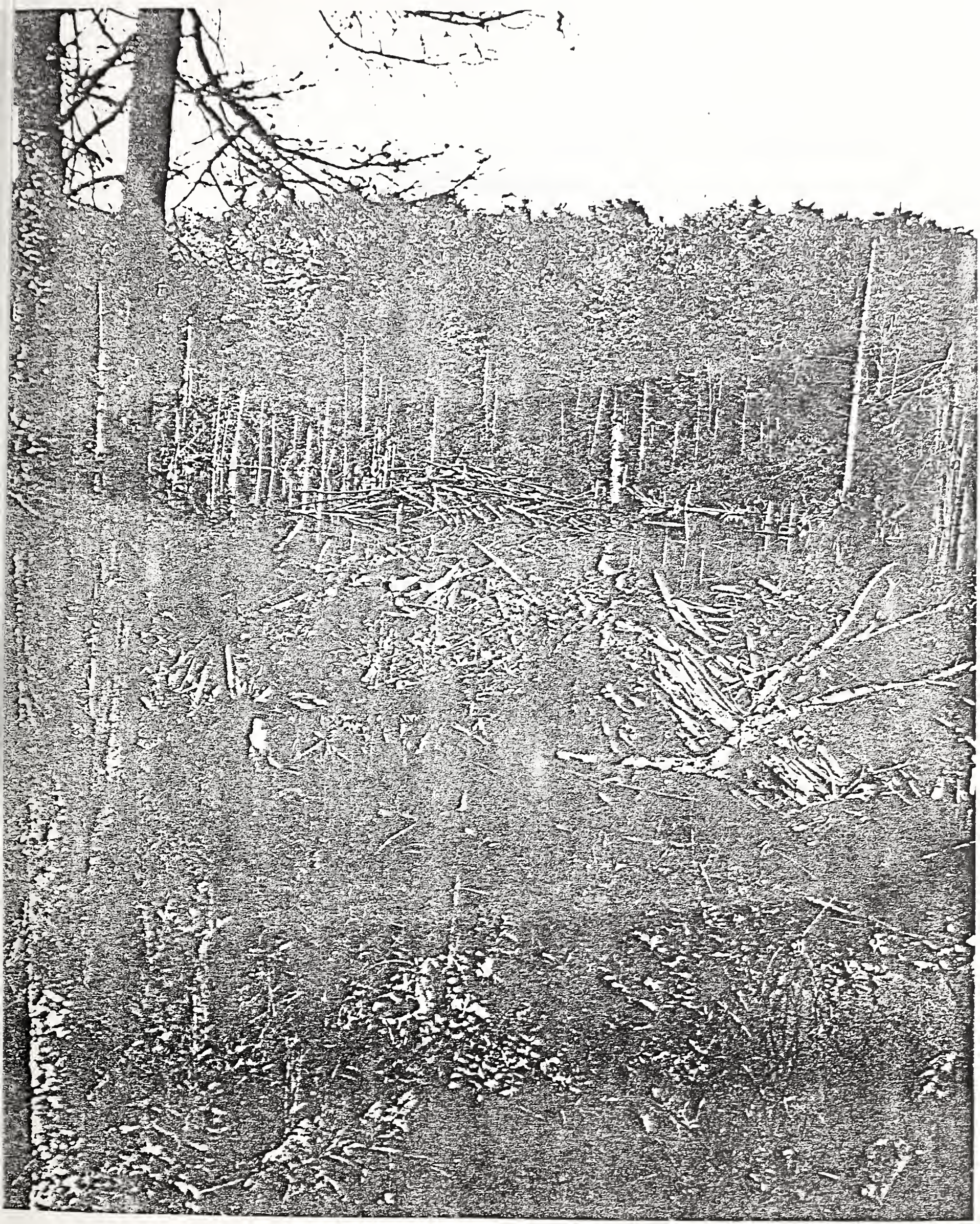





\section{AMPHIBIANS}





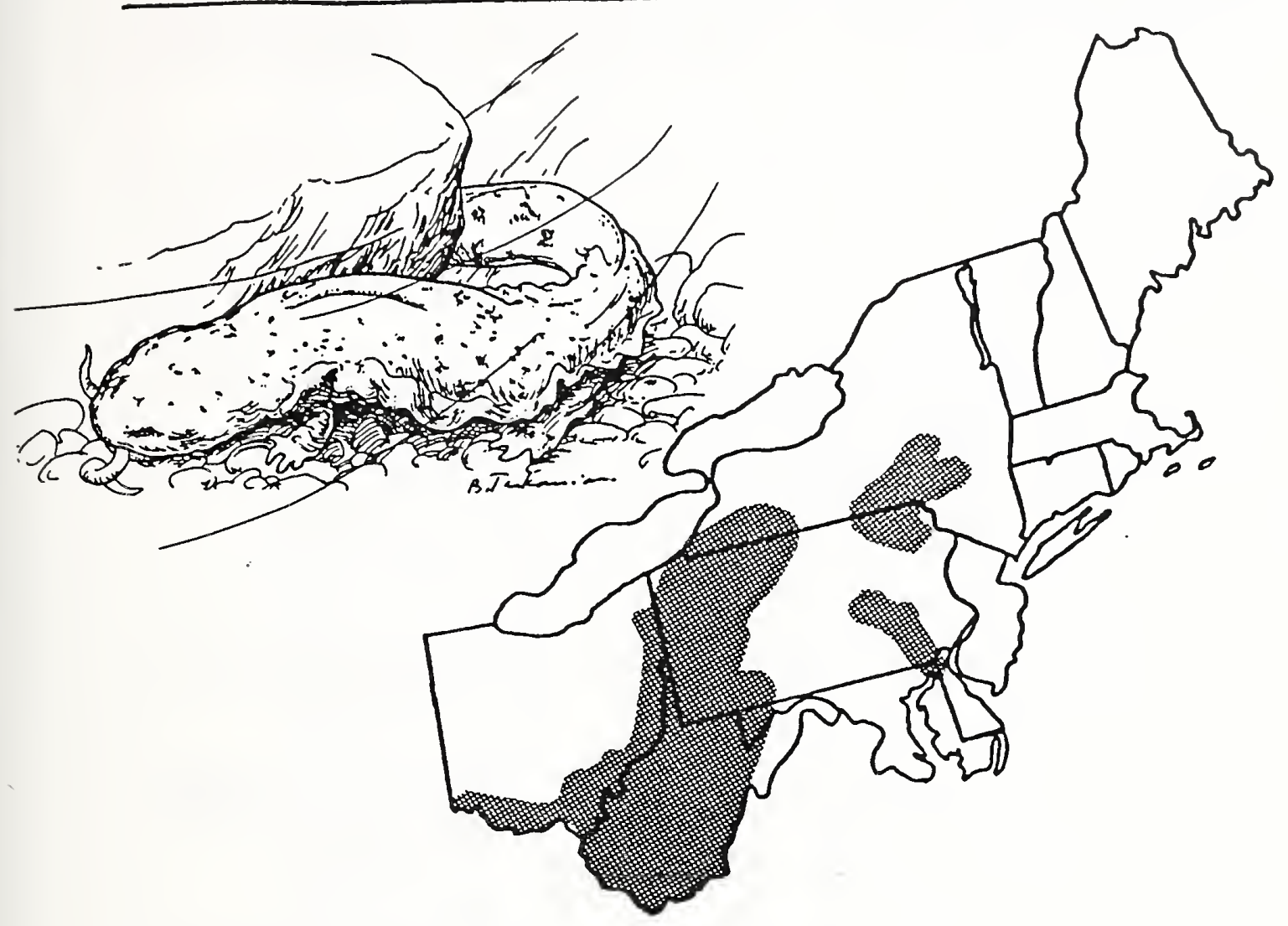

Range: Susquehanna River drainage to Chesapeake Bay, throughout the Appalachians to n. Georgia and Alabama, north to s. Illinois. Disjunct population in c. Missouri possibly extending into s.e. Kansas.

Relative Abundance in the Northeast: Uncommon.

Habitat in the Northeast: In clear, rapidly flowing rivers and permanent streams or brooks several feet deep, with rocks, logs, or other bottom objects to provide cover. Sometimes occurs in small rocky streams. Avoids silted streams (N. Green, pers. observ.).

Special Habitat Requirements: Rarely encountered in water above $20 \mathrm{C}$; this thermal barrier may partially explain restriction to upland streams (Dundee 1971:101.2).

Age/Size at Sexual Maturity: Estimated at 5 to 7 years (Minton 1972:27). Breeding Period: Late August to September (Smith 1956:32). 

Egg Deposition: August to September. The nest, a shallow excavation prepared by the male is built under large stones at the bottom of a stream or river.

No. Eggs/Mass: 300 to 450 eggs laid in long, tangled, paired strands.

Time to Hatching: 68 to 84 days, male guards nest (01iver 1955:234).

Eggs Hatch: October to November in Kentucky; larval period: 2 years.

Home Range/Movement: In Missouri, $70 \%$ of 58 individuals recaptured were less than $30 \mathrm{~m}$ from the initial tagging site, $34 \%$ were found at the tagging site and only 3 individuals were over $90 \mathrm{~m}$ away in a springfed stream (Nickerson and Mays 1973). In a Pennsylvania creek 12 to $46 \mathrm{~cm}$ deep, the average home range of 72 indjuiduals was $577 \mathrm{~m}^{2}$; $78 \%$ of ranges were smaller (median was $113 \mathrm{~m}^{2}$ ); $55 \%$ were found $10 \mathrm{~m}$ or less from the first capture site (Hillis 1969).

Food Habits/Preferences: Predatory, eating crayfish, small fish, mollusks, earthworms, insects, carrion, and sometimes their own eggs and young.

Comments: Perennially aquatic and essentially nocturnal. Available habitat has declined due to industrial pollution and lowered oxygen levels, eliminating the e. hellbender from much of its former range (Dodd 1979).

Selected References: Bishop 1947, Dundee 1971. 



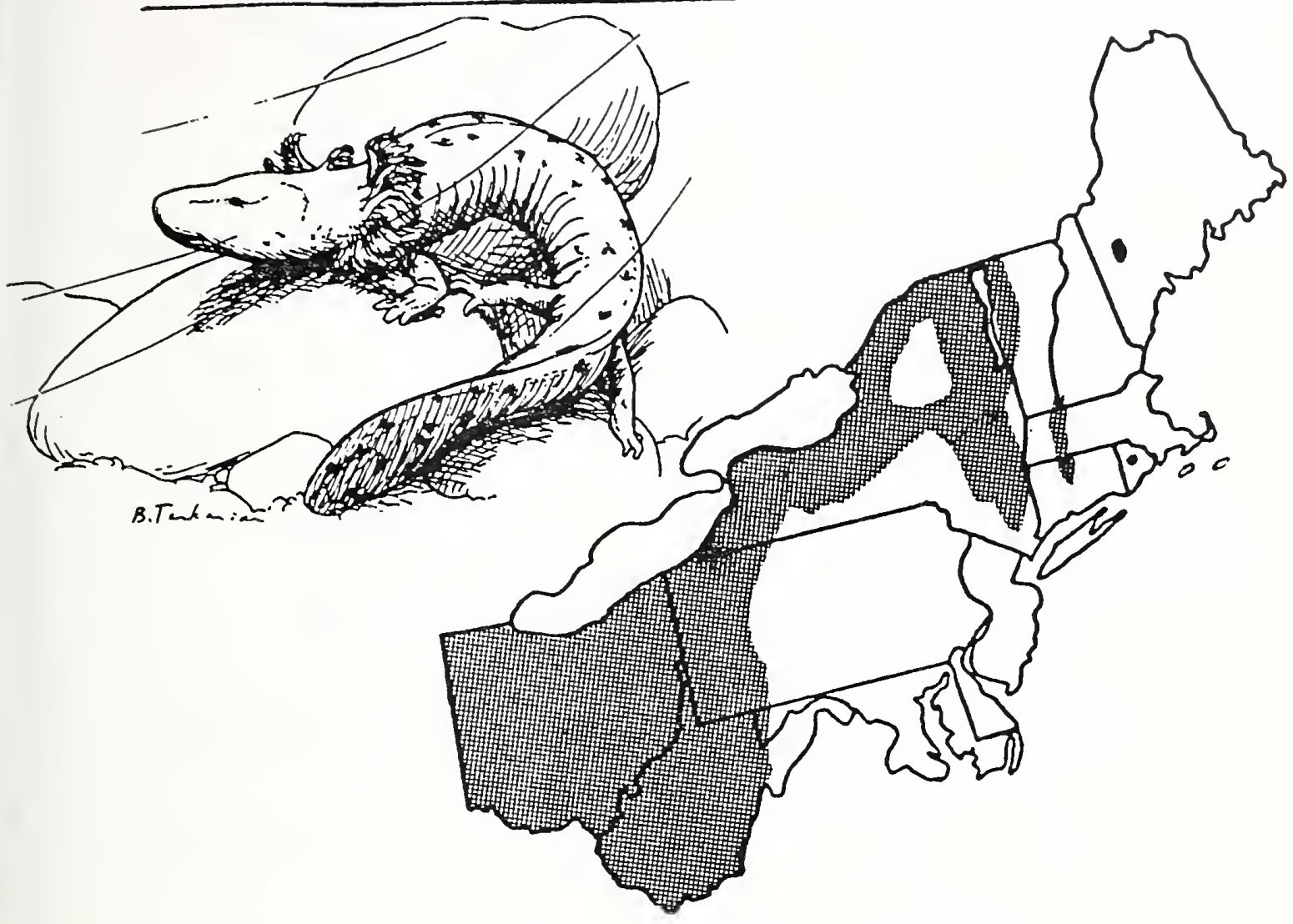

Range: St. Lawrence River west to s.e. Manitoba, south to e. Kansas and n. Alabama and through c. Pennsylvania to New York and the Lake Champlain Valley. Absent from the Adirondacks. Introduced in parts of New England.

Relative Abundance in the Northeast: Uncommon.

Habitat in the Northeast: Entirely aquatic. Clear or muddy waters of lakes, rivers, ditches, large streams. One individual found at $90 \mathrm{ft}(27.4 \mathrm{~m}$ ) in Lake Michigan (Behler and King 1979:283). Often found in submerged $\log$ piles around the bases of bridge pilings in larger rivers.

Special Habitat Requirements: Moving water.

Age/Size at Sexual Maturity: At 5 years and at 8 in $(20.3 \mathrm{~cm})$ total length (Bishop 1947:43). Retains external gills as an adult.

Breeding Period: Autumn (Bishop 1947:42). 

Egg Deposition: May and June of the year following mating. Reproduces in flowing water (01iver 1955:211). Prefers water depths of at least $3 \mathrm{ft}(0.9 \mathrm{~m})$ and bottoms with weeds and rocks to provide nesting cover. Nest sites often under large rock slabs in water depths of 6 to 8 in $(15$ to $20 \mathrm{~cm}$ ) in New York (Stewart $1961: 68$ ).

No. Eggs/Mass: 18 to 180 eggs (average 60 to 100) in water beneath objects, attached singly by stalks (Bishop 1941:26).

Time to Hatching: 38 to 63 days, female guards eggs (Bishop 1941:27).

Home Range/Movement: Unreported.

Food Habits/Preferences: In New York, aquatic insects comprised 30\% of the diet by weight, particularly nymphs and larval forms, crustaceans 33\%, small fish $13 \%$, also mollusks, spawn, other amphibians, worms, leeches and plants (Hamilton 1932). Most food captured at night along the bottom.

Comments: The mudpuppy is chiefly nocturnal, bottom dwelling, and active through the winter, when it moves to deeper water.

Selected References: Bishop 1947, Logier 1952. 



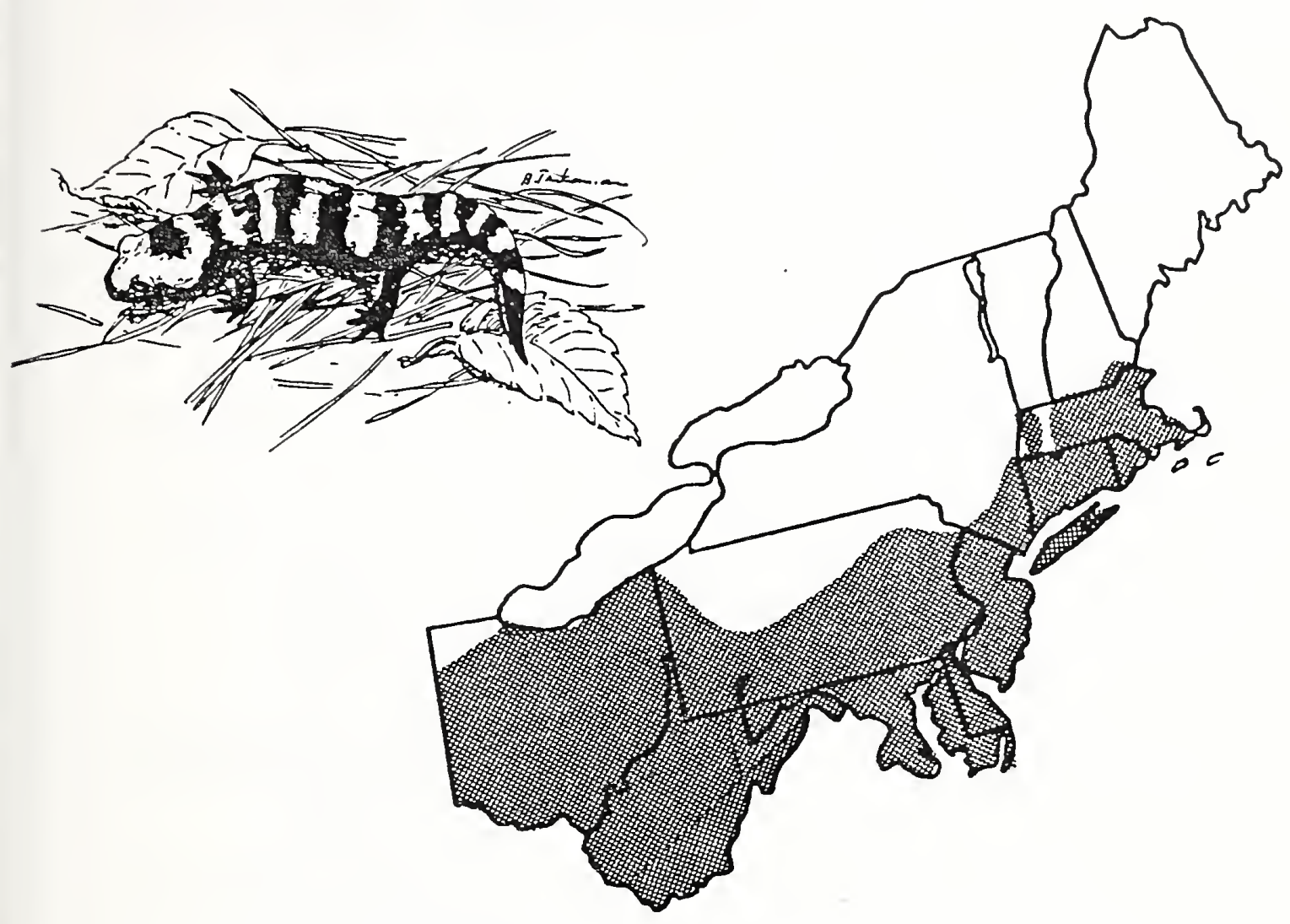

Range: New Hampshire and c. Massachusetts, c. Pennsylvania to s. Illinois, s. Missouri to e. Texas. Throughout the e. U.S. except s. Louisiana and Florida.

Relative Abundance in the Northeast: Uncommon.

Habitat in the Northeast: Sandy and gravelly areas of mixed deciduous woodlands, especially oak-maple and oak-hickory (Minton 1972:46), trap rock slopes ( $M$. Klemens, pers. commun.). During breeding season found in low areas around ponds, swamps and quiet streams. Inhabits somewhat dryer areas than other species of Ambystoma. During the summer usually found under logs and rocks. Larvae usually found in temporary water throughout the winter. Probably hibernates in deep burrows.

Special Habitat Requirements: Ponds or swamps in wooded areas for breeding. Age/Size at Sexualy Maturity: 15 to 18 months.

Breeding Period: During the fall, adults migrate to breeding areas (September in northern parts of range). 
Egg Deposition: September to early October in northern parts of range (Bishop 1941:138).

No. Eggs/Mass: 50 to 232 (average 100) eggs laid singly in shallow depressions beneath surface materials (Bishop 1941:142). Eggs laid in dry beds of temporary ponds and streams or on land, or at the edge of ponds or swamps, where they will be washed into the water to hatch.

Time to Hatching: 15 to 207 days; female forms a nest site and may brood eggs (01iver 1955:234).

Eggs Hatch: Usually in fall or early winter when submerged but without rain will hatch in spring.

Larval Period: Larvae overwinter with little growth until spring, and transform to terrestrial form in late May to June (Noble and Brady 1933). A higher temperature and abundant food supply will hasten metamorphosis (Stewart 1956b). The larval period was 135 days in New Jersey (Hassinger et a1. 1970).

Home Range/Movement: Adults migrate an average of $194 \mathrm{~m}$ from breeding sites to summer range in Indiana (Williams 1973 cited in Semlitsch $1980 \mathrm{~b}: 320)$.

Food Habits/Preferences: Arthropods, including adults and larval insects and crustaceans. Also takes earthworms and mollusks. Marbled salamander larvae eat small aquatic insects, crustaceans and other small invertebrates and are cannibalistic (Minton 1972:47). Larvae rise in the water column to feed ( $T$. Tyning, pers. commun.).

Corments: Terrestrial and nocturnal, often using runways of other animals or tunnels through loose soil. Young larvae are aquatic and primarily nocturnal.

Selected References: Bishop 1941, Anderson 1967b, Hassinger et al. 1970, Laze11 1979. 


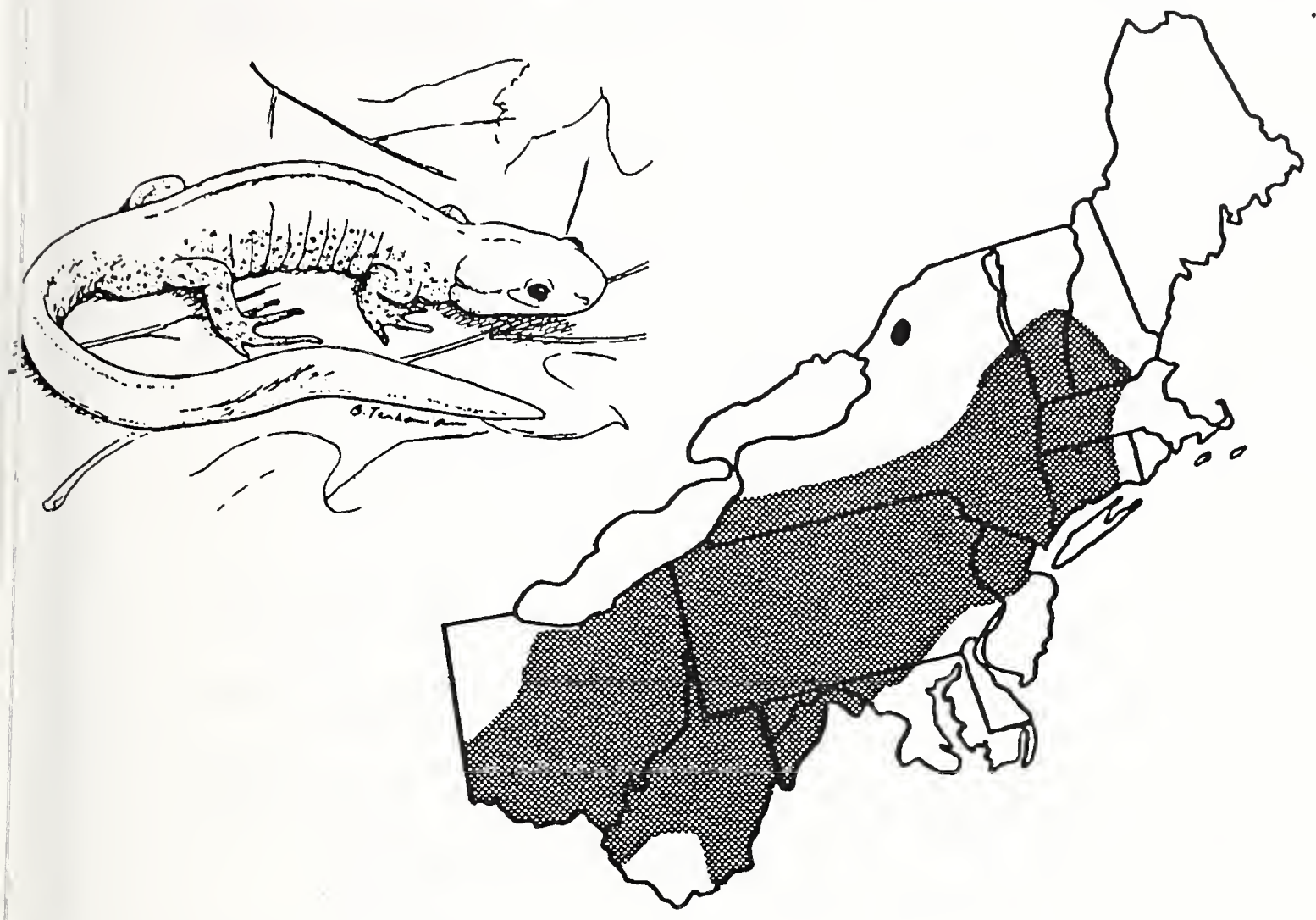

Range: Western New England to w.c. Indiana, c. Kentucky to w. Virginia and north to $n$. New Jersey.

Relative Abundance in the Northeast: Locally common to rare.

Habitat in the Northeast: Terrestrial, found in undisturbed damp, shady deciduous or mixed woods, bottomlands, swamps, ravines, moist pastures, or lakeshores. Hides beneath leaf litter, under stones or in decomposing logs and stumps. Cleared strips create a barrier for dispersal (Pough and Wilson 1976). In Connecticut, members of the Ambystoma jeffersonianum complex are more abundant and widespread in upland areas of the Connecticut River Valley (M. Klemens, pers. commun.). Hibernates on land in winter months, usually near breeding waters.

Special Habitat Requirements: Requires temporary ponds for breeding period. Age/Size at Sexual Maturity: Females at 21 months (Bishop 1941:102), snout to vent length 70 to $75 \mathrm{~mm}$ males, 75 to $80 \mathrm{~mm}$ females (Minton 1954). Juveniles probably enter the breeding population at 2 to 3 years of age (Wilson 1976 cited in Thompson et a1. 1980:119). 

Breeding Period: February to April, migrates to ponds for spawning (Brandon 1961).

Egg Deposition: February to April, of ten beneath ice. Will tolerate $\mathrm{pH}$ of 4 to 8 , with best hatching success at 5 to $6 \mathrm{pH}$ range (Pough and Wilson 1976). Isolated upland pools bordered by shrubs and surrounded by forest were primary breeding sites in Maryland (Thompson et al. 1980).

No. Eggs/Mass: 107 to 286 eggs (01iver 1955:234). Many variations of egg deposition, laid singly or in small cylindrical masses of 1 to 35 eggs each, in water attached to twigs or plants, under rocks, or in the bottom detritus of a pond (Stille 1954), in small pools of bogs (Bleakney 1957). Egg masses average 16 eggs per mass (Bishop 1941:94).

Time to Hatching: 30 to 45 days (Bishop 1947:135). 13 to 45 days (01iver 1955:234).

Larval Period: 56 to 125 days (Bishop 1941:99). Found overwintering in Nova Scotia (Bleakney 1952).

Home Range/Movement: Adults migrated an average of $252 \mathrm{~m}$ from breeding ponds to summer range in Indiana. Newly metamorphosized

individuals moved an average $92 \mathrm{~m}$ from the ponds (Williams 1973 cited in Semlitsch 1980b:320).

Food Habits/Preferences: Small invertebrates, including worms, millipedes, spiders, insects, and aquatic crustaceans. Feeds on most animal life that it can capture.

Selected References: Logier 1952, Uzze11 1967a, Pough and Wilson 1976. 



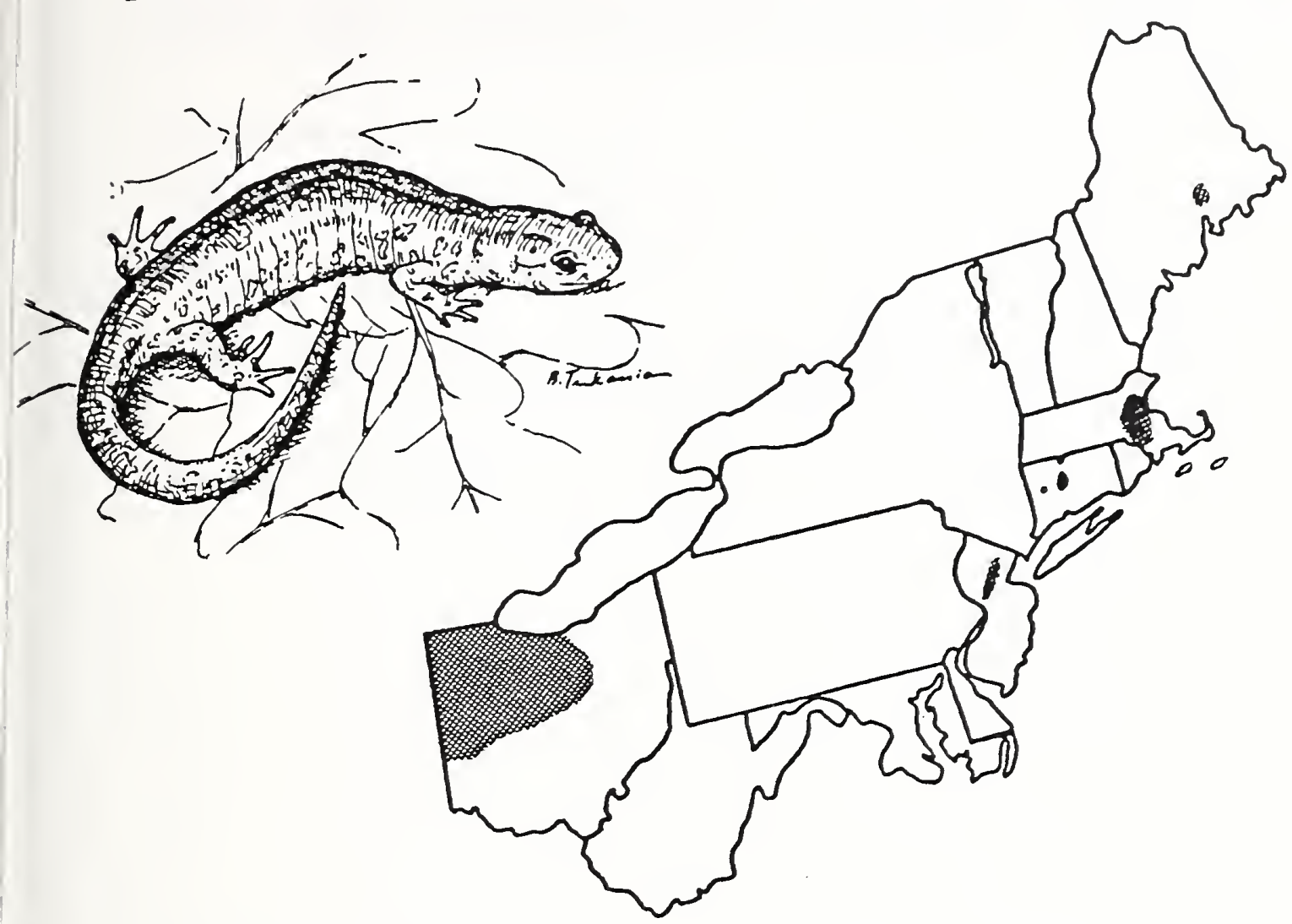

Range: Disjunct colonies in New Brunswick, Ottawa River drainage, e. Massachusetts, n.w. Ohio, Indiana and Michigan, and n. Wisconsin. (Connecticut record dependent on interpretation of electrophoretic data.).

Relative Abundance in the Northeast: Rare.

Habitat in the Northeast: Deciduous forests surrounding small ponds or lakes (Minton 1972:37). Have been found under logs.

Special Habitat Requirements: Woodland ponds for breeding.

Age/Size at Sexual Maturity: Unreported.

Breeding Period: March in Indiana (Minton 1972:38).

Egg Deposition: April (Uzzell 1964).

No. Eggs/Mass: 135 to 162 eggs (Uzze11 1964), laid in groups of 2, 3, or 4 , sometimes singly, in small clusters at pond bottoms or attached to submerged sticks (Uzze11 1967a:50.1). 

Larval Period: Transform in 95 to 101 days (Uzze11 1964). Larval period shortens as eggs are deposited later in the spring.

Time to Hatching: Unreported.

Home Range/Movement: Unreported.

Food Habits/Preferences: Thought to be similar to A. Zaterale.

Comments: Triploid of hybrid origin (similar to A. Zaterale). Female population only, depends on males of A. Laterale to stimulate egg development (Uzze11 1964).

Selected References: Uzze11 1964, 1967a; Minton 1972. 



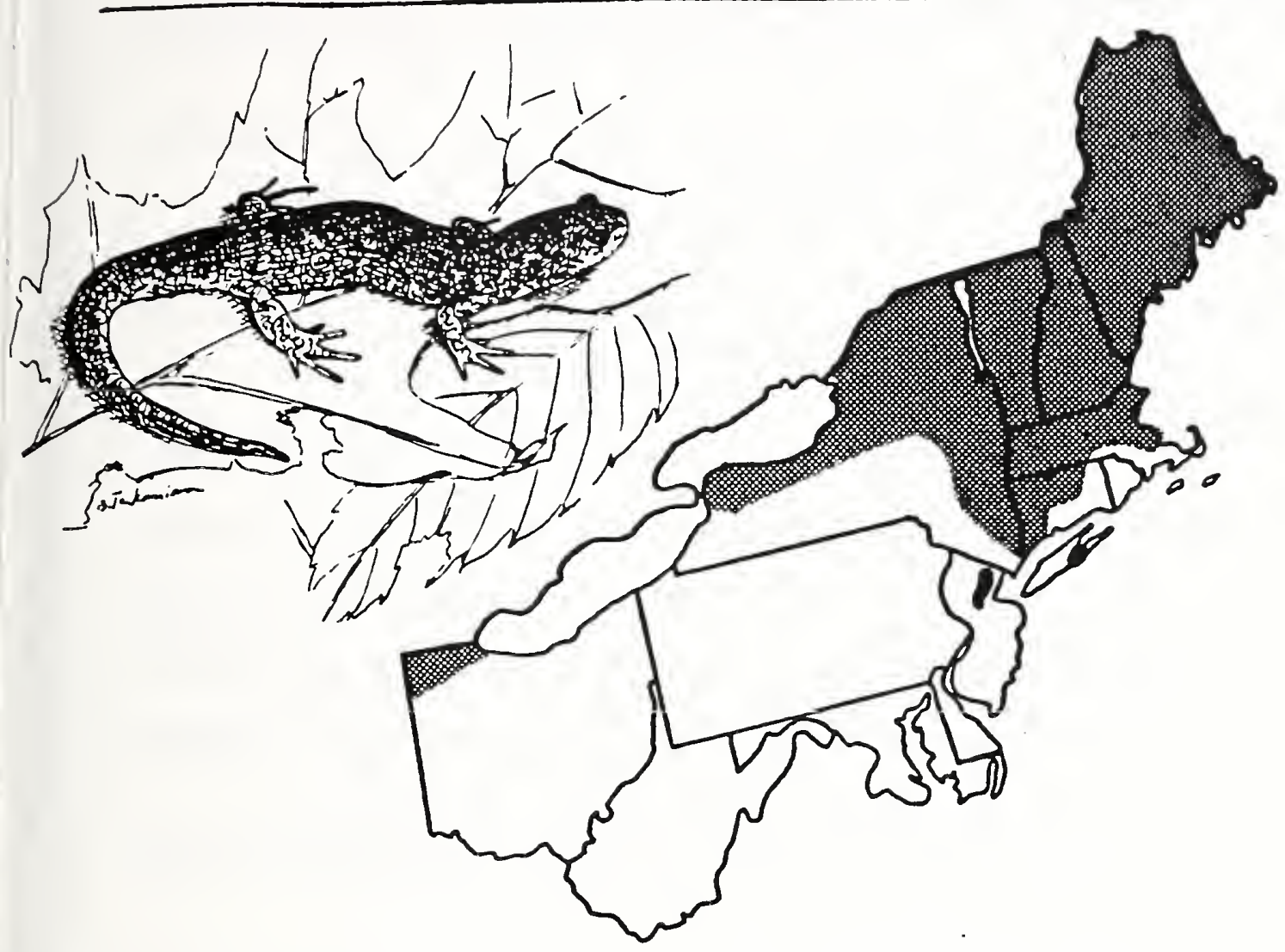

Range: Southeastern Quebec and the $n$. shore of the Gulf of St. Lawrence to James Bay and the $s$. end of Lake Winnipeg, south to $n$. Illinois and Indiana, n. New York and New England. Disjunct colonies in New Jersey, Long Island, Iowa and Labrador.

Relative Abundance in the Northeast: Rare; threatened in southern portion of range.

Habitat in the Northeast: Wooded, swampy or moist areas (Minton 1954). Occasionally in overgrown pastures. Sometimes occurs where soil is sandy, and may be found under logs or other forest debris. Occurs in a wide range of elevations (in w. Connecticut) and along the Connecticut River floodplain (M. Klemens, pers. commun.).

Special Habitat Requirements: Ponds or semi-permanent water for breeding. Age/Size at Sexual Maturity: Snout to vent length of 47 to $55 \mathrm{~mm}$ in Indiana (Minton 1954). 

Breeding Period: During early spring rains when night temperatures are above freezing (Lazell 1968).

Egg Deposition: March to early April. Eggs are laid on the bottoms of temporary shallow forest ponds, roadside drainage ditches, kettle holes (Landre 1980), attached to litter (Stille 1954), and twigs (Uzze11 1967b:48.1).

No. Eggs/Mass: 199 to 247 eggs (Uzzell 1964), 82 to 489 (Minton 1972:36). Laid in clusters of less than 30 eggs per cluster (Bleakney 1957), 6 to 10 eggs per mass (Landre 1980).

Time to Hatching: About 1 month (Smith 1961:28).

Larval Period: Extending to late June or mid-August (Smith 1961:28).

Home Range/Movement: Unreported.

Food Habits/Preferences: Arthropods, annelids and centipedes.

Comments: Acid precipitation and habitat loss are major threats to this species in the Northeast.

Selected References: Bleakney 1957; Uzzell 1964, 1967b; Landre 1980. 


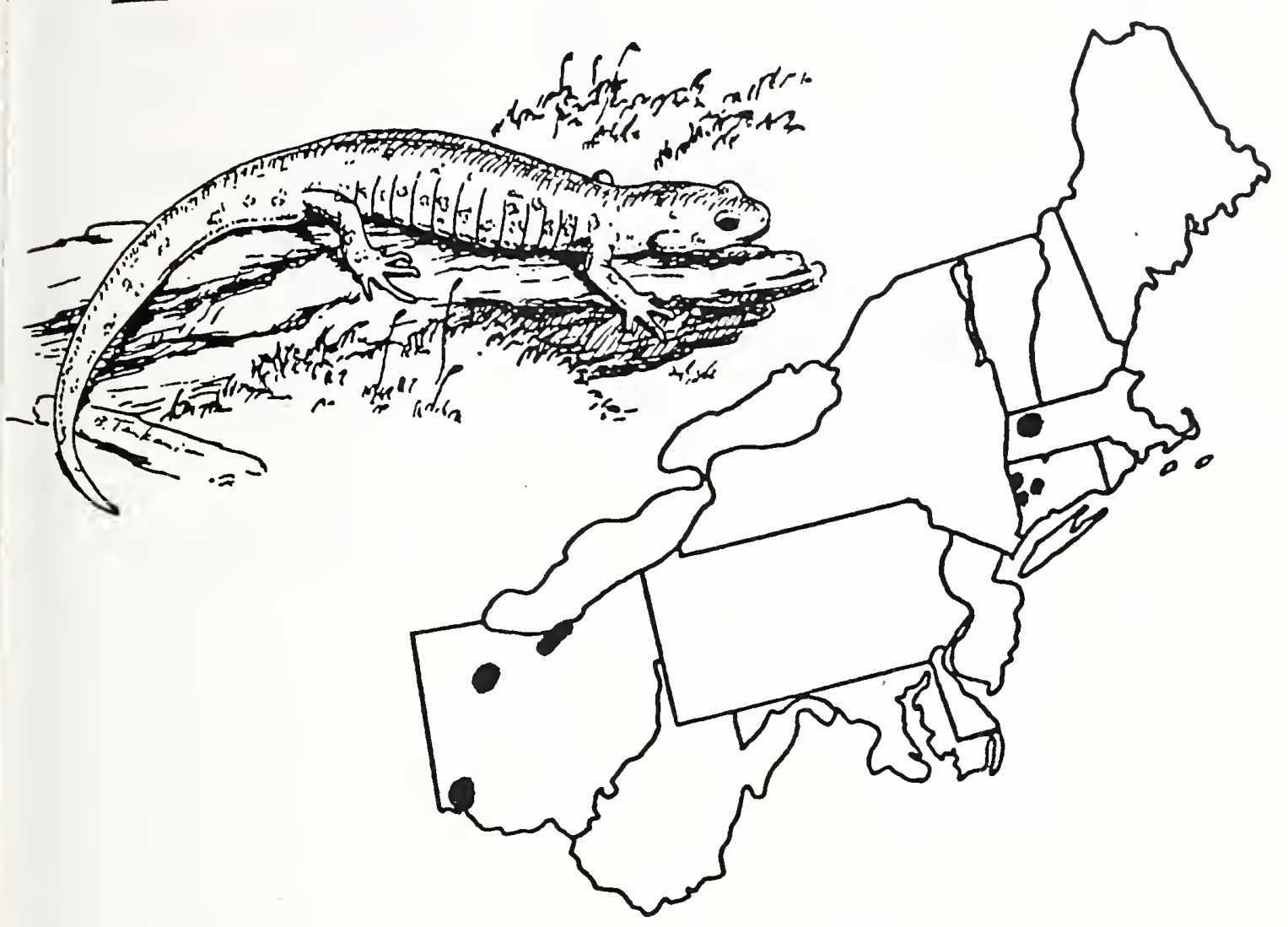

Range: Occurs with $A$. jeffersonionum; however, range is mainly restricted to areas north of the Wiscons in Glacial border where ranges of A. jeffersonianum and $A$. Zaterale meet or overlap. Central Indiana east to $n$. New Jersey and w. Massachusetts.

Relative Abundance in the Northeast: Locally common.

Habitat in the Northeast: Probably similar to that of A. jeffersonianum.

Special Habitat Requirements: See A. jeffersonionum.

Age/Size at Sexual Maturity: Unreported.

Breeding Period: March to April (Behler and King 1979:296).

Egg Deposition: Unreported.

No. Eggs/Mass: Typically 15 to 20 eggs/mass, in cylindrical masses attached to submerged twigs and grass stems. Rarely if ever attached to pond bottom debris (Uzze11 1967c:49.1). 
Home Range/Movement: Unreported.

Food Habits/Preferences: Unreported.

Comments: A hybrid of Jefferson and blue-spotted salamanders with 3 sets of chromosomes ( 2 sets from Jefferson and 1 from blue-spotted). Most are female, only one male has been recorded (Smith 1978:88). Genetic material is not contributed by male Jefferson; the sperm only stimulates egg production (Uzzell 1964). A. jeffersonianzom and $A$. Laterale probably developed from a common ancestor that was reproductively isolated by the Wisconsin Glaciation. As the glacier retreated and the two species mixed, hybridization occurred (Uzzell 1964).

Selected References: Uzzell 1964, 1967c; Smith 1978. 



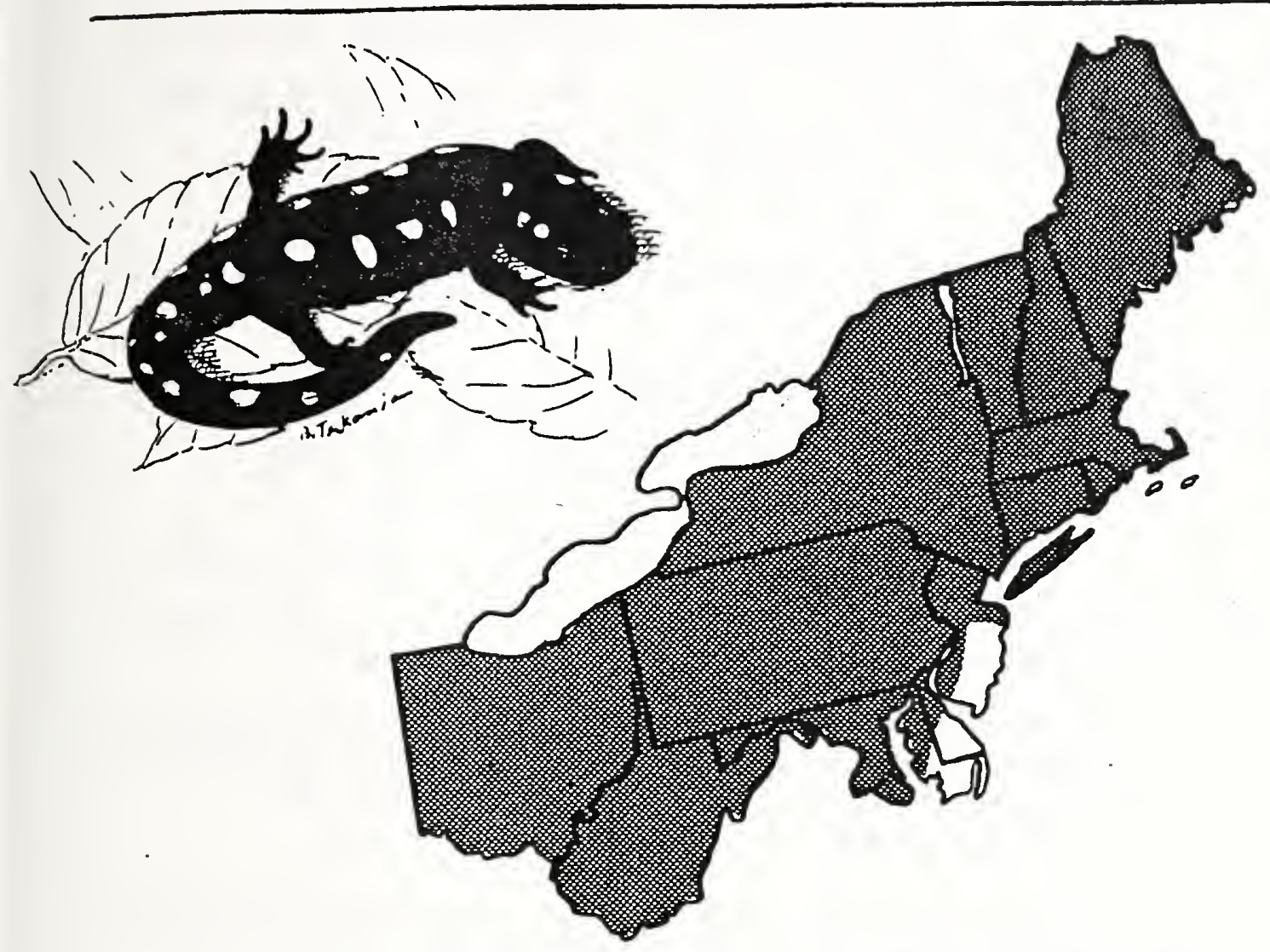

Range: Nova Scotia and the Gaspé Peninsula to $\mathrm{s}$. Ontario, south through Wisconsin, s: Illinois excluding prairie regions, to e. Kansas and Texas, and through the e. U.S., except Florida, the Delmarva Peninsula and s. New Jersey.

Relative Abundance in the Northeast: Common, al though populations declining, probably due to acid precipitation.

Habitat in the Northeast: Fossorial; found in moist woods, streambanks, beneath stones, logs, boards. Prefers deciduous or mixed woods on rocky hillsides and shallow woodland ponds or marshy pools that hold water through the summer for breeding. Usually does not inhabit ponds containing fish. Terrestrial hibernator. In summer often wanders far from water source. Found in low oakhickory forests with creeks and nearby swamps in Illinois (Cagle 1942 cited in Smith 1961:30).

Special Habitat Requirements: Mesic woods with semi-permanent water for breeding. Eggs tolerate a pH range of 6 to 10 with best hatching success at $\mathrm{pH}$ of 7 to 9 (Pough and Wilson 1976). High embryonic mortality occurred in temporary pools with $\mathrm{pH}$ below 6.0 in New York (Pough 1976). 

Age/Size at Sexual Maturity: During second year.

Breeding Period: March to mid-Apri1. Large numbers congregate at night at breeding ponds and may use the same track each year (Shoop 1965). Breeding migrations occur during steady evening rainstorms.

Egg Deposition: 1 to 6 days after first appearance of adults at ponds (Bishop 1941:114).

No. Eggs/Mass: 100 to 200 eggs, average of 125, laid in large masses of jelly, sometimes milky, attached to stems about $15 \mathrm{~cm}$ ( 6 in) under water. Each female lays 1 to 10 masses (average of 2 to 3) of eggs (Wright and Allen 1909).

Time to Hatching: 31 to 54 days (Bishop 1947:145).

Larval Period: 61 to 110 days, found overwintering in Nova Scotia (BTeakney 1952). Transforms July to September.

Home Range/Movement: Individuals have been found up to $1 / 4 \mathrm{mi}(400 \mathrm{~m})$ from the nearest breeding site in North Carolina (Gordon 1968). Will travel 91.2 to $182.4 \mathrm{~m}$ ( 100 to $200 \mathrm{yd}$ ) from woods to ponds in open meadows in New York (M. Stewart, pers. commun.).

Food Habits/Preferences: Earthworms, snails, slugs, insects, spiders, particularly larval and adult beetles (Wacasey 1961). Larval stage may also eat small fish. Cannibalism by larvae occurs under crowded conditions.

Comments: Nocturnal; travel only on ground surface for migrations to and from breeding pools. Rainfall, snowmelt, or high humidity coupled with air temperature of $10 \mathrm{C}\left(50^{\circ} \mathrm{F}\right)$ or more, are necessary for migrations to breeding pools. Numbers declining, primarily due to over-collection and acid rain.

Selected References: Shoop 1965, Anderson 1967a. 



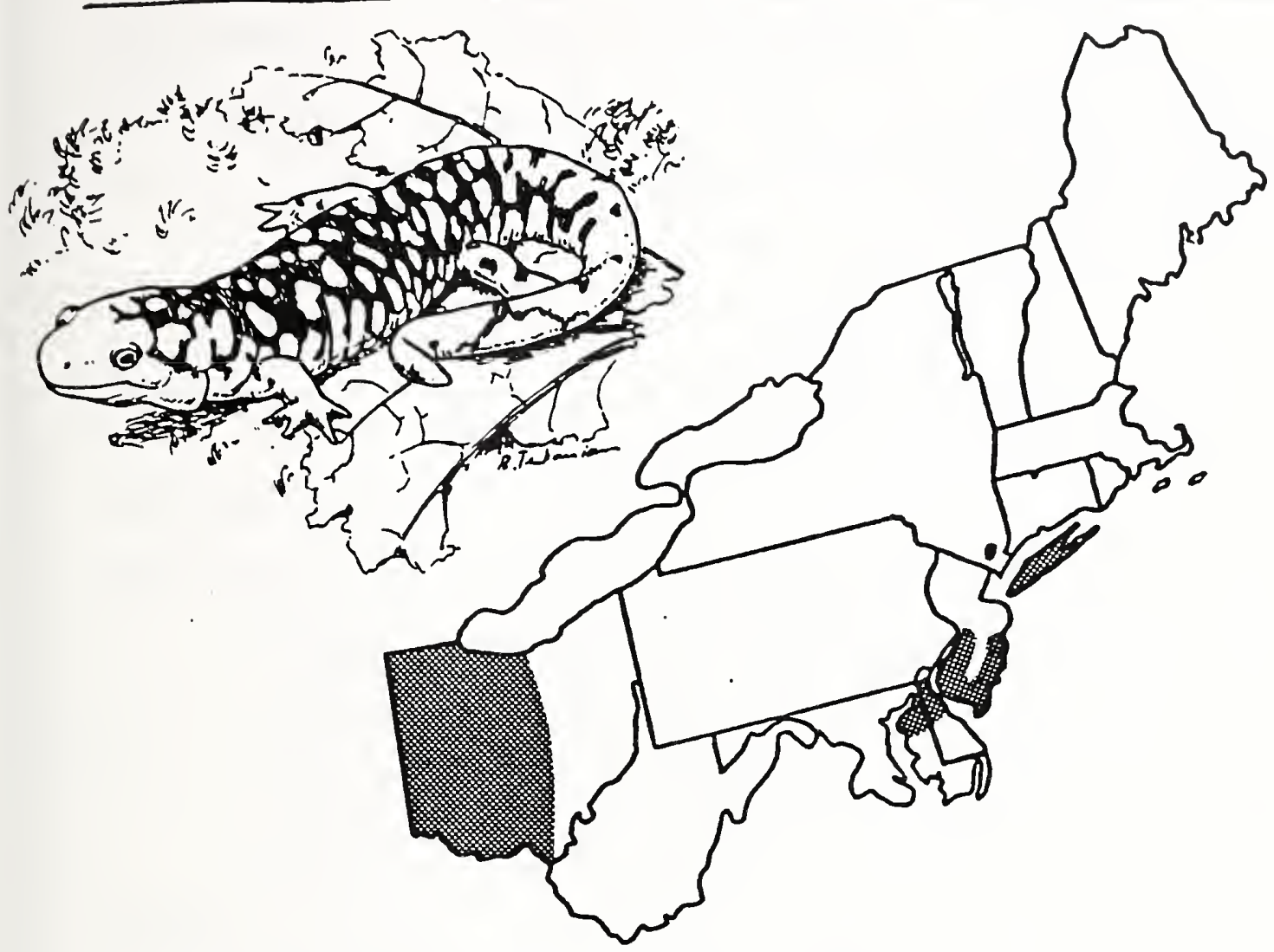

Range: Long Island along the Atlantic Coast to n. Florida. Central Ohio to s.e. Manitoba and south through e. Texas to the Gulf of Mexico. Absent from the Appalachian uplands and the lower Mississippi delta area.

Relative Abundance in the Northeast: Rare.

Habitat in the Northeast: Terrestrial, burrowing species found in moist woods, pine woods, alpine forests or open grasslands, marshes, swamps, cultivated areas, disturbed areas. Populations found in gravel pit ponds in New Jersey. Digs burrows or uses those of other animals, but is also found under rocks and logs. Hibernates at the bottom of ponds or underground.

Special Habitat Requirements: Mesic woods, ponds for breeding.

Age/Size at Sexual Maturity: Spring after transformation (Bishop 1941:169).

Breeding Period: Early spring; March in north. This species regularly breeds during the "January thaw" in New Jersey with eggs remaining under the ice a month after deposition (Hassinger et al. 1970). Breeds in the deep water of woodland or farm ponds, deeper water than that used by the spotted salamander (A. maculatum). 

Egg Deposition: Late February to late March.

No. Eggs/Mass: Approximately 1000 eggs (Smith 1956:42), average 44 to 59 eggs/mass (Hassinger et al. 1970), 23 to 110 eggs/mass (Bishop 1941:162), laid singly or in gelatinous clumps free or attached to submerged weeds or twigs (Gehibach 1967:52.1).

Time to Hatching: 14 to 30 days or longer, 30 to 40 days in the Northeast (Hassinger et al. 1970).

Larval Period: 75 to 140 days (Bishop 1941:167). Metamorphosis triggered by drying of ponds (Hassinger et al. 1970).

Home Range/Movement: Unreported.

Food Habits/Preferences: Isopods, terrestrial insècts, centipedes, earthworms, spiders, and other small invertebrates including mollusks. Also take small fish, frogs, tadpoles, smaller salamanders of their own or other species and occasionally young mice. Most common food items are those found in moist, dark microhabitats (Lindquist and Bachman 1970). Larvae are nocturnal feeders. A. tigrinum will hide in their burrows with their heads at the surface to sieze nearby prey items (Gruberg and Stirling 1972).

Comments: Nocturnal. Disappearing rapidly due to habitat destruction; may no longer occur in New York State outside Long Island

(M. Stewart, pers. commun.).

Selected References: Bishop 1941, Smith 1961, Gehlbach 1967. 



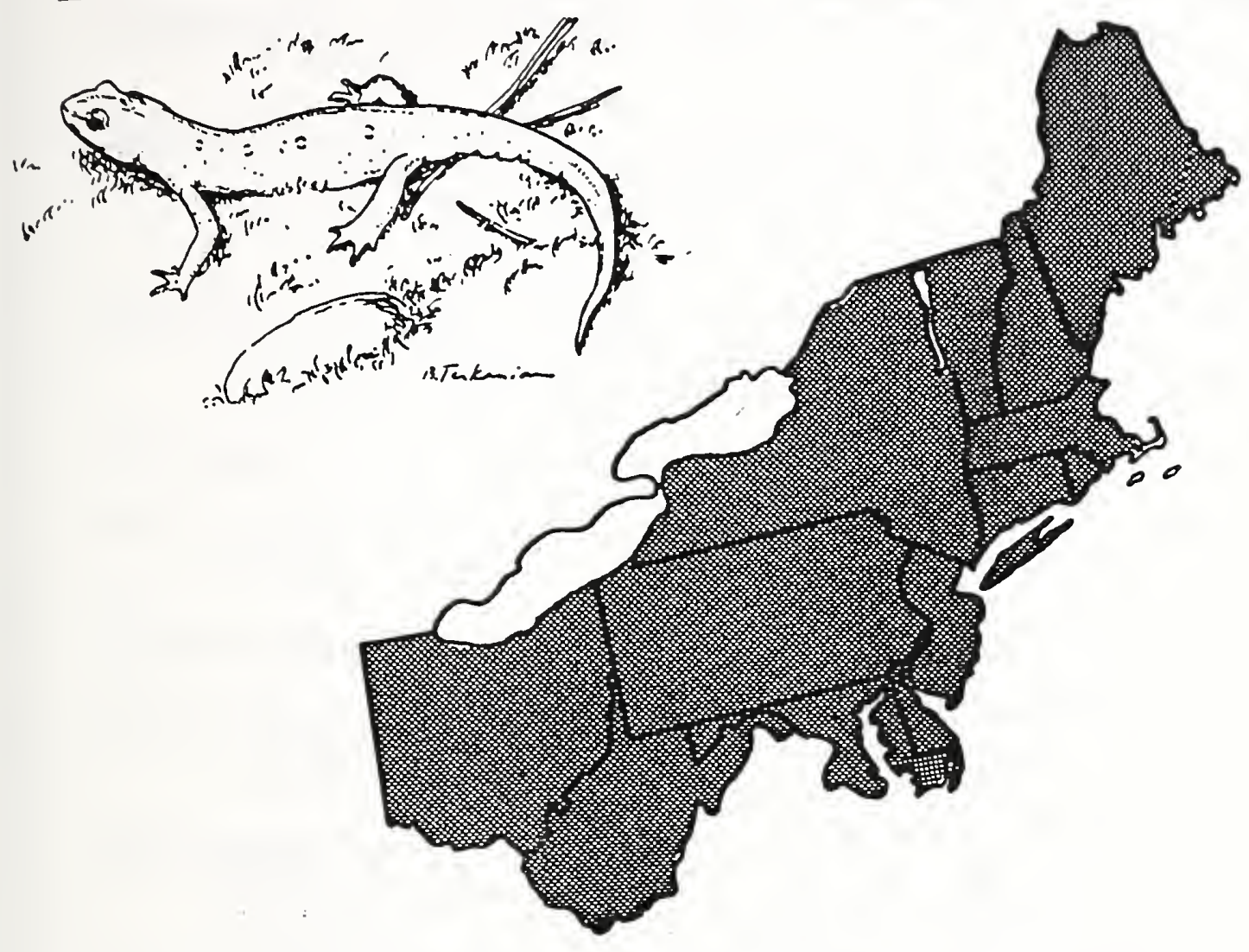

Range: Nova Scotia and the Gaspe Peninsula west to the $n$. shore of Lake Superior and e. Michigan south to c. Alabama, n.c. Georgia. Absent along coast from s.e. South Carolina, southward.

Relative Abundance in the Northeast: Common.

Habitat in the Northeast: Adults found in ponds, particularly water with abundant submerged vegetation, and in weedy areas of lakes, marshes, ditches, backwaters, and pools of shallow slow-moving streams or other unpolluted shallow or semi-permanent water. Juveniles live in moist areas on land, typically under damp leaves, under brush piles or logs and stumps, usually in wooded habitats. More common in areas of higher elevation in Connecticut (M. Klemens, pers. commun.); from sea level to $1.6 \mathrm{~km}$ elevation on Mt. Marcy in the Adirondacks (M. Stewart, pers. observ.). Moist beech-maplehemlock woods in New York (Hurlbert 1969), and oak-pine woods in Massachusetts (Healy 1974). May be seen moving about on wet days in spring and summer. Some may hibernate on land, burrowing under logs and debris, but most adults remain active all winter underwater in pond bottoms or in streams. During winter months often found semi-active in groups of 20 to 40 (Morgan and Grierson 1932). 

Red-spotted Newt

Special Habitat Requirements: Water with aquatic vegetation for the adult newt.

Age/Size at Sexual Maturity: 2 to 8 years (Healy 1974). Aquatic juveniles feed almost year-round and mature in 2 years. The eft feeds only during rainy summer periods and requires more time to reach maturity.

Breeding Period: Spring (April to June), fall (August to October), sometimes November to December (Hurlbert 1969). Characteristically breed in lakes, ponds, and swamps (Hurlbert 1970).

Egg Deposition: Late March to June.

No. Eggs/Mass: 200 to 375 eggs (Bishop 1941:64), laid in water, attached singly to the leaves of aquatic plants.

Time to Hatching: 3 to 5 weeks (Logier 1952:64), temperature dependent.

Larval Period: 12 to 16 weeks. Post-larval migration from aquatic to terrestrial habitat occurs from summer through late fall during diurnal rainfall in New York (Hurlbert 1970).

Home Range/Movement: Approximately $270 \mathrm{~m}^{2}$ for red efts (juveniles) in an oak-pine woodland in w. Massachusetts; maximum daily movement was $13 \mathrm{~m}$ (Healy 1974). Average movement along the edge of a smal1 pond in Pennsylvania was $10.1 \mathrm{ft}(3.1 \mathrm{~m})$ for females, and $11.2 \mathrm{ft}$ $(3.4 \mathrm{~m})$ for males; most individuals remained within $5 \mathrm{ft}(1.5 \mathrm{~m})$ of shore (Be11 is 1968).

Food Habits/Preferences: Both adults and larvae are opportunistic feeders (Burton 1977). Insects and their larvae, particularly mayfly, caddisfly, midge and mosquito larvae (Ries and Bellis 1966), springtails (MacNamara 1977); tadpoles, frog eggs, worms, leeches, sma 11 mollusks and crustaceans, spiders, mites, occasionally smal1 minnows (Hamilton 1932), salamander eggs also a major food item (T. Tyning, pers. commun.). Also ingests molted skin. Snails are an important food source for the red eft (Burton 1976). Cannabalism on their own larvae provides an important component of the diet in July and August (Burton 1977).

Comments: Mates in ponds and streams. The red eft, the juvenile terrestrial form of the red-spotted newt, remains on land for 2 to 7 years; most remain on land 4 to 5 years, then return to the water where they transform to aquatic adults (Healy 1974). Some individual populations omit the terrestrial eft stage. Skin secretions of red efts are highly toxic--about 10 times more toxic than those of adults (Brodie 1968).

Selected References: Bishop 1947, Mecham 1967. 



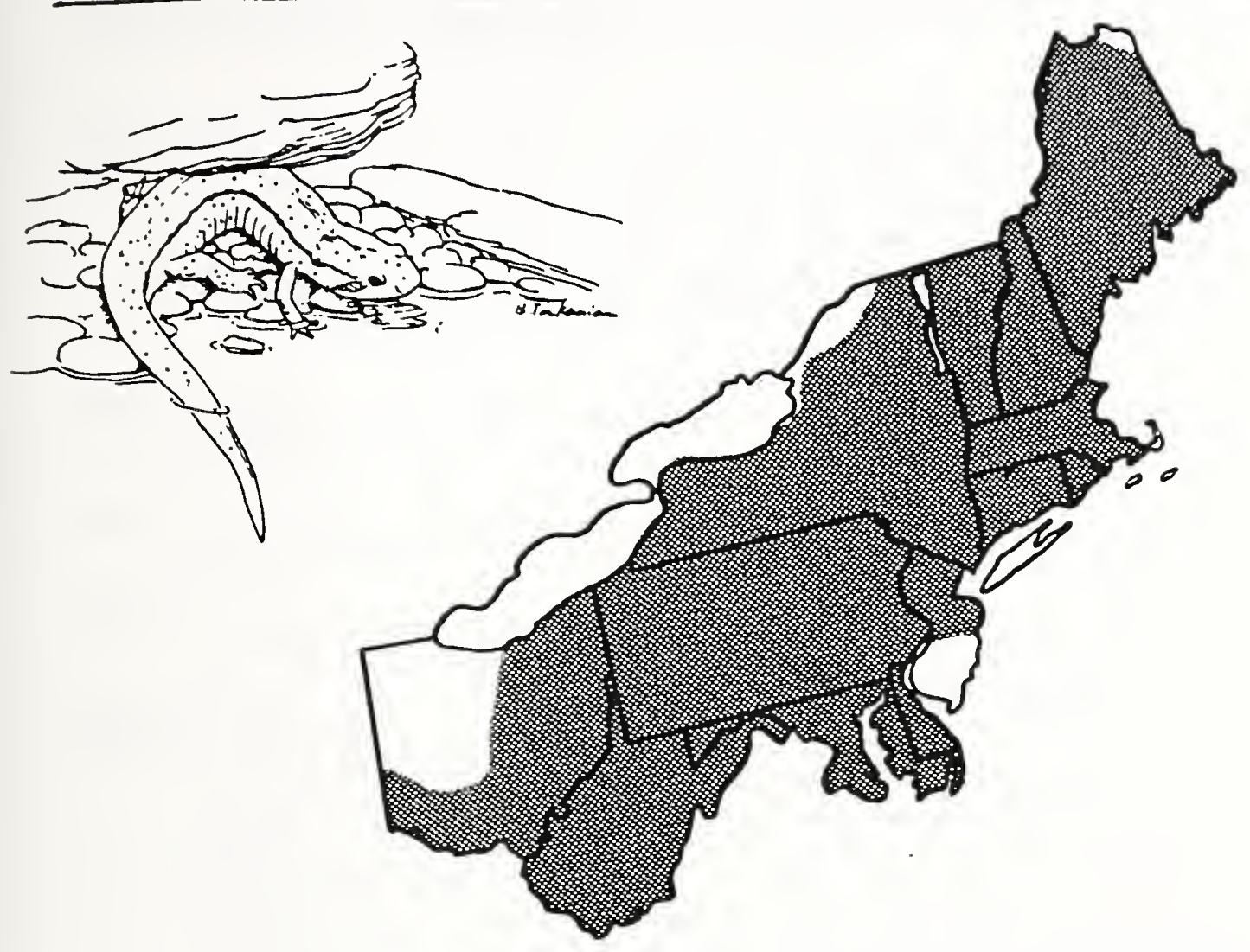

Range: Southern New Brunswick and s. Quebec to s.e. Indiana and c. Kentucky to the Carolinas; throughout the Northeast excluding $s$. New Jersey.

Relative Abundance in the Northeast: Common to abundant.

Habitat in the Northeast: In woodlands at the margins of cool running water, favors clear rocky streams; in springy banks, seepage areas, beds of semi-dry brooks; under the cover of wet leaves, moss, rock piles, other debris, or in burrows in the soil. Ventures from streamside only during wet weather. Occurs from sea level to mountain elevations. Moves under logs and rocks in deeper water to hibernate in September. May remain active throughout the winter in stream bottoms or deep in unfrozen soil (Ashton and Ashton 1978).

Special Habitat Requirements: Permanent streams or seeps in woodlands.

Age/Size at Sexual Maturity: About 3 years (Dunn 1926:92), males at 3.5 years, females deposit first eggs at 5 years (Organ 1961). Males mature at 2 years, females at 3 years (Danstedt 1975). Body size at maturity varies between populations (Tilley 1968). 

Breeding Period: Biannual cycle occurring late spring and fall (Organ 1961). Breeds in ponds or streams.

Egg Deposition: July to late August in w. Pennsylvania (Krysik 1980). Female guards the eggs in damp hollows beneath stones, under loose bark of logs, between wet leaf litter layers and in moss close to the water's edge. Larvae move to water where development continues (M. Stewart, pers. commun.). Clutches found less than $50 \mathrm{~cm}$ from the edge of streams and springs or in seepage areas (Krysik 1980).

No. Eggs/Mass: 8 to 28 stalked eggs in clusters, average 17 (Bishop 1947:314).

Time to Hatching: 52 to 57 days, Massachusetts (Wilder 1917), 5 to 8 weeks (Bishop 1941:318), about 10 weeks (Babbitt 1937:16).

Larval Period: 7 to 10 months, usually transform in June (Wilder 1913: 295). From 9 to 12 months in Maryland (Danstedt 1975).

Home Range/Movement: Less than $10 \mathrm{ft}(3 \mathrm{~m})$ along a stream in a wooded ravine in Pennsylvania (Barthalmus and Bellis 1969). Average range of $1.4 \mathrm{~m}^{2}$ in a gravel bottom stream in Ohio (Ashton and Ashton 1978). Average about $150 \mathrm{ft}^{2}\left(14 \mathrm{~m}^{2}\right)$ along a stream in Kentucky, maximum movement of $100 \mathrm{ft}(30.5 \mathrm{~m})$ as open water dried up (Barbour 1971:57). Average weekly movement less than $0.5 \mathrm{~m}$ (Ashton 1975). In an intermittent mounta in stream average for 5 individuals was $48 \mathrm{~m}^{2}$, daily movements less than $2 \mathrm{~m}$ (Barbour et a1. 1969b).

Food Habits/Preferences: Small aquatic and terrestrial invertebrates, insects--96\% of prey by weight (Burton 1976), grubs, worms, crustaceans, spiders, and occasionally mollusks; sometimes larvae of own species. Nocturnal feeder, also active on cloudy or rainy days.

Comments: Larval stage is aquatic, adults are riparian.

Selected References: Bishop 1947, Organ 1961, Ashton 1975. 



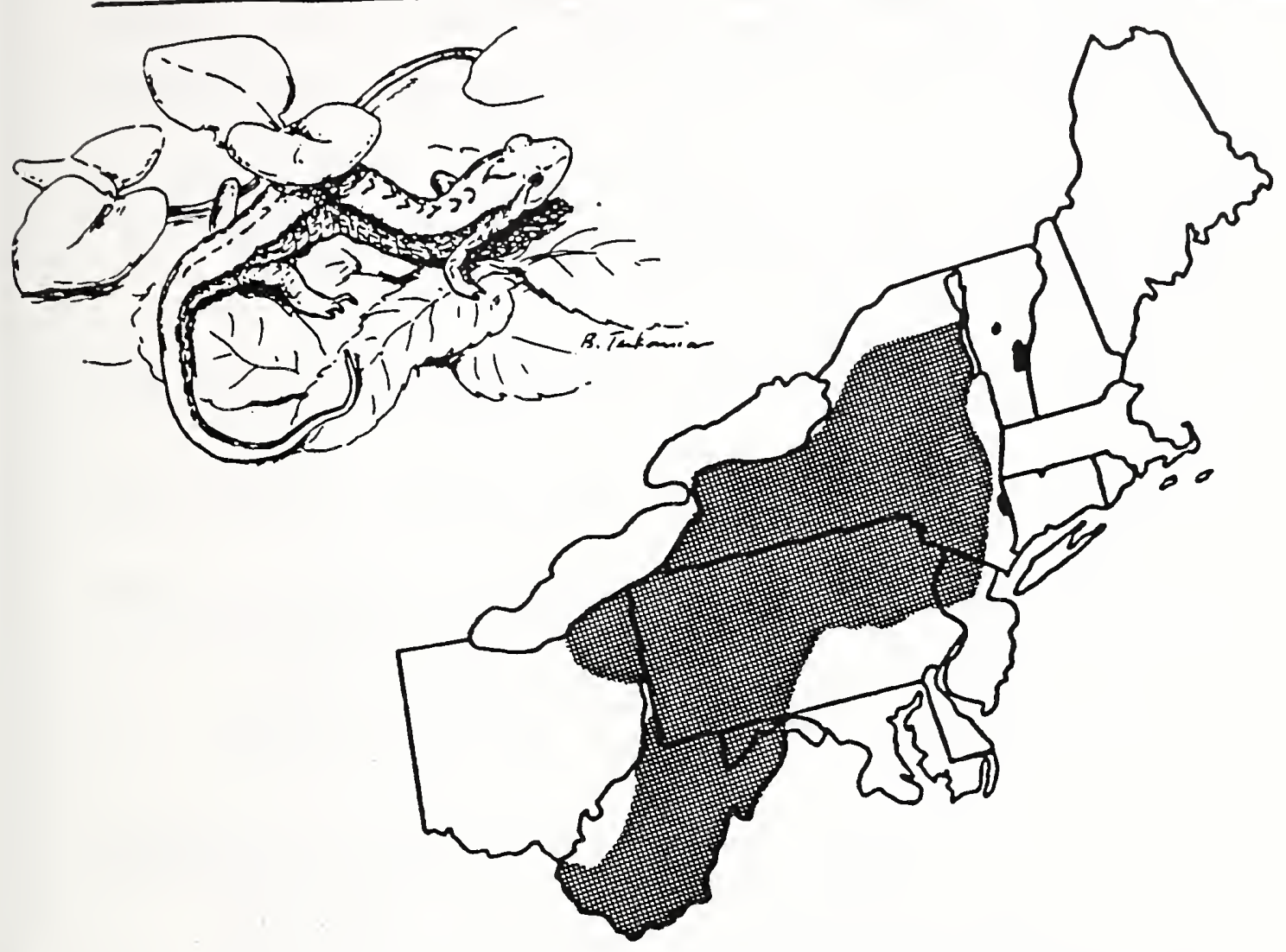

Range: Appalachian mountains and uplands from New York to $n$. Georgia at altitudes ranging from a few hundred feet (approx. $60 \mathrm{~m}$ ) above sea level to timberline in the s. Appalachians.

Relative Abundance in the Northeast: Common in appropriate habitats, but habitats are restricted.

Habitat in the Northeast: Semi-terrestrial, found along stream edges and on the forest floor. In wet woods under forest debris, logs, stones, sometimes beneath the bark of dead trees. Near water-small streams, springs or seeps. Seeps and springs used for late autumn and winter hibernation. Individuals inhabiting seepage banks are active earlier in spring and later in the fall than streamside individuals (Keen 1979).

Special Habitat Requirements: Seeps, springs or streams in woodland areas. Age/Size at Sexual Maturity: About 3 years: females at 36 months deposit clutch at 30 to $34 \mathrm{~mm}$ snout-vent length (Keen and Orr 1980). 

Breeding Period: Spring, autumn or winter (Fitzpatrick 1973).

Egg Deposition: Annual cycle occurring in late winter/spring or autumn, female guards eggs.

No. Eggs/Mass: 11 to 14 eggs (Bishop 1941:335). Stalked eggs deposited in clusters underneath stones or logs in small cavities. Fecundity in Desmognathus is size-dependent (Tilley 1968).

Time to Hatching: 50 to 70 days (Tilley 1972), hatching in fall and early spring.

Larval Period: 2 to 8 months (Tilley 1970); in the s. Appalachians, larvae occasionally overwinter (Tilley 1973:129.1).

Home Range/Movement: Average movement of 40 to $45 \mathrm{~cm}$ between captures of displaced and nondisplaced individuals in a rock-face habitat in North Carolina (Huheey and Brandon 1973). Homing to the nest shown by breeding females (Forester 1979). Females are philopatric, ovipositing in the same section of a stream in successive years (Forester 1977).

Food Habits/Preferences: Insects, including adult and larval forms of flies, beetles, wasps and ants. 01 igochaetes (Keen 1978), also takes other small arthropods (Huheey and Brandon 1973). Eats shed skin (Bishop 1941:341), suggesting that this species does not actively forage but eats only nearby prey (Keen 1979).

Comments: Basically nocturnal but also active on dark humid days. Will climb trees and shrubs to feed.

Selected References: Bishop 1947, Hairston 1949, Huheey and Brandon 1973, Tilley 1973. 



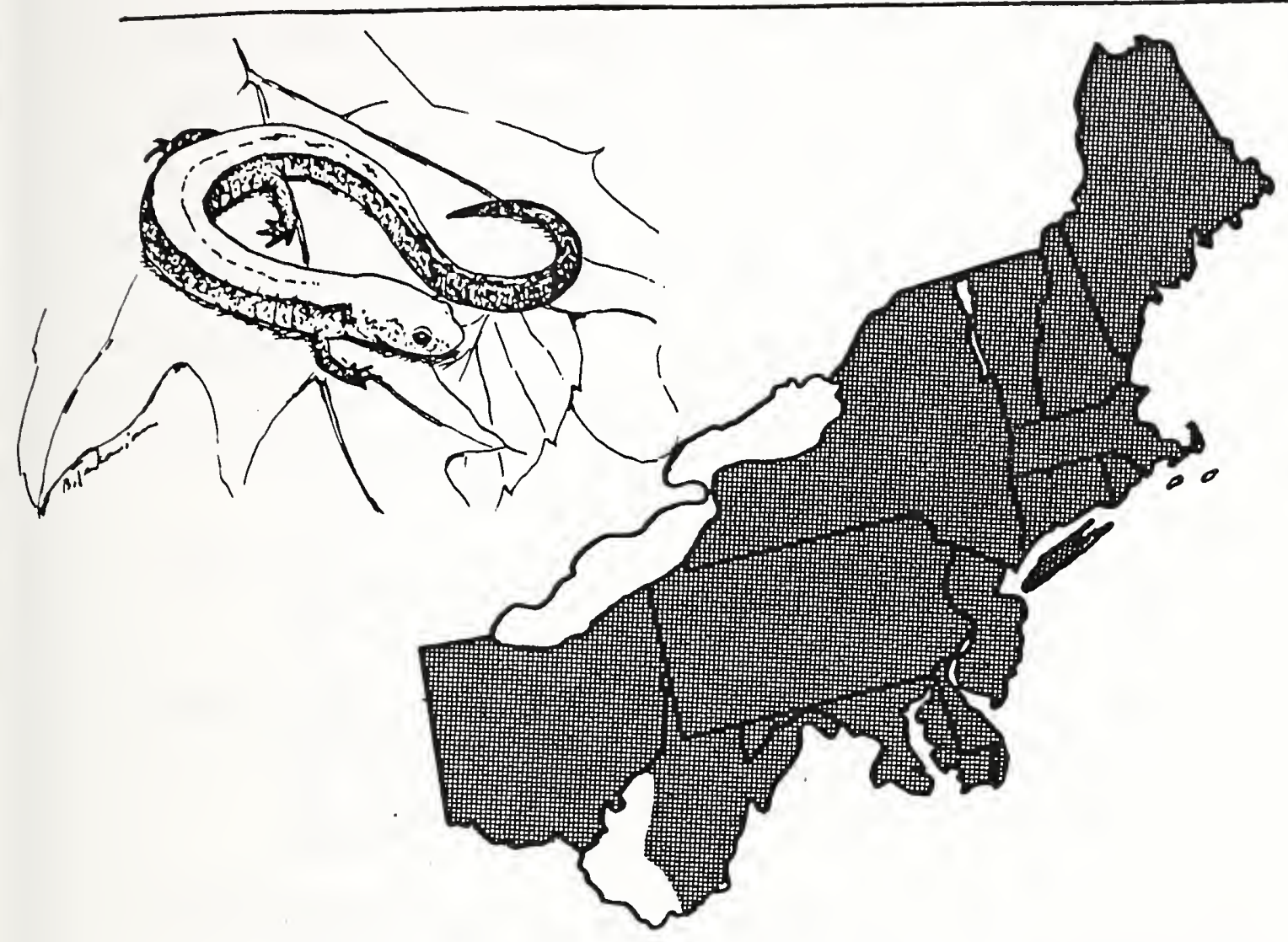

Range: Nova Scotia west to s. Ontario and e. Minnesota, south in scattered colonies to Missouri, in the Smoky Mountains, in 5 . Tennessee and east to Cape Hatteras.

Relative Abundance in the Northeast: Abundant.

Habitat in the Northeast: Entirely terrestrial. Mixed deciduous or coniferous woods, inhabiting interiors of decaying logs and stumps, also found underneath stones, moist leaf litter and bark. Wet areas and extremely moist bottomland avoided. Enters xeric, sandy habitats where moist micro-habitats exist ( $M$. Klemens, pers. commun.).

Hibernates down to 15 in $(38 \mathrm{~cm})$ soil depth (01iver 1955:121) or in rock crevices. May be active during mild winter weather (Minton 1972:67). In Indiana, individuals were found active in an ant mound throughout the winter (Caldwell 1975). Found hibernating 30 to 36 in $(76.2$ to $91.4 \mathrm{~cm})$ depth in decaying root systems of dead white oaks in s.e. Massachusetts (Hoff 1977). Has been found hibernating in aquatic situations in Maryland (Cooper 1956). 

Special Habitat Requirements: Logs, stumps, rocks, etc.

Age/Size at Sexual Maturity: Generally during second year (0liver 1955:277), but female ususally reproduces in third year (Burger 1935).

Breeding Period: Biannual cycle, spring and late fall (October through December) in Maryland (Sayler 1966).

Egg Deposition: June to July of next year.

No. Eggs/Mass: 3 to 14 eggs, average 7 to 10 , in small clusters attached to roof of small chamber, laid in and under rotted logs and stumps. Reproduce annualily in Connecticut (Lotter 1978).

Time to Hatching: 30 to 60 days (01iver 1955:234), extending 84 days in Maine (Banasiak 1974). Hatch in August to September. Larval stage is completed within egg.

Home Range/Movement: Home range is small due to restricted horizontal movements (Taub 1961). Movement of less than $1 \mathrm{ft}(30.5 \mathrm{~cm})$ for 14 individuals in hardwood forest habitat in New Jersey; individuals usually found under the same object where initially captured (Taub 1961).

Food Habits/Preferences: Small insects and their larvae, earthworms, snails, slugs, spiders, sowbugs, millipedes, mites (Surface 1913:95). Occasionally cannibalistic. Mites were the most important food, comprising $65 \%$ of the prey items in a New Hampshire study (Burton 1976), insects $73 \%$ by weight in a New York study (Jameson 1944). During rainy summer nights found on leaf litter presumably foraging for food (Burton and Likens 1975). Often climbs tree trunks and shrubs in search of food, particularly during wet nights.

Comments: Three distinct color phases occur, redback, leadback and erocrystic. In Connecticut, the redback morph occurs almost exclusively in cold upland areas; in areas of more moderate climate and elevation, both redback and leadback morphs occur (M. Klemens, pers. commun.). All records of erocrystic individuals occur north of $41^{\circ}$ and south of $47^{\circ}$ latitude (S. Tilley, pers. commun.). The redback salamander is the most abundant terrestrial vertebrate in New England and comprises the greatest amount of vertebrate biomass in Hubbard Brook Experimental Forest in New Hampshire (Burton and Likens 1975).

Selected References: Heatwole 1962, Smith 1963. 



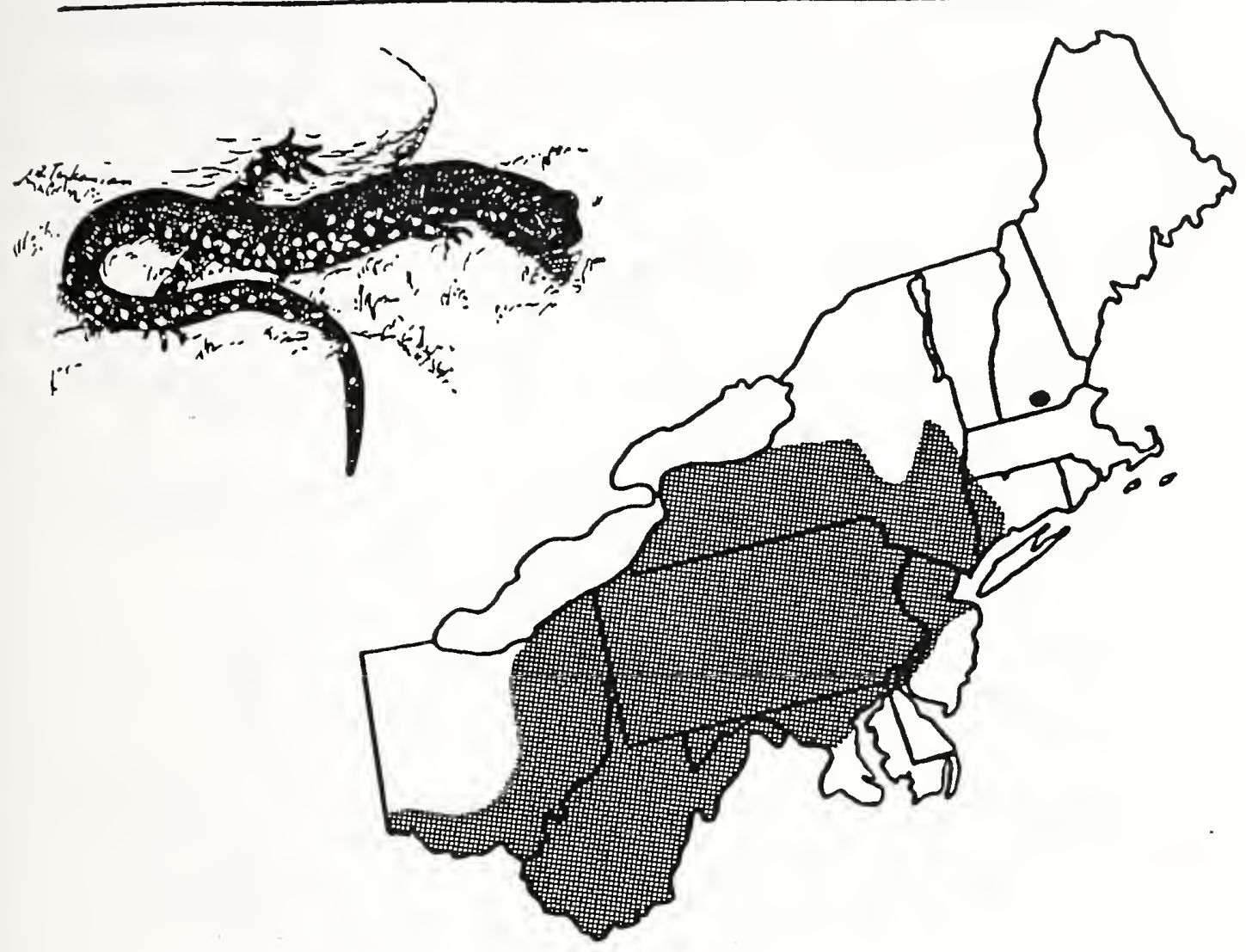

Range: Extreme w. Connecticut through c. New Nork to e. Oklahoma, Arkansas, south in Louisiana to c. Florida. Scattered colonies in S. New Hampshire and Texas.

Relative Abundance in the Northeast: Uncommon to rare.

Habitat in the Northeast: Moist wooded hillsides and ravines. Terrestrial, found underneath moist humus, in crevices in rock, and under logs in woodland areas. Has been found in second-growth oak-hickory forests and steep hemlock slopes of ravines in the Helderberg Mountains, New York (M. Stewart, pers. commun.). Also in mature mixed deciduous forests (Semlitsch 1980a). Hibernates underground from November to March or April.

Special Habitat Requirements: Rock outcroppings, logs within wooded areas. Age/Size at Sexual Maturity: Females mature at about 4 years and lay eggs in the fifth year, males at 4 years (Highton 1962). Lengths of 59 to $74 \mathrm{~mm}$ snout to vent length in females, 53 to $70 \mathrm{~mm}$ in males (Highton 1962). 

Breeding Period: Autumn and spring (Highton 1956).

Egg Deposition: Probable biennial oviposition occurring either in autumn or late spring in northern populations (Highton 1962). Eggs laid within rock crevices or rotted logs (Smith 1961:58).

No. Eggs/Mass: 13 to 34 eggs, average 16 to 17 (Highton 1962). Eggs aggregated in a thin envelopment. Fecundity increases with body size (Semlitsch 1980a).

Time to Hatching: Probably in late summer; entire larval period spent within egg.

Home Range/Movement: Twenty-two individuals in $n$. Florida were recaptured at or within $4 \mathrm{ft}(1.2 \mathrm{~m})$ of the original capture point (Highton 1956). Adult home ranges less than $9 \mathrm{~m}$ diameter, immatures less than $6 \mathrm{~m}$ diameter, in oak-hickory forest with thick leaf litter in North Carolina. Mean movement distances were $17.5 \mathrm{~m}$ for males, $14.3 \mathrm{~m}$ females, and $4.2 \mathrm{~m}$ juveniles. Probably capable of movements over $90 \mathrm{~m}$ beyond home range area (Wells and Wells 1976).

Food Habits/Preferences: Mostly insects, also sowbugs, worms, centipedes, spiders, slugs and snails (Hamilton 1932). Availability probably. governs feeding habits. Ants and beetles were the most abundant food items in a Virginia study, comprising $58 \%$ of the total weight of food (Davidson 1956).

Comments: Nocturnal, may be active during some rainy days. During hot, dry spells found deep underground or under logs in dense aggregations (Wells and Wells 1976).

Selected References: Bishop 1941, Highton 1956, 1962. 



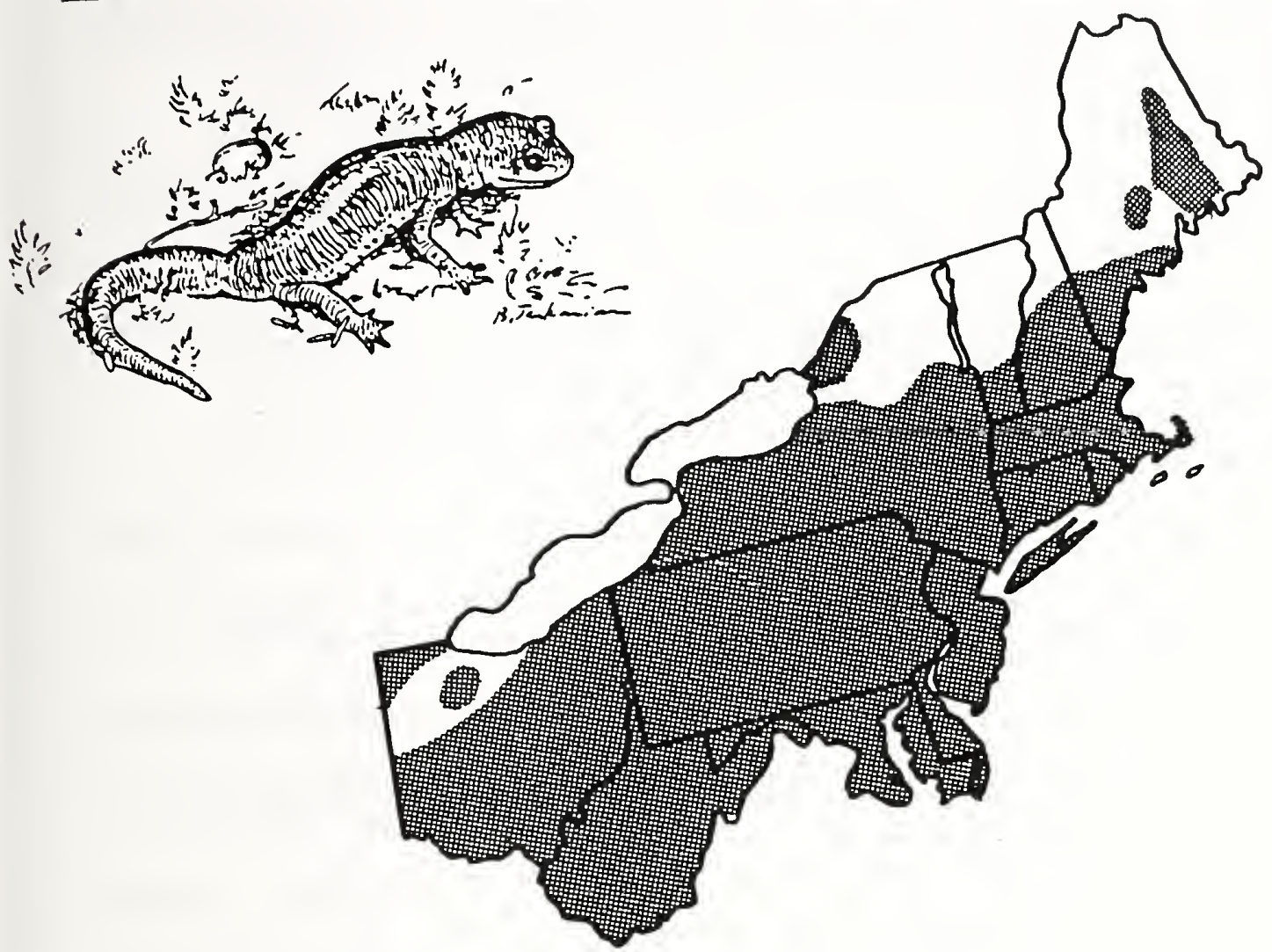

Range: Nova Scotia west to s. Ontario and Wisconsin, south to Alabama and Georgia. Absent from most of northern New England. Scattered disjunct populations occur in the e. U.S.

Relative Abundance in the Northeast: Uncommon to rare.

Habitat in the Northeast: Wet woodlands, preferably with sphagnum moss; shaded, shallow woodland pools; tamarack bogs. Hides in moss, in moist decaying wood, under stones or wet leaves. Prefers an acidic environment. Found in beech/maple, yellow birch/maple and other hardwood forests, found less often in coniferous woods (Neill 1962:2.1). Larval stage is aquatic, found in pools and quiet streams with an abundance of moss. Typically hibernates in decaying root systems of trees.

Special Habitat Requirements: Wet woodlands.

Age/Size at Sexual Maturity: About 2-1/2 years (Barbour 1971:74). 

Breeding Period: Late summer and autumn, peak in fall. Breeding area adjacent to mixed hardwood or northern conifer woods in West Virginia (N. Green, pers. observ.) and Albany County, New York (M. Stewart, pers. commun.).

Egg Deposition: March to Apri1 or May (B1anchard 1934, Barbour 1971:73). Nests located next to and just above water.

No. Eggs/Mass: 19 to 50 eggs (Dunn 1926:200, 202), average 50 in New York (Bishop 1941:183). Communal nesting may occur with up to 800 eggs laid per nest. One to four females will remain with eggs (Wood 1953). Eggs laid singly; adhered to moss, roots, decayed leaves.

Time to Hatching: 38 to 60 days (Blanchard 1934).

Larval Period: 6 weeks (Blanchard 1923), 18 weeks; variation in larval deveropment time dependent upon pond conditions (Bishop 1941:186).

Home Range/Movement: Unreported.

Food Habits/Preferences: Sma 11 invertebrates, including insects, spiders, earthworms.

Comments: Nocturnal.

Selected References: Bishop 1947, Nei11 1963. 


Age/Size at Sexual Maturity: 4 to 5 years, at total length of about $5-1 / 2$ in $(14 \mathrm{~cm})$ in New York (Bishop 1947:370).

Breeding Period: Mid-October to winter months (Bruce 1972). Annual reproduction cycle (Bruce 1969).

Egg Deposition: April to summer and into the fall (Bruce 1972), female guards eggs (Organ 1961).

No. Eggs/Mass: 9 to 63 (Bruce 1972), 44 to 132 eggs (Bishop 1941:247), 44 to 66 (Organ 1961). Eggs laid in running water under logs and stones, usually in groups, sometimes attached singly.

Time to Hatching: Fal1 (Organ 1961). Hatch late summer, early fall. The young from one clutch may remain near the nest site for several months after hatching (Bruce 1980).

Larval Period: Variable larval period, average of about 4 years. Metamorphosis occurs in late spring and summer (Bruce 1980). Larvae are aquatic.

Home Range/Movement: Unreported.

Food Habits/Preferences: Euryphagic predators--consume aquatic insects and the ir nymph and larval forms, crustaceans, centipedes, earthworms, snails, spiders, millipedes, small frogs and salamanders. Terrestrial insects were $79 \%$ of total prey items in New Hampshire (Burton 1976). Has been found to eat its own larvae (Logier 1952:76). Salamanders comprise 50\% of the diet in the Appalachians (Bruce 1972); salamanders a minor part of diet in New York (Bishop 1941:253). Nocturnal, forages for food among rocks and vegetation in or along stream beds on rainy summer nights. Larvae are generalist feeders. until metamorphosis when they take larger food items (Bruce 1980).

Comments: Formerly named the purple salamander.

Selected References: Bishop 1941, Brandon 1967, Bruce 1972, 1980. 



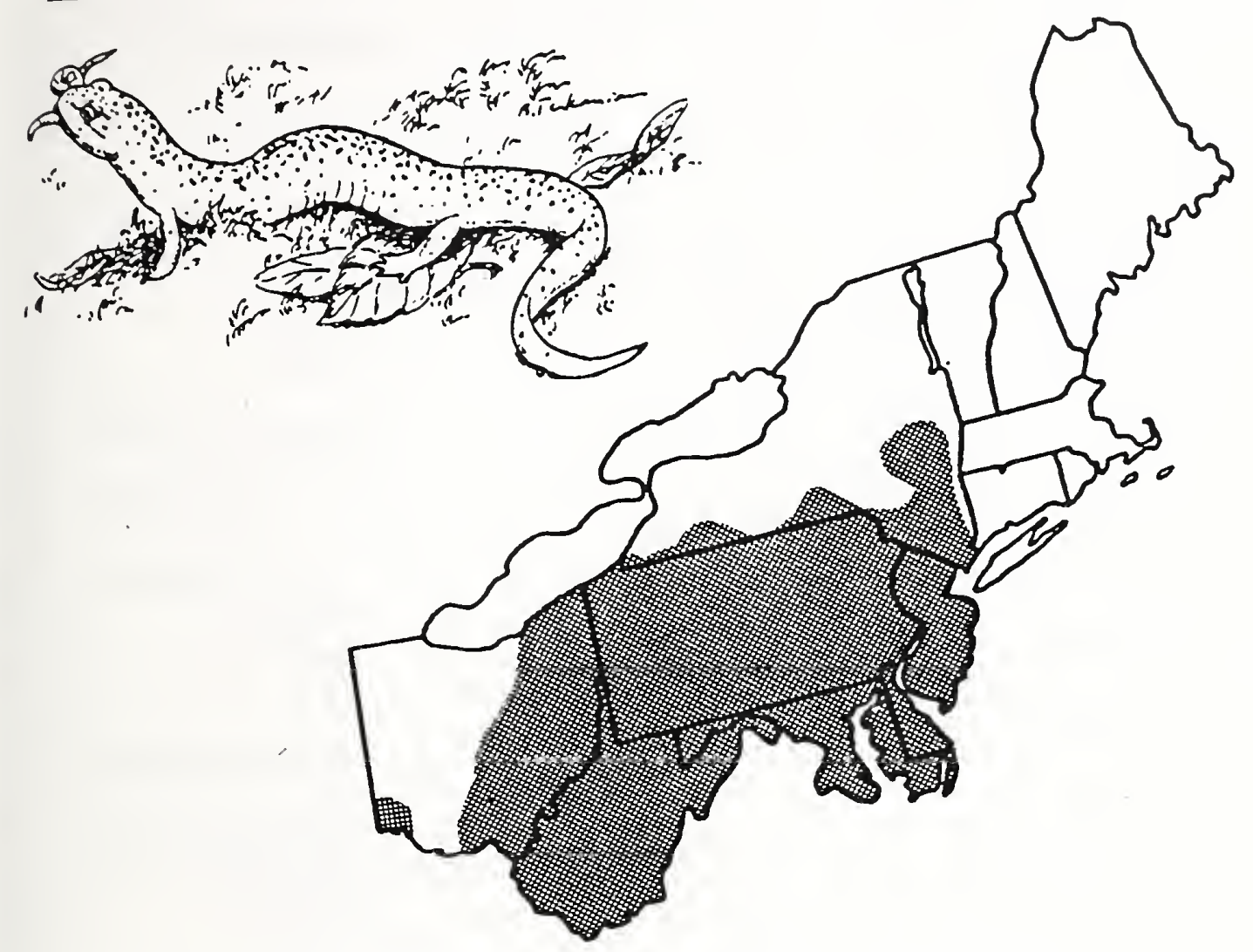

Range: Southern New York to e. Ohio, south to n.e. Mississippi, c. Alabama, Georgia and South Carolina. Disjunct colonies along the Ohio River.

Relative Abundance in the Northeast: Uncommon, abundant south into Maryland and Pennsylvania.

Habitat in the Northeast: Near meadow and woodland streams, springs, swamps, and trickles with cool clear water. Terrestrial habitats include shallow burrows under moss, stones or other debris often far from water. Prefers streams with abundant leaf litter and gravel, sand or rock bottoms. Avoids large swift streams (Martof 1975:167.1). Terrestrial surface dweller in early spring and summer and found in aquatic habitats from late summer through to next spring (Bruce 1978).

Special Habitat Requirements: Aquatic habitats used during winter and for breeding.

Age/Size at Sexual Maturity: Males reach sexual maturity during fourth summer at 45 months, females oviposit at 5 years or older (Bruce 1978). 

Breeding Period: Late June to September (Bruce 1978).

Egg Deposition: Fall months at onset of cooler temperatures. Females with eggs have been found in December, February and April.

No. Eggs/Mass: 50 to 100 eggs (Martof 1975:167.1). Clutch size varies with body size. Eggs laid under submerged stones attached separately or in small clusters. Different females may lay eggs under the same stone. Clusters contain 12 or more eggs (Dunn 1926:277).

Time to Hatching: 58 to 74 days (Bishop 1941:266).

Eggs Hatch: Late fal1 to December (Dunn 1926:277).

Larval Period: About 30 months (Bishop 1925) to 3 years (Babbitt

1937:71), 27 to 31 months, slightly shorter in northern parts of range (Martof 1975:167.1). Larvae inhabit stil1 waters of springs and smal1 streams (Martof 1975:167.1).

Home Range/Movement: Unreported.

Food Habits/Preferences: Earthworms, snails, slugs, spiders, millipedes, water fleas, insects and their larvae, other salamanders (Surface 1913:103). Feed in patches of water weeds. Larval stage feeds on insect larvae, worms and water fleas (Bishop 1925:397).

Comments: During summer months may be found a considerable distance from water.

Selected References: Bishop 1943, 1947; Bruce 1968; Martof 1975. 



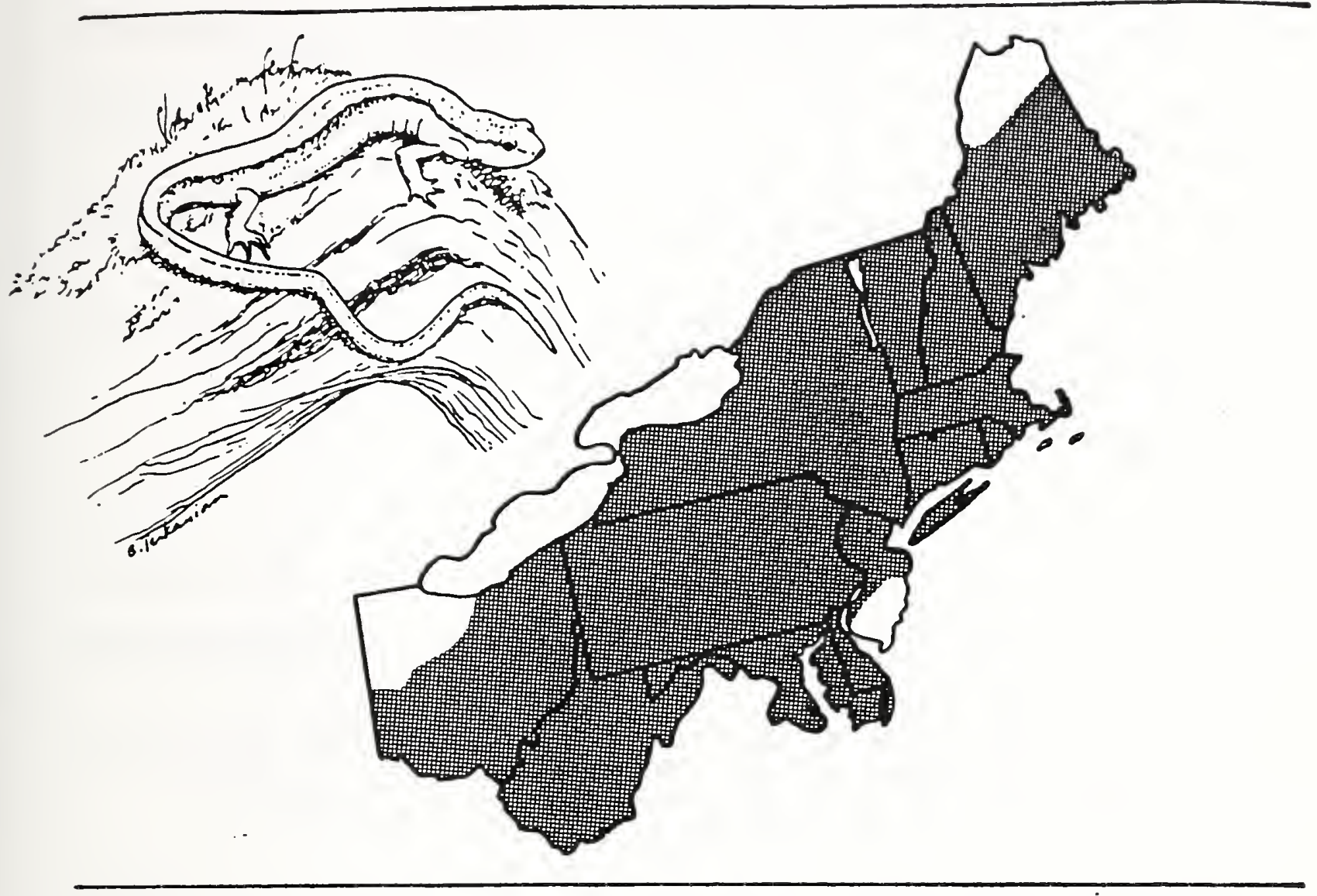

Range: Gaspe Peninsula, Quebec and e. Ontario southwest through Ohio to e. Illinois, south to extreme n.e. Mississippi to Virginia.

Relative Abundance in the Northeast: Common to abundant.

Habitat in the Northeast: Floodplain bottoms to moist forest floors at high elevations to 1,829 $\mathrm{m}$ (6000 ft) (Behler and King 1979:321). Along brooks and streams, boggy areas near springs or seeps. Found under objects at waters' edge in moist soil or in coarse sand and gravel at stream bottoms or edges, leaf litter and crayfish burrows (Ashton and Ashton 1978). In wet woodlands or pastures. Found at considerable distances from water if cover objects are available (M. Stewart, pers. commun.). During wet or humid weather will wander from water courses into moist woods.

Hibernates under water, or remains active in feeding aggregations in springs and cold, flowing streams in New York (Stewart 1956a) and adjacent unfrozen soil (Ashton and Ashton 1978).

Special Habitat Requirements: Streams for breeding. 

Age/Size at Sexual Maturity: The majority mature during the second fall after metamorphos is (Stewart 1956a).

Breeding Period: Autumn and early spring. Breeds in streams with high $\mathrm{pH}$.

Egg Deposition: May to early June, Massachusetts (Johnston and Goldberg 1975).

No. Eggs/Mass: 12 to 36 eggs, average of 18 eggs in Massachusetts (Wilder 1924). Eggs deposited in clusters attached to bottoms of stones or logs in running water. Several females may use the same stone as a nest site, one female remains with eggs until hatching.

Time to Hatching: 1 to 2 months after eggs laid.

Larval Period: 2 or 3 years, aquatic (Wilder 1924).

Home Range/Movement: Average area less than $14 \mathrm{~m}^{2}$ for 20 monitored individuals along a stream in Ohio (Ashton and Ashton 1978).

Food Habits/Preferences: Insects, particularly beetles, beetle larvae, mayflies, stonefly nymphs and dipterans; also spiders, mites, millipedes, sowbugs and earthworms (Hamilton 1932). Most prey are of terrestrial origin (Burton 1976).

Comments: Will travel in the open during wet or rainy nights, rarely during wet days. Adults are extremely agile and when disturbed often escape through a series of rapid jumps.

Selected References: Bishop 1941, Bleakney 1958, Mittleman 1966. 


Egg Deposition: In New Jersey eggs laid underground from January to February (Anderson and Martino 1966). Females have been found with eggs in September in Indiana (Minton 1972:79), November in Maryland (Franz 1964), January in Pennsylvania (Mohr 1943, cited in Minton 1972:79).

No. Eggs/Mass: About 100 eggs (Minton 1972:79). Eggs attached to the underside of submerged stones or suspended above water.

Larval Period: Averages 90 to 100 days with metamorphos is occurring in mid-June in New Jersey (Anderson and Martino 1966). Larvae are aquatic.

Home Range/Movement: Unreported.

Food Habits/Preferences: Insects, especially coleopteran larvae; also spiders, mites, ticks, pseudoscorpions and some vegetative material. Less frequently takes centipedes, millipedes, earthworms and isopods (Anderson and Martino 1967).

Comments: Nocturnal but also active on rainy days. In limestone areas of $n$. New Jersey, this species is the last salamander to emerge in the spring--commonly found in mid-April (Anderson and Martino 1966). Life history details are not well known.

Selected References: Bishop 1941, 1947; Anderson and Martino 1966. 



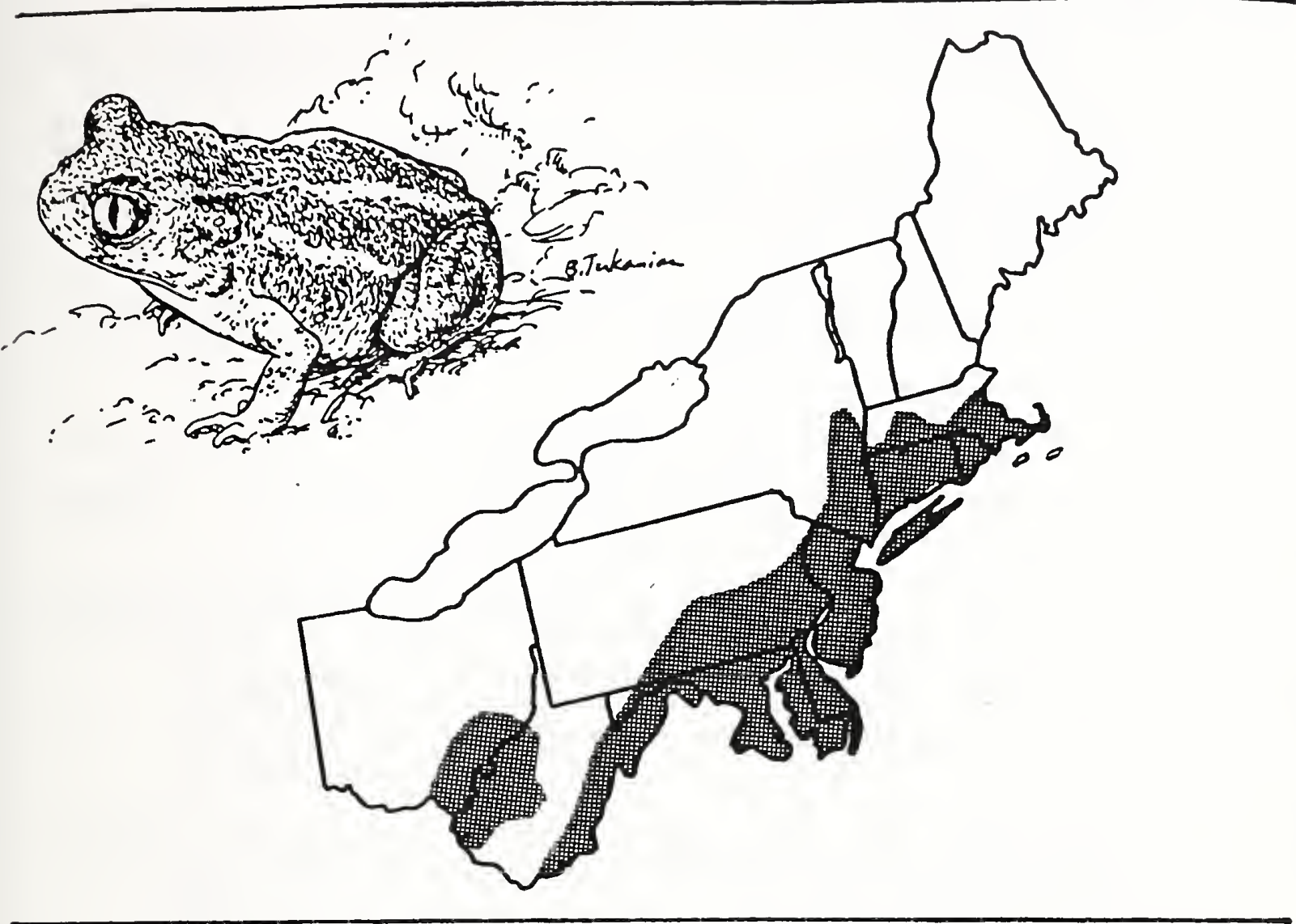

Range: Southeastern Massachusetts extending to New York and s.e. Missouri, south to $e$. Louisiana and Florida. Not found in the higher elevations of the Appalachians or the Everglades of Florida.

Relative Abundance in the Northeast: Rare, common south into New Jersey, Maryland and Delaware.

Habitat in the Northeast: In dry sandy or loose soils in sparse shrub growth or open forest areas. Terrestrial and subterranean, only enters water to breed, usually in temporary rain pools. Prefers forest areas with leaf litter (Pearson 1955). In oak-hickory Savannah in Oklahoma, in farmland areas in Connecticut River Valley, Massachusetts and pitch-pine scrub oak dunes in New York (Stewart and Rossi, unpubl. ms.). Colonies occur along floodplains or major rivers. Emerge in spring from hibernation when soil moisture is sufficient.

Special Habitat Requirements: Sandy soils, temporary pools for breeding. 

Age/Size at Sexual Maturity: During second year after metamorphosis, males at 15 months, females at 19 months (Pearson 1955).

Breeding Period and Egg Deposition: Usually April or May, extending into August; breeding is initiated by a heavy rainfall (Gosner and Black 1955). Breeds in congregations of many individuals if population is high. Usually a one-night phenomenon.

No. Eggs/Mass: 1,000 to 2,500 eggs in masses of 6 to 110 in irregular bands in or around plants of temporary water. Eggs are very adhesive.

Time to Hatching: 5 to 15 days (01iver 1955:236).

Tadpoles: Late broods transform in 16 to 20 days (Gosner and Black 1955), 48 to 63 days for early broods (Driver 1936).

Home Range/Movement: Mean home range about $10 \mathrm{~m}^{2}\left(108 \mathrm{ft}^{2}\right)$ in $\mathrm{n}$. Florida, for $90 \%$ of captures average home range was about $6.2 \mathrm{~m}^{2}\left(67 \mathrm{ft}^{2}\right)$. 0ccupy one or several underground burrows within home range (Pearson 1955). Maximum dispersal distances of $9.8 \mathrm{~m}(32 \mathrm{ft}$ ); individuals were recaptured in the same home ranges after 5 years (Pearson 1957).

Food Habits/Preferences: Flies, spiders, crickets, caterpillars, true bugs, other ground-dwelling arthropods, earthworms and snails. Moths are eaten when they can be caught (Bragg 1956:36).

Tadpoles are planktonic feeders for the first few days (Richmond 1947), later becoming carnivorous and sometimes even cannibalistic.

Comments: Nocturnal, peaks of activity occur just after sundown and before sunrise. Fossorial; individuals have remained in burrows an average of 9.5 days at a time, emerging to feed (Pearson 1955). Can remain underground for weeks or months during dry periods. As evidence of the spadefoot's secretive and nocturnal habits, there was a total of 16 reported sightings from 1811 to 1936 in the n.e. part of its range (Ball 1936, cited in Bragg 1965:51).

Selected References: Ball 1936, Pearson 1955, Bragg 1965, Wasserman 1968. 



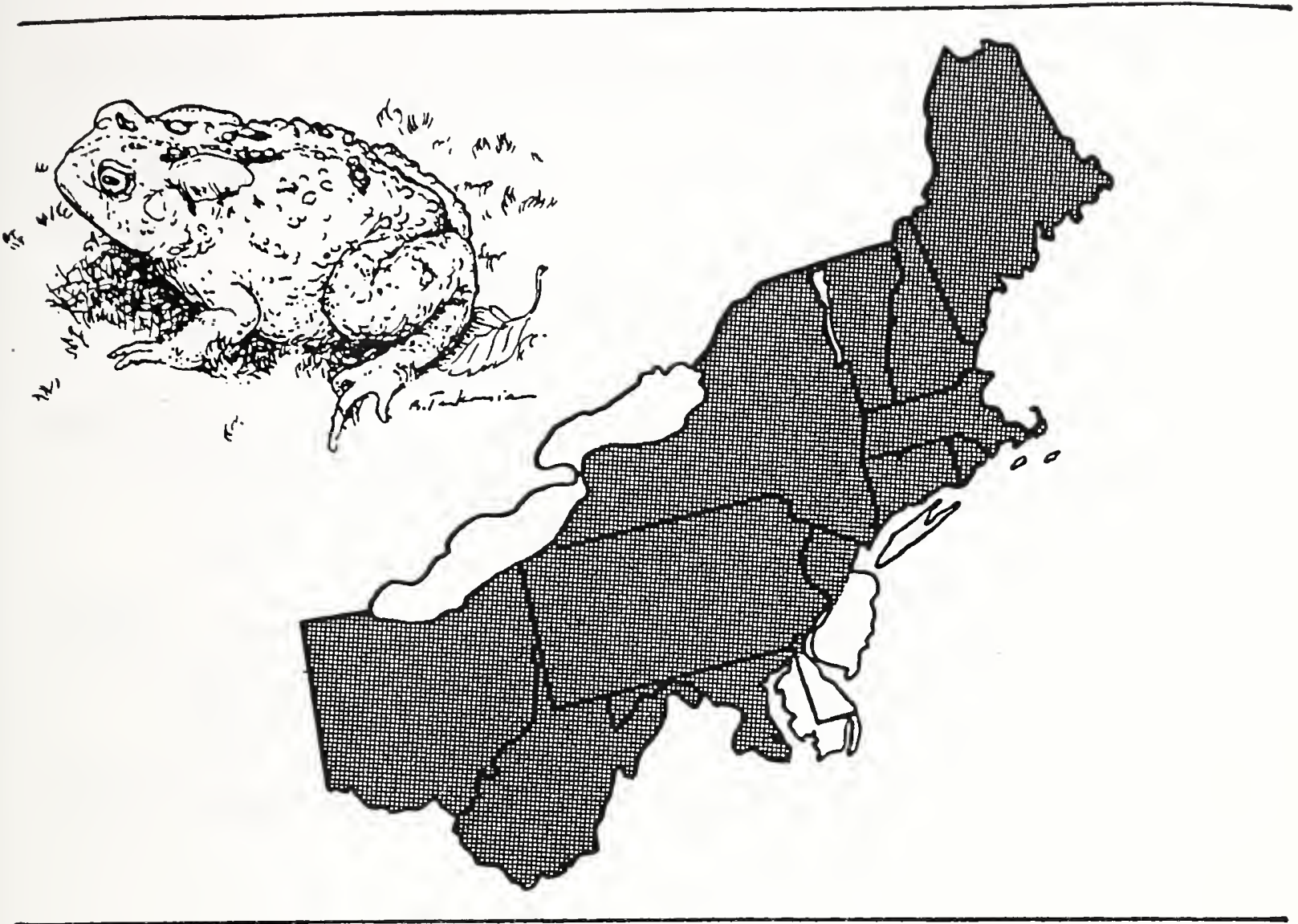

Range: Nova Scotia and the Gaspê Peninsula west through c. Ontario to Lake Winnipeg, south to e. Kansas, c. Indiana, c. Alabama and c. North Carolina.

Relative Abundance in the Northeast: Common.

Habitat in the Northeast: Found in almost any habitat: gardens, woods, yards with cover, damp soil and a food supply. Sea level to mountain elevations. Usually in moist upland woods.

Special Habitat Requirements: Needs shallow water for breeding. Hibernates in burrows underground to 12 in $(30.5 \mathrm{~cm})$ deep (01iver 1955:122) from October to late March or April.

Age/Size at Sexual Maturity: 3 to 4 years (Dickerson 1969:72), 2 to 3 years (HamiTton 1934).

Breeding Period and Egg Deposition: Early April to July, peak in late ApriT in the Northeast. Travels to breeding ponds at night in large numbers (Maynard 1934). 

No. Eggs/Mass: 4,000 to 12,000 eggs (Dickerson 1969:67). Laid in long curling strings amidst aquatic vegetation.

Time to Hatching: About 3 to 12 (average 4) days.

Tadpoles: 5 to 10 weeks.

Home Range/Movement: Exhibits homing behavior by returning to breeding sites; 264 individuals used the same site annually in Ontario (01dham 1966).

Food Habits/Preferences: Terrestrial arthropods, including insects, sowbugs, spiders, centipedes and millipedes. Slugs and earthworms are other invertebrate foods. Some vegetable matter is taken accidentally. Food species determined by availability (Hamilton 1954). Feeds from twilight through the evening hours.

Comments: Most active during evening hours. May bask (M. Stewart, L. White, pers. observ.), but will seek cover during the heat of the day. Calls and breeds during the day at the peak of breeding season ( $T$. Tyning, pers. commun.).

Selected References: Wright and Wright 1949, Hamilton 1954. 



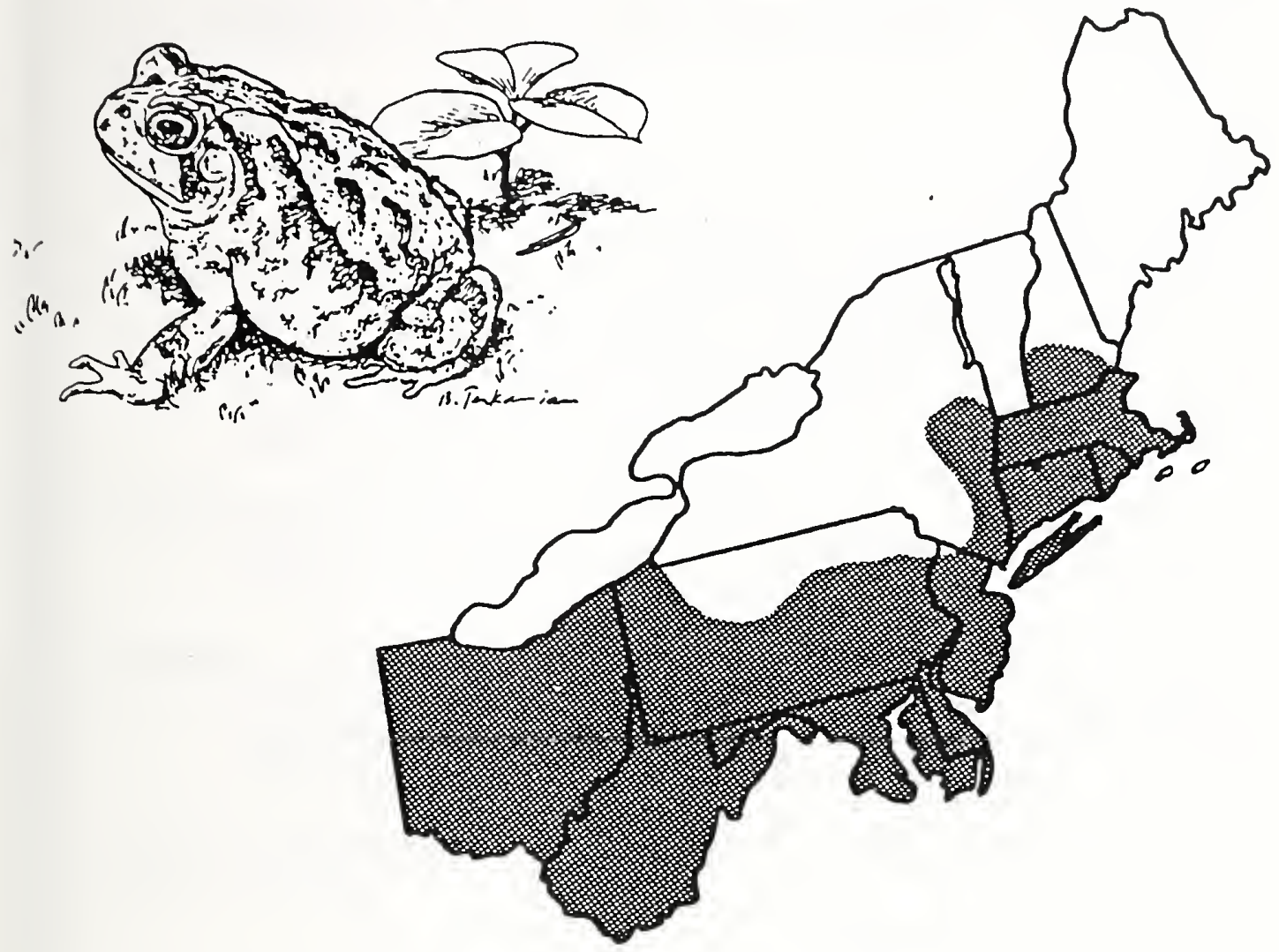

Range: Southern New England west to $c$. Pennsylvania, the $n$. shore of Lake Erie and e. shore of Lake Michigan south to Missouri, e. Oklahoma, Texas, c. Georgia and South Carolina.

Relative Abundance in the Northeast: Uncommon but locally abundant.

Habitat in the Northeast: Prefers areas with sandy soil--shorelines, river valleys, beaches and roadside areas. Usually found in lowland areas, but frequently in pine and oak forests, gardens, lawns and fields. Hibernates in burrows to $3 \mathrm{ft}(0.9 \mathrm{~m})$ deep from early fall to late spring (May in Connecticut).

Special Habitat Requirements: Sandy soils, shallow water for breeding. Age/Size at Sexual Maturity: Probably breeds during third year (Stille 1952).

Breeding Period and Egg Deposition: Late April to May extending to mid-August ( 2 to 4 weeks Tater than Bufo a. anericonus). Shallow water of pools, lake margins, ditches, etc. necessary for breeding. 

No. Eggs/Mass: Up to 8,000 eggs laid in long strings in aquatic vegetation (Wright and Wright 1949:212).

Time to Hatching: About 1 week.

Tadpoles: 40 to 60 days, usually transform mid-summer.

Home Range/Movement: Average distances between captures ranged from 22 to $32 \mathrm{~m}$ during a 3 -year period on a golf course in Connecticut (Clarke 1974). Night movements of 200 to $700 \mathrm{ft}$ $(61$ to $213 \mathrm{~m}$ ) or more to reach waters' edge (Lake Michigan). Toads usually found within $100 \mathrm{ft}(30.5 \mathrm{~m})$ of previous capture point (Stille 1952).

Food Habits/Preferences: Chiefly ground-dwelling insects, particularly ants and beetles; also consumes earthworms, spiders, snails and slugs.

Comments: During evening hours may move to edge of water to replenish body moisture (Stille 1952). May be active during the day, but typically crepuscular (Minton 1972:95). Activity periods vary with populations, mostly nocturnal in Connecticut (Clarke 1974).

Selected References: Wright and Wright 1949, Logier 1954, Clarke 1974. 



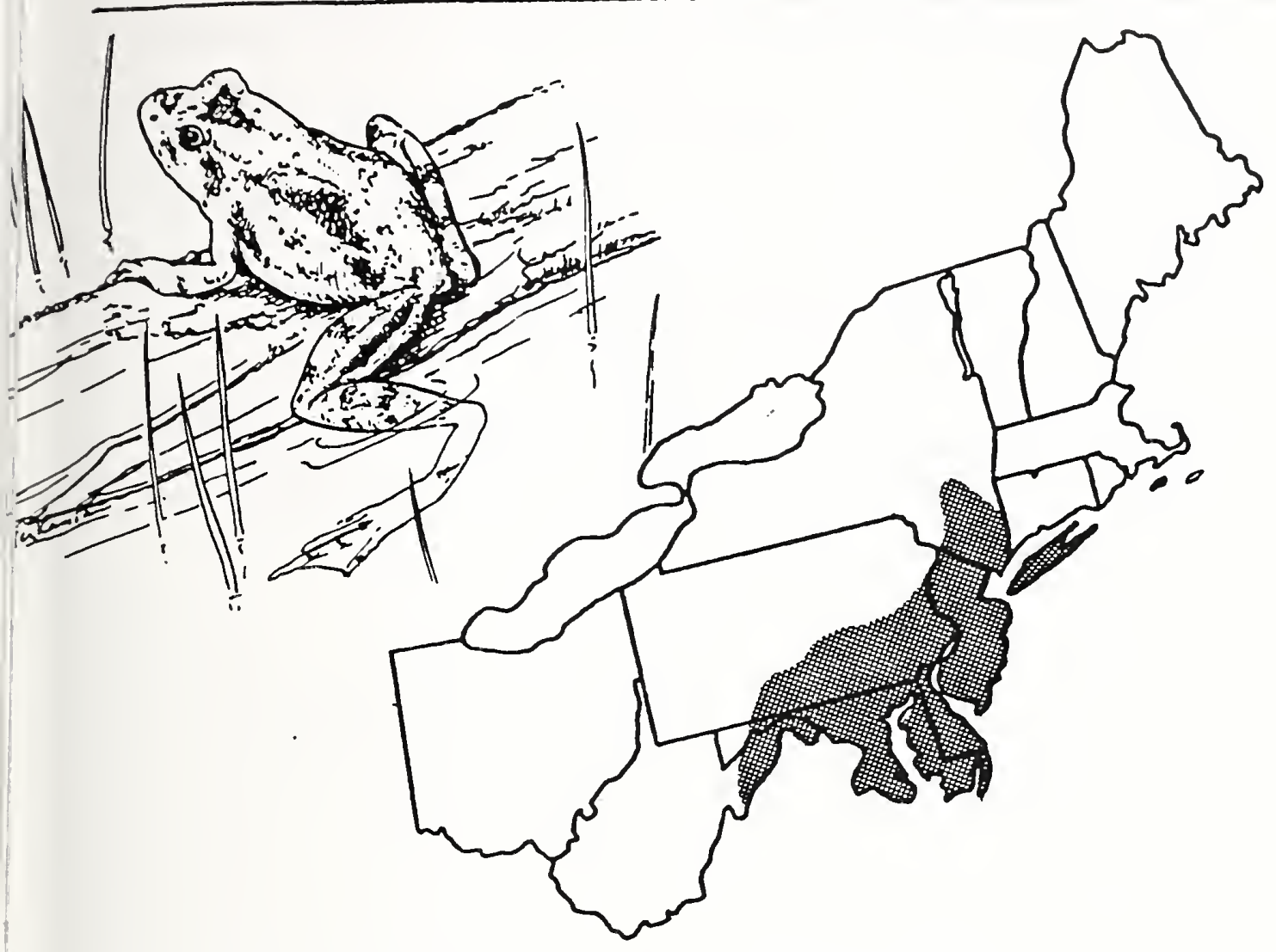

Range: Southern New York and Long Island through s.e. Pennsylvania, Tennessee and $\mathrm{s}$. Arkansas to e. Texas, east through the Florida panhandle to n.e. North Carolina.

Relative Abundance in the Northeast: Uncommon.

Habitat in the Northeast: Shallow water with abundant shoreline weeds or aquatic vegetation, preferably in strong sun. Prefers algae-filled water courses (N. B. Green, pers. observ.). Also occurs on sand bars, in swamps, and at the shores of meandering, slow-moving streams; avoids deep water. Semi-hibernates from November to mid-March under stones and leaves at waters' edge. Active on warm days.

Special Habitat Requirements: Emergent or shoreline vegetation in full sun. Age/Size at Sexual Maturity: Breeds in second spring (Burkett 1969). Breeding Period and Egg Deposition: April to July. No. Eggs/Mass: 250 eggs (Smith 1956:89), attached to aquatic vegetation in sma 11 masses of about 6 eggs. 

Time to Hatching: 4 days, longer in cold temperatures.

Tadpoles: 50 to 90 days (Cochran 1961:114), transform late July to September (Logier 1952:90).

Home Range/Movement: Unreported.

Food Habits/Preferences: Insects comprise $75 \%$ of prey items, particularly aquatic beetle larvae, midges, muscoid flies and springtails; spiders $25 \%$ (Jameson 1947$)^{\star}$.

Comments: Non-arboreal and diurnal. May move between pools at night. Selected References: Wright and Wright 1949, Logier 1952, Burkett 1969.

*Acris crepitons in e. Kansas. 



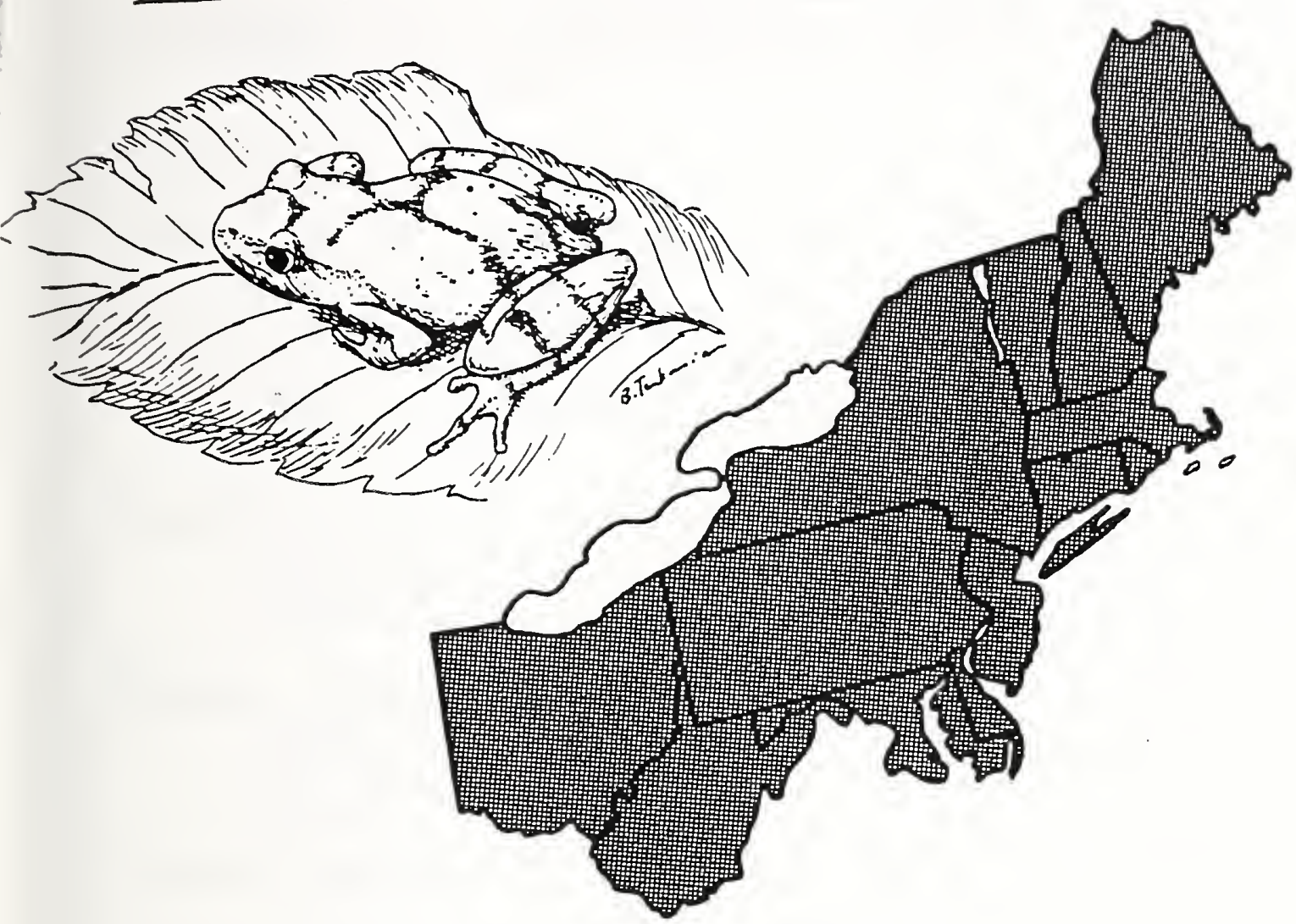

Range: Nova Scotia, the Gaspé Peninsula and Quebec to the s. tip of Hudson Bay through Ontario to Lake Winnipeg, south to e. Texas and throughout the e. U.S. except Florida and S. Georgia.

Relative Abundance in the Northeast: Common to abundant.

Habitat in the Northeast: Marshy or wet woods, second growth woodlots, sphagnum bogs, non-wooded lowlands, near ponds and swamps. Found on the ground or burrowed into the soil. Breeds in permanent or temporary water, usually woodland ponds with aquatic debris. Found in cool moist woods after breeding (M. Stewart, pers. observ.). Hibernates on land during late November to January or early spring, under moss and leaves.

Special Habitat Requirements: Pools for breeding.

Age/Size at Sexual Maturity: Early in second year at about $20 \mathrm{~mm}$ (Delzel1 1958).

Breeding Period and Egg Deposition: Early March to June (in the North). 

No. Eggs/Mass: 800 to 1,000 eggs (Wright 1914:16). Laid singly near the bottom of shallow weedy ponds, attached to submerged plants (01iver 1955:236).

Time to Hatching: 6 to 12 days.

Tadpoles: 90 to 100 days (Wright 1914:42). Usually transform during July (Wright and Wright 1949:314).

Home Range/Movement: In s.e. Michigan, home range diameters ranged from 4 to $18 \mathrm{ft}(1.2$ to $5.5 \mathrm{~m})$, established around forest debris and vegetation; average daily travel was 20 to $130 \mathrm{ft}(6.1$ to $39.6 \mathrm{~m})$ reported by Delzell (1958).

Food Habits/Preferences: Small non-aquatic insects: preferably ants, flying bugs, beetles, flies, springtails and spiders, also mites, ticks and small snails. Foods taken probably reflect availability, catchability and size, rather than preference (Oplinger 1967).

Comments: Young frogs terrestrial in first year (Delzell 1958). May move long distances from breeding areas in sumer and fall, single calls heard from woods, shrubby openings, far from water (M. Stewart, pers. observ.).

Selected References: Wright and Wright 1949, Logier 1952, Delzell 1958. 

Hyla v. versicolor, Hyla v. chrysoscelis*

Hylidae

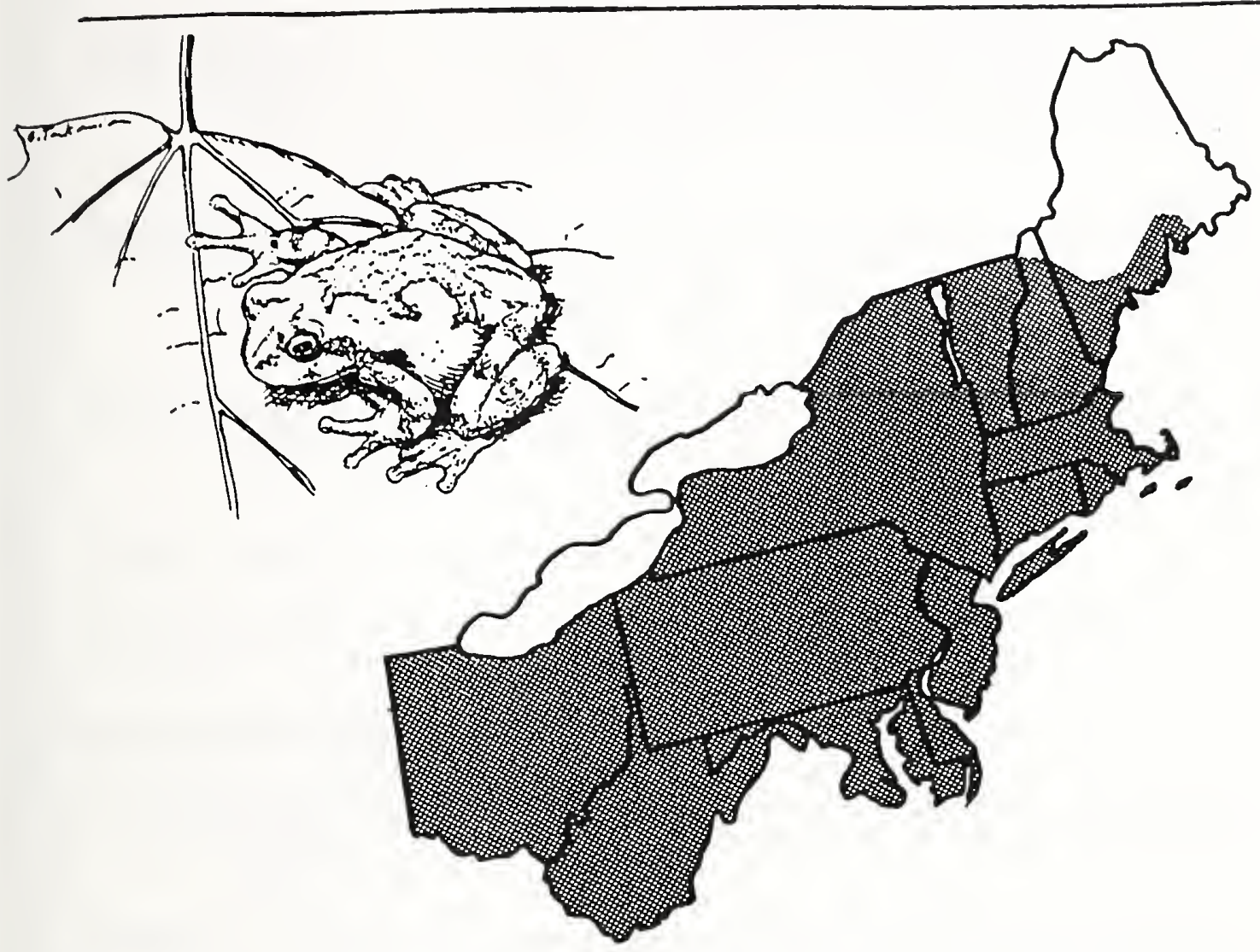

Range: Eastern U.S. and s.e. Canada from S. Maine to Manitoba and south through $c$. Texas and the Gulf States to c. Florida.

Relative Abundance in the Northeast: Common.

Habitat in the Northeast: Forested regions with small trees, shrubs and bushes near or in shallow water. Often found on moss or lichen on bark of old trees. Will breed in temporary pools or permanent water, swamps, bogs, ponds, weedy lakes and roadside ditches, but breeding sites are extremely variable. Commonly inhabit moist areas in hollow trees, under loose bark, or in rotted logs during summer months (Smith $1961: 93$ ).

Special Habitat Requirements: Aquatic sites for breeding.

Age/Size at Sexual Maturity: Undocumented.

*Two species are identical in appearance and can only be positively identified in the field by their voices. Both considered gray treefrogs (Jaslow and Vogt 1977). 

Breeding Period: Early April to July or August, Maryland (Fellers 1979). May to August (Martof et al. 1980:116). Season varies with latitude (Smith 1961:93). Peak in early May, Ithaca, New York (Wright 1914:44).

Egg Deposition: General1y 20 to 35 days between first appearance and first eggs (Wright 1914:47). April to August, loosely attached to vegetation on the surface of shallow water (Martof et al. 1980:116).

No. Eggs/Mass: Total of 1,800 to 2,000 eggs (Wright 1914:49). Packets of 10 to 40 eggs (Martof et al. 1980:116), or 4 to 25 eggs (Smith 1961:93).

Time to Hatching: 4 to 5 days (01iver 1955:236).

Tadpoles: 50 to 60 days, shorter periods in warmer areas. Transform late in June to September.

Home Range/Movement: Unreported.

Food Habits/Preferences: Small insects, spiders, plant lice, mites, snails. Forage in vegetation and on the ground (Martof et al. 1980:1i6).

Comments: Most active during evening hours when vocal both during and out of breeding season. Rarely found outside of breeding period. Able to change color from gray to green. Young are emerald green. Single calls heard occasionally in summer during humid days, often before a storm. $H$. versicolor is a triploid species with 48 chromosomes, $B$. chrysoscelis has 24 chromosomes (Martof et al. 1980:115).

Selected References: Wright and Wright 1949, Logier 1952, Martof et a1. 1980. 



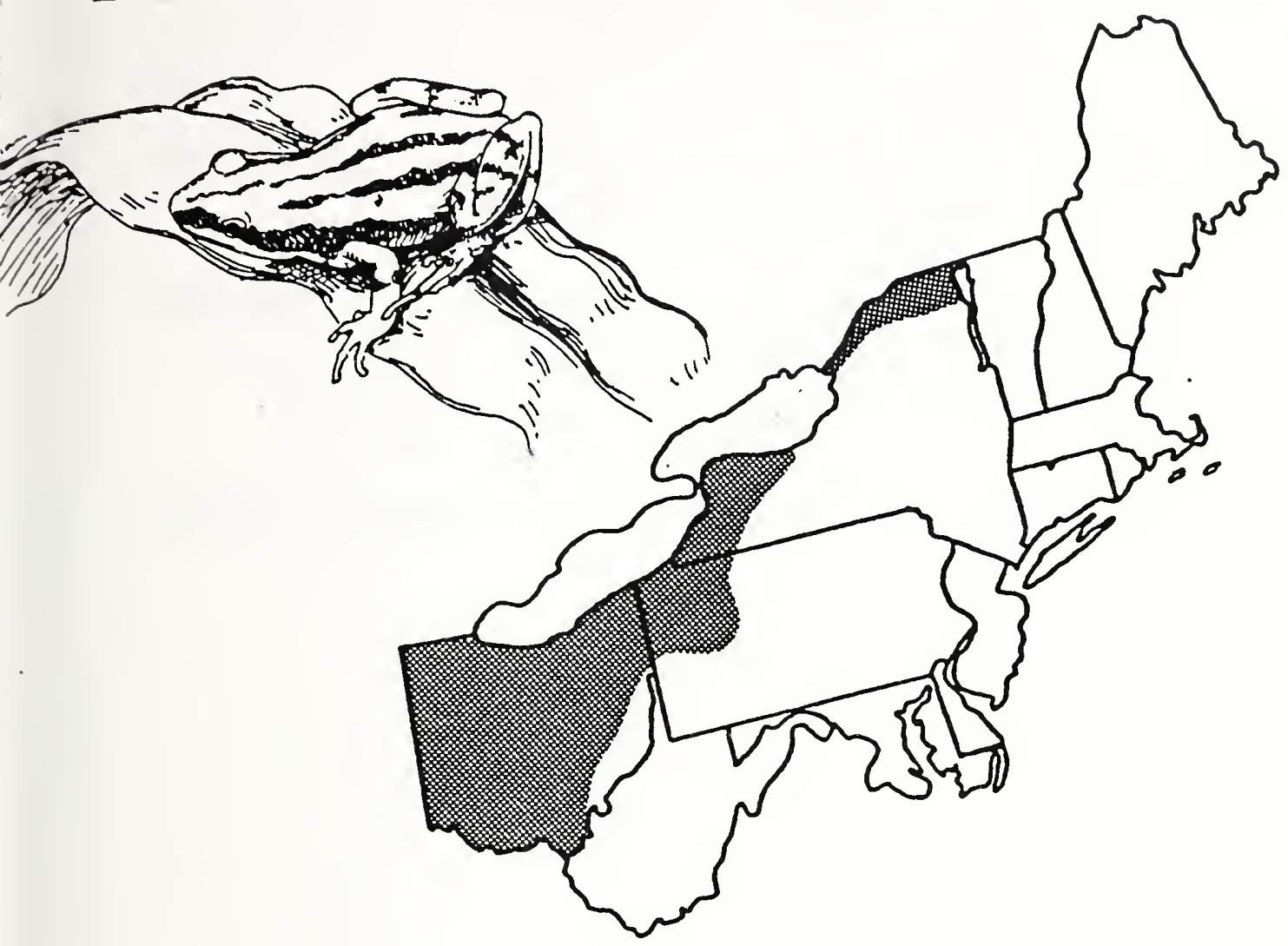

Range: Extreme s. Quebec and Ontario, n. and w. New York and west through c. Minnesota to w. Nebraska, south to c. Oklahoma, s.w. Ohio and n.w. Pennsylvania. Disjunct populations in Arizona and New Mexico.

Relative Abundance in the Northeast: Uncommon.

Habitat in the Northeast: Pastures, fields, agricultural lands, swamps, damp meadows in low shrubs and grass. Found within cities and towns in unpolluted areas. Hibernates under forest floor debris or in underground burrows. Has been found up to $10,000 \mathrm{ft}(3,048 \mathrm{~m})$ elevations in the Rocky Mountains.

Special Habitat Requirements: Shallow water with emergent vegetation. Age/Size at Sexual Maturity: Unreported.

Breeding Period: March to June, peak in late March (Illinois, Indiana). No. Eggs/Mass: 500 to 1,500 eggs, in loose masses of 20 to 100 (Wright and Wright 1949:255). 

Time to Hatching: 4 to 10 days (Minton 1972:103).

Tadpoles: 40 to 90 days (Wright and Wright 1949:255).

Home Range Size: For 9 males in a mixed woodland-grassland-farmland habitat in Indiana, home range averaged $2,117 \mathrm{~m}^{2}$, and ranged from $641 \mathrm{~m}^{2}$ to $6,024 \mathrm{~m}^{2}$ (Kramer 1974).

Food Habits/Preferences: Small arthropods, including beetles (adults and larvae), spiders, caterpillars and amphipods are the most common food items. Less frequently, adult moths, leaf hoppers, small flies, wasps, snails and annelids are taken (Minton 1972:104).

Selected References: Wright and Wright 1949, Smith 1961, Minton 1972. 



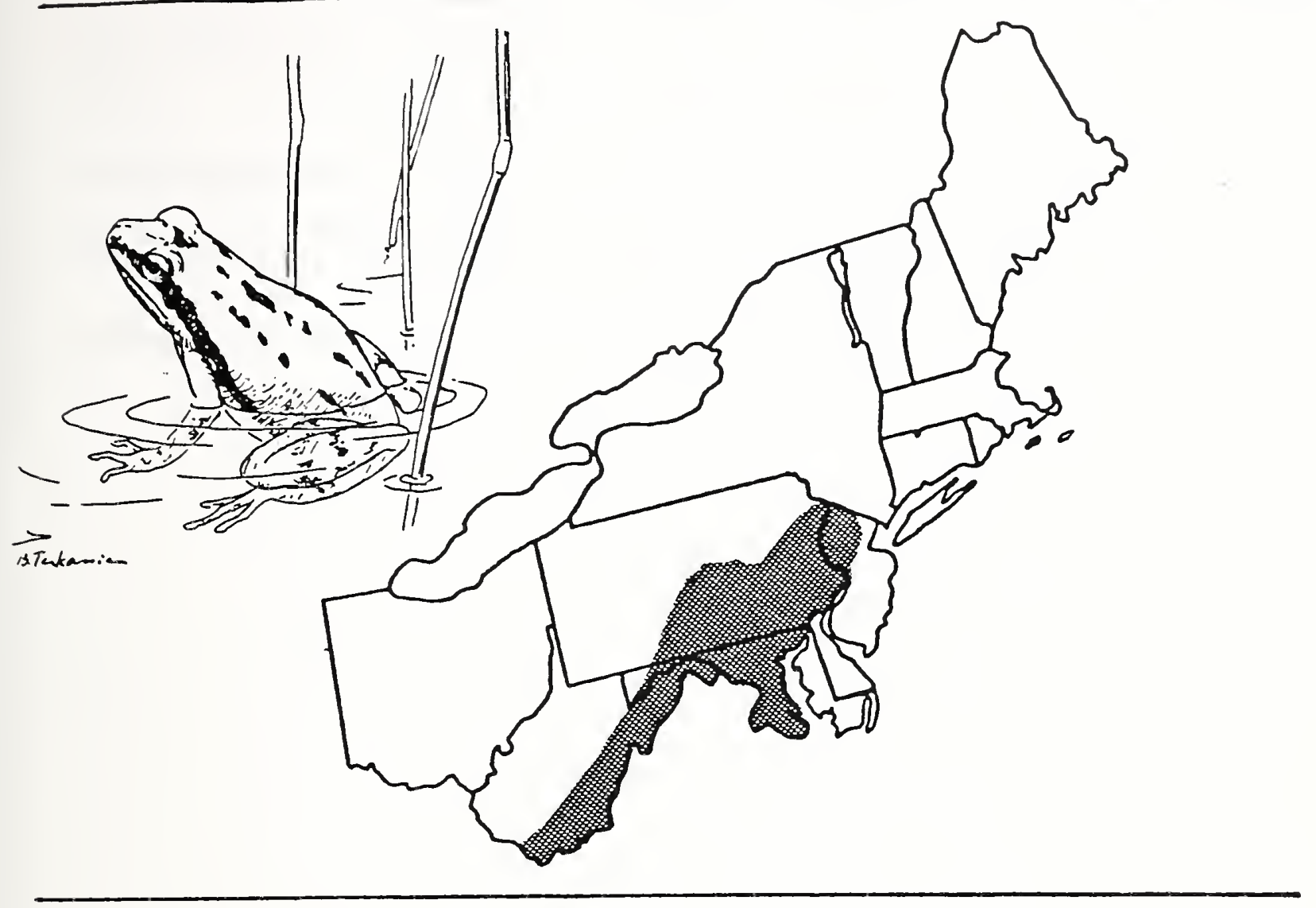

Range: Northern New Jersey and c. Pennsylvania west through Tennessee to e. Texas extending east to the Florida panhandle, c. Georgia and $c$. parts of the Carolinas. Absent from much of Coastal Plain.

Relative Abundance in the Northeast: Uncommon.

Habitat in the Northeast: Shallow edges of ponds with mats of vegetation, moss or hummocks; also in marshes, swamps, bogs (Wright and Wright 1949:244). Most breeding ponds are shallow with dense vegetation (N. Green, pers. observ.). Found in cool, damp woods after breeding season (Brimley 1939).

Special Habitat Requirements: Semi-permanent pools for breeding.

Age/Size at Sexual Maturity: Unreported.

Breeding Period: February to mid-May, peak in mid-March.

No. Eggs/Mass: About 1,000 eggs laid in irregular clusters attached to underwater stems (Martof et al. 1980:127). 



$$
\text { Upland Chorus Frog }
$$

Time to Hatching: A few days.

Tadpoles: 50 to 60 days (Wright and Wright 1949:247).

Home Range/Movement: Unreported.

Food Habits/Preferences: Small arthropods, including insects, millipedes and small crustaceans; slugs are also taken.

Selected References: Wright and Wright 1949, Smith 1961. 



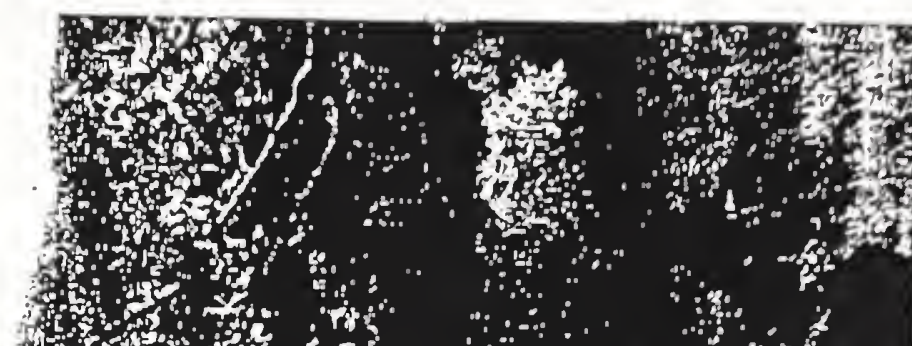
the G art? If 가의.

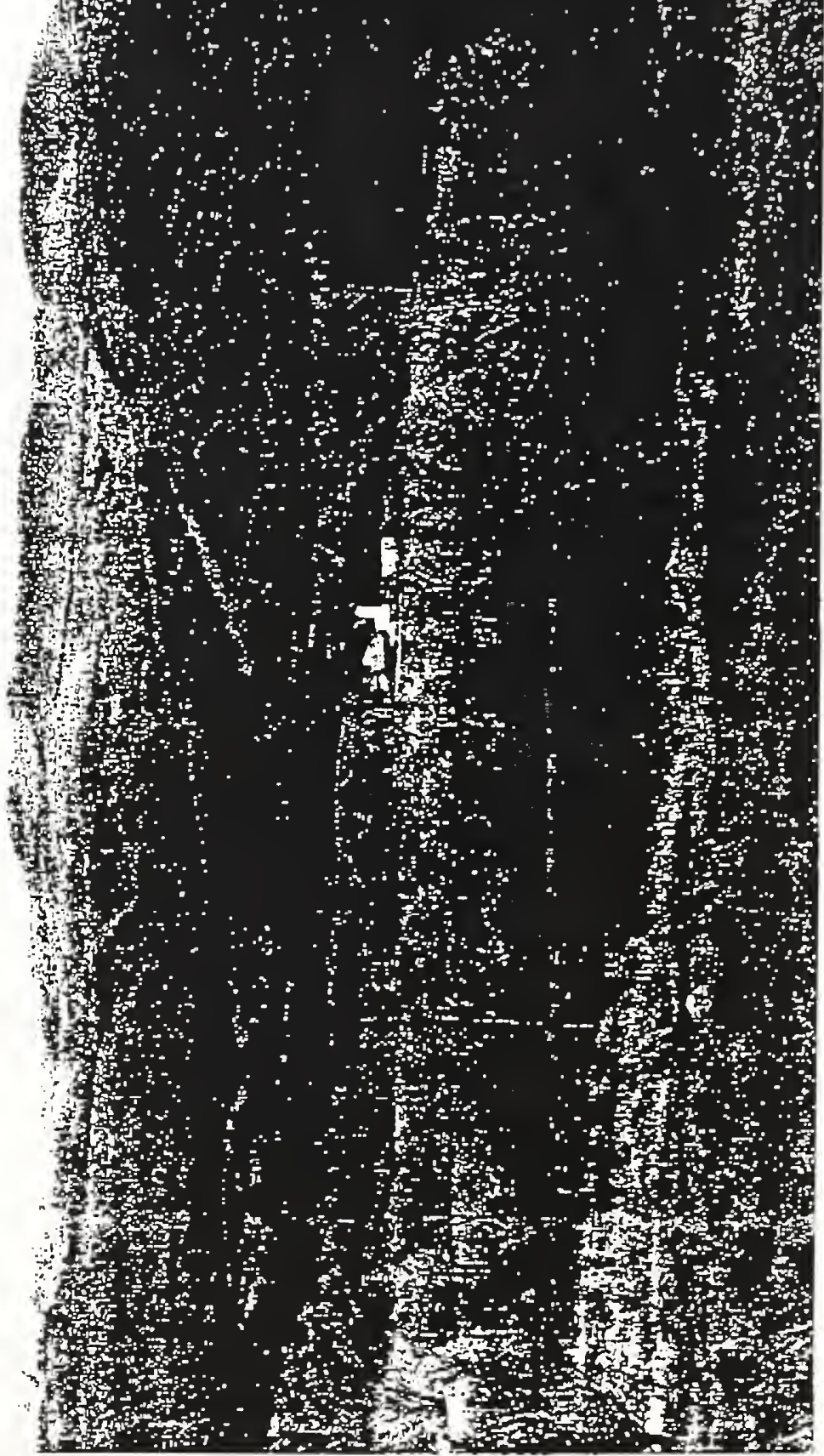


. 


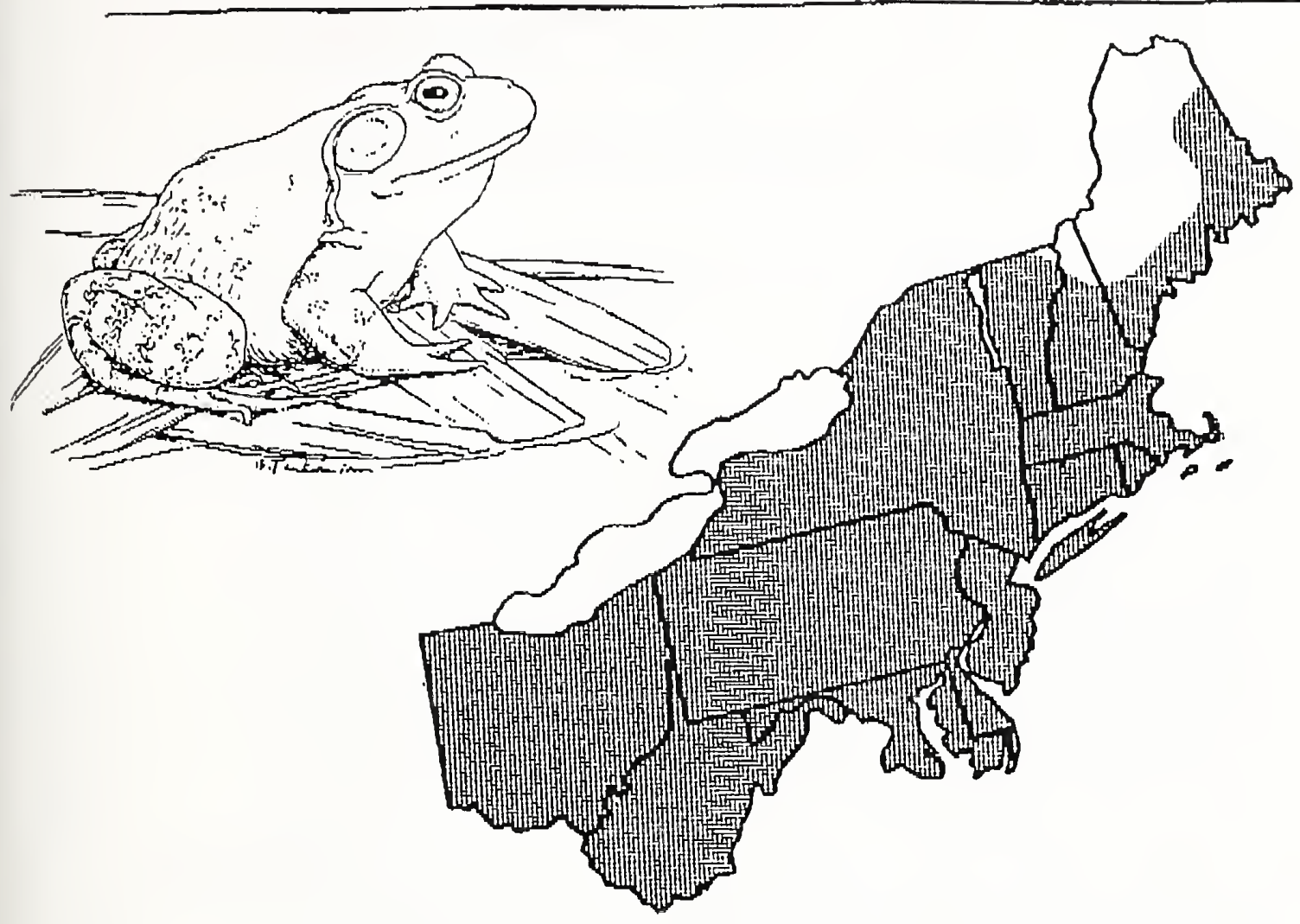

Range: Nova Scotia west to Wisconsin, south through the Great Plains to e. Colorado, Texas and n.e. Mexico; throughout the e. U.S. except s. Florida and parts of $n$. Maine. Introduced in Caljfornia and British Columbia.

Relative Abundance in the Northeast: Common, but formerly more abundant.

Habitat in the Northeast: Near shorelines of large bodies of water with emergent vegetation, lakes, river oxbows. Highly aquatic. Tend to remain in same pools for the summer months if water level is stable (Raney 1940). Will occupy floating logs far from shore. Breed close to shore lines in areas sheltered by shrubs (Raney 1940). Hibernates under water in mud and leaves about mid-October, emerges 1ate February to March, May in New York (Wright 1914:78).

Special Habitat Requirements: Deep permanent water and emergent vegetation. Age/Size at Sexual Maturity: In fourth or fifth year. 
Breeding Period and Egg Deposition: Late May to July (in the North), peak in July.

No. Eggs/Mass: 12,000 to 20,000 eggs (Wright 1914:82). Eggs 1aid in floating films of jelly in water of lakes, quiet streams and ponds.

Time to Hatching: 5 to 20 days (01iver 1955:237). Often 4 days or less (Wright 1914:83).

Tadpoles: For 2 to 3 winters.

Home Range/Movement: Average distance traveled in summer, 200 to 300 $\mathrm{ft}(61$ to $91 \mathrm{~m}$ ) in a woodland lake and pond in New York (Raney 1940, Ingram and Raney 1943). Evening movement of 200 to $700 \mathrm{ft}$ $(61$ to $213 \mathrm{~m}$ ) to water in Michigan (Stille 1952). Home range of 131 bullfrogs in an Ontario pond had an average mean activity radius of $8.6 \mathrm{ft}(2.6 \mathrm{~m})$ with minimum and maximum movements of $2.0 \mathrm{ft}(0.6 \mathrm{~m})$ and $37.1 \mathrm{ft}(11.3 \mathrm{~m})$ respectively (Currie and Bellis 1969). Males defend territories during breeding season. In a Michigan study (Emlen 1968), the average distance between males within a chorus was $17.8 \mathrm{ft}(5.4 \mathrm{~m})$, implying an average minimum territorial radius of approximately $9 \mathrm{ft}(2.7 \mathrm{~m})$.

Food Habits/Preferences: Any available small anima1s; fish, other frogs, salamanders, newts, young turtles, snakes, smal1 birds, mice, crayfish, insects, snails and spiders. Also cannabalistic. Feeds among the water weeds, an indiscriminate and agressive predator.

Comments: The bullfrog has become rare in many areas, presumably due to toxic effects of DDT and other pollutants (M. Stewart, pers. commun.).

Selected References: Wright and Wright 1949, Logier 1952. 
. 


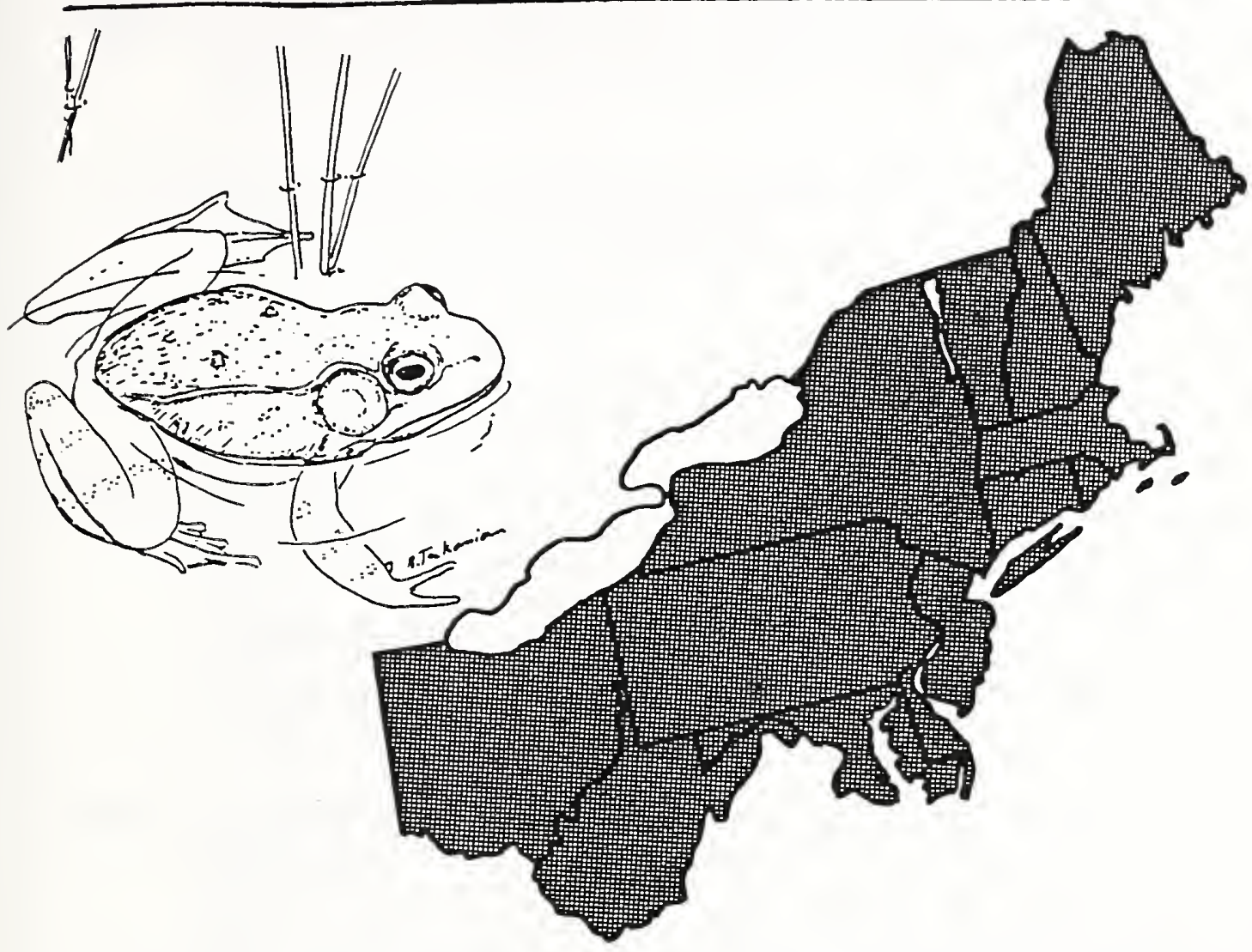

Range: Nova Scotia through Quebec and s. Ontario to c. Minnesota, south to e. Oklahoma and east to $\mathrm{n}$. Georgia and South Carolina. Absent from c. Illinois.

Relative Abundance in the Northeast: Common.

Habitat in the Northeast: Riparian, inhabits margins of shallow permanent or semi-permanent fresh water, shores and banks of lakes and ponds, creeks, woodland streams, limestone quarry pools, springs, vernal pools, moist woodlands near water. Seldom more than a few meters from the water. Young often found in semi-permanent water. Hibernates underground or underwater from October until March, usually within its home range (Martof 1953b). May be active on warm winter days.

Special Habitat Requirements: Riparian areas.

Age/Size at Sexual Maturity: Males sexually active the season following metamorphosis when 60 to $65 \mathrm{~mm}$ long; females mature during the second or third year when 65 to $75 \mathrm{~mm}$ long (Martof 1956). Some females reached maturity at $90 \mathrm{~mm}$ at Cranberry Lake, New York (M. Stewart, pers. commun.). Some may not breed until the second year after transformation (Wells 1977). 

Breeding Period and Egg Deposition: April to August, peak in mid-May, varies with locality. The same female may double-clutch (Wells 1976).

No. Eggs/Mass: 3,500 to 4,000 eggs (Wright 1914:16), to 5,000 (Pope 1944). Eggs deposited in floating masses of jelly in permanent water attached to underwater twigs and stems.

Time to Hatching: Unreported.

Tadpoles: 1 to 2 years. Less than 1 year in southern parts of range . May transform in same season eggs are laid (Martof 1956).

Home Range/Movement: Varied from $20 \mathrm{~m}^{2}$ to $200 \mathrm{~m}^{2}$ with an average of $61 \mathrm{~m}^{2}$ in s. Michigan near a stream and lake; daily movements were less than $10 \mathrm{~m}$ for $80 \%$ of the 824 individuals recaptured (Martof 1953b). During breeding season, males maintained a 2 to $3 \mathrm{~m}$ distance between each other (Martof 1953a). Territory size dependent upon cover density, 1 to $1.5 \mathrm{~m}$ between males in areas of dense cover. Territories with diameters of 4 to $6 \mathrm{~m}$ defended in open areas in New York (Wells 1977).

Food Habits/Preferences: Terrestrial feeders among shoreline vegetation. Insects and their larvae, worms, small fish, crayfish and other crustaceans, newts, spiders, small frogs and mollusks are taken. Beetles, flies, grasshoppers and caterpillars constituted over $60 \%$ of food items (Hamilton 1948). Terrestrial beetles are the most important food item (Stewart and Sandison 1972). Tadpoles are herbivorous.

Comments: Found in or at edge of water during daylight hours; evening hours are spent along the banks feeding or in water defending territories (We11s 1977).

Selected References: Wright and Wright 1949; Logier 1952; Martof 1953b, 1956. 


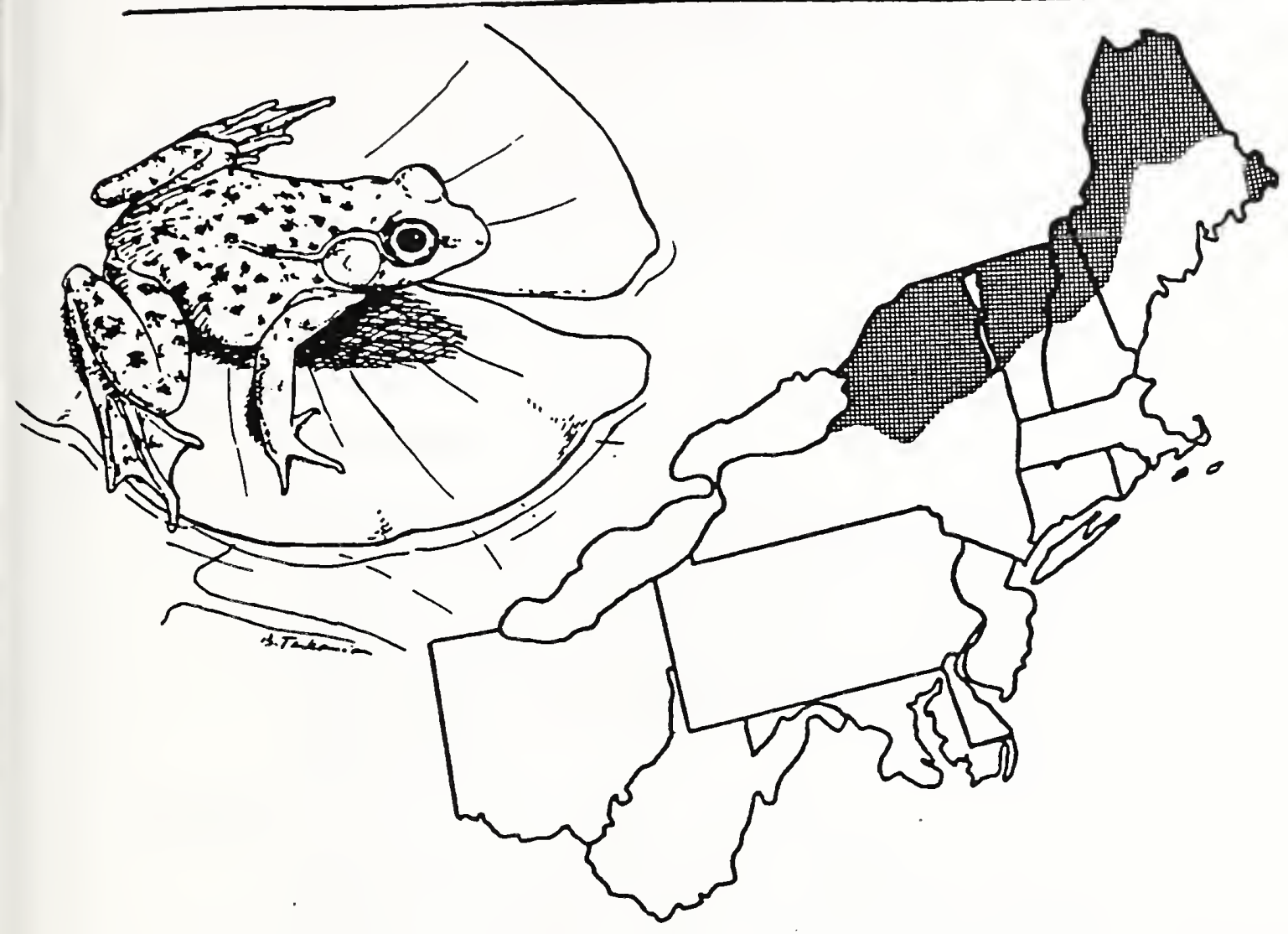

Range: Nova Scotia, n. New England and New York west to $n$. Wisconsin and Minnesota, north through Ontario to St. James Bay and to $n$. Quebec and Labrador.

Relative Abundance in the Northeast: Only in extreme northern areas, locally common to rare.

Habitat in the Northeast: At the edges of northern lakes and ponds, cold springs, inlets where cold streams enter ponds and stream edges. Prefers open water with abundant lily pads. Sometimes found in northern bogs.

Special Habitat Requirements: Breeds and hibernates only in permanent waters. Prefers lily pads in open water, for basking and foraging (M. Stewart, pers, commun.).

Age/Size at Sexual Maturity: Males 1 year after metamorphosis, females 1 to 2 years after matamorphosis (Hedeen 1972). 
Breeding Period and Egg Deposition: June to early August (Hedeen 1972), peak in July (Wright and Wright 1949:535).

No. Eggs/Mass: One individual laid 509 eggs (Hedeen 1972). Eggs laid in globular jelly-like masses attached to underwater vegetation such as spatterdock (Nuphar) then drop to bottom where they develop (M. Stewart, pers. commun.).

Time to Hatching: Unreported.

Tadpoles: For 1 to 2 years. Transform during summer months.

Home Range/Movement: Unreported.

Food Habits/Preferences: Adults feed from lily pads on animal matter, including adult insects and larvae, particularly aphids and chrysomelids (Kramek 1972, 1976), also minnows, millipedes, leeches, snails, spiders; plant material taken inadvertently. Most prey taken from the water surface--usually opportunistic feeders but can be selective (Kramek 1972). Diet is a reflection of prey species availability. Tadpoles feed primarily on algae (Hedeen 1970).

Comments: Very similar to Rana clamitans in appearance and habits. Adults produce a musky scent, especially when handled roughly (Conant 1975:342). Competition from green frogs and bullfrogs may be an important factor in habitat selection in the Northeast (M. Stewart, pers. commun.). In ponds treated with rotenone in the Adirondacks the anuran community of green, mink and bullfrogs probably requires 10 to 15 years to recover to pre-treatment levels (Stewart 1975).

Selected References: Logier 1952, Marshall and Buel1 1955, Hedeen 1977. 


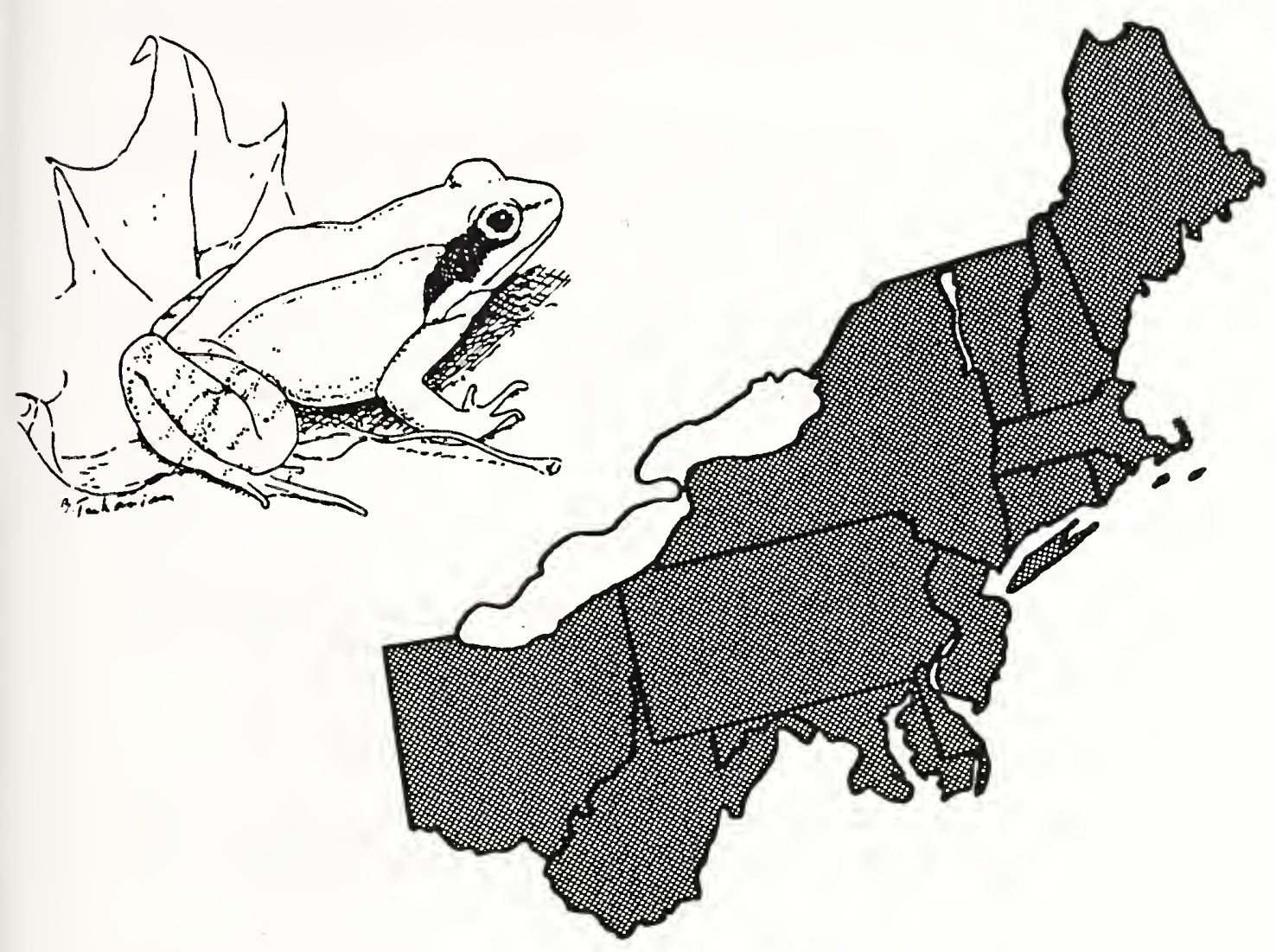

Range: Atlantic provinces and $n$. Quebec to Alaska (northern limit is along treeline) south into North Dakota, the Great Lakes States, to the Appalachians in Tennessee and extreme $n$. Georgia. Throughout the Northeast.

Relative Abundance in the Northeast: Common in suitable habitat.

Habitat in the Northeast: Terrestrial; in mesic woods, often far from water during the summer months as woodland ponds dry up; xeric woods with moist micro-habitats (M. Klemens, pers. commun.). Prefers wooded areas with small ponds for breeding (Heatwole 1961). Found in boreal conifer forests, swamps and upland hardwood forests to elevations of $1,158 \mathrm{~m}$ (Trapido and Clausen 1938). Found in bogs and trap rock slopes in Connecticut (M. Klemens, pers. commun.). Hibernates under moist forest floor debris or flooded meadows (M. Klemens, pers. commun.) from October to late March. Embryos and larvae showed limited tolerance to water with a high humic content in a Minnesota peat bog (Karns 1980).

Special Habitat Requirements: Prefers temporary woodland pools, back waters of slow moving streams. 


\section{.}


Age, Size at Sexual Maturity: Males at 2 years, females at 3 years (Bellis 1961).

Breeding Period and Egg Deposition: March to July at temperatures of about 50 F. (Smith 1956:113). Often breeds before ice is off the water (Martof 1970:86.2). Egg-laying usually completed within 4 to 6 days (Herreid and Kinney 1967).

No. Eggs/Mass: 2,000 to 3,000 eggs (Wright 1914:16), 1,019 average in Massachusetts (Possardt 1974). Eggs attached to submerged twigs or free at the bottom in globular masses.

Time to Hatching: 10 to 30 days (01iver 1955:236) temperature dependent.

Tadpoles: 6 to 15 weeks. (Minton 1972:132). May overwinter in n. Canada.

Home Range/Movement: Average home range size for 453 individuals in a Minnesota peat bog was $77.2 \mathrm{yd}^{2}\left(64.5 \mathrm{~m}^{2}\right)$, range 3.5 to $440.5 \mathrm{yd}^{2}$ $\left(2.9\right.$ to $\left.368.3 \mathrm{~m}^{2}\right)$. Distance between captures averaged $12.3 \mathrm{yd}$ $(16.2 \mathrm{~m})$ and ranged from 0 to $78 \mathrm{yd}(0$ to $71.3 \mathrm{~m})$ as reported by Bellis (1965).

Food Habits/Preferences: Insects; particularly beetles, flies and hymenopterans (Moore and Strickland 1955), also spiders, snails, slugs and annelids.

Comments: Breeds before all other ranids in the Northeast. Adults have been observed migrating across surface ice toward chorusing wood frogs (T. Andrews, pers. observ.). Brush piles, grassy hummocks and other terrestrial objects used as cover rather than utilizing aquatic escape (Marshall and Buell 1955).

Selected References: Wright and Wright 1949, Heatwole 1961, Martof 1970. 


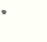


, . 
Breeding Period and Egg Deposition: March to May, congregates to breed (Wright and Wright 1949:482).

No. Eggs/Mass: 4,000 to 6,500 eggs laid in masses in shallow water, sometimes attached to twigs.

Time to Hatching: 13 to 20 days (Wright 1914:58).

Tadpoles: 9 to 12 weeks, transform July and August. Overwinter as tadpoles in Nova Scotia (Bleakney 1952).

Home Range/Movement: Daily travel within home range reported to be usually less than 5 to $10 \mathrm{~m}$ in wet pasture and marsh (Dole 1965). Average nightly movement during rainy periods was $36 \mathrm{~m}$ in Michigan (Dole 1968). There was occasional long-range movement, often exceeding $100 \mathrm{~m}$ during rainy nights (Dole 1965).

Food Habits/Preferences: Insects; particularly beetles, lepidopteran larvae, wasps, bugs, crickets, grasshoppers and ants; also takes sowbugs, spiders, small crayfish, snails and myriopods. Almost $99 \%$ of food items were insects and spiders (Drake 1914). Occasional records of having taken small birds and snakes. Food species taken correlates with peaks in insect prey abundance (Linzey 1967).

Comments: During dry summer days frogs may sit in "forms," smal1 clearings made in wet soil within their home range (Dole 1965). Most northeastern leopard frogs are probably introduced "exotics" released from laboratories and classrooms. Some believe the species is not native to New England (T. Tyning, pers. commun.).

Selected References: 'Logier 1952, Dole 1968. 


\section{.}




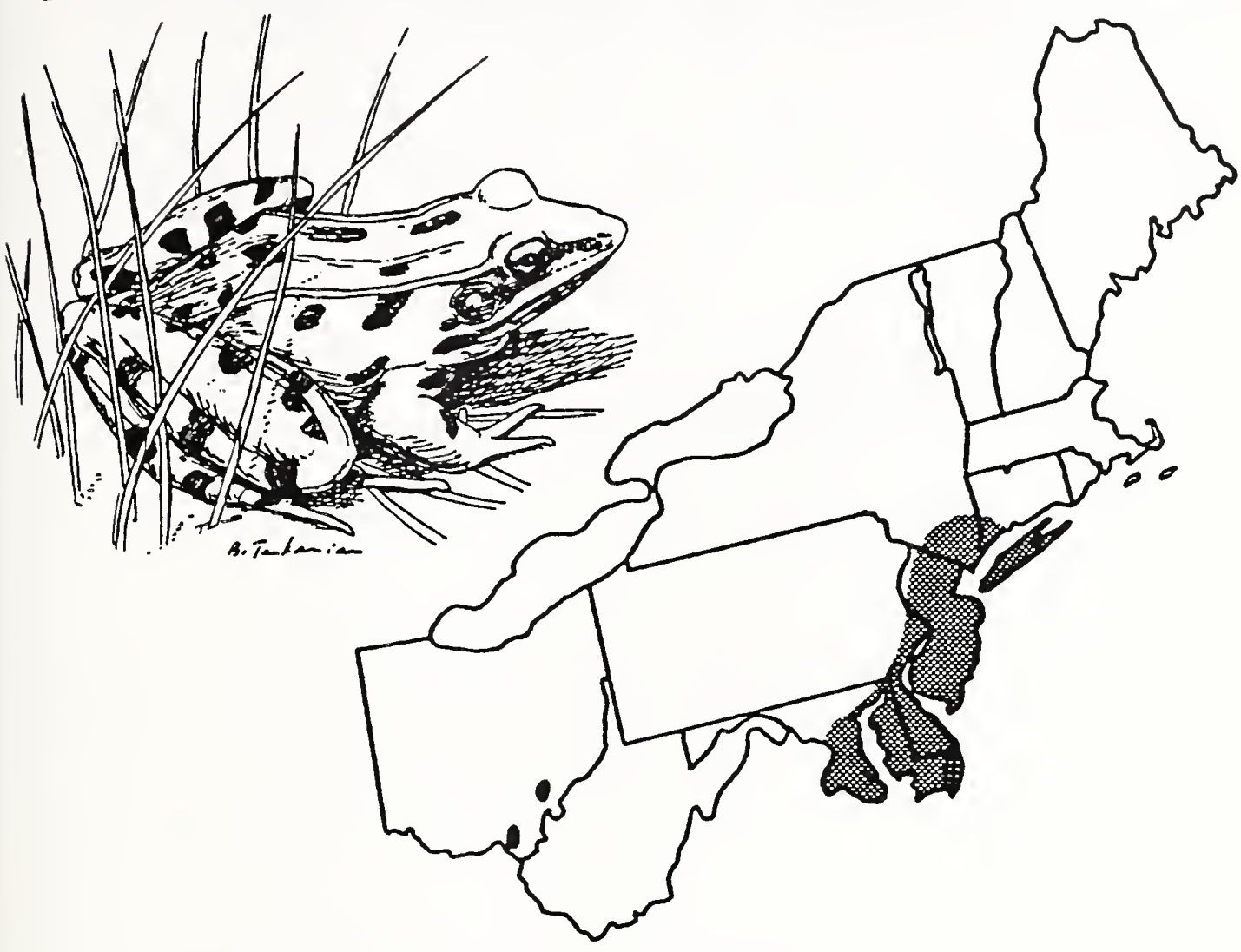

Range: Long Island and extreme s.e. New York and New Jersey south through the Coastal Plain to Florida, west through the Gulf States to e. Texas with $n$. range limits in Missouri, c. Illinois and Indiana. Absent from the higher elevations of the Appalachians.

Relative Abundance in the Northeast: Unreported.

Habitat in the Northeast: Ponds, meadows, "swamps, bogs, margins of streams and lakes, canaTs, flooded roads and ditches. Most frequently occurs occurs in open situations. Remains near water during spring and fall but may be found inland during the summer.

Special Habitat Requirements: Aquatic situations for breeding.

Age/Size at Sexual Maturity: Unreported.

Breeding Period and Egg Deposition: March to December, peak in April and August. 


$$
\text { . }
$$


No. Eggs/Mass: 3,000 to 5,000 eggs, attached to submerged twigs and stems in quiet shallow, often temporary water.

Time to Hatching: 7 to 12 days in Indiana (Minton 1972:126).

Tadpoles: 67 to 86 days (Wright and Wright 1949:494). May remain as tadpoles through the winter.

Home Range/Movements: Unreported.

Food Habits/Preferences: Beetles and other insects, caterpillars, spiders, snails, small frogs and sometimes other small vertebrates (Minton 1972:126-127).

Selected References: Wright and Wright 1949, Minton 1972. 
. 


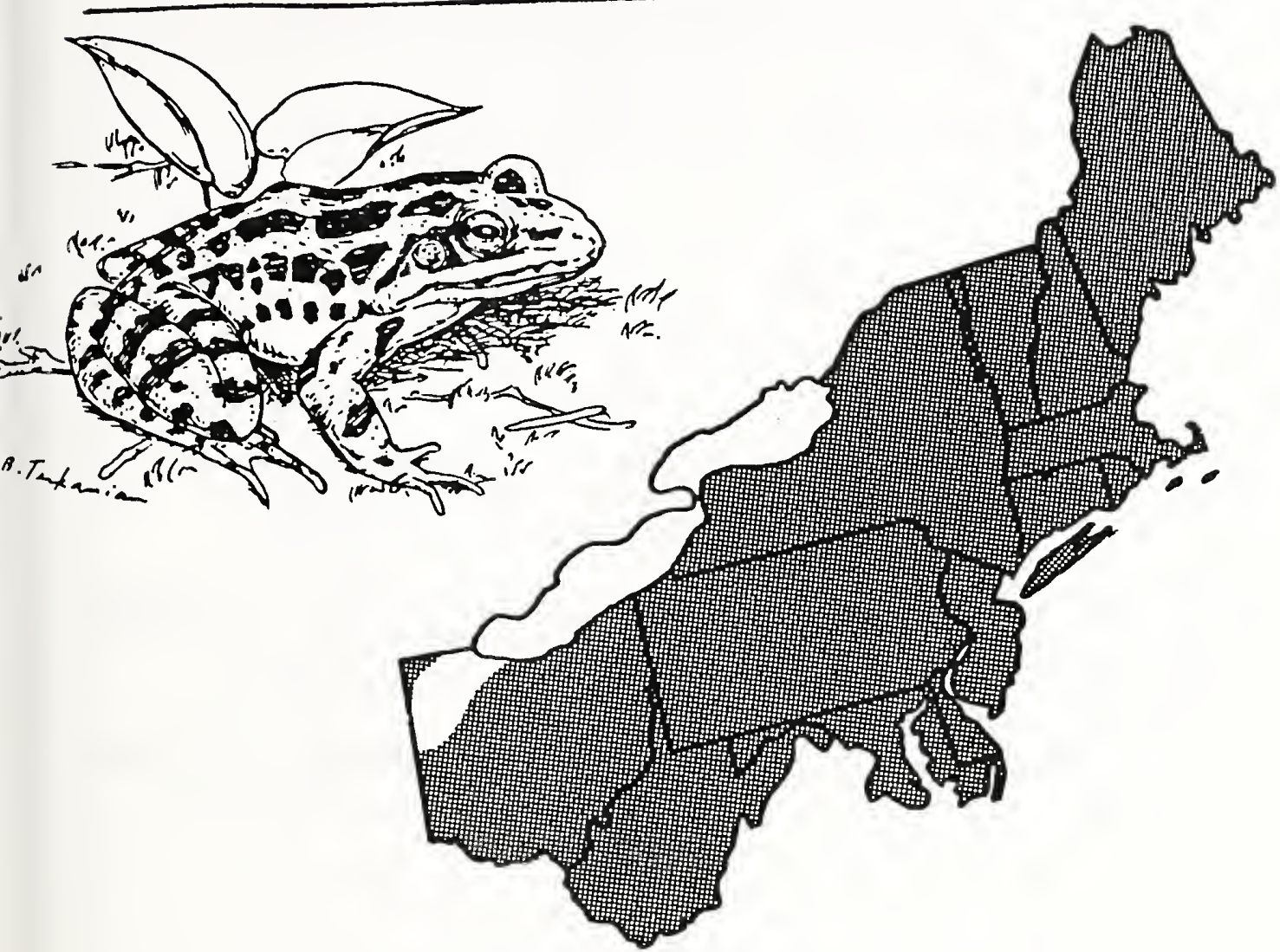

Range: Nova Scotia and the Gaspe Peninsula through s.e. Ontario to Wisconsin south to e. Texas and east to South Carolina. Absent from $c$. Illinois, n.w. Ohio and parts of the South.

Relative Abundance in the Northeast: Locally common.

Habitat in the Northeast: Colder waters of lakes, ponds, clear streams, springs, sphagnum bogs, limestone quarry pools. In Massachusetts, fairly ubiquitous along streams and shores of permanent ponds and lakes ( $T$. Andrews, pers. commun.). In summer found in pastures, fields or woodlands, often at a distance from water. Prefers water with thick vegetation at edges for cover. Hibernates in mud at bottom of ponds or in ravines under stones from October to March. Some individuals found wintering in caves in Indiana (Rand 1950).

Special Habitat Requirements: Shallow, clear water of bogs and woodland ponds for breeding.

Age/Size at Sexual Maturity: Unreported. 
Breeding Period and Egg Deposition: March to May.

No. Eggs/Mass: 2,000 to 3,000 eggs (Wright 1914:67). Eggs laid in firm globular masses attached to submerged plants and branches.

Time to Hatching: 11 to 21 days (Wright 1914:67).

Tadpoles: 80 to 100 days, some overwinter as tadpoles. Transform July to September.

Home Range/Movement: Unreported.

Food Habits/Preferences: In adults, 95\% of food items were terrestrial arthropods (Smith 1956:108). Snails, small crayfish, aquatic amphipods and isopods are also eaten.

Comments: Diurnal; may be crepuscular during hot weather. Sensitive to pollution and changes in water quality. Skin secretions may be toxic to other amphibians confined with pickerel frogs.

Selected References: Wright and Wright 1949, Smith 1956, Schaaf and Smith 1971. 

REPTILES 



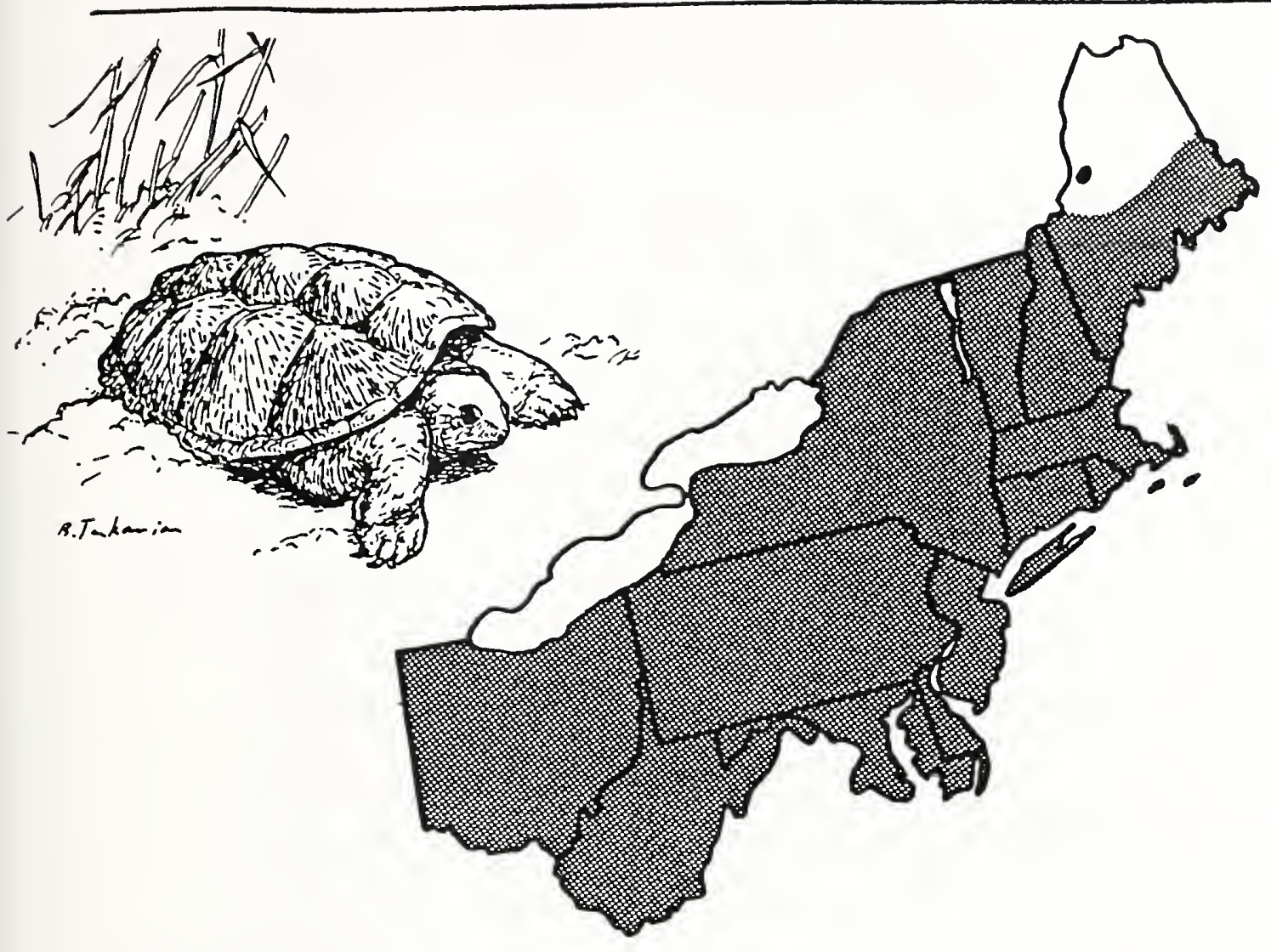

Range: Across the e. U.S. to the Rocky Mountains, s. Canada to the Gulf of Mexico and into Central America.

Relative Abundance in the Northeast: Common.

Habitat in the Northeast: Bottom dweller in any permanent and many semi-permanent bodies of fresh or brackish water; occasionally in temporary water. Marshes, swamps, bogs, pools, lakes, streams, rivers, frequently in areas with soft muddy banks or bottoms. Formerly thought to prefer permanent water. Almost entirely aquatic, but will travel overland. Hibernates from October to March or April in mud or debris at lake bottoms, banks, and muskrat holes, but has been seen walking on and under the ice (Carr 1952:64). Little known about winter activity.

Special Habitat Requirements: Aquatic habitat.

Age/Size at Sexual Maturity: Carapace length of 10 in $(25.4 \mathrm{~cm})$ as reported by Hammer (1969).

Breeding Period: Late April to November, sperm may remain viable in females for several years. 

Egg Deposition: Mid-June. Nests made in soil of banks or in muskrat houses. Also on lawns, driveways, fields, sometimes far from water.

Clutch Size: 11 to 83 eggs; females may lay two clutches per year in southern portions of range. Typically 20 to 30 eggs per clutch (Cahn 1937 cited in Conant 1938:128).

Incubation Period: 55 to 125 days (Hammer 1969), typically 80 to 91 days but dependent upon environmental conditions.

Eggs Hatch: Late August to early October, may overwinter in nest until spring in northern portions of range. Nests often destroyed by mammalian predators.

Home Range/Movement: Average distance traveled by 107 individuals was $0.69 \mathrm{mi}(1.1 \mathrm{~km})$, with most movement within the same marsh in South Dakota (Hammer 1969). In a New York marsh, movement of $100 \mathrm{~m}$ was the average for 85 individuals; home ranges 3 to 9 ha (Kivait 1980). Established range in Pennsylvania 4.5 ac (1.8 ha), reported by Ernst (1968b). Quite migratory. Females exhibit strong nesting site fidelity and will travel more than $0.5 \mathrm{~km}$ overland through forest and uneven terrain between water bodies in Ontario. Maximum distance of $16 \mathrm{~km}$ between home range and nesting site (Obbard and Brooks 1980).

Food Habits/Preferences: Omnivorous feeders; animal matter comprising $54 \%$ of prey items including fish (40\%), crayfish, aquatic invertebrates, reptiles, birds, mammals; plant material $37 \%$ (Alexander 1943). Primary fish species in diet included suckers, bullheads, sunfish, and perch in Connecticut (Alexander 1943). May occasionally take young waterfowl; not destructive to natural systems concerning fish or waterfowl. Scavenges for any food readily available.

Comments: High levels of persisting organochlorine contaminants found in the tissues of Hudson River specimens (Stone et al. 1980).

Selected References: Babcock 1919, Hammer 1969, Kivait 1980. 


Age/Size at Sexual Maturity: Stinkpots in the northern portion of the range mature more slowly than individuals in the southern regions. Males at 3 or 4 years, females at 2 to 7 years (Tinkle 1961), or perhaps at 9 to 11 years (Risely 1932).

Breeding Period: April to October, peak in April to May, September to October.

Egg Deposition: May to August, peak in June. Eggs laid in muck, rotted logs, stumps, sandy soil, grass, or on the ground on lake margins.

Clutch Size: 1 to 9 eggs (highest numbers in North), typically 3 to 6 . Incubation Period: 60 to 90 days (Barbour 1971:162), 35 to 40 days (Edgren 1960).

Eggs Hatch: September to October (in North). Gregarious nesting habits, of ten odorous.

Home Range/Movement: Overland movements probably seasonal or forced (Ernst and Barbour 1972:40). Average home ranges of 0.06 ac (0.02 ha) for males and 0.12 ac $(0.05$ ha) for females in Oklahoma. Overland movements ranged from 166 to $227 \mathrm{ft}(35.4$ to $69.2 \mathrm{~m}$ ) for males, and 113 to $146 \mathrm{ft}(34.4$ to $44.5 \mathrm{~m})$ for females (Mahmoud 1969). Exhibited homing behavior in Michigan-13 out of 28 released individuals traveled up to $700 \mathrm{ft}(213 \mathrm{~m})$ to initial capture points (Williams 1952).

Food Habits/Preferences: Principally carnivorous, feeds along the bottom for snails, clams, aquatic insects and their larvae, particularly dragonfly nymphs and caddisfly larvae (Lagler 1943), minnows, worms, tadpoles, and fish eggs (Babcock 1919:36). As scavengers, plants, algae, and carrion are also eaten. Carrion comprised $40 \%$ of the diet by volume for 73 individuals in Michigan (Lagler 1943).

Comments: Also called the musk turtle. Often basks well out of water on horizontal limbs of slanting trees along the waters' edge. Known to bask on overhanging branches and on logs and rocks. Highly aquatic; activity periods in morning and evening in Ok7ahoma (Mahmoud 1968). Nocturnal, best observed with a flashlight along lake/pond margins. Individuals frequently covered with algae growth.

Selected References: Mahmoud 1969, Ernst and Barbour 1972. 


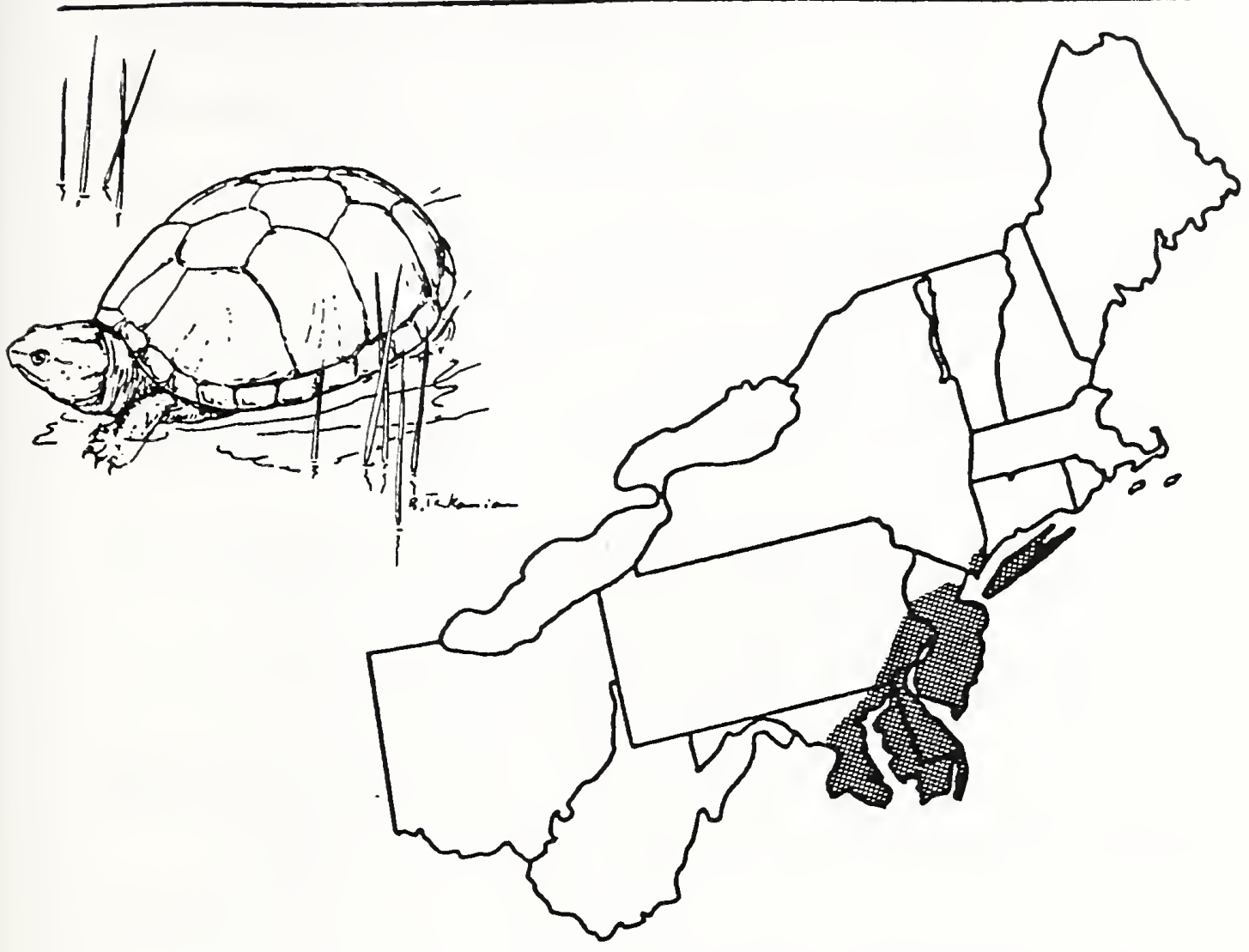

Range: Long Island and Staten Island along coast to Mississippi River across to n. Florida. Not found north of Harbor Hill recessional moraine, Wisconsin Glaciation (Craig et al. 1980).

Relative Abundance in the Northeast: Uncommon.

Habitat in the Northeast: Permanent or temporary, fresh or brackish shallow water with aquatic vegetation. Found in shallow lakes with overhanging vegetation, marshes, small ponds, ditches, wet fields and offshore islands. Semi-aquatic, not found in deep or moving water. Will burrow into mud and aestivate when habitat dries. Hibernates in burrows in mud and dead leaves in marsh or field edges, below frost line, from October or November to March or Apri1 (Ernst and Barbour 1972:51). Some found active in winter.

Special Habitat Requirements: Still, shallow water with mud bottom. Age/Size at Sexual Maturity: Females 5 to 8 years, males 4 to 7 years, Oklahoma (Mahmoud 1967). Plastron length of 75 to $80 \mathrm{~mm}$ for females in Arkansas (Iverson 1979). 

Breeding Period: Mid-March to May.

Egg Deposition: June, later in the South. Eggs laid in depressions dug in soil, piles of vegetable debris, or in rotted wood.

Clutch Size: 2 to 6 eggs (Nichols 1947), typically 3 eggs per clutch. Three clutches laid per year (Iverson 1979).

Incubation Period: Average of 76 days (Lynn and vonBrand 1945), 106 days, Arkansas (Iverson 1979).

Eggs Hatch: September in Maryland (McCauley 1945:145), may overwinter in the nest.

Home Range/Movement: Limited home range, 0.12 to 0.13 ac $(0.049$ to 0.052 ha) (Mahmoud 1969) in Oklahoma.* In South Carolina, average travel was $3.6 \mathrm{~m} /$ day with a cycle of short movements of less than $2 \mathrm{~m} /$ day, followed by burrowing (up to 2 weeks), then longer moves ( $10 \mathrm{~m} /$ day) until December when movement stopped (Bennet et a1. 1970).

Food Habits/Preferences: Forages in bottom mud. Omnivorous, eating insects, crustaceans, mollusks, amphibians, carrion and aquatic vegetation (Mahmoud 1968).

Selected References: Mahmoud 1969, Ernst and Barbour 1972, Iverson 1977.

*Subspecies K. s. hippocrepis. 



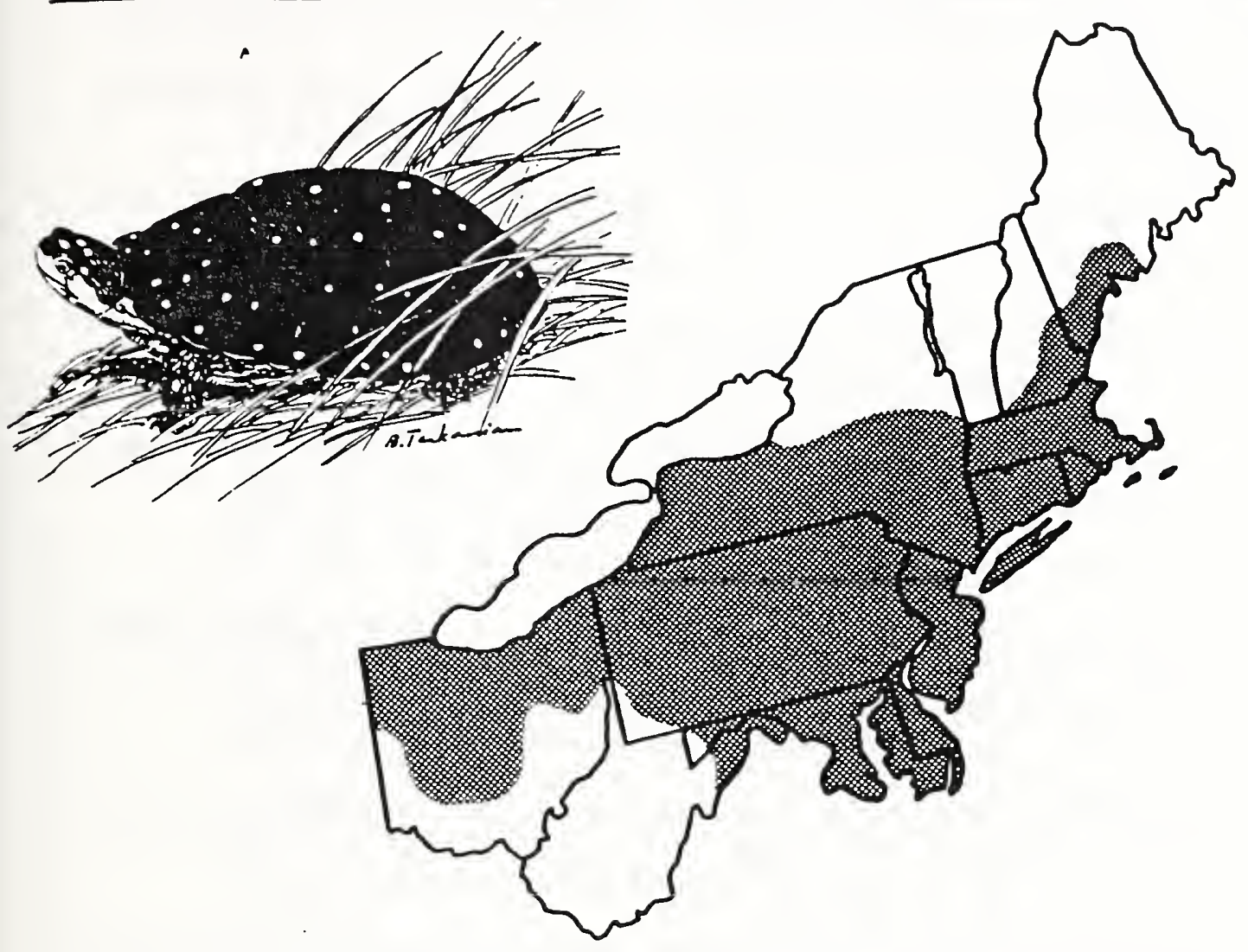

Range: Southern Maine to s. Quebec west to Lake Michigan, n. half of Ohio to e. portion of Virginia south to n. Florida.

Relative Abundance in the Northeast: Uncommon to rare.

Habitat in the Northeast: In unpolluted, small shallow bodies of water such as woodland streams, wet meadows, bog holes, small ponds, marshes, swamps, roadside ditches, and brackish tidal creeks.

Prefers areas with aquatic vegetation. Hides in mud and detritus at bottom. Wanders over land. Basks along waters' edge on brush piles in water (Graham, pers. commun.) and on logs or vegetation clumps. Often found in cranberry bogs. Hibernates in muddy bottoms during the coldest winter months. May aestivate during hottest periods of summer (T. Tyning, pers. commun.).

Special Habitat Requirements: Unpolluted shallow water.

Age/Size at Sexual Maturity: Males $>83.4 \mathrm{~mm}$ plastron length, females $>80.8 \mathrm{~mm}$ plastron length in Pennsylvania (Ernst and Barbour 1972:73). 


\section{Spotted Turtle}

Breeding Period: March to May, peak usually June.

Egg Deposition: June to July. Eggs usually laid in well-drained soil of marshy pastures, or in tussocks (M. Klemens, pers. commun.).

Clutch Size: 1 to 8 eggs (Adler 1961), average 3 to 5 .

Incubation Period: 70 to 83 days.

Eggs Hatch: Late August (Ernst and Barbour 1972:74) to September (Finneran 1948). Overwintering in nest may occur.

Home Range/Movement: Adults in a Pennsylvania marsh averaged 1.3 ac (0.5 ha) according to Ernst (1968b), moved less than $0.5 \mathrm{mi}$ $(0.8 \mathrm{~km})$ also reported by Ernst (1968a). Females migrate outside of home range to nest (Ernst 1970).

Food Habits/Preferences: Omnivorous, eating crustaceans, mollusks, spiders, earthworms, aquatic insects, and other invertebrates; occasionally takes frogs and tadpoles, small fish, carrion, and vegetable matter. Food taken only under water.

Comments: Over-collecting, coupled with draining and filling of swamps (and possibly pollution) is depleting the population. A strongly diurnal species (Graham and Hutchinson 1979).

Selected References: Ernst 1972a, Ernst and Barbour 1972, Stewart 1974. 
Breeding Period: Late April to early June.

Egg Deposition: June to July, often in tussocks or on top of sphagnum in open, sunny areas of bogs (Zappalorti et al. 1979).

Clutch Size: 2 to 5, typically 2 to 3 (Zappalorti et al. 1979).

Incubation Period: 7 to 8 weeks (Nemuras 1969).

Eggs Hatch: July to early September (Ernst and Barbour 1972:77-78). In northern locations hatchlings may overwinter in the nest.

Home Range/Movement: Average range was 1.28 ha for 19 individuals in Lancaster County, Pennsylvania (Ernst 1977). Ranging from 0.008 to $0.943 \mathrm{ha}$, with travel through wet runs (Barton 1957 cited in Ernst 1977:246). Average movement was $12 \mathrm{~m}$ between recaptures for a male; when displaced the same individual moved $0.4 \mathrm{~km}$ in 1 day returning to initial point of capture (Ernst and Barbour 1972:79).

Food Habits/Preferences: Omnivorous, eating berries (20\%), insects ( $80 \%$ ), (Surface 1908:158), also slugs, earthworms, crayfish, frogs, snakes, nestling birds, seeds of pondweeds and sedges, snails, carrion; availability determines food consumption (Barton and Price 1955). Forages on land and under water.

Comments: Formerly named Muhlenberg's turtle. May aestivate during dry summer months (Ernst and Barbour 1972:77). Seldom active during the hottest part of the day (Zappalorti and Farrell 1980). Overcollection of this species is a problem, and locality information should be reported with discretion to prevent exploitation. Formerly abundant; population decrease related to wetland drainage and fill.

Selected References: Barton and Price 1955, Ernst and Bury 1977, Bury 1979, Zappalorti et a1. 1979, Zappalorti and Farrel1 1980. 



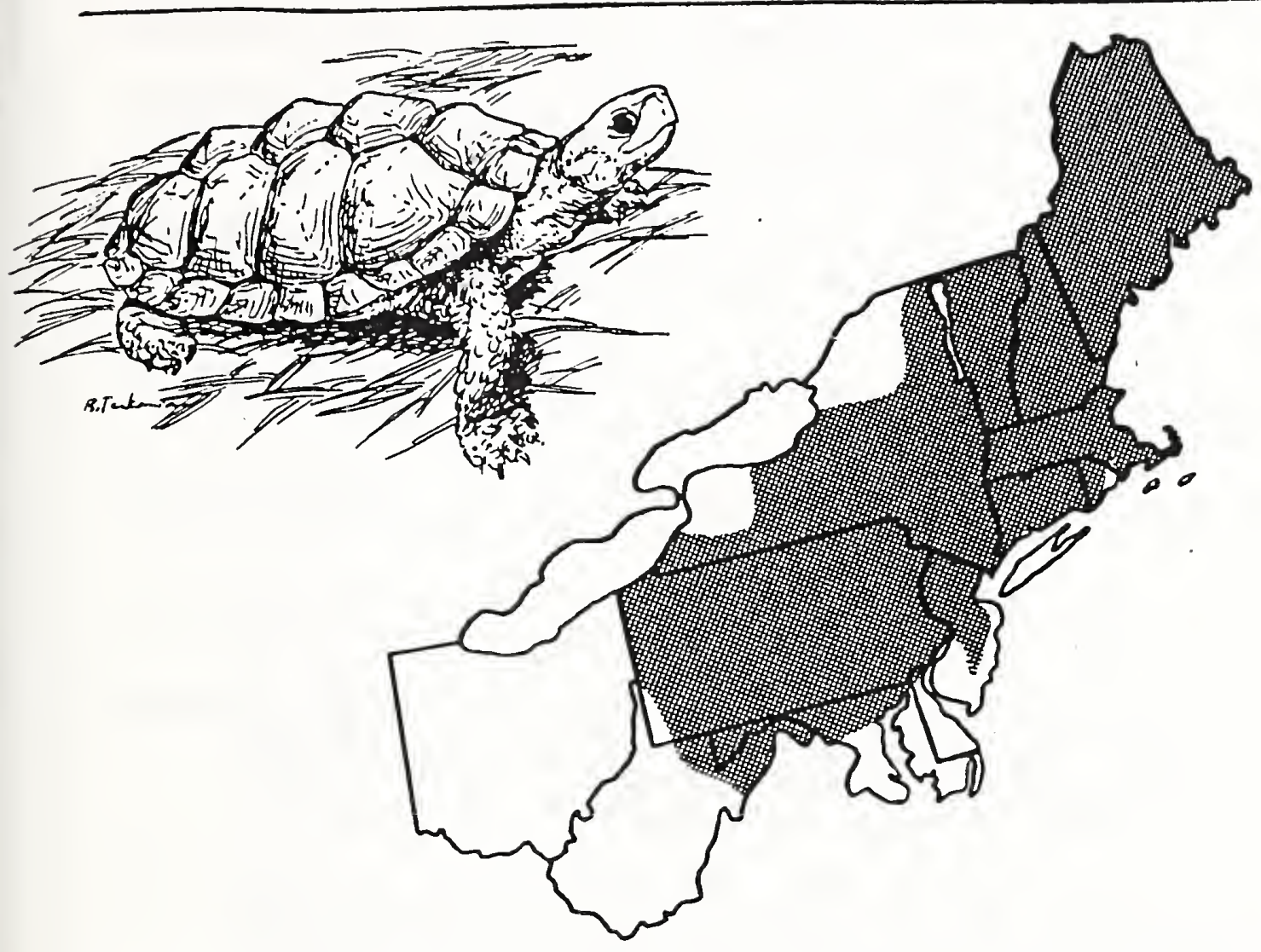

Range: Nova Scotia west through the Great Lakes region to e. Minnesota. In the East extending southward to $n$. Virginia.

Relative Abundance in the Northeast: Once common, population declining.

Habitat in the Northeast: Frequents slow moving meandering streams with sandy bottoms and overhanging alders (Graham, pers. commun.). Basks during morning hours along banks of streams. Disperses from water sources during summer months to fields, woods, roadsides. Restricted to hardwood forest areas in New Jersey (Farrell and Zappalorti 1979).

Returns in fall to streams to hibernate in muddy banks and bottoms through late March to April. Have been found hibernating in holes in stream banks (Graham, pers. commun.), in decaying vegetation of woods and trout streams with deep pools (M. KTemens, pers. commun.). Will also use abandoned muskrat burrows (Collins 1976 cited in Farrell and Zappalorti 1979:11). Some use same hibernaculum each year (Farrell and Zappalorti 1979).

Special Habitat Requirements: Wooded river banks. 
Age/Size at Sexual Maturity: Unreported.

Breeding Period: March, May, October (Ernst and Barbour 1972:82), when stream temperature reaches about $15 \mathrm{C}$ (Farrell and

Zappalorti 1979). Mating occurs in water.

Egg Deposition: May to June. Eggs laid in prepared depressions in open areas with sandy soils or gravel, not necessarily near water.

Clutch Size: 4 to 12 eggs (Carr 1952:122), average 8 to 9 (Farrell and Zappalorti 1979).

Incubation Period: 77 days (Allen 1955), 58 to 69 days in laboratory (Farrel1 and Zappalorti 1980).

Eggs. Hatch: August to October. Hatchlings may overwinter in the nest in northern parts of range.

Home Range/Movement: One male moved an average of $90 \mathrm{~m}$ for 3 recaptures, one female was found $15 \mathrm{~m}$ from initial capture point (Ernst and Barbour 1972:83). Exhibited fidelity to a particular stream or brook in New Jersey (Farrell and Zappalorti 1979).

Food Habits/Preferences: Omnivorous, eating young vegetation, grass, moss, mushrooms, berries, insects and their larvae, worms, slugs, snails (Surface 1908:161-162); also carrion, tadpoles, frogs, and fish. Feeds in water or on land.

Corments: Formerly thought to be one of the most terrestrial turtles, now found equally in water or on land. Lives in large groups or colonies (Farrell and Zappalorti 1979). Diurna 1. Development of wooded river banks and widespread commercial collection are factors contributing to population decline. Not tolerant of pollution. Young not often encountered.

Selected References: Ernst 1972b, Farrell and Zappalorti 1979. 


Age/Size at Sexual Maturity: 4 to 5 years (Ernst and Barbour 1972:43), 5 to 10 years (Minton 1972:165).

Breeding Period: After emerging from hibernation in April, sometimes continuing to fall. Females may lay viable eggs for up to 4 years after mating (Ewing 1943).

Egg Deposition: June to July in the Northeast. Females often seen crossing roads in Massachusetts and New Jersey during nesting season (Graham, pers. commun.).

Clutch Size: 3 to 8 eggs, average 4 to 5 .

Incubation Period: 87 to 89 days (Allard 1935 cited in Carr 1952:146).

Eggs Hatch: August to September, may overwinter in nest.

Home Range/Movement: From 150 to $750 \mathrm{ft}(45.7$ to $228.4 \mathrm{~m})$; 12 individuals averaged movement of $390 \mathrm{ft}(118.8 \mathrm{~m})$ on Long Island (Breder 1927). For 62 individuals in mixed woodlands and open habitat on Long Island average range was less than $750 \mathrm{ft}(228.4 \mathrm{~m})$ as reported by Nichols (1939). Stickel (1950) reported average diameter was $350 \mathrm{ft}(106.6 \mathrm{~m})$ in Maryland. One individual was found within $0.25 \mathrm{mi}(0.4 \mathrm{~km})$ from point of release 60 years previous $7 \mathrm{y}$ (Allen 1968 cited in Babcock 1919:412). Maintains same home range for many years, occasionally leaves normal home range for random wandering or egg laying (Stickel 1950). Homing instinct displayed by 45 out of 60 turtles (Nichols 1939).

Food Habits/Preferences: Younger individuals chiefly carnivorous, older individuals more herbivorous. Food items include animals such as earthworms, slugs, snails, insects and their larvae, particularly grasshoppers, moths, and beetles; crayfish, frogs, toads, snakes, and carrion; vegetable matter such as leaves, grass, bugs, berries, fruits, and fungi.

Comments: Terrestrial and diurnal. Digs into leaf litter towards end of day. Bisection of habitat by roads can reduce or destroy populations. The reversion of much agricultural land to woodland may be a beneficial change to populations (Klemens, pers. commun.). Estimated age at full growth is 20 years. May live 60 to 80 years (Nichols 1939). Some individuals may live over 100 years (Graham and Hutchinson 1969).

Selected References: Stickel 1950, Carr 1952, Ernst and Barbour 1972. 



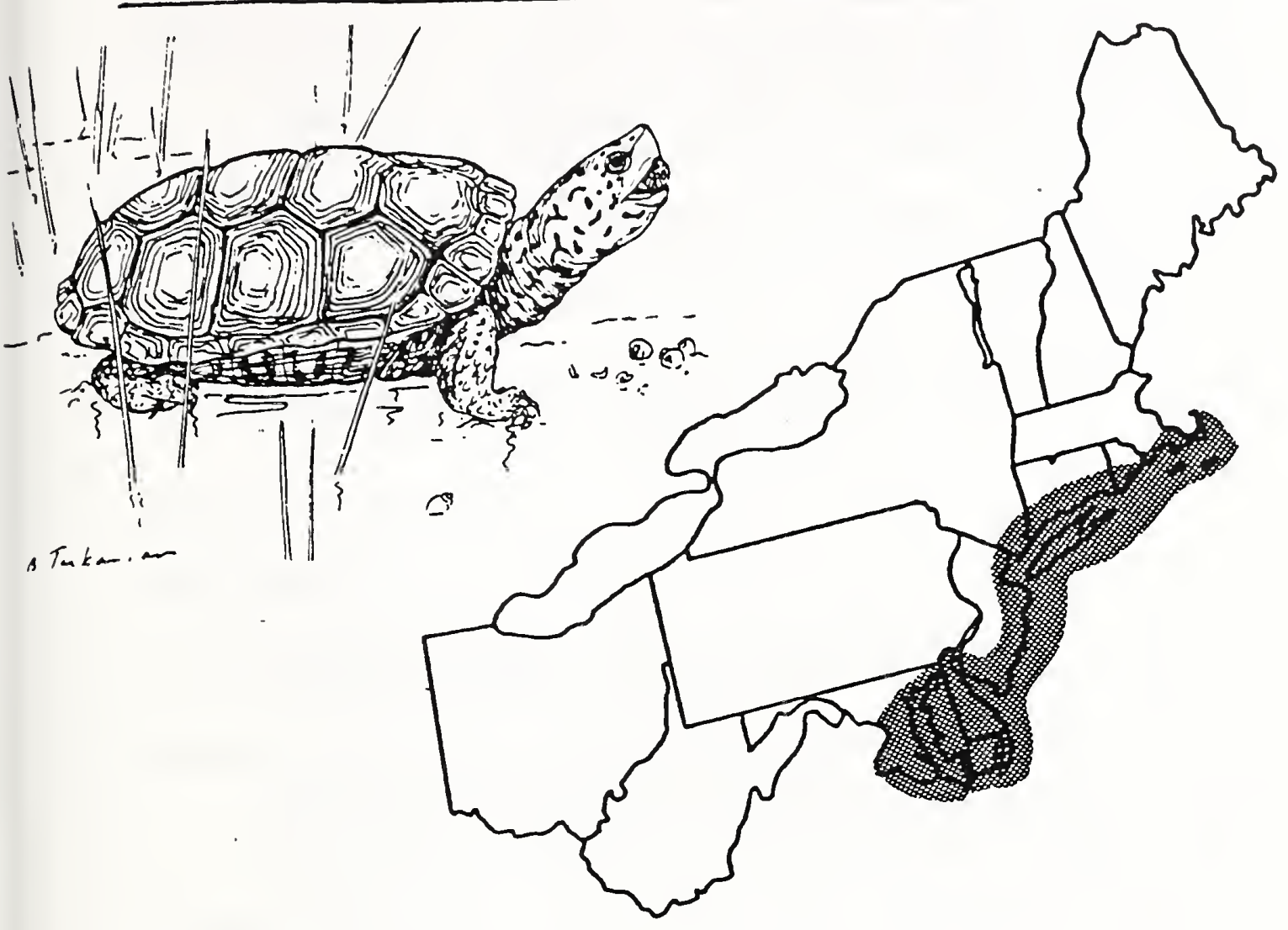

Range: Brackish waters of the Atlantic coast from Cape Cod to Cape Hatteras.

Relative Abundance in the Northeast: Uncommon to rare in Massachusetts and Rhode Island, extremely abundant in New Jersey and Maryland.

Habitat in the Northeast: Prefers salt marshes, brackish waters of coastal rivers, estuarine areas, tidal creeks. Nests built in sandy hummocks or dunes above high tide mark where the soil is anchored by grasses. Nests extensively on dike roads throughout the South Jersey coastal region (Graham, pers. observ.). Hibernates in muddy bottoms of streams or ponds. May emerge during warm spells. Basks on mud flats or island hummocks.

Special Habitat Requirements: Coastal rivers, salt marshes. Age/Size at Sexual Maturity: Perhaps 7 years (Carr 1952:173). 

Breeding Period: Soon after hibernating ends (Hay 1904). Early to mid-May in Jama ica Bay, Queens County, New York (R. Cooks, pers. commun.). Females may retain live spermatozoa for up to 4 years without subsequent matings (01iver 1955:213).

Egg Deposition: May to June (Ernst and Barbour 1972:106).

Clutch Size: 5 to 12 eggs, average 8. 1 to 5 clutches laid per individual.

Incubation Period: 42 to 90 days, temperature-dependent (Carr 1952:172). May overwinter in the nest.

Eggs Hatch: September.

Home Range Size: Unreported.

Food Habits/Preferences: Fish, crustaceans, soft mollusks, insects, succulent growth of marsh plants. Scavenger, forages while floating.

Comments: The terrapin was such a valuable food source that early in the 20th Century the U.S. Bureau of Fisheries established an artificial propagation program in North Carolina. This species has greatly recovered since the 1920s (M. Klemens, pers. commun.).

Selected References: Babcock 1919, Carr 1952, Ernst and Barbour 1972. 



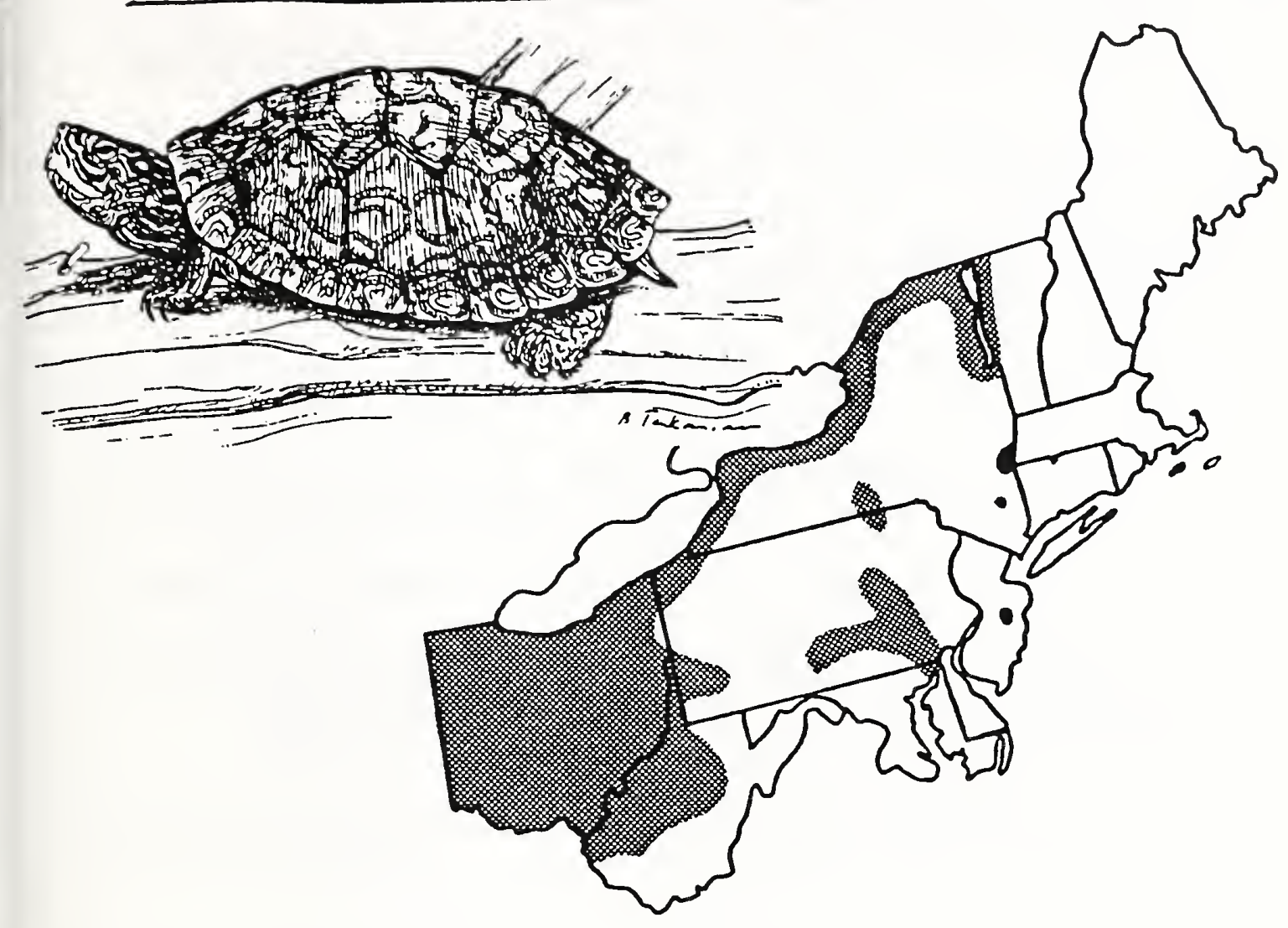

Range: Lake George, New York to the Great Lakes west to the Mississippi drainage to e. Minnesota, south to Louisiana and n.w. Georgia. Along Susquehanna drainage. Introduced to Delaware River. Nests as far south as Poughkeepsie, Duchess County, New York.

Relative Abundance in the Northeast: Uncommon and of limited distribution.

Habitat in the Northeast: Aquatic, inhabiting rivers and lakes. Prefers large bodies of water with soft bottoms and aquatic vegetation. Hibernates in mud of shallow water from late fall to early spring. May be active on or under ice. Gregariously basks on logs or rocks or along beaches and grassy shores. In Michigan found in riffles of pebble bottom streams that have interspersed, deeper, muddier pools (M. Klemens, pers. commun.). Move from shallow bays to nesting areas and reenter bays to overwinter in Quebec (Gordon 1980).

Special Habitat Requirements: Water bodies with muddy or soft bottom substrate. 

Age/Size at Sexual Maturity: Females at 7.5 in (190.5 mm) and larger (Newman 1906 cited in Pope 1939:169).

Breeding Period: April and autumn (Ernst and Barbour 1972:110).

Egg Deposition: May to July, peak mid-June. Nesting season begins in mid-June in Quebec and averages 2 weeks in duration (Gordon 1980). Nests made in soft sand or soil away from beaches.

Clutch Size: 10 to 16 eggs (Cahn 1937), typically 12 to 14 eggs. More than one clutch may be laid.

Eggs Hatch: Late August to early September (Carr 1952:199), some may overwinter in the nest.

Home Range/Movement: Unreported.

Food Habits/Preferences: Aquatic feeders--snails and clams are the major components of the diet; other small mollusks, crayfish, vegetable matter, fish, insects, and carrion are eaten (Carr 1952:199).

Selected References: Newman 1906, Evermann and Clarke 1916. 


Egg Deposition: April to mid-July. Females may be capable of reproducing for 40 to 50 years. Average longevity may be 50 to 75 years (Cagle 1950). Female excavates nest hole in earth, deposits eggs and seals hole with mud and debris. May move a mile $(1.6 \mathrm{~km})$ from water to find suitable nest site.

Clutch Size: 2 to 22, typically 5 to 10. 1 to 3 clutches per season. Incubation Period: 68 to 70 days (incubated in laboratory, Cagle 1950*).

Eggs Hatch: July 1 to mid-September (I1linois and Louisiana).

Home Range/Movement: Most sliders $(n=1,006)$ inhabiting a drainage ditch in Mississippi River floodplain remained within one-half mile $(0.8 \mathrm{~km})$ of release site (Cagle 1944:24).

Food Habits/Preferences: Omnivorous, taking tadpoles, crayfish, mollusks, large larvae of aquatic insects, small fish (Cahn 1937).

Comments: Possibly feral in Maryland (Cooper 1959). Active from late April until October in Illinois. Highly aquatic, avoids land except when laying eggs. Aestivates in mud when temperatures exceed 31 C (Cagle 1950:48).

Selected References: Cahn 1937, Cagle 1950, Cooper 1959, Webb 1961.

*Pseuderys scripta troastii 



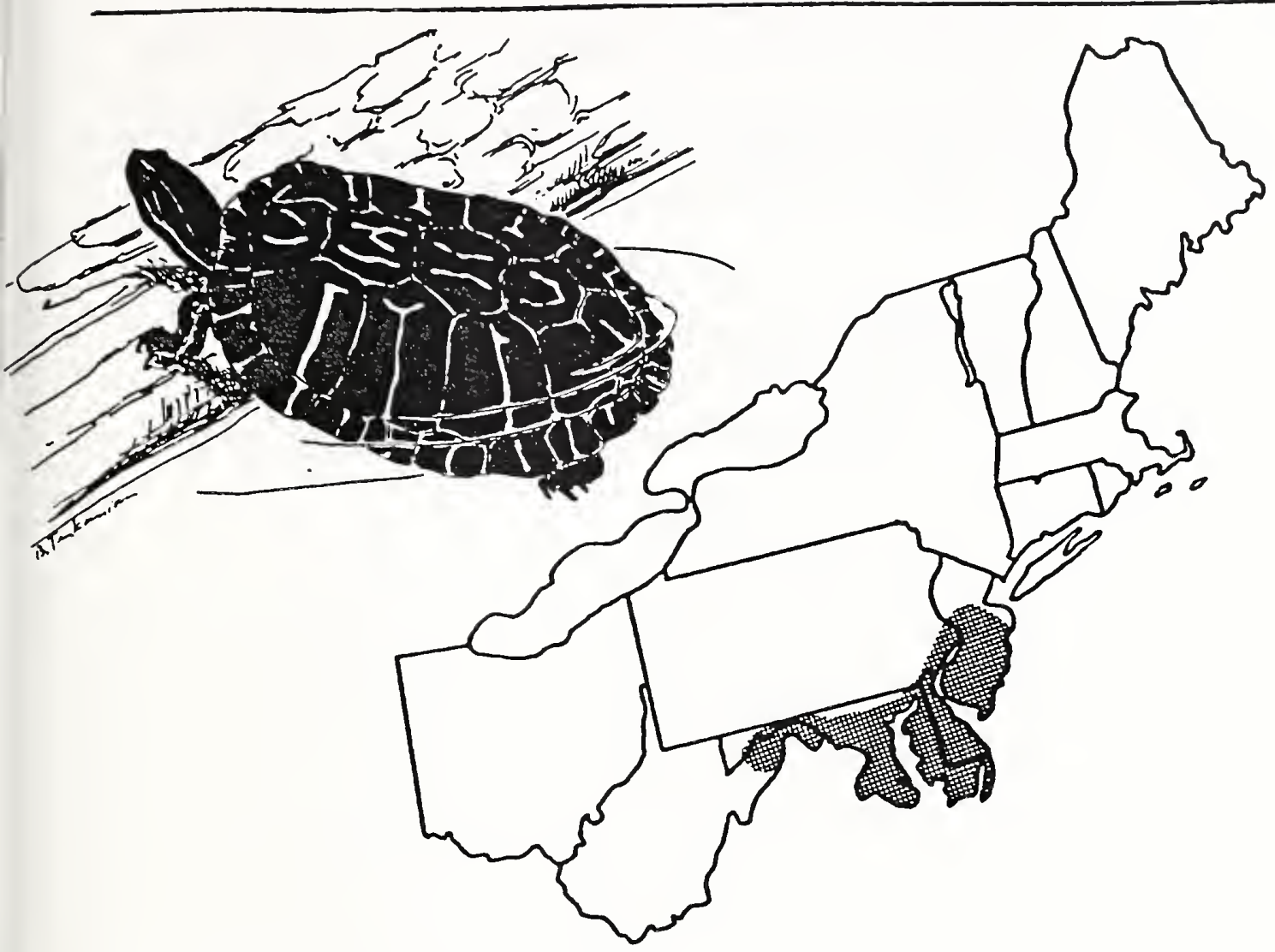

Range: Southern New Jersey throughout Maryland and inland to e. West Virginia, along the coast to Cape Hatteras.

Relative Abundance in the Northeast: Uncommon.

Habitat in the Northeast: Variable, including ponds, streams, lakes, salt marshes, rocky or muddy bottoms. Basks on shores or on rocks or logs. Hibernates in mud of ponds during winter months.

Special Habitat Requirements: Prefers larger bodies of fresh water.

Age at Sexual Maturity: Unreported.

Breeding Period: Presumed to be spring and fall.

Egg Deposition: June to early July. Eggs laid in fields bordering ponds or streams, along pond shores, near cranberry bogs in New Jersey

(Graham 1980). 

Clutch Size: 10 to 35 eggs (Martof et al. 1980:153).

Eggs Hatch: Early September in captivity (Carr 1952:272). May

overwinter in the nest. Emerge in late summer or the next

spring in the southern portion of range (Martof et al. 1980:153).

Home Range/Movement: Unreported.

Food Habits/Preferences: Omnivorous: aquatic vegetation, snails, tadpoles, crayfish, and fish are food items.

Selected References: Ernst and Barbour 1972. 



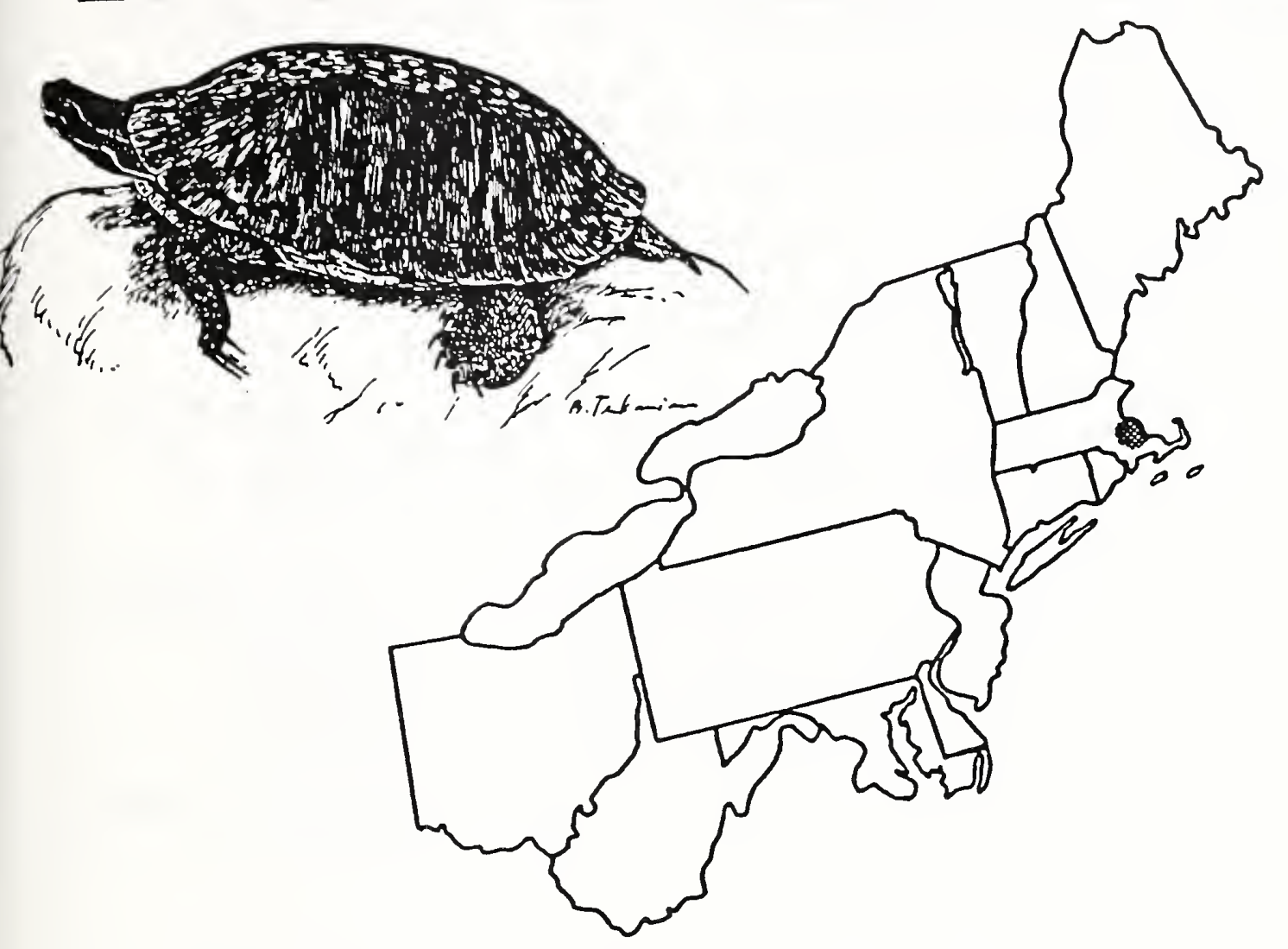

Range: Plymouth County, Massachusetts.

Relative Abundance in the Northeast: Endangered (Federal List).

Habitat in the Northeast: Ponds of different sizes in Plymouth County. Frequents shallow coves (Graham 1971a).

Special Habitat Requirements: Muddy-bottomed shallows with abundant aquatic vegetation, especially milfoil (Myriophyzzom) and bladderwort (Utricularia) (Graham 1980).

Age/Size at Sexual Maturity: Probably not reached during first 9 years (Graham 1971a). Average life span estimated at 40 to 55 years (Graham 1980).

Breeding Period: Probably early spring and fall (Graham, pers. commun.).

Egg Deposition: Mid-June to early July. 

Clutch Size: Range 12 to 17 eggs (Graham, unpubl. ms.).

Eggs Hatch: Probably September, fall (Graham, pers. commun.), July if they overwinter. Average hatching time of 75 days for 17 eggs laid in a laboratory (Graham 1971a).

Home Range/Movement: Unknown but wanders on land especially during fall and late spring. Found 0.5 to $2.0 \mathrm{mi}(0.8$ to $3.2 \mathrm{~km})$ from water on occasion. Significance of wandering unknown (Graham, unpubl. ms.).

Food Habits/Preferences: Primarily herbivorous, feeding mainly on milfoil, also feeds on bladderwort (Graham 1980) and arrowhead (Sagittaria) (Graham 1971a). Dietary shift to crayfish in fourth season (Graham 1971a).

Comments: Basks during early morning hours on elevated sites or in water by floating or resting on weed mats (Graham 1980). Discovered in Plymouth, Massachusetts by F. A. Lucas in 1869, first account in Copeia No. 38, 1916. Population estimate of about 100 in Plymouth County (Laze11 1976:155).

Selected References: Graham 1971a, 1971b, 1980; Laze11 1976. 



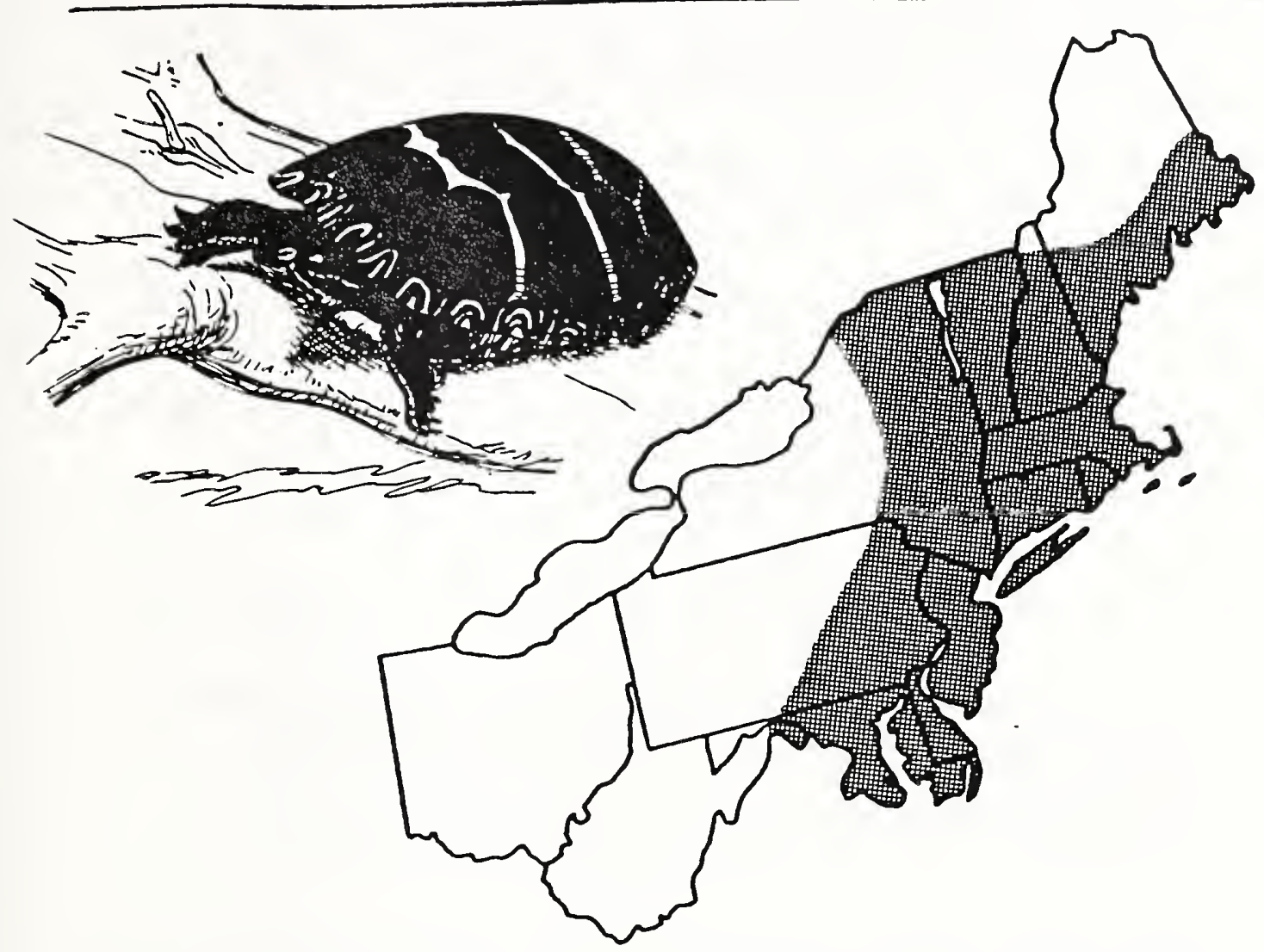

Range: Nova Scotia to n.e. New York, south to Cape Hatteras and inland to e. Alabama. In the Northeast merges with range of the Midland painted turtle.

Relative Abundance in the Northeast: Common, often abundant.

Habitat in the Northeast: Quiet, shallow ponds, marshes, woodland pools, rivers, lake shores, wet meadows, bogs, slow moving streams.

Sometimes in brackish tidal waters, salt marshes (Pope 1939:183).

Stagnant and polluted waters are sometimes inhabited (Smith 1956:

$150)$. When in water usually remains in submerged vegetation.

Basks on small hummocks, logs, rocks, sometimes congregating in

large groups. Hibernates by burrowing into mud or decayed vegetation of pond bottoms.

Special Habitat Requirements: Aquatic habitat.

Age/Size at Sexual Maturity: Correlated with size, in Michigan study males exceeded $81 \mathrm{~mm}$ plastron length, females ranged from 110 to $120 \mathrm{~mm}$ (Gibbons 1968a). 

Breeding Period: March to mid-June and fall (Gibbons 1968a). Peak in Aprit in Connecticut (Carr 1952:218).

Egg Deposition: May to July. Nest sites within a few yards of water (Cahn 1937 cited in Smith 1961:140), or up to one-half mile away (T. Tyning, pers. commun.).

Clutch Size: 2 to 11 , females may lay 2 clutches,(Gibbons 1968a), typically 5 to 6 .

Incubation Period: 72 to 80 days (Ernst and Barbour 1972:143). 63 days (Lynn and vonBrand 1945). Hatchings from late clutches may overwinter in the nest. Nests are often destroyed by raccoons and skunks.

Eggs Hatch: Late August to early September, in Connecticut (Finneran 1948).

Home Range/Movement: Displays short-distance homing ability; fewer than $15 \%$ moved more than $100 \mathrm{~m}$ in a marsh in Michigan (Gibbons 1968a). Average distance traveled was $112 \mathrm{~m}$ in a shallow bay of a Wiscons in lake; $70 \%$ of the turtles did not travel. Individuals may rema in in the same locality for years if conditions are favorable (Pearse 1923).

Food Habits/Preferences: Aquatic insects, snails, small fish, tadpoles, mussels, carrion, and aquatic plants taken by foraging along the bottom. Diet usually about $50 \%$ vegetation.

Comments: Diurnal. Emerges from hibernation in late March or early April in Massachusetts (Graham 1971a).

Chrysemys $p$. picta and Chrysemys picta marginata intergrade in the Northeast.

Selected References: Carr 1952, Gibbons 1968a, Ernst 1971, Ernst and Barbour 1972. 


Egg Deposition: June to July. Eggs often laid in high banks.

Clutch Size: 3 to 10 eggs, average 5 to 8 .

Eggs Hatch: Hatchlings emerge in September or the next spring (Smith 1961:140).

Home Range/Movement: Average summer movement within a pond about $90 \mathrm{~m}$. Movements have been divided into three types: initial emigration in the spring of 63 to $144 \mathrm{~m}$ from hibernation ponds to other ponds, preferably with vegetation mats; late summer movements of 86 to 91 $\mathrm{m}$, back to hibernation ponds; and late autumn movements of 88 to $130 \mathrm{~m}$ to deep water areas in Michigan (Sexton 1959). 60\% of individuals studies in a Michigan lake exhibited homing behavior (Williams 1952).

Food Habits/Preferences: Aquatic vascular plants, seeds, algae and invertebrates including crustaceans, mollusks, insects and their larvae, and worms. Also takes carrion, fish, and frogs. Aquatic plants comprised more than $60 \%$ of the diet and insects about 20\% in Michigan (Lagler 1943).

Comments: In New England there are no Midland turtle populations. Individuals are part of an intergrade swarm. Information provided in this account is based on references for Chrysemys picta marginata where intergrades do not occur. In New England, Chrysemys picta marginata and Chrysemys $p$. picta life history and habitat information are the same (M. Klemens, pers. commun.). Diurnal.

Selected References: Carr 1952, Sexton 1959, Smith 1961. 



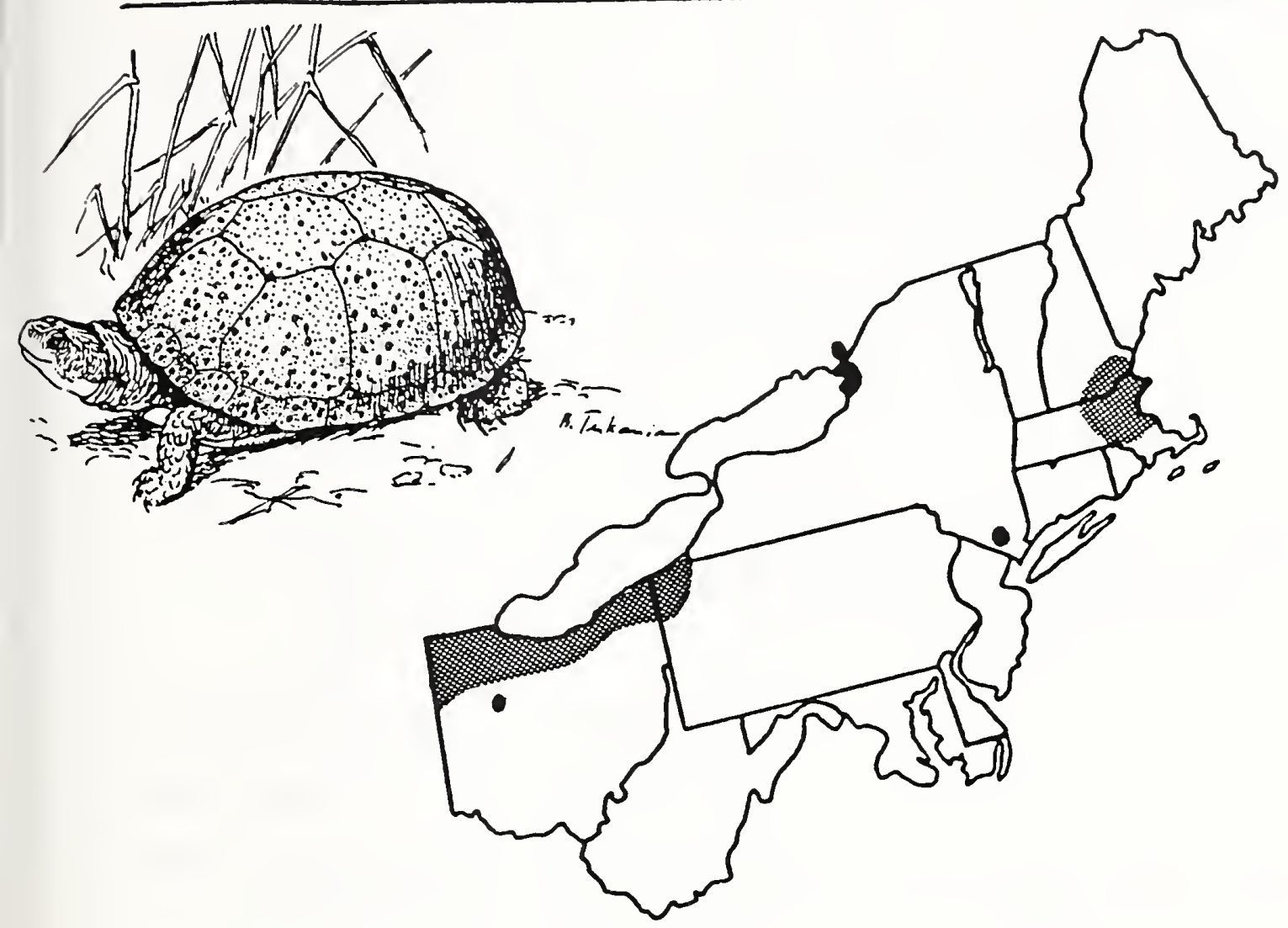

Range: In New England scattered colonies in New York, New Hampshire, and e. Massachusetts. Southern Quebec across the Lake States to c. Minnesota, south to Iowa and c. Illinois. Spotted occurrence from Nova Scotia to Ohio.

Relative Abundance in the Northeast: Populations localized and distribution spotty throughout its range (McCoy 1973:136.1). Generally scarce to rare, locally abundant in Massachusetts (Lazel1 1972). An endangered species in Canada.

Habitat in the Northeast: Shallow waters preferred; marshes, bogs, ditches, ponds, swamps, also in protected coves and inlets of large lakes with abundant aquatic vegetation. In Michigan found in rivers (M. Klemens, pers. commun.). May wander overland. Basks on logs, stumps, banks. Active in winter or hibernates in mud or debris.

Special Habitat Requirements: Shallow waters. 

Age/Size at Sexual Maturity: During 12th year for males with a plastron length of 181 to $190 \mathrm{~mm}$, Massachusetts (Graham and Doyle 1977); males 131 to $190 \mathrm{~mm}$ in Michigan (Gibbons 1968b). Size differences between these two populations probably due to differences in food quality and availability (Graham and Doyle 1977).

Breeding Period: Early spring through October, most often from March to May (Ernst and Barbour 1972:181). Peak in late April (Graham and Depain, unpubr.).

Egg Deposition: June to July. Nests made in sandy soils.

Clutch Size: 6 to 11 eggs (Carr 1952:136), typically 8 to 9 eggs, clutches of 9,13 , and 16 eggs for Massachusetts females (Graham and Depain, unpubl.). Clutch of 17 for a July nesting female (Graham and Doyle 1979). Two clutches may be laid each season.

Incubation Period: Unreported.

Eggs Hatch: Autumn or next spring.

Home Range/Movement: Less than $100 \mathrm{~m}$ for 4 individuals in a marsh in S.w. Michigan (Gibbons 1968b).

Food Habits/Preferences: Crustaceans, insects, mollusks, fish, carrion, aquatic plants, succulent shoots and berries. Crustaceans and crayfish comprise about $56 \%$ of diet, insects over $25 \%$, and other invertebrates and vegetable matter 25\% (Lagler 1943).

Comments: Primarily diurnal.

Selected References: Gibbons 1968b, McCoy 1973; Graham and Doyle 1977, 1979 . 



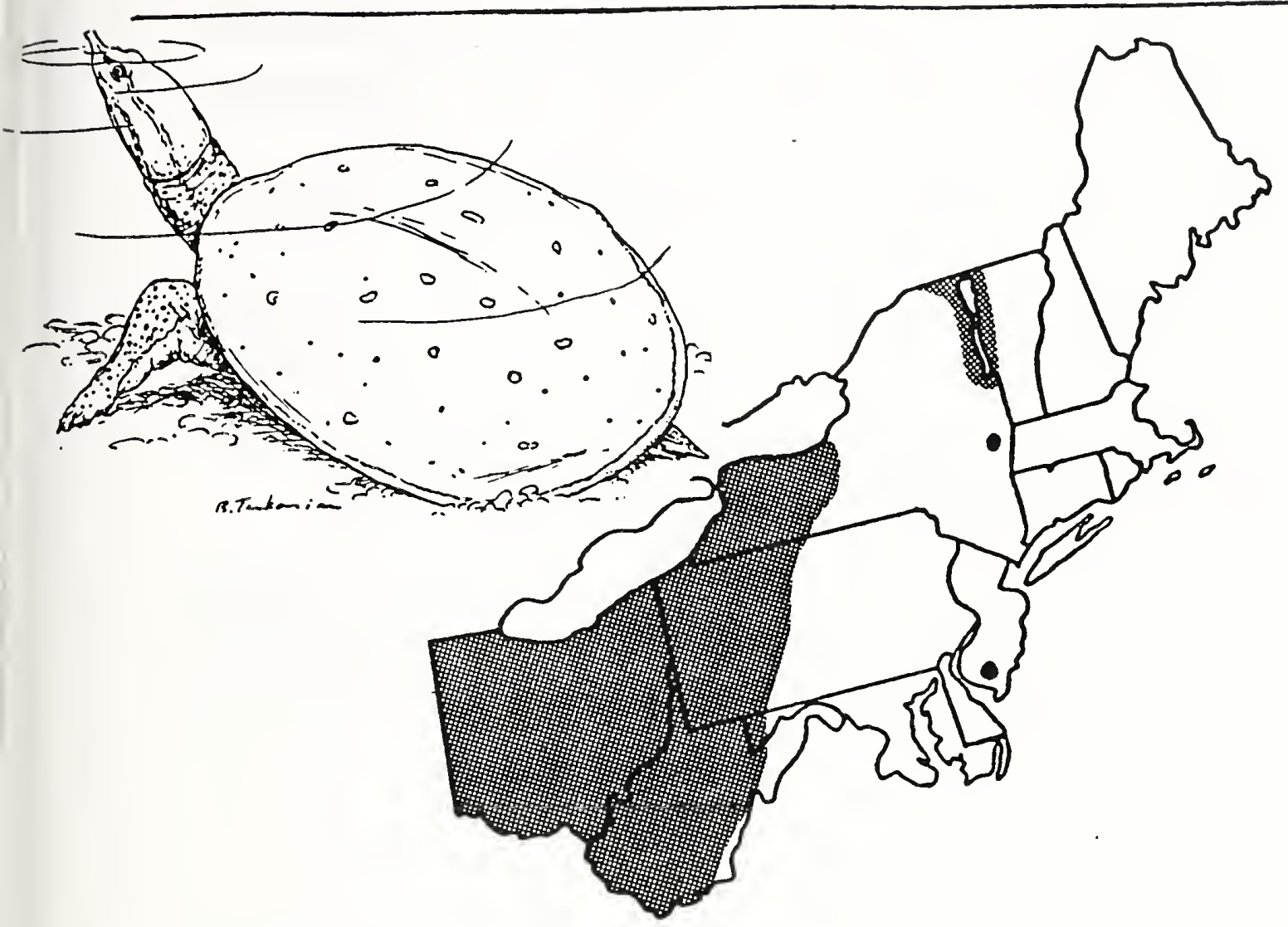

Range: Western New York across the Great Lakes States to the Mississippi River, $n$. Wisconsin south to the Tennessee River extending east to $c$. Pennsylvania. A disjunct colony occupies the Lake Champlain area. Introduces into the Maurice River system of New Jersey.

Relative Abundance in the Northeast: Uncommon.

Habitat in the Northeast: Aquatic, inhabiting large river systems. Also found in lakes and ponds. Intolerant of pollution from sewage, industrial or chemical wastes (Minton 1972:191). Basks on sand bars, mud flats, grassy beaches. Hibernates beneath 2 to 3 in $(5.1$ to $7.6 \mathrm{~cm}$ ) of river bottom mud from October to April in the North.

Special Habitat Requirements: Shallow muddy bottoms for burrowing. Some aquatic vegetation essential (N. Green, pers. observ.).

Age/Size at Sexual Maturity: Females with plastron length of 180 to $200 \mathrm{~mm}$, males at 90 to $100 \mathrm{~mm}$. 

Breeding Period: April or May.

Egg Deposition: May to August. Eggs laid in sandy soil or gravel beds near waters' edge.

Clutch Size: Typically 12 to 18, with a range of 4 to 32 eggs (Ernst and Barbour 1972:264).

Eggs Hatch: August to October or hatchlings overwinter in nest.

Home Range Size: Unreported.

Food Habits/Preferences: Chiefly carnivorous. Crayfish and insects are the major food items with tadpoles, frogs, mollusks, and

fish eaten less frequently; vegetation and other plant materials also consumed.

Comments: Somewhat nocturnal.

Selected References: Ernst and Barbour 1972, Minton 1972, Webb 1973. 



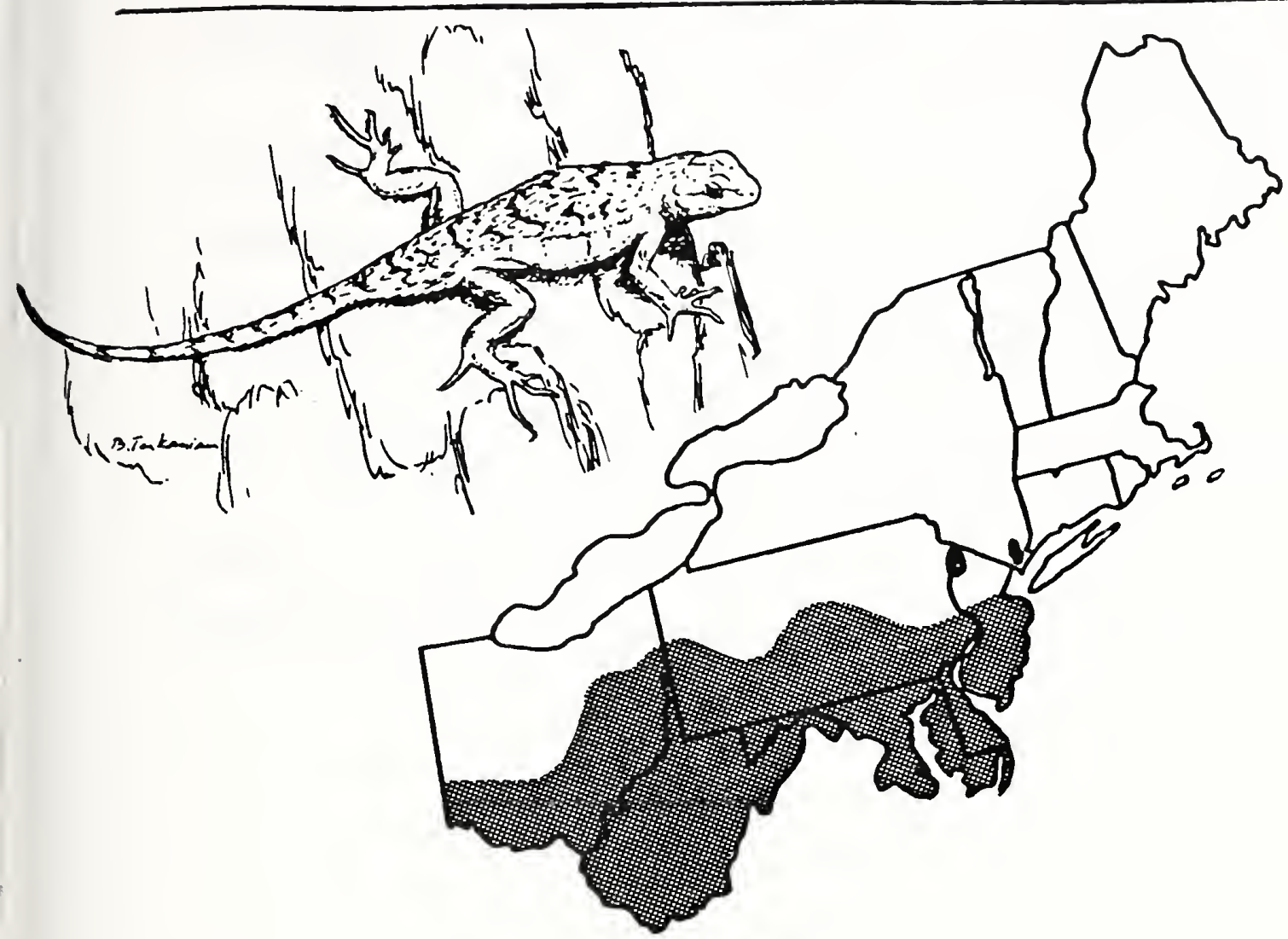

Range: New Jersey west to e. Kansas south to c. Texas and through c. Mississippi to South Carolina.

Relative Abundance in the Northeast: Rare, locally common in the New Jersey pine barrens.

Habitat in the Northeast: Dry, open, sunny woods. Found in brush piles, on fences, log piles, stumps, on buildings, usually near protective cover. Pine forests preferred, also found in oak-hickory and oakpine forests (Minton 1972:197). Hibernates in underground burrows, rock crevices, in rotted wood, usually from October to April.

Special Habitat Requirements: Dry, sunny locations with cover.

Age/Size at Sexual Maturity: Breeds at 20 months in Colorado and Ohio (Tinkle and Ballinger 1972).

Breeding Period: April to May, after emergence from hibernation.

Egg Deposition: Late May to early August, in Maryland 8 weeks after breeding (Smith 1946:225). 

Clutch Size: 4 to 17 eggs, laid in ground, preferably in sandy soil or decaying stumps. I to 3 clutches may be laid per year (Tinkle and Ballinger 1972). Clutch size varies with geographic location.

Incubation Period: 10 weeks.

Eggs Hatch: Late summer to early fall (Tinkle and Ballinger 1972).

Home Range/Movement: Males defend small territories during breeding season--actual area unknown.

Food Habits/Preferences: Insects, spiders, millipedes, snails, pseudoscorpions, other small invertebrates. Favors ants (Cagle 1945, Hamilton and Pollock 1961).

Comments: Arboreal and diurnal.

Selected References: Smith 1946, Smith 1961, Minton 1972. 



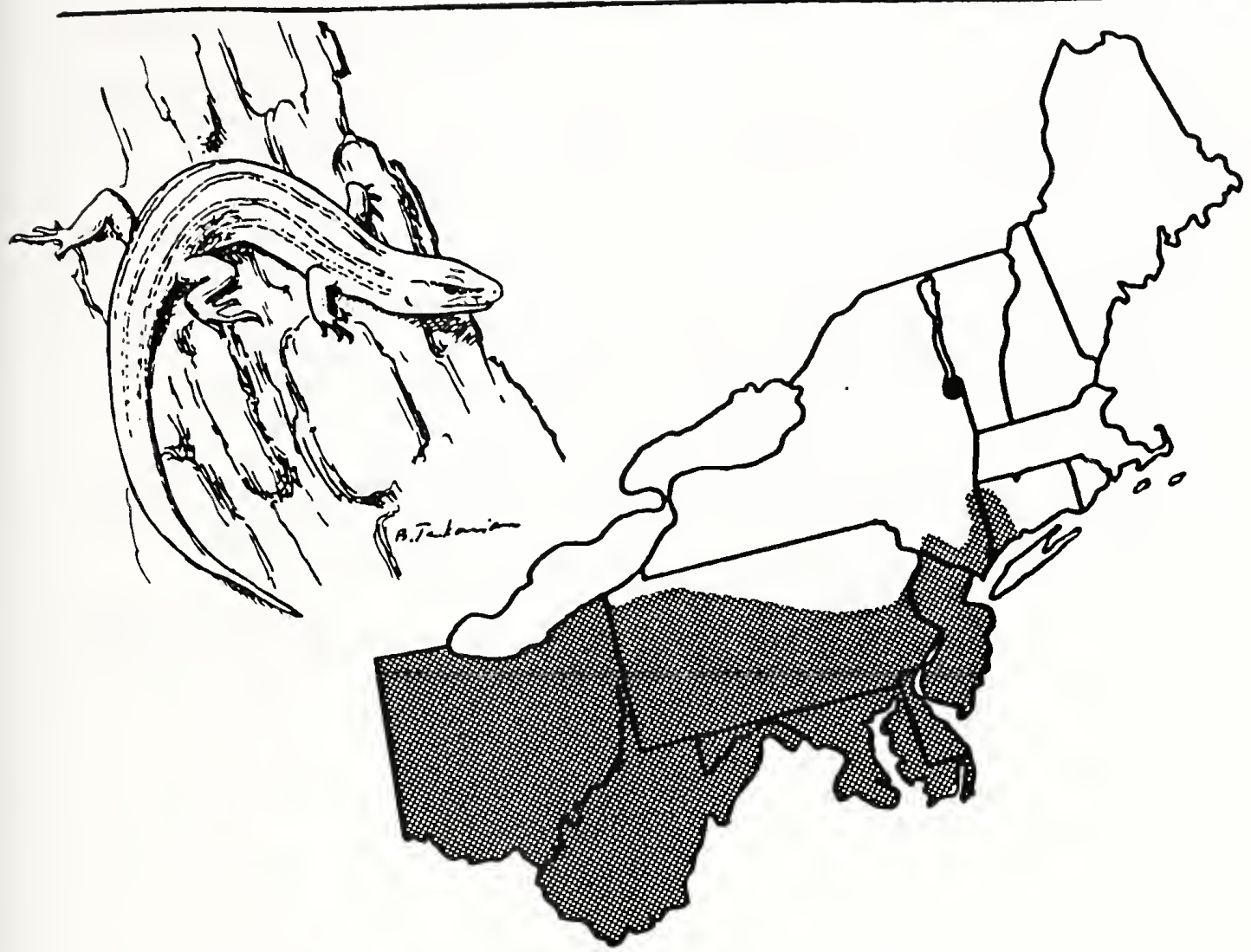

Range: Southern end of Lake George, New York and s.e. New York south to n. Florida, west to c. Texas. Northern limit from Pennsylvania, Ontario to $c$. Wisconsin and n. Missouri.

Relative Abundance in the Northeast: Rare in Northeast through Connecticut, peripheral in New Jersey, presumed extinct in Massachusetts. Common in Pennsylvania, Maryland and West Virginia.

Habitat in the Northeast: Mesic wooded areas, open or moderately dense with ground cover. Most abundant around old buildings and open woods. Frequently in damp spots, under logs, rock piles, leaf litter, sawdust piles. Suns for brief periods on warm days (Smith 1946:349). Found on open talus slopes in mixed deciduous woodlands, New York. Primarily terrestrial but will climb snags to find insects. Hibernates from October until mid-March in decaying logs or below the frost line, underground or under large rocks.

Special Habitat Requirements: Open woods with logs and slash piles.

Age/Size at Sexual Maturity: After second hibernation. 

Breeding Period: May.

Egg Deposition: Typically in June or July, 6 to 7 weeks after breeding (Smith 1956:193). Eggs laid under rocks, logs, in rotted stumps, in loose soil.

Clutch Size: 4 to 20 eggs (Barbour 1971:209), typically 9 to 12 .

Home Range/Movement: Males home range diameter about $90 \mathrm{ft}(27.4 \mathrm{~m})$, females about $30 \mathrm{ft}(9.1 \mathrm{~m})$, in e. Kansas (Fitch 1954 cited in Minton 1972:210). Individuals may remain in same home range or move after emerging from hibernation.

Food Habits/Preferences: Primarily insects and spiders, also snails, grubs, small vertebrates including young mice. Lizards occasionally eaten; will eat its own shed skin.

Selected References: Smith 1946, 1956; Barbour 1971. 

Northern Coal Skink

Eumeces a. anthracinus
Squamata

Lacertilia

Scincidae

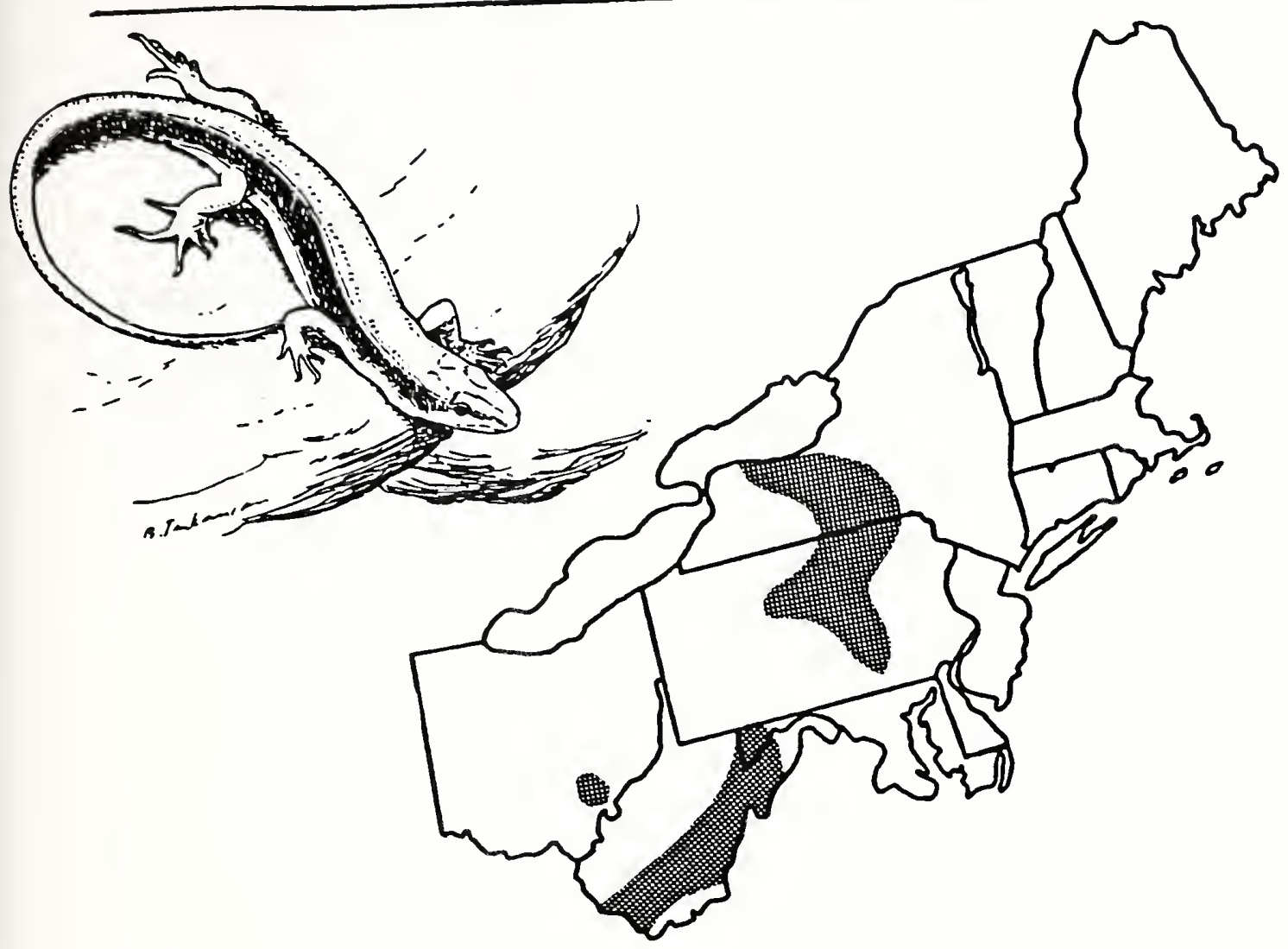

Range: Scattered populations in w. New York and Pennsylvania, Ohio, Virginias and Kentucky.

Relative Abundance in the Northeast: Uncommon.

Habitat in the Northeast: Damp wooded hillsides, near swamps, around wood piles, loose boulders, rotted logs. Will hide in shallow water.

Prefers humid areas. Found in chestnut-oak-poplar woods (Smith and Smith 1952 cited in Minton 1972:331). West Virginia populations found in shale barrens (N. Green, pers. observ.).

Special Habitat Requirements: Humid areas with cover.

Age/Size at Sexual Maturity: Unreported.

Breeding Period: April to May in New York (Smith 1946:374).

Egg Deposition: June, guarded by female. 

Clutch Size: 8 to 9 eggs.

Eggs Hatch: 4 to 5 weeks.

Home Range/Movement: Unreported.

Food Habits/Preferences: Insects and their larvae.

Comments: Diurnal.

Selected References: Smith 1946. 



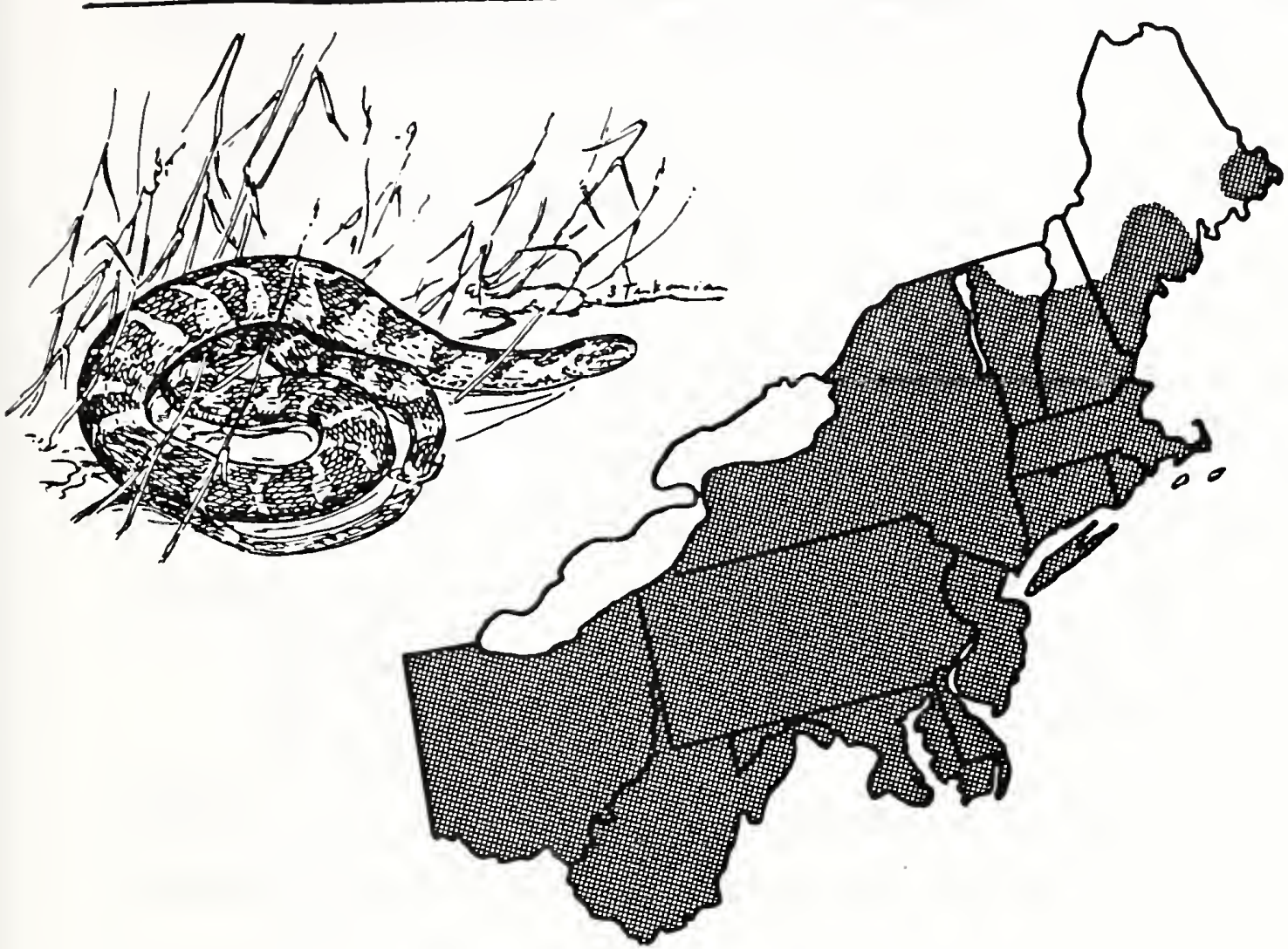

Range: Southern Maine, s. Ontario to $n$. Wisconsin, south through Kansas to e. Colorado, n. Oklahoma to c. Indiana, Kentucky, and Tennessee east to North Carolina and New England.

Relative Abundance in the Northeast: Abundant in suitable habitat.

Habitat in the Northeast: Aquatic and semi-aquatic habitats, favors

spillways and bridges where rocks provide close cover, uncommon in deeply shaded woodland swamps and ponds, probably due to lack of basking sites ( $M$. Klemens, pers. commun.). Found in the vicinity of rivers, brooks, wet meadows, ponds, swamps, bogs, old quarries. Inhabits salt or fresh water (Wright and Wright 1957:513), absent from heavily polluted waters. Prefers still or slow-moving water. Hibernates in crevices of rocky ledges, or in banks adjacent to water habitat.

Special Habitat Requirements: Branches or logs overhanging the water, or boulders of dams and caveways in reservoirs ( $T$. Tyning, pers. commun.). 

Age/Size at Sexual Maturity: Males 635 to 1,148 mm, females at 650 to 1,295 mm (Wright and Wright 1957:513).

Breeding Period: April to May and early fall.

Young Born: August to early October. Viviparous.

No. Young: 10 to 76 young, average 20 to 40 . Larger females have Targer litters.

Home Range/Movement: One individual moved $380 \mathrm{ft}(115.8 \mathrm{~m})$ along a river after 2 years (Stickel and Cope 1947). In large ponds at an Indiana fish hatchery, $80 \%$ were recaptured in the same pond, $89 \%$ were in the same pond or an adjacent pond. Snakes along streams had larger home ranges (Fraker 1970).

Food Habits/Preferences: Cold-blooded vertebrates: fish comprise $61 \%$ of food items, frogs and toads $21 \%$, salamanders $12 \%$; also insects, crayfish, recently dead fish (Uhler et al. 1939). Fish comprise over $95 \%$ of diet (Raney and Roecker 1947). May occasionally take shrews and mice.

Comments: Frequently found basking. Active both day and night.

Selected References: Schmidt and Davis 1941, Wright and Wright 1957. 



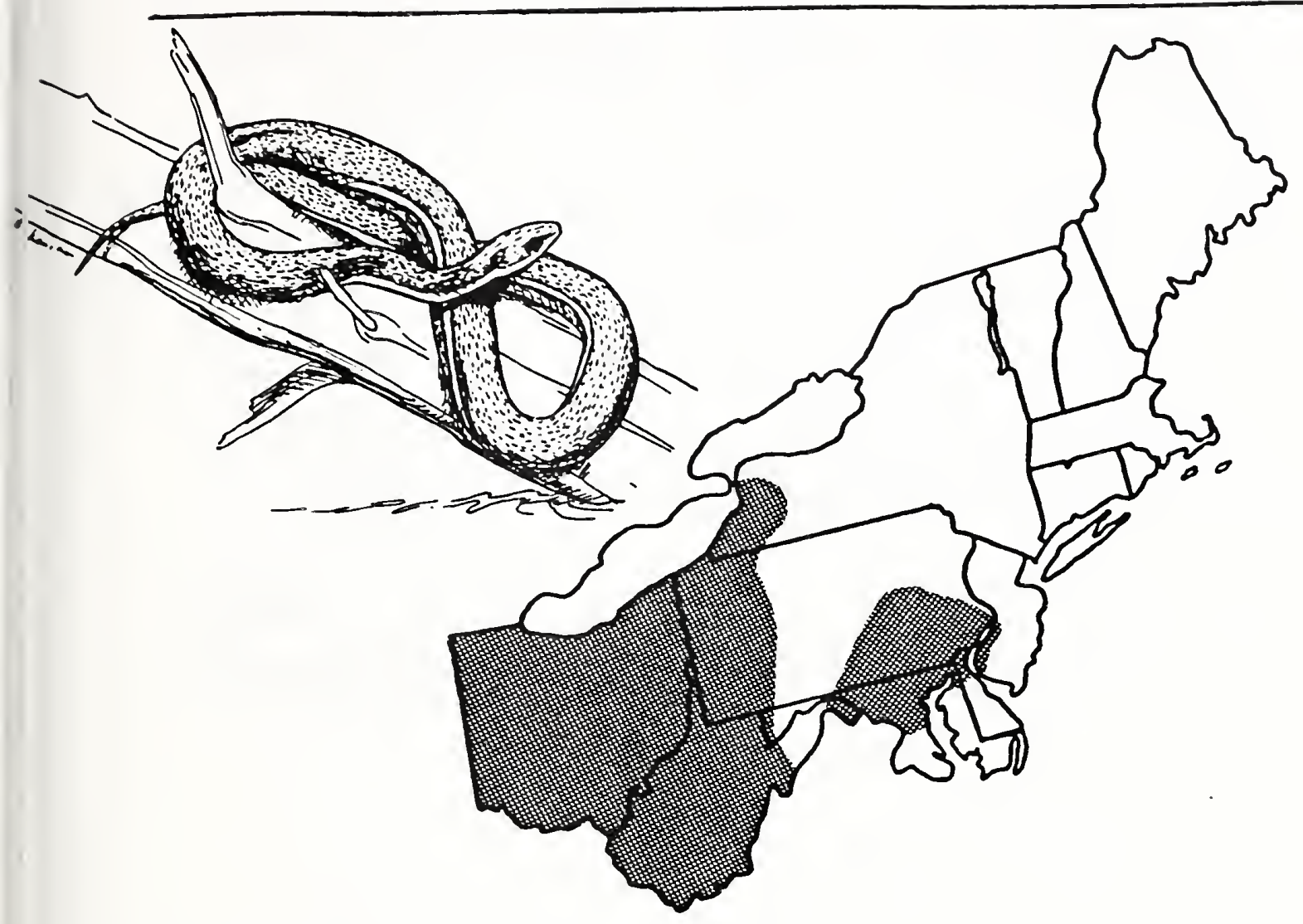

Range: Southwestern New York, s.e. Ontario, c. Michigan to s.e. Wisconsin, south to $c$. Mississippi, the panhandle of Florida and north through c. Georgia to s. Pennsylvania. Disjunct population in Missouri and Arkansas.

Relative Abundance in the Northeast: Locally abundant.

Habitat in the Northeast: Edges of sma11, clear, permanent streams, rivers and ponds in forested regions; also around canals, ditches, old quarries. Found in both swift and slow-moving waters. Found among aquatic plants, overhanging shrubs at shallow edges or among rocks and other debris at the water line. During summer months found in the water or under rocks (Wood 1949). Hibernates November to March in large aggregations, sometimes under rocks (Wright and Wright 1957:507).

Special Habitat Requirements: Aquatic habitats with moving water. 



\section{Queen Snake}

Age/Size at Sexual Maturity: Summer after third hibernation (Wood 1949), males 375 to $692 \mathrm{~mm}$, females 375 to $787 \mathrm{~mm}$ (Wright and Wright $1957: 508)$.

Breeding Period: Soon after emergence in the spring, also during the fall in Michigan (M. Klemens, pers. commun.).

Young Born: 5 to 23 (Wood 1949), typically 10 to 12.

Home Range/Movement: Unreported.

Food Habits/Preferences: Recently molted crayfish taken almost exclusively (Raney and Roecker 1947), but occasionally toads, snails, small fish, newts, and insect larvae (Wright and Wright 1957:509).

Comments: Very aquatic; diurnal.

Selected References: Schmidt and Davis 1941, Wood 1949, Wright and Wright 1957 . 



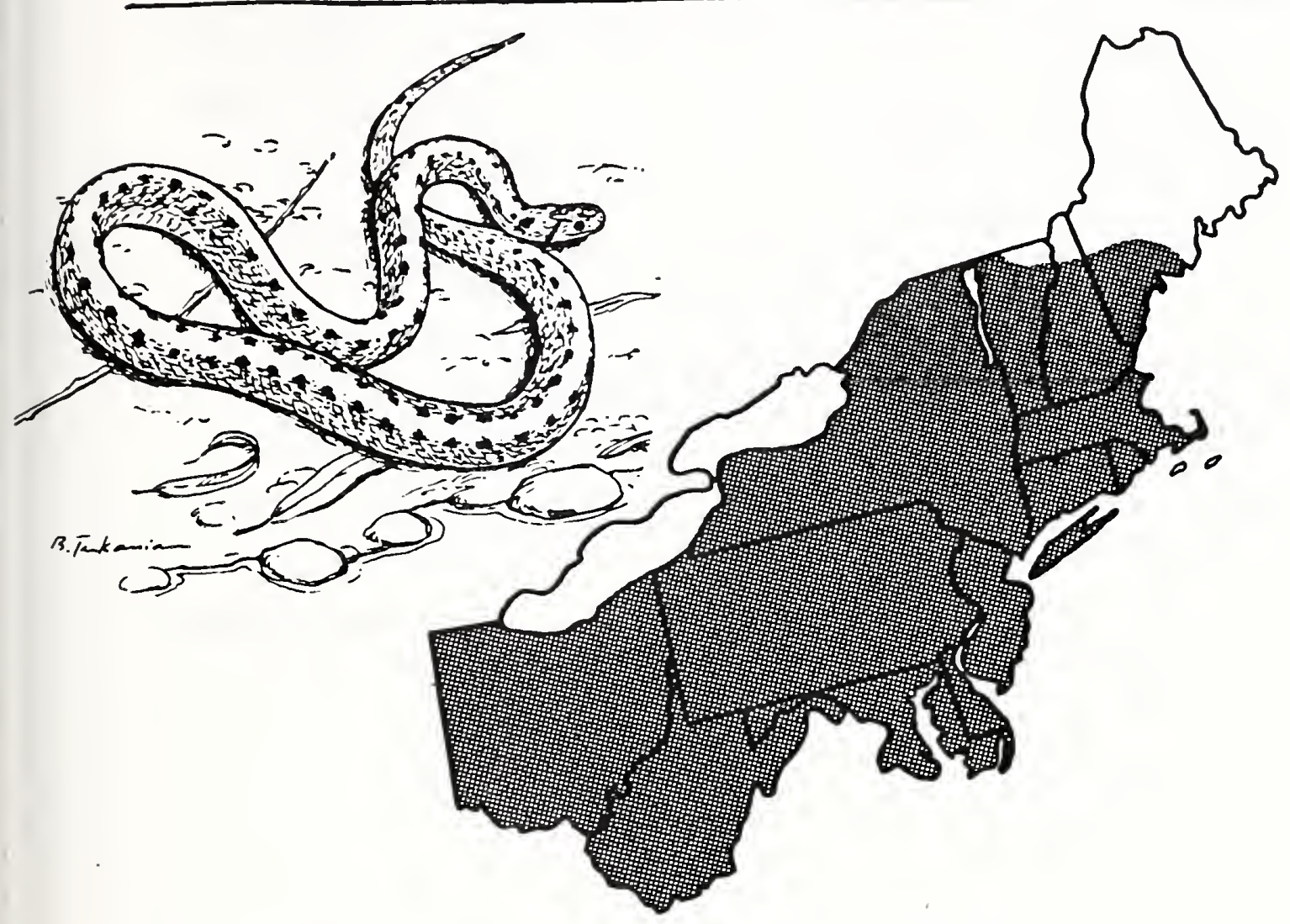

Range: Eastern U.S. from S. Maine and s. Canada west to Michigan, south to South Carolina. Range overlaps that of the Midland brown snake.

Relative Abundance in the Northeast: Common.

Habitat in the Northeast: Ubiquitous, found in urban and rural areas, dry or moist situations, vacant lots, parks, trash piles. May be abundant along railroad tracks ( $T$. Tyning, pers. commun.). In the wild found in damp woods, swamps, clearings, bogs, roadsides, open fields. Hides under stones, banks, logs, brush piles, leaves. Rare in old growth forests (J. Lazell, pers. commun.). Hibernates in large groups from October to November until March or April; may use ant hills or abandoned mammal burrows.

Age/Size at Sexual Maturity: At 2 years (Noble and Clausen 1936).

Breeding Period: Late March to April and possibly in the fall.

Young Born: Late July to August, at least 3 months after breeding (Wright and Wright 1957:701). Viviparous. 

No. Young: 3 to 24 young (Smith 1956:283), typically 14 .

Home Range/Movement: Average daily movement of 10 to $15 \mathrm{ft}(3.0$ to $4.6 \mathrm{~m})$ on Long Island. Thirteen of 32 individuals displayed homing behavior (Noble and Clausen 1936).

Food Habits/Preferences: Slugs, snails, earthworms, insects, minnows, and tiny toads are occasionally eaten.

Comments: Formerly DeKay's snake. Commonly found in aggregations throughout the year (Noble and Clausen 1936). May appear to be scarce during July and August when it moves down into soil to lower temperature zones. Degree of fossorial tendency varies with microhabitat temperature preference (Elick et al. 1979). Active evening to early morning; one of the few New England snakes that is active at night.

Selected References: Schmidt and Davis 1941, Wright and Wright 1957. 



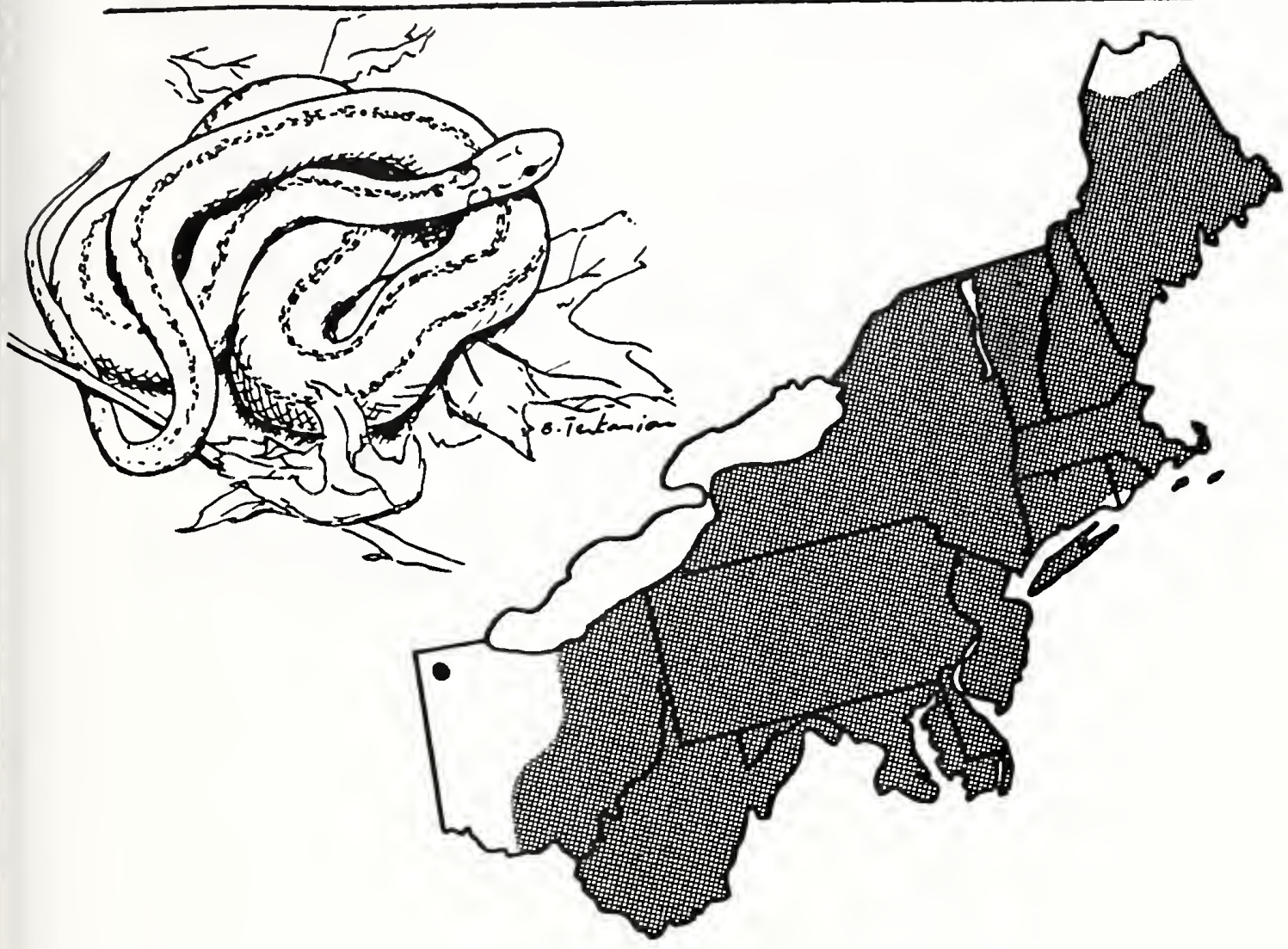

Range: Nova Scotia to s. Manitoba, south to e. Texas, Georgia, and throughout the e. U.S.

Relative Abundance in the Northeast: Locally abundant.

Habitat in the Northeast: Moist woods, hillsides, sphagnum bogs, upland meadows and valleys. Found under surface debris, also around abandoned buildings. Occurs at elevations from sea level to mountains. Prefers woodlands: pine, oak-hickory, aspen, hemlock groves (Wright and Wright 1957:717). More frequently found in upland woody ridges. Hibernates from fall to March or April. Active through mid-October in Connecticut (M. Klemens, pers. commun.).

Special Habitat Requirements: Woodlands.

Age/Size at Sexual Maturity: Males 182 to $359 \mathrm{~mm}$, females 211 to $383 \mathrm{~mm}$ (Wright and Wright 1957:718), at 2 years (Blanchard 1937a).

Breeding Period: Probably after emerging from hibernation; a late summer or fal1 mating may also occur (Barbour 1971:287). 

Young Born: August to September. Viviparous.

No. Young: 1 to 14 young (Blanchard 1937a), typically 7 to 8.

Home Range/Movement: 1 adult found $100 \mathrm{ft}(30.4 \mathrm{~m})$ from release point in Michigan after 7 days (Blanchard 1937a).

Food Habits/Preferences: Consumes slugs, earthworms, soft insects and larvae, sowbugs; occasionally small salamanders.

Comments: Has been found active at all times of day and evening. Degree of fossorial tendency varies (E1 ick et al. 1979). Young commonly mistaken for young ring-neck or Northern brown snakes.

Selected References: Schmidt and Davis 1941, Wright and Wright 1957, Barbour 1971. 



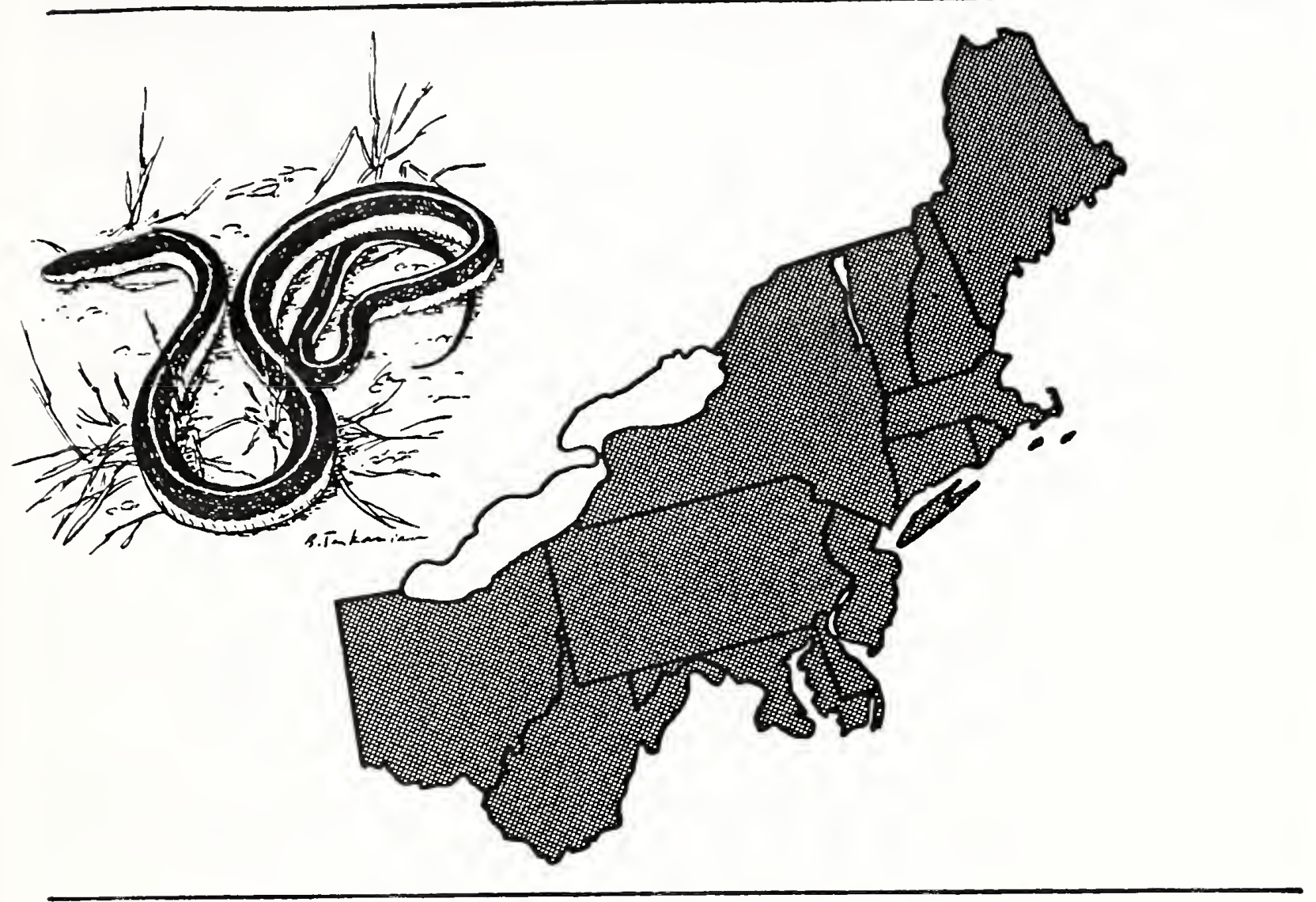

Range: Nova Scotia to e. Manitoba south to e. Texas, and throughout the e. U.S.

Relative Abundance in the Northeast: Very abundant; most common and widespread snake.

Habitat in the Northeast: Ubiquitous, terrestrial; found in moist areas, forest edges, stream edges, fence rows, vacant lots, bogs, swamps, overgrown yards. Usually avoids thickly forested areas. One specimen found under a rock in a stream through a dark hemlock grove (M. Klemens, pers. commun.). Found in almost all damp environments, from river bottoms to mountain elevations.

Hibernates in holes, rock crevices, mud, anthills, rotted wood, uprooted trees, house foundations, and sometimes partially or completely submerged under streambed rocks, from October to March or April. One of the earliest snakes to emerge from hibernation.

Age/Size at Sexual Maturity: Females in second year, some males the second spring after birth (Carpenter 1952a). At $400 \mathrm{~mm}$ snout to vent length for males and $500 \mathrm{~mm}$ for females in Kansas (Fitch $1965: 531)$. 

Breeding Period: After emergence from hibernation in mid-March to May, also in fall before hibernation (Anderson 1956:169). Mates at or near hibernation site.

Young Born: July to early September. Gestation period of 3 to 4 months or longer in cooler climates (Blanchard and Blanchard 1942). Viviparous.

No. Young: 3 to 85 young, typically 14 to 40 . Number of young correlated with size and age of female (Fitch 1965:558).

Home Range/Movement: Approximately 5 ac (2.0 ha), most ranges were smaller in cut-over agricultural fields in Indiana. Activity range* of about 2 ac $(0.8 \mathrm{ha})$ in Michigan woodlands and open fields (Carpenter 1952a). Home ranges of 35.0 ac (14 ha) for males and $22.2 \mathrm{ac}(9.1 \mathrm{ha})$ for females were found in mixed habitat in Kansas (Fitch 1965:538). Many individuals migrate from hibernacula to summer ranges.

Food Habits/Preferences: Earthworms comprise $80 \%$ of food items, also amphibians, carrion, fish, leeches, caterpillars, other insects, small birds, rodents (Carpenter 1952b); also slugs, other snakes, mollusks, crayfish, sowbugs (Hamilton 1951).

Comments: Diurnal but sometimes active at night (Minton 1972:250). Seeks cover under objects on hot summer days. Pesticides have reduced local populations in New York (Gochfeld 1975).

Selected References: Carpenter 1952b, Wright and Wright 1957, Fitch 1965.

* Defined as an area covered by an animal in the course of its day-to-day existence. Lacks definite home site or other center of activity (Carpenter 1952b:250). 



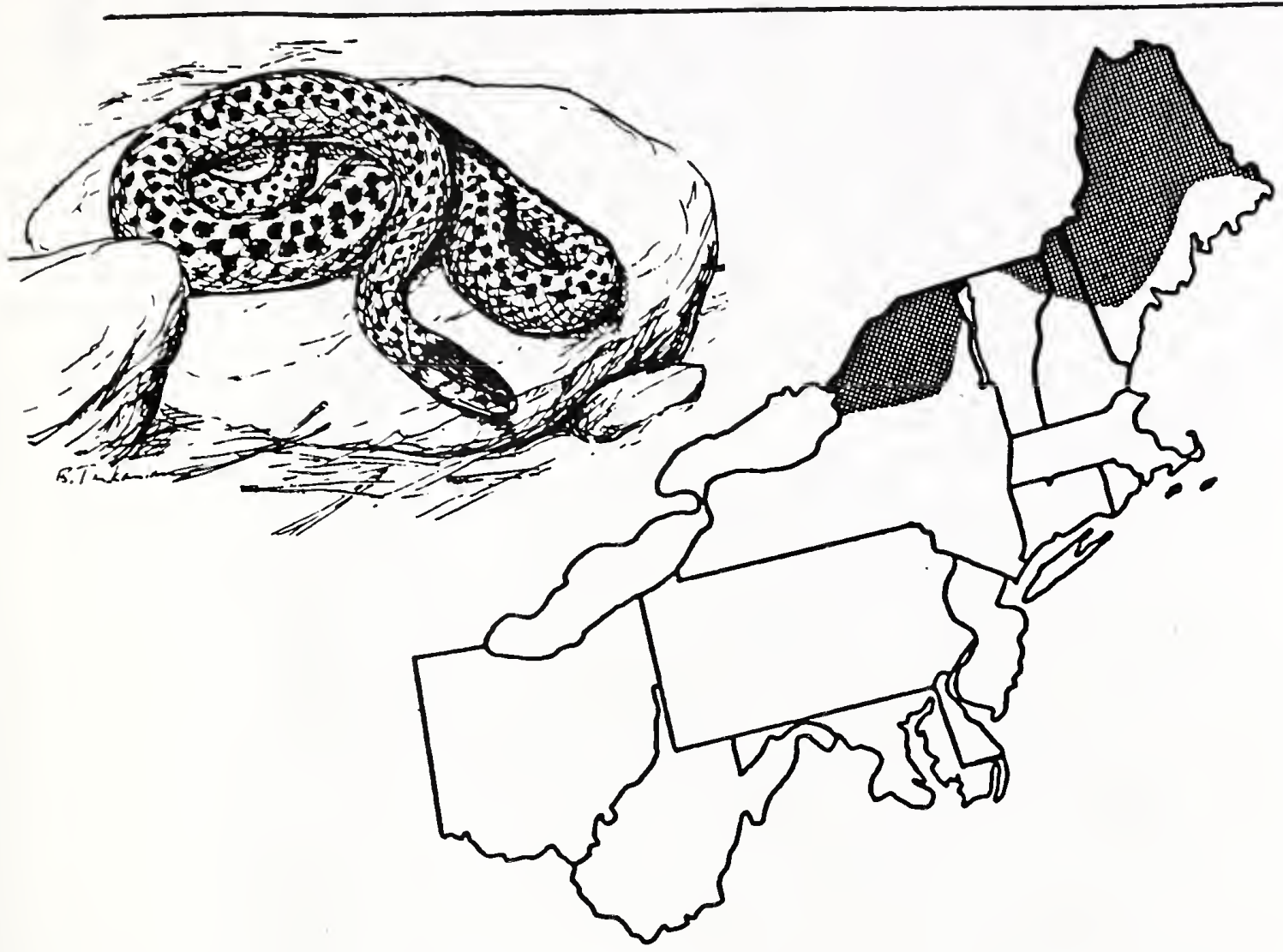

Range: Eastern Quebec extending to Alberta in discontinuous populations, south to $n$. New Hampshire, New York and $n$. Michigan. Intergrades with T. S. sirtalis to west and s. parts of range.

Relative Abundance in the Northeast: Unreported.

Habitat in the Northeast: Undocumented.

Comments: Little information available on life history.

Selected References: Bleakney 1959. 



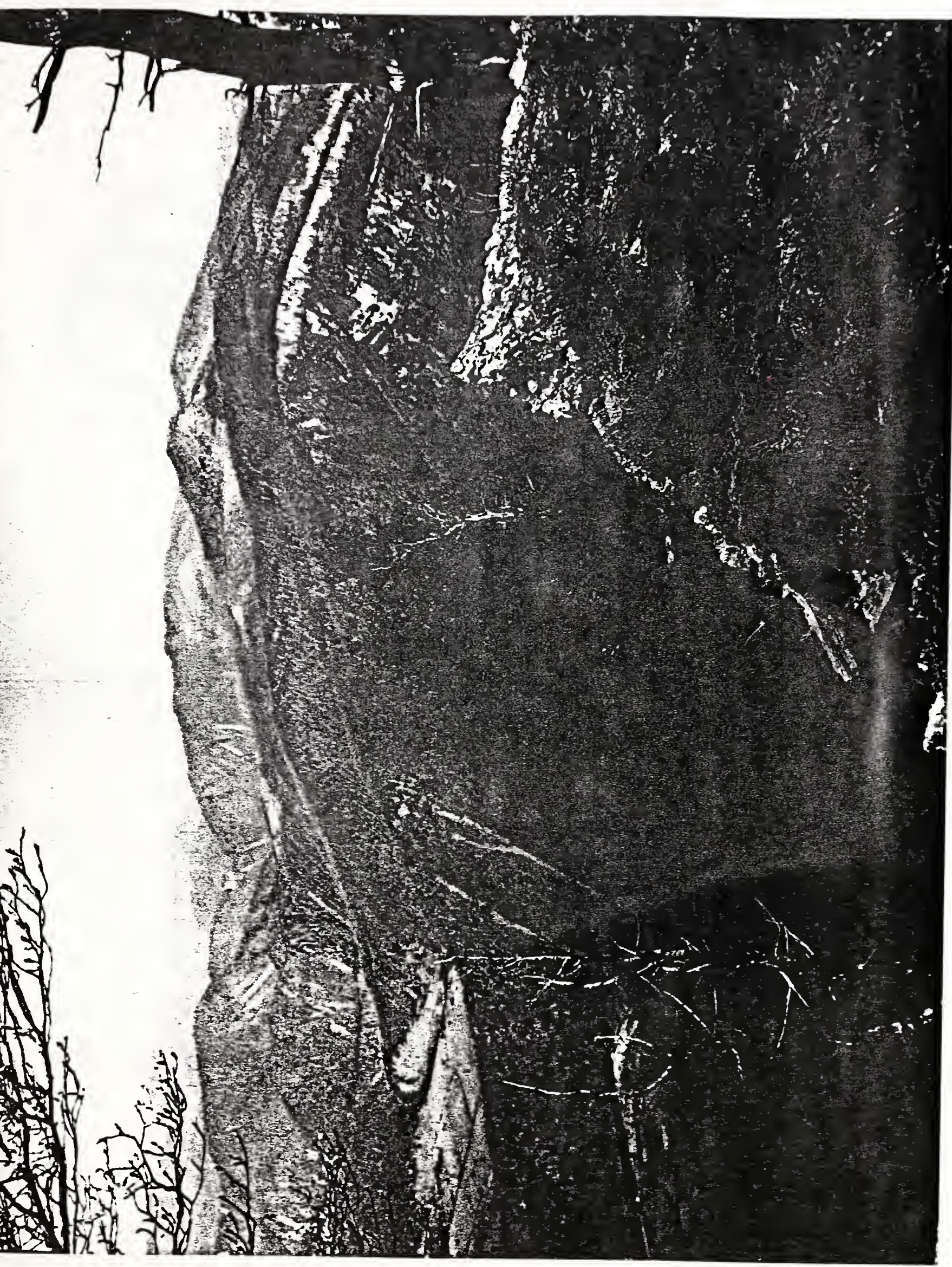





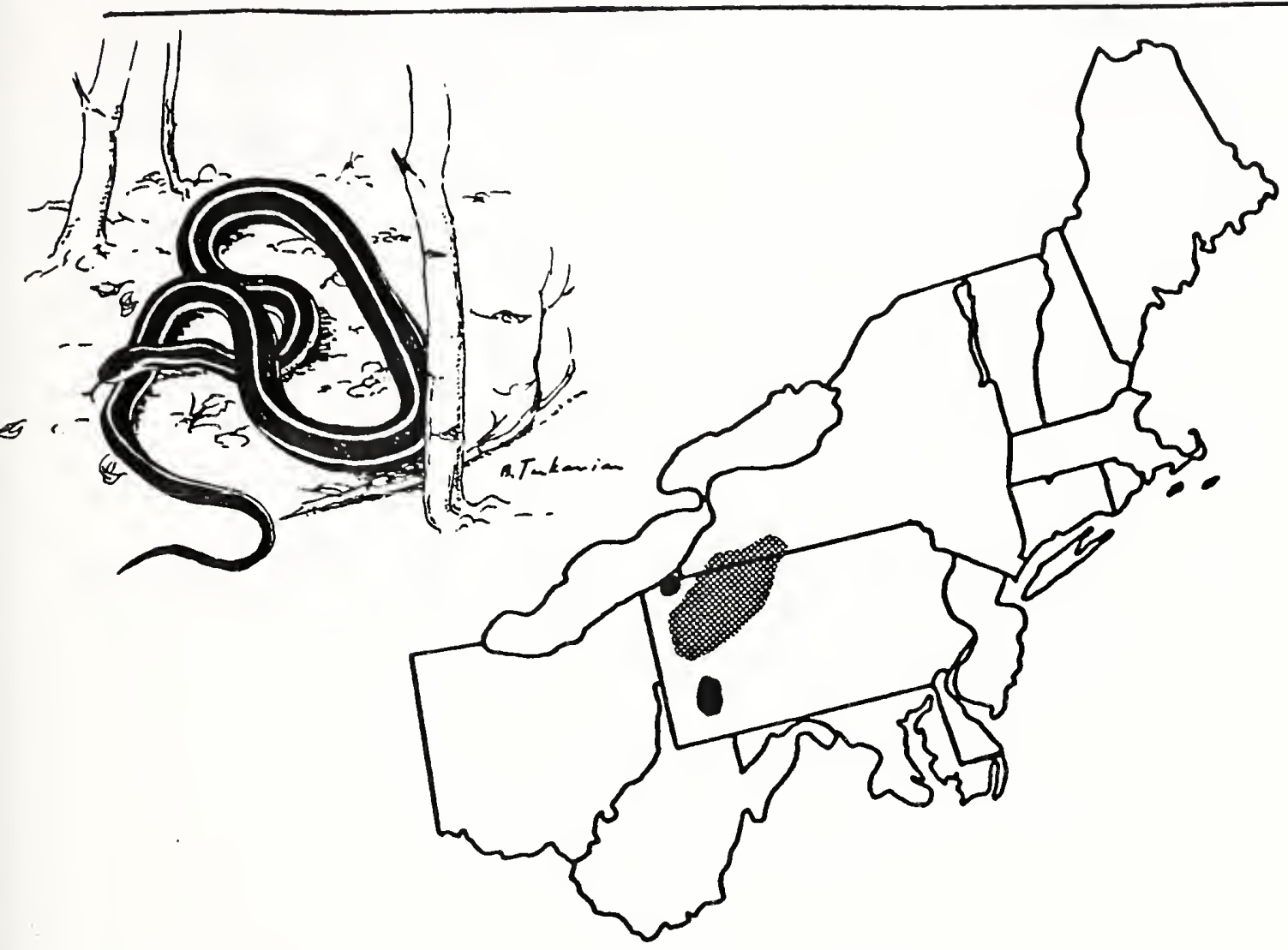

Range: The Allegheny High Plateau of extreme s.w. New York and n.w. Pennsylvania.

Relative Abundance in the Northeast: Abundant.

Habitat in the Northeast: Areas with brushy cover or piles of stones, creek borders, old fields, meadows; near or in water, uplands and lowlands. Prefers open herbaceous areas, may be occasionally found into the forest edge. Moist grassy areas and dry rocky slopes (Stewart 1961:78). Dry pastures to beaver pond marshes (Kl ingener 1957). Hibernacula for 13 individuals in New York was a shale outcropping on a bluff (Bothner 1963).

Special Habitat Requirements: Usually found near water.

Age/Size at Sexual Maturity: Males 290 to $440 \mathrm{~mm}$, females 250 to $506 \mathrm{~mm}$ (Wright and Wright 1957:815). 

Breeding Period: Unreported.

Young Born: August to September, Pennsylvania (Swanson 1952). Viviparous.

No. Young: 6 to 14 young, average 8 to 9 (Swanson 1952).

Home Range/Movement: Undocumented.

Food Habits/Preferences: Earthworms (Asplund 1963). Frogs, fish, toads, mice, earthworms, insects (Collins 1959:390).

Comments: Extremely docile and gregarious (Stewart 1951:78-79, Swanson 1952).

Selected References: Swanson 1952, Wright and Wright 1957, Bothner 1976. 



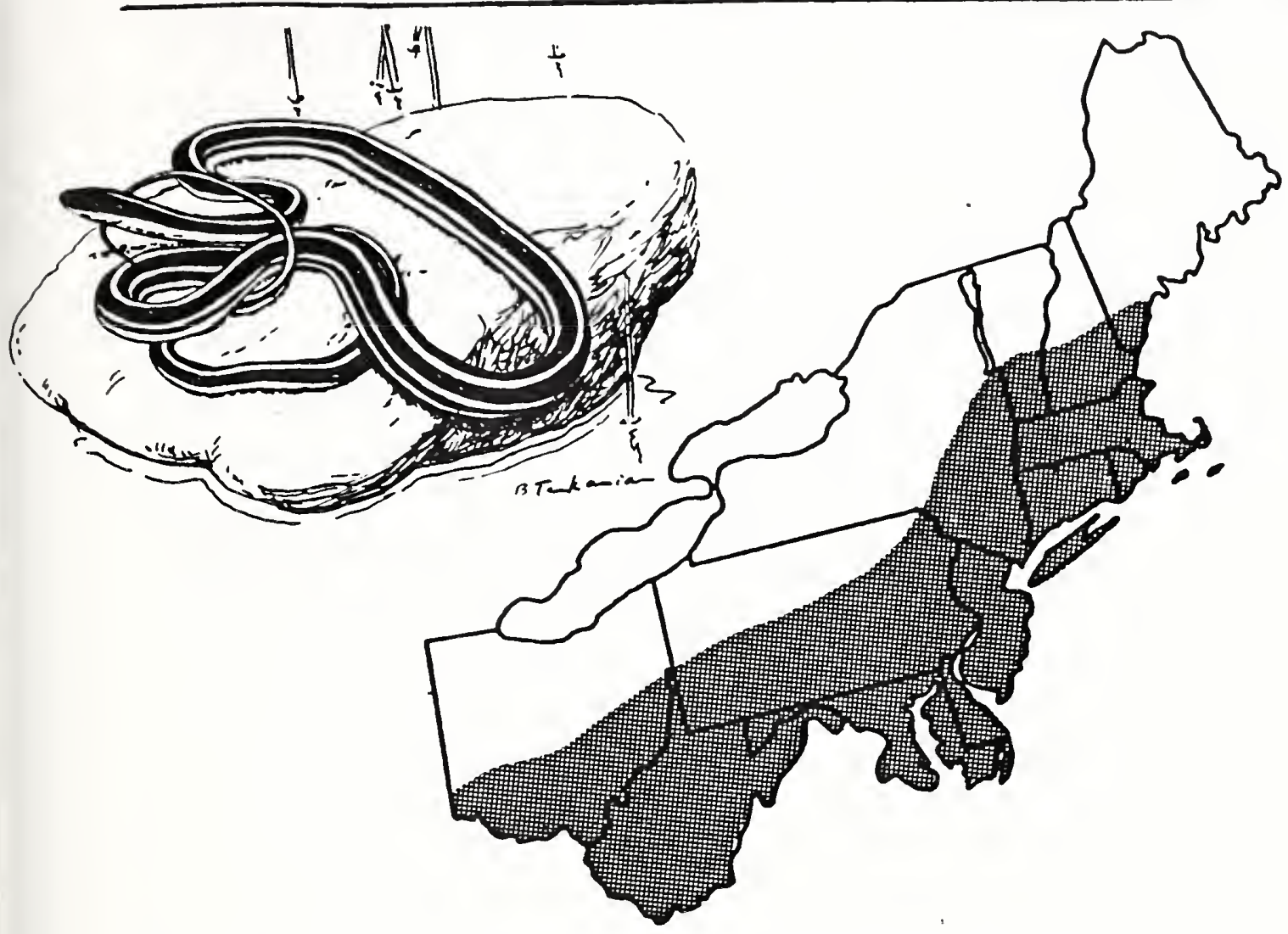

Range: Southern Maine to South Carolina and the Florida panhandle. Southern Indiana south to e. Louisiana. Northern 1 imits through s. Indiana to c. New England.

Relative Abundance in the Northeast: Generally common, but uncommon in Connecticut (M. Klemens, pers. commun.).

Habitat in the Northeast: Semi-aquatic, inhabiting stream edges, swampy areas, wet meadows, ponds, bogs, ditches. Prefers areas with brushy vegetation at waters' edge for concealment. Also in damp or wet deciduous or northern pine forests. Seldom far from cover (Carpenter 1952b). May escape higher ground temperatures in summer by seeking shelter in shrubs or underground. Hibernates from October to March (Wright and Wright 1957:825).

Special Habitat Requirements: Mesic woodlands with aquatic habitat.

Age/Size at Sexual Maturity: Females during second year (Carpenter 1952a), males 400 to $819 \mathrm{~mm}$, females 451 to $900 \mathrm{~mm}$ (Wright and Wright 1957: 825). 

Breeding Period: After emergence from hibernation.

Young Born: Late JuTy to September, viviparous.

No. Young: 3 to 20 , typically 10 to 12 .

Home Range/Movement: Average activity range of about 2 ac (0.8 ha), in open Michigan grassland and traveled was $280 \mathrm{ft}(85.3 \mathrm{~m})$

Food Habits/Preferences: Frogs, toads and salamanders comprise $90 \%$ were taken; also milly smaller or metamorphosizing individuals (Carpenter 1952b).

Selected References: Carpenter 1952b, Rossman 1970. 



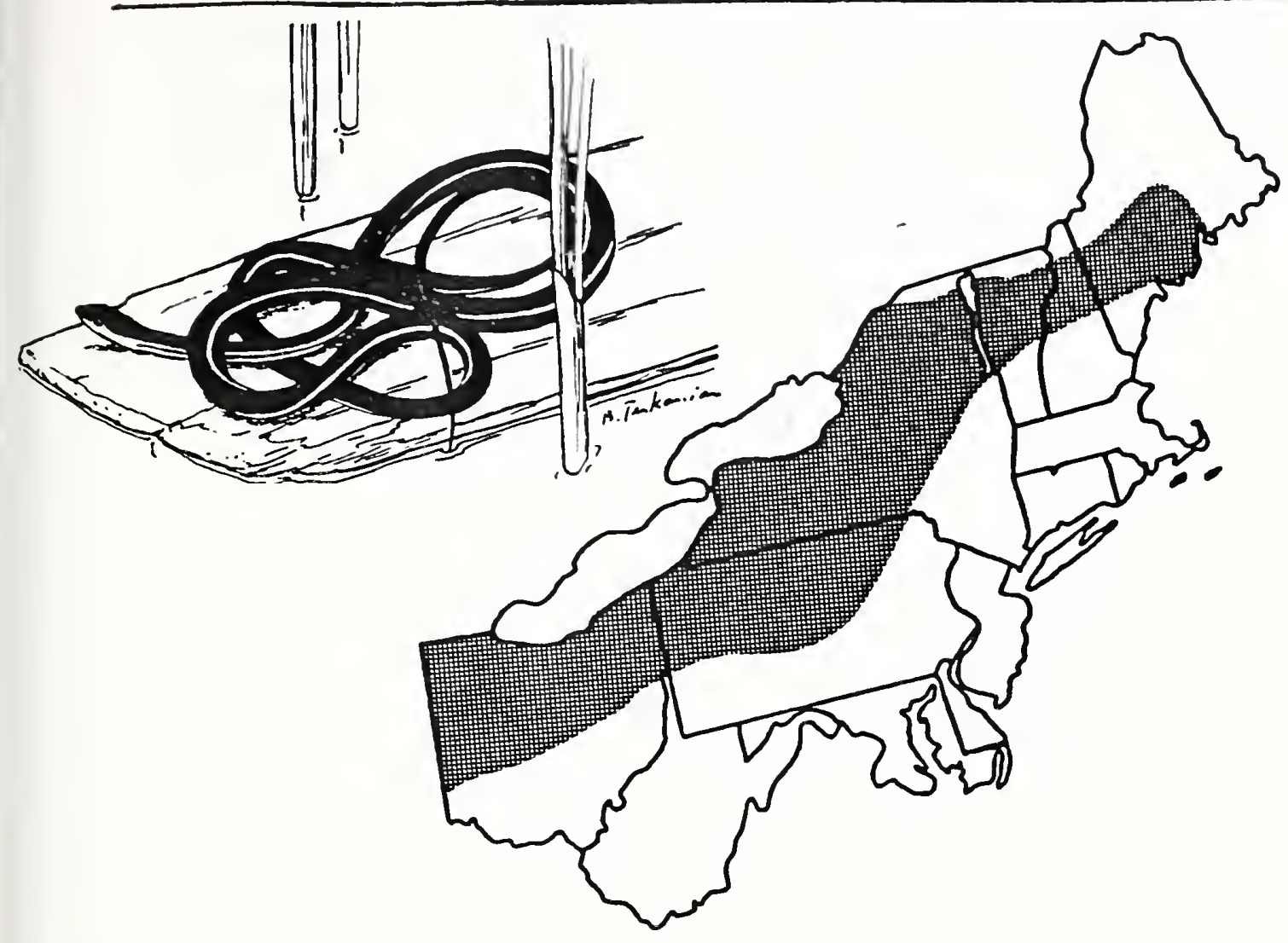

Range: Central Maine west through n.w. New England and s. Ontario to Michigan, south to s.e. Illinois, Indiana, Ohio and n. Pennsylvania.

Relative Abundance in the Northeast: Rare.

Habitat in the Northeast: Sunny areas with low, dense vegetation that is near bodies of shallow quiet water. Damp meadows, grassy marshes, northern sphagnum bogs, borders of ponds, lakes and meandering creeks. Semi-aquatic. Probably hibernates October to March (Minton 1972:260).

Special Habitat Requirements: Shallow, permanent water in open, grassy habitat.

Age/Size at Sexual Maturity: Some females at almost 2 years (Carpenter 1952a).

Breeding Period: Probably spring and fall (Minton 1972:260).

Young Born: July to August (Minton 1972:260). 

No. Young: 4 to 10 or 11 young (Minton 1972:260). Viviparous. Home Range/Movement: Unknown.

Food Habits/Preferences: Frogs, salamanders, fish. Captives will eat minnows. Brown (1979) noted that 93\% of the food items in 21 stomachs were comprised of anurans.

Comments: Diurnal.

Selected References: Minton 1972, Conant 1975. 



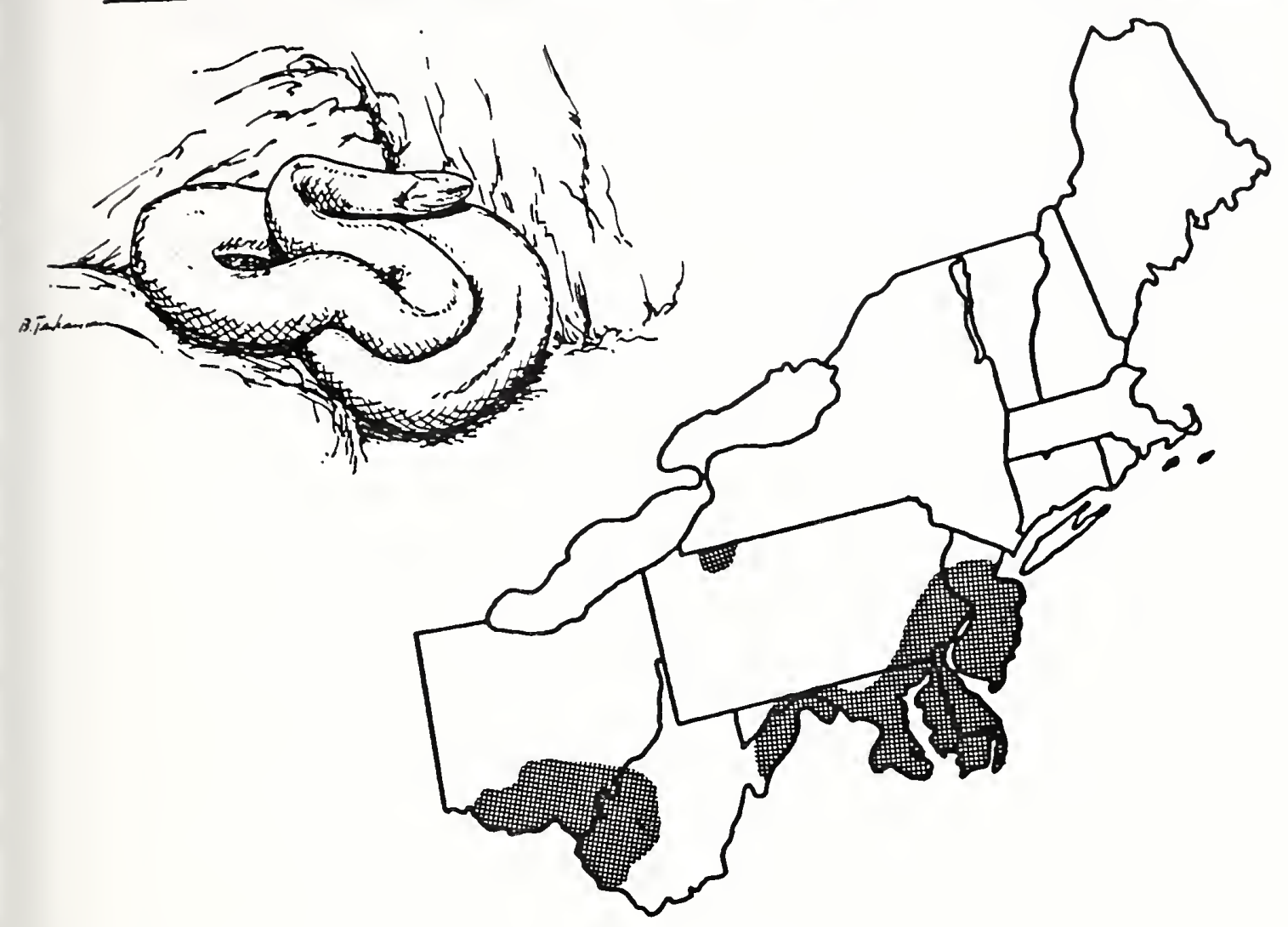

Range: Northern New Jersey west to s. Ohio and e. Kentucky, south to Alabama and the Florida panhandle and $n$. Florida. Absent from the Appalachian highlands.

Relative Abundance in the Northeast: Locally common, rare in New Jersey.

Habitat in the Northeast: Abandoned fields, open wooded hillsides, trails and woodland roads. Has also been found in vacant lots, dry deciduous and pine woods, wet meadows, woodland pastures. Hides under boards, trash, logs, sun-warmed stones. Hibernates during fall and winter months.

Special Habitat Requirements: Open habitat in woodlands or fields.

Age/Size at Sexual Maturity: Males 190 to $255 \mathrm{~mm}$, females 183 to $280 \mathrm{~mm}$ (Wright and Wright 1957:291).

Breeding Period: Probably early spring (Barbour 1971:283).

Young Born: Late July to August (Barbour 1971:283). Viviparous. 

No. Young: 7 to 10 (Wright and Wright 1957:291).

Home Range/Movement: Undocumented.

Food Habits/Preferences: Earthworms, snails, soft-bodied insects and their larvae and other small arthropods.

Comments: Secretive, nocturnal and semi-fossorial. Seldom seen above ground in the North except after heavy, cool rains.

Selected References: Wright and Wright 1957. 



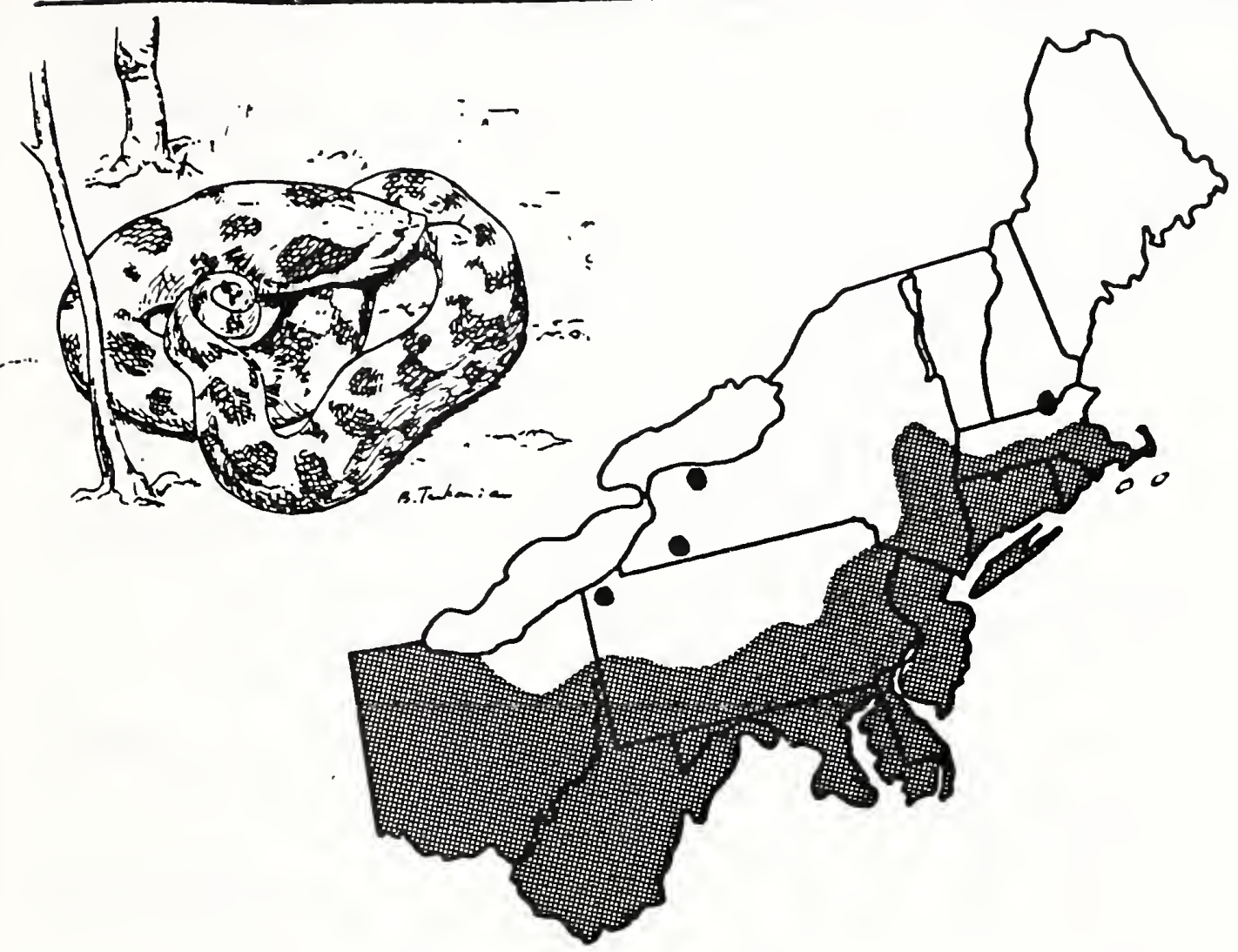

Range: Cape Cod and c. Massachusetts west to Ohio, s. Ontario, c. Minnesota, and s.e. South Dakota, south to c. Texas and s. Florida.

Relative Abundance in the Northeast: Locally common.

Habitat in the Northeast: Where sandy soils predominate, such as beaches, open fields, dry, open pine or deciduous woods. Has been found on hillsides, farm fields and around outbuildings. In Pennsylvania most frequently found in upland situations, intermountain and river valleys (McCoy and Bianculii 1966). Low-lying areas of Connecticut (M. Klemens, pers. commun.), and in marshy woodlands in the Albany Pine Bush in New York, and wooded creek bottomlands (M. Stewart, pers. commun.). Hibernates from late September to April or May under forest floor debris, stumps, trash piles (Wright and Wright 1957:308).

Special Habitat Requirements: Sandy soils, open woodlands.

Age/Size at Sexual Maturity: Males 400 to 1,050 mm, females 450 to 1,200 mm (Wright and Wright 1957:309). 

Breeding Period: April to May.

Egg Deposition: June to July. Eggs laid in earth, under or in pulpy wood of decaying logs.

Clutch Size: 4 to 42 eggs (Edgren 1955), typically 25.

Incubation Period: 39 to 60 days (Anderson 1965:185).

Eggs Hatch: July to September, peak in August.

Home Range/Movement: After 5 months one individual in Maryland mixed habitat had moved $100 \mathrm{ft}$ (Stickel and Cope 1974).

Food Habits/Preferences: Toads preferred, but frogs, fish, salamanders, insects and worms are taken; rarely small birds and mammals and occasionally other snakes (Edgren 1955). Amphibians and reptiles comprised $80 \%$ of the food items in 10 specimens in Virginia (Uhler et al. 1939).

Comments: Diurnal. Particularly vulnerable to heavy herbicide and pesticide use. Defense behavior includes feigning death, mock striking and head rearing, and "hood" display.

Selected References: Edgren 1955, Smith 1956, Wright and Wright 1957, McCoy and Bianculli 1966. 



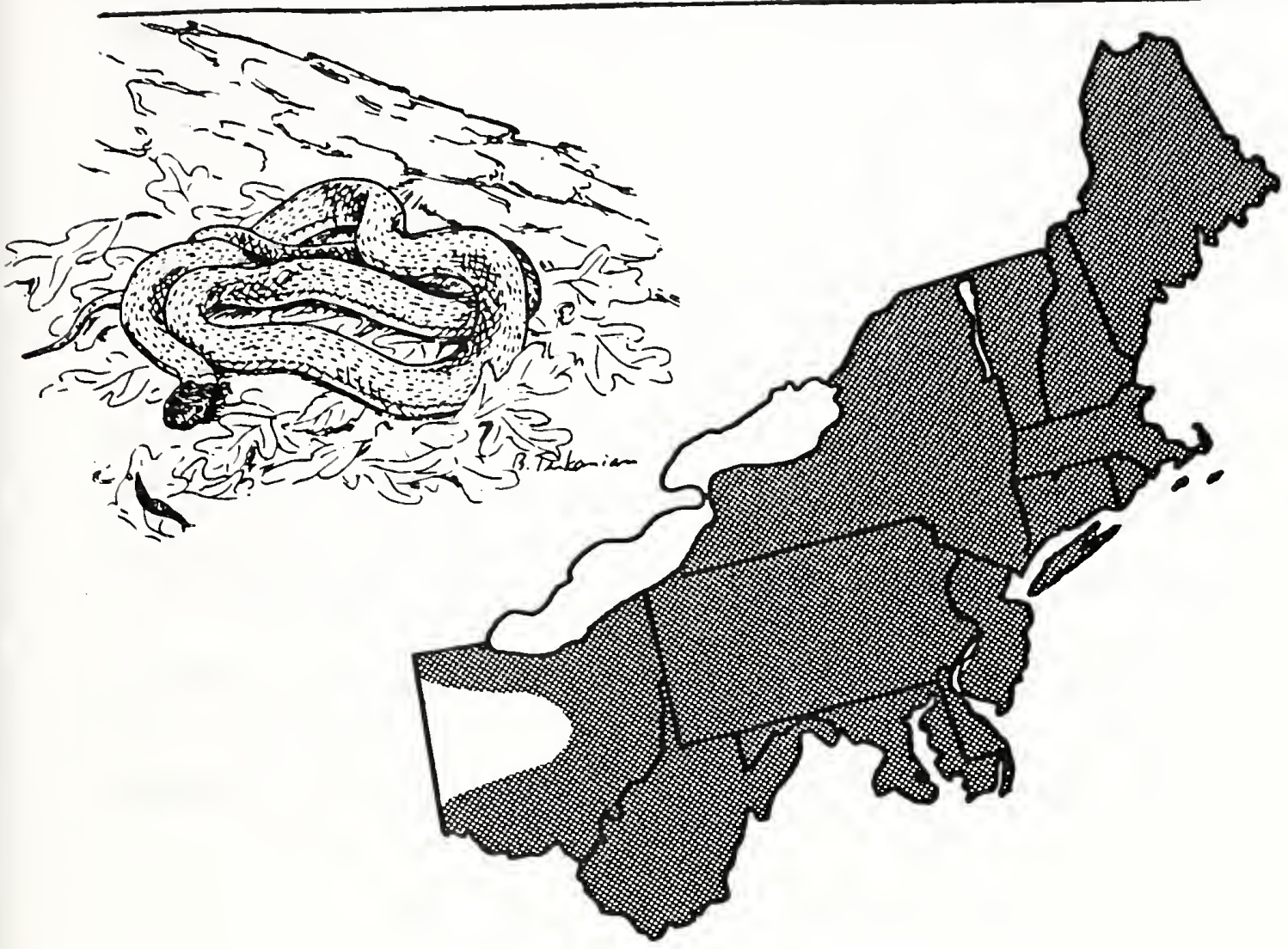

Range: Nova Scotia, s. Ontario to Wisconsin. Eastern and s. Ohio to s.e. Illinois, n.e. Alabama and north through c. Virginia to New England.

Relative Abundance in the Northeast: Common.

Habitat in the Northeast: Secretive, found under cover especially in moist shady woodlands with abundant hiding cover: stony woodland pastures, rocks, stone walls, old woodland junk piles, logs, debris, loose bark of logs and stumps, and boards are all used as cover. Hibernates from September to April or May. One individual found in a woodchuck den (Grizzel 1949).

Special Habitat Requirements: Mesic areas with abundant cover.

Age/Size at Sexual Maturity: Males at 13 to 14 months (Fitch 1960b), males 220 to $500 \mathrm{~mm}$, females 220 to $550 \mathrm{~mm}$ (Wright and Wright $1957: 187)$. 

Breeding Period: Soon after emerging from hibernation.

Egg Deposition: Late June to early July. Eggs laid in rotted logs, under logs or stones. Several females may use the same nest.

Clutch Size: 1 to 10 eggs, typically 3 or 4 (Blanchard 1937b).

Incubation Period: 4 to 6 weeks (Minton 1944). Average of 56 days in laboratory conditions (Blanchard 1930 cited in Wright and Wright 1957:188).

Eggs Hatch: Late August through September.

Home Range/Movement: Undocumented.

Food Habits/Preferences: Toads, frogs, salamanders, earthworms, lizards, sma 11 snakes, insects, grubs.

Comments: Nocturnal. Degree of fossorial tendency varies with temperature preference (Elick et a 1. 1979).

Selected References: Schmidt and Davis 1941, Wright and Wright 1957. 



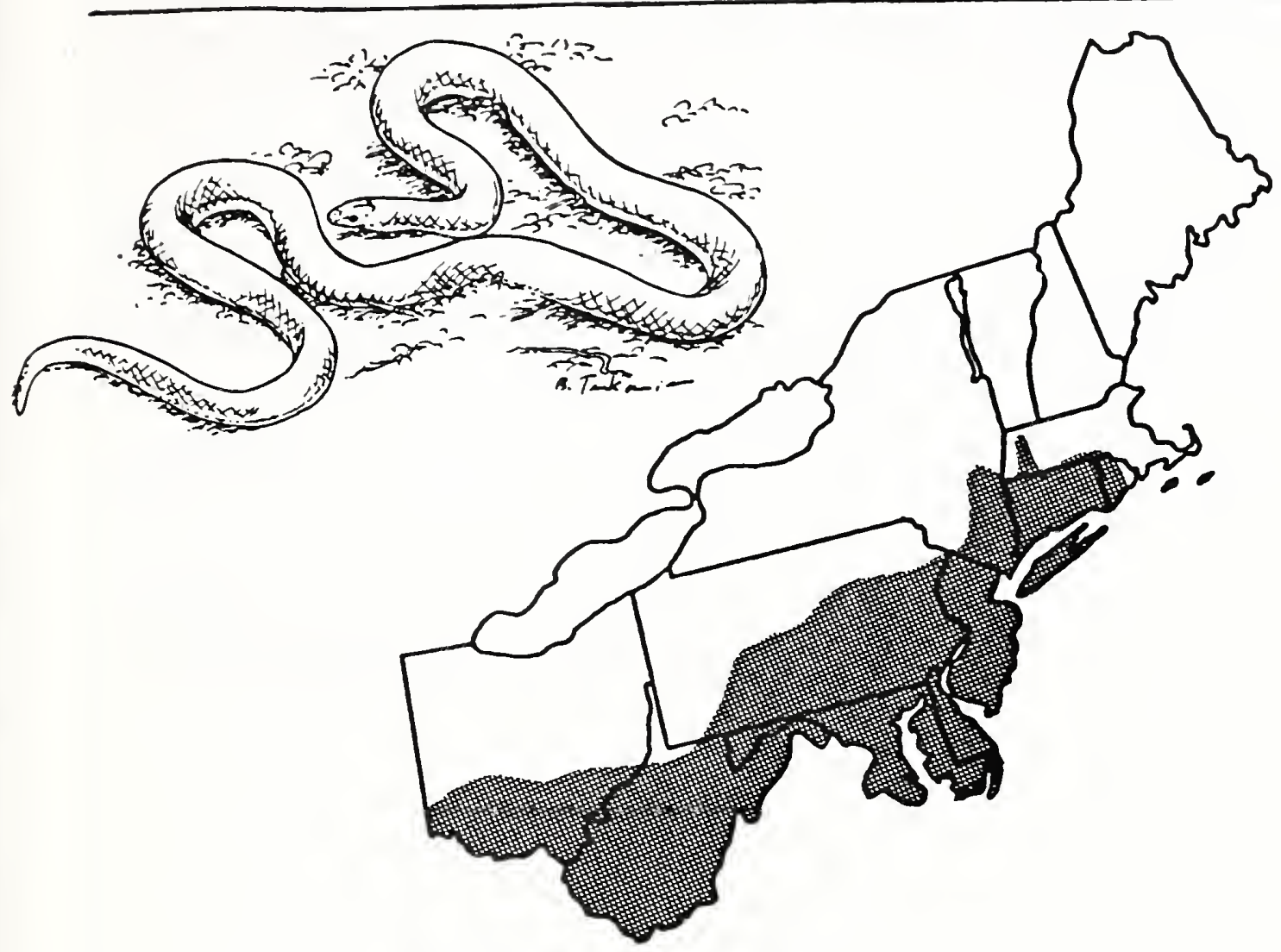

Range: Southcentral Massachusetts, s.e. New York through c. Pennsylvania to s. Ohio. South to c. Alabama, n. Georgia and South Carolina.

Relative Abundance in the Northeast: Locally abundant.

Habitat in the Northeast: Dry to moist forests, often near streams; in the loose soil of gardens or weedy pastures. Sandy areas favored (M. Klemens, pers. commun.). Found in dry oak/pitch pine areas in Springfield, Massachusetts (T. Tyning, pers. commun.) and under loose bark slabs, logs, stones, leaves, other debris. Fossorial; has extended periods of inactivity. Hibernates in rotting wood, underground, or in burrows of other animals. Remains underground until May except for warm sunny days.

Special Habitat Requirements: Loose soils for burrowing or covering objects.

Age/Size at Sexual Maturity: Undocumented.

Breeding Period: Probably spring to early summer (McCauley 1945:97). 

Egg Deposition: Late June to early July. Eggs probably laid in depressions under boulders or in hollow logs.

Clutch Size: 2 to 8 eggs (Wright and Wright 1957:106), typically 5 (McCauley 1945:55).

Eggs Hatch: August to September.

Home Range/Movement: About $1 / 4$ ac ( 0.1 ha) in Kentucky (Barbour 1971:240). Average for 10 individuals in a forested mountainous area of Kentucky was $253 \mathrm{~m}^{2}$ (Barbour et a1. 1969a).

Food Habits/Preferences: Earthworms, soft-bodied insects and their larvae, grubs or slugs.

Comments: Nocturnal and secretive.

Selected References: Schmidt and Davis 1941, Wright and Wright 1957, Barbour, Harvey and Hardin 1969a. 


Breeding Period: May to early June.

Egg Deposition: June to early July. Laid in rotting wood, stumps, decaying vegetable matter, loose soil.

Clutch Size: 7 to 31 eggs, typically 16 to 17 , clutch size proportional to size of female (Fitch 1963:420).

Incubation Period: 43 to 73 days in captivity (Fitch 1963:423).

Eggs Hatch: Late August to September.

Home Range/Movement: Very territorial; appears to have definite home range (Smith 1956:239). Average distance of $903 \mathrm{ft}(275.2 \mathrm{~m})$ in mixed Maryland habitat for 3 individuals after 2 years (Stickel and Cope 1947). Requires large tracts of mixed old fields and woodlands (M. Klemens, pers. commun.).

Food Habits/Preferences: Varied diet includes small mammals 25\%, insects, frogs, toads, small birds, bird's eggs, snakes $25 \%$ and 1 izards (Uhier et al. 1939). Small mammals and insects $50 \%$ of diet (Surface 1906).

Comments: Diurnal.

Selected References: Fitch 1963, Wilson 1978. 



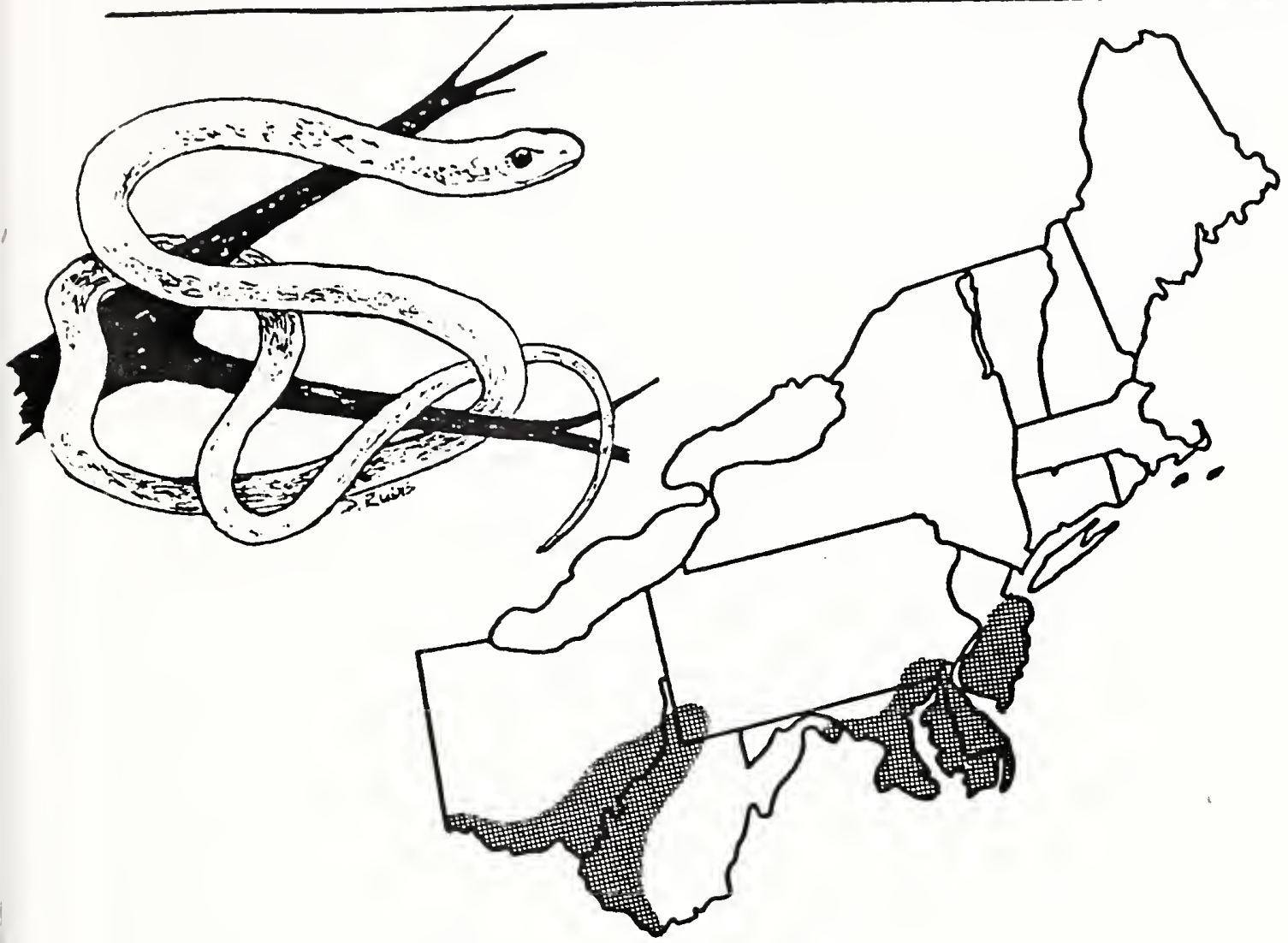

Range: Central New Jersey west to Kansas, south to the Florida Keys and Texas to Tampico, Mexico. Absent from the Appalachians of the Virginias.

Relative Abundance in the Northeast: Unknown.

Habitat in the Northeast: Arboreal, found in dense vegetation of stream or lake margins. Often enters shallow water. A forest edge species. Deciduous and coniferous forests, fields, marshes, back roads. Moist grassy meadows and fields in Virginia, often found under stones and logs (Martof et al. 1980:225). Sea level to 5,000 ft $(1,500 \mathrm{~m})$ (Behler and King 1979:640).

Special Habitat Requirements: Cover to provide arboreal escape.

Age/Size at Sexual Maturity: 1 to 2 years.

Breeding Period: Spring and fall. Breeding may be in arboreal situations. 

Egg Deposition: June to August.

Clutch Size: 3 to 14.

Incubation Period: 5 to 12 weeks.

Eggs Hatch: Early fall in Virginia (Martof et al. 1980:225).

Home Range/Movement: Unreported.

Food Habits/Preferences: Crickets, grasshoppers, larvae of moths and butterflies, slugs, millipedes, spiders and small salamanders. Forages amid vines or shrubs, under stones, logs.

Selected References: Minton 1972. 



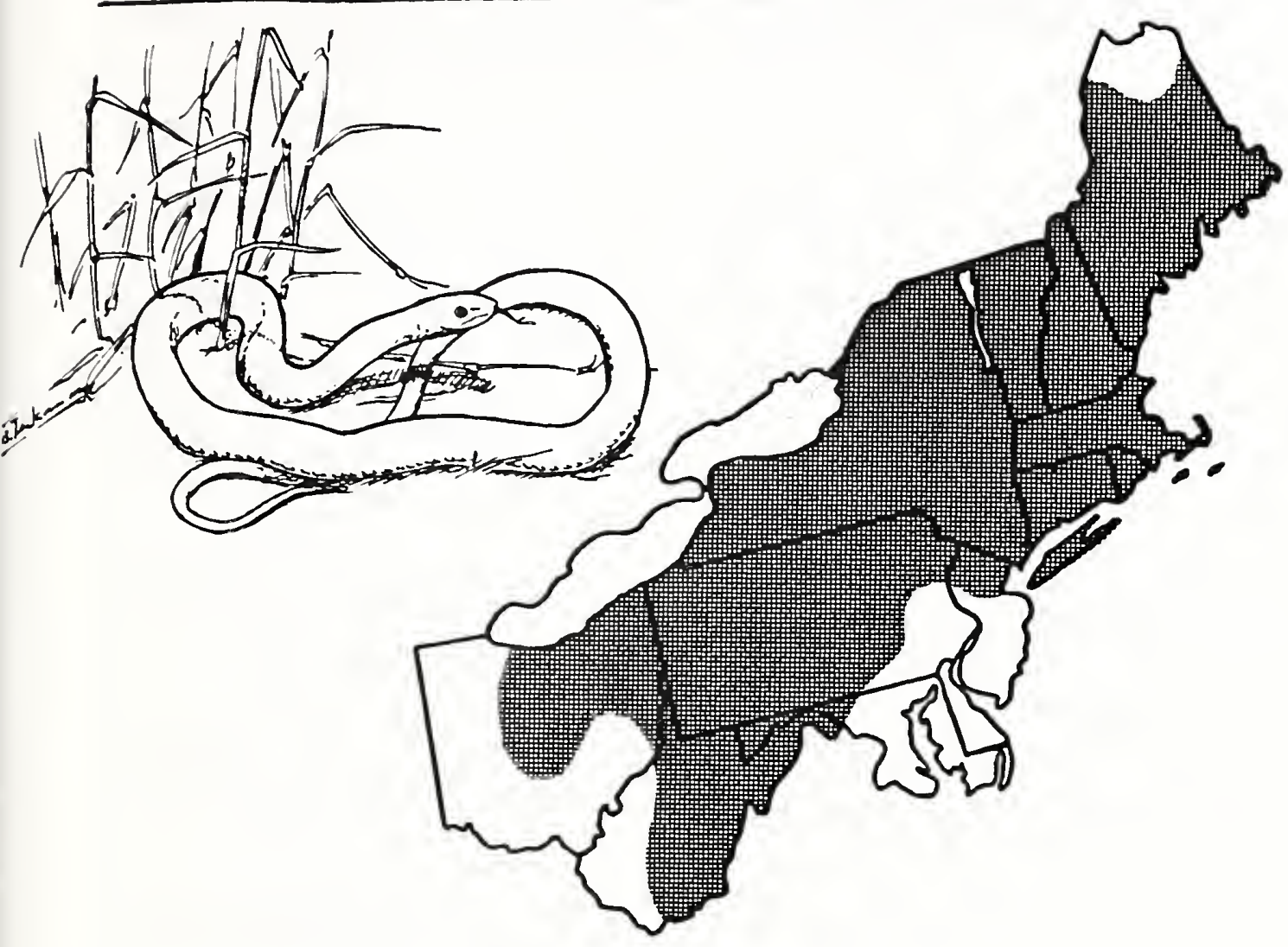

Range: Nova Scotia, s. Ontario, into c. Minnesota to s. Wisconsin, Michigan, n.e. Ohio to the Appalachians of Virginia and West $V$ irginia and north from $c$. New Jersey throughout New England with the possible exception of $n$. Maine.

Relative Abundance in the Northeast: Common, but currently declining in s. New England, New Jersey and Michigan.

Habitat in the Northeast: Upland areas, grassy fields, mountain meadows;

high altitude areas with grassy, open spots. Also found in open aspen stands, sphagnum bogs, marshes, in vines and brambles, and hardwood stands. Abandoned farmland dominated by successional vegetation and debris (man-made) on Long Island, New York (Schlauch 1975).

Special Habitat Requirements: Upland grassy openings.

Age/Size at Sexual Maturity: Probably second year (Seibert and Hagen 1947). 

Breeding Period: Late August in Ontario (Smith 1956:236). Spring and late summer (Behler and King 1979:640).

Egg Deposition: Late July to August.

Clutch Size: 3 to 12 eggs (Wright and Wright 1957:558), typically 7 (Blanchard 1933). Nest sites may be used by several females.

Incubation Period: Varies from 4 to 23 days (BTanchard 1933).

Eggs Hatch: August to early September.

Home Range/Movement: Less than 30 yd $(27.4 \mathrm{~m})$ for 10 of 12 individuals studied in an uncultivated field in Illinois (Seibert and Hagen 1947).

Food Habits/Preferences: Insects comprise $73 \%$ of prey $i$ tems, also spiders snails (Surface 1906). Salamanders, millipedes, centipedes, particularly caterpiliars, orthopterans, ants, flies (Uhler et a1. 1939).

Comments: Hibernates early fall to April or May. Population decline may be related to insecticide spraying and loss of open fields and pasture.

Selected References: Schmidt and Davis 1941, Seibert and Hagen 1947, Wright and Wright 1957. 



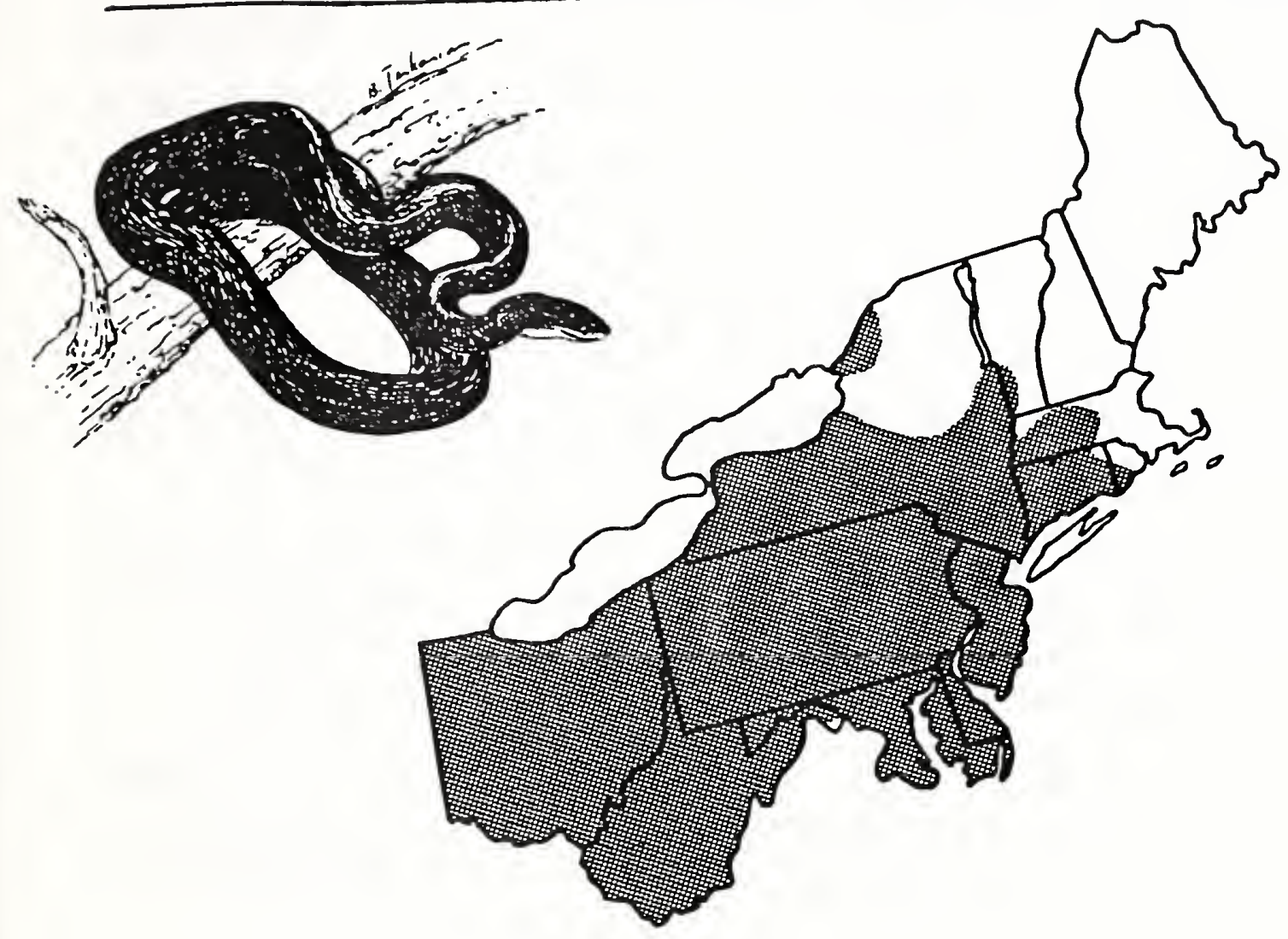

Range: Southwestern New England west through s. New York to s.c. Illinois, and the Mississippi River area in Wisconsin, south to Oklahoma, c. Louisiana and Georgia. Range may be extending northward in the Connecticut River Valley (T. Tyning, pers. commun.).

Relative Abundance in the Northeast: Common.

Habitat in the Northeast: Variety of habitats including woodlands, thickets, field edges, farmlands, rocky hillsides and mountaintops, river bottoms, old barns. Readily climbs trees. Found in dry oak and oak-hickory woods, and mesic bottomland forests, may occur in very dense woods (Wright and Wright 1957:232). In Connecticut found in gorges and some coastal areas (M. Klemens, pers. comun.).

Hibernates late November to April, may use talus slopes, cisterns or unused wells. Often found in groups with copperheads and rattlesnakes where these snakes occur.

Age/Size at Sexual Maturity: Males 1,095 to 1,835 mm, females 715 to $1,800 \mathrm{~mm}$ (Wright and Wright 1957:233). 

Breeding Period: May to June.

Gestation Period: 8 to 12 weeks (01iver 1955:243).

Egg Deposition: July to August. Laid in loose soil, decaying wood, manure piles, sawdust piles.

Clutch Size: 6 to 24 eggs, typically 14 .

Eggs Hatch: Late August to early October.

Home Range/Movement: Average of at least $600 \mathrm{~m}$ in diameter for males, and at least $500 \mathrm{~m}$ for females in woods and fields in Maryland (Stickel et al. 1980).

Food Habits/Preferences: Small mammals comprise $60 \%$ of prey items particularly rodents, small birds and their eggs $(30 \%)$, also amphibians, insects, spiders (Uhler et al. 1939). Young opossums, weasels, owls, and sparrow hawks have been captured as food (Minton 1972:273). Prey is killed by constriction.

Comments: Diurnal and arboreal.

Selected References: Schmidt and Davis 1941, Smith 1956, Wright and Wright 1957, Anderson 1965, Stickel et a1. 1980. 



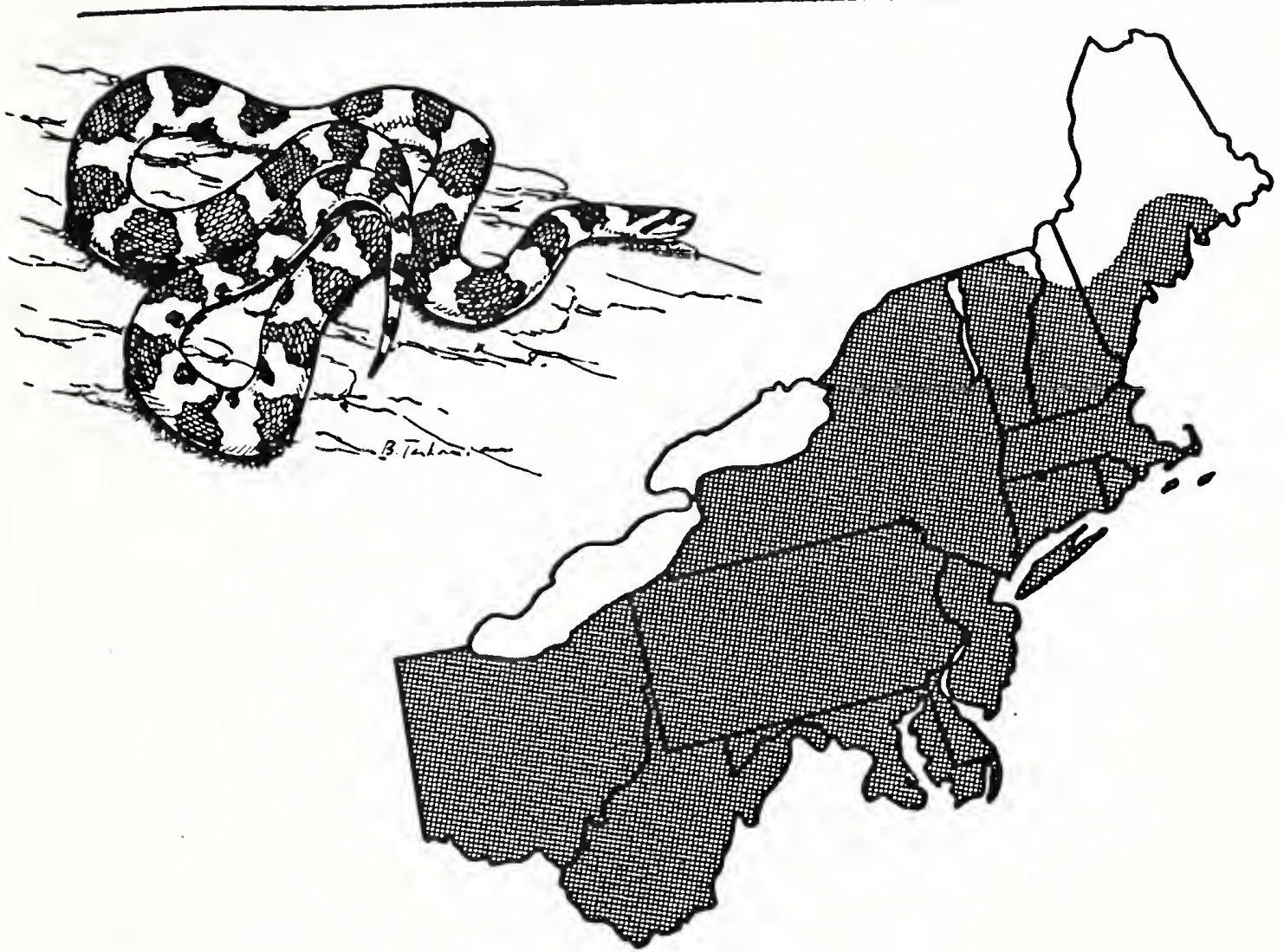

Range: Southeastern Maine and s. Ontario to c. Minnesota, south to Tennessee and w. North Carolina and throughout the Northeast. Intergrades with the scarlet king snake in the southwestern and southeastern portion of its range.

Relative Abundance in the Northeast: Common.

Habitat in the Northeast: Various habitats, usually with brushy or woody cover, and found from sea level to mountain elevations. Usually found under cover. Farmlands, woods, outbuildings, meadows, river bottoms, bogs, rocky hillsides, rodent runways (M. Klemens, pers. commun.). Found under logs, stones, boards, well covers, stones in creek bottoms (M. Stewart, pers. commun.) or other cover during the day. In pine forests, second-growth pine, bog woods, hardwoods, aspen stands. Hibernates from October or November to April.

Special Habitat Requirements: Suitable cover or loose soil for egg laying. Age/Size at Sexual Maturity: Third or fourth year (Fitch and Fleet 1970), males to 1,115 mm, females 404 to $966 \mathrm{~mm}$ (Wright and Wright 1957: 371 ). 

Breeding Period: June (Wright and Wright 1957:371).

Egg Deposition: Mid-June to July, in piles of soil, sawdust or manure, or under other cover, often in a communal nest site.

Clutch Size: 6 to 24 eggs, typically 13.

Incubation Period: 6 to 8 weeks (Wright and Wright 1957:371).

Eggs Hatch: Late August to October.

Home Range/Movement: About 50 ac (20.25 ha) for L. triangulum sypspiza, movements of 250 to $1,300 \mathrm{ft}(76.2$ to $396.2 \mathrm{~m})$ in open woodland in n.e. Kansas (Fitch and Fleet 1970). Seasonal movements probable from dryer hibernation sites to moist bottomlands for the summer (Breckenridge 1958 cited in Williams 1978:79).

Food Habits/Preferences: Mice, other small mammals, other snakes, lizards, birds and their eggs, slugs. Mice comprised $72 \%$ of the volume of stomach contents of $42 \mathrm{milk}$ snakes in Pennsylvania (Surface 1908). Forages for food at night.

Comments: Typically nocturnal. Numbers may be declining as abandoned fields revert to forests (T. Tyning, pers. commun.).

Selected References:: Schmidt and Davis 1941, Wright and Wright 1957, Fitch and Fleet 1970. 



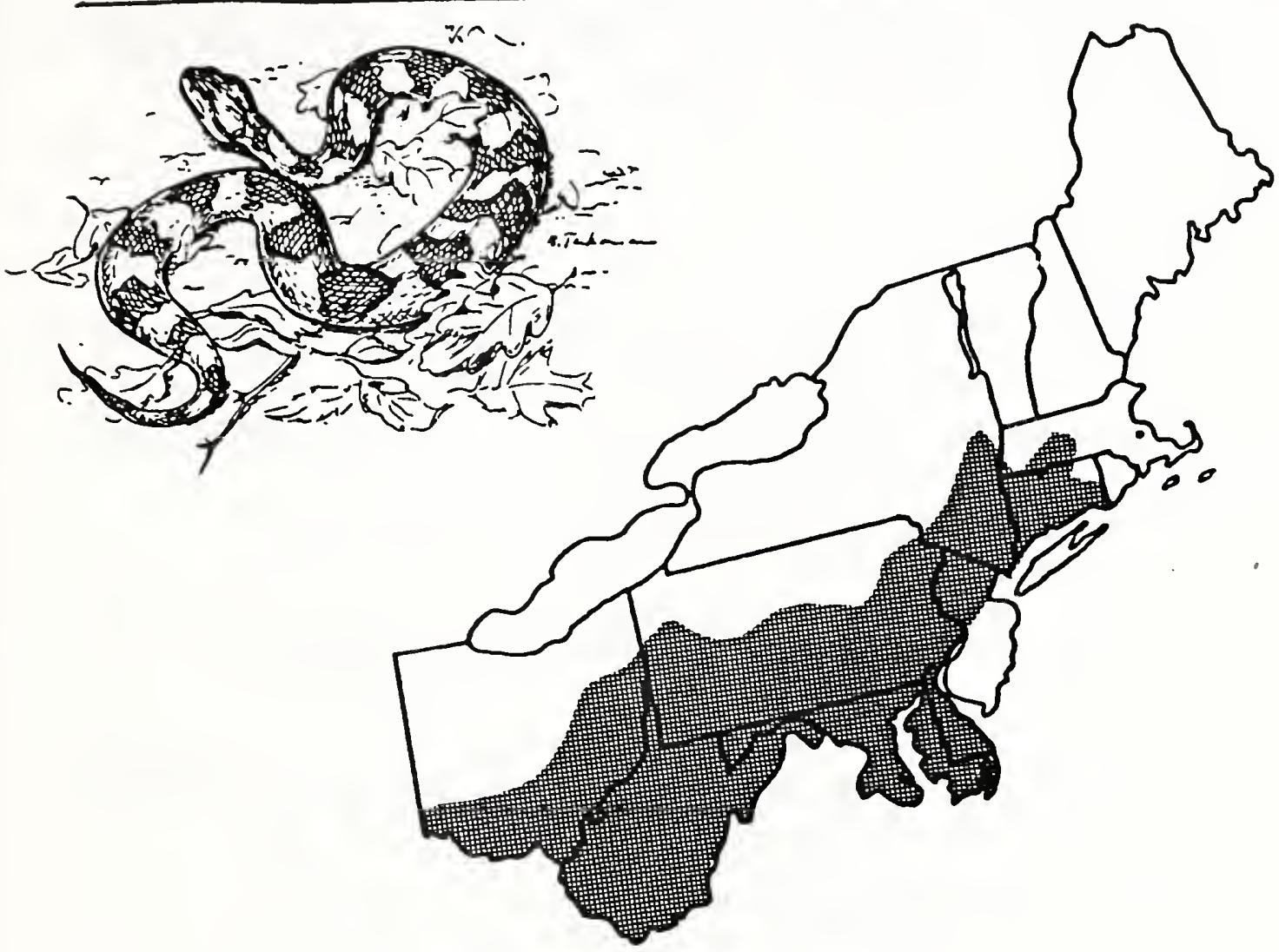

Range: Southwestern New England to S.w. Illinois, south to c. Georgia and through c. North Carolina.

Relative Abundance in the Northeast: Uncommon to rare.

Habitat in the Northeast: Usually associated with deciduous forests. Occupies varied habitats from swamps to mountain tops. Prefers areas with damp leaf litter (Fitch 1960a:116). Exposed mountainous, rocky hillsides, talus slopes, basalt ridges, ledges, open woods. Found in habitats with large rocks, rotting wood and sawdust piles. During summer months may be found near swamps, ponds, or streams. Largely outside of white pine-northern hardwood, and beech-maple associations (Fitch 1960a:123).

Special Habitat Requirements: Rocky hillsides, talus slopes.

Age/Size at Sexual Maturity: Males during their second summer, females at three years (Fitch 1960a:272). 

Breeding Period: April to May, peak in late May. Sperm may rema in viable in the female for more than a year after copulation (Allen 1955). Gestation period of 105 to 110 days (Fitch 1960a:116).

Young Born: August to September, typically September in the Northeast. Viviparous.

No. Young: 1 to 17 young, typically 5 to 6 (Wright and Wright 1957:913). Litters produced in alternate years.

Home Range/Movement: In mixed habitat of woodlands, ledges and grassland in Kansas. Fitch (1960a:147-149) recorded $24.4 \mathrm{ac}$ (9.7 ha), for males and $8.5 \mathrm{ac}(3.4 \mathrm{ha})$ for females. Seasonal movements occur between hibernaculum and lowland areas.

Food Habits/Preferences: Mice, other small rodents, insects, small birds, salamanders, lizards, small snakes, frogs, toads. Food obtained by ambush.

Comments: Nocturnal during summer months, diurnal in spring and fall. Has survived eradication in some areas due to (cryptic) coloration and retiring habits. Uusally gregarious. During hibernation from October to April, sometimes found with other species of snakes including rattlesnakes. Mutually exclusive in Connecticut (Peterson 1970). Den sites are reused each year--a major limiting factor.

Selected References: Schmidt and Davis 1941, Smith 1956, Wright and Wright 1957, Fitch 1960, Anderson 1965. 



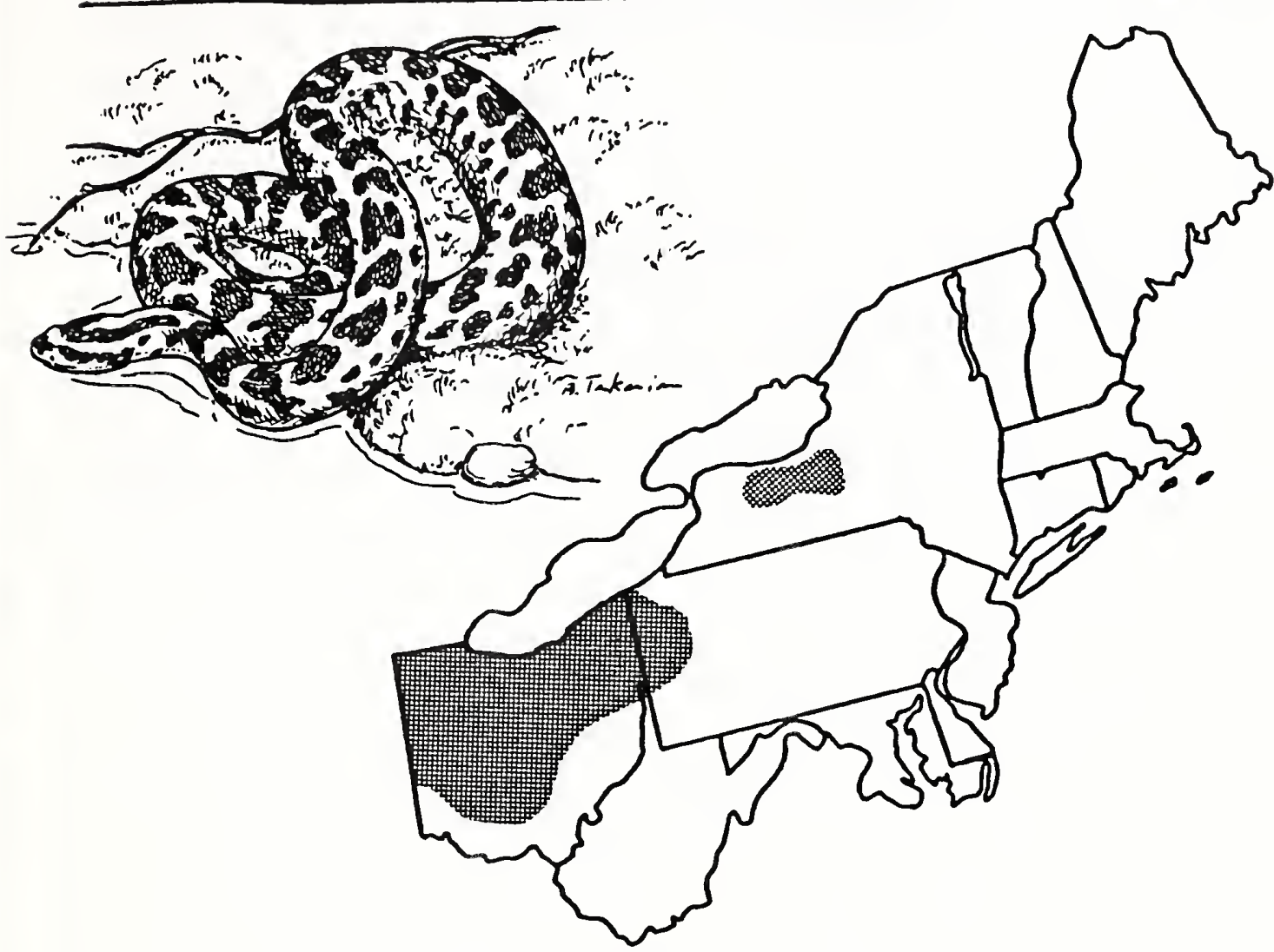

Range: Central New York, s. Ontario, s. Wisconsin to e. Iowa, Kansas, and $n$. Missouri to $s$. Indiana, Illinois and Ohio, extending into w. Pennsylvania.

Relative Abundance in the Northeast: Threatened (Federal List).

Habitat in the Northeast: Swampy areas, marshes, bogs and farmland, poorly drained areas, inundated bottomland. In summer months may move to drier areas. Hides under boards, tar paper, and other debris, in underground cavities or shocks of grain. Hibernates from November to April in wet areas.

Age/Size at Sexual Maturity: During third year (Wright 1941, Minton 1972:318).

Breeding Period: Late Apri1, May or June. Gestation period of 15 to 16 weeks (Wright 1941). 

Young Born: August to September. Viviparous.

No. Young: 2 to 14 snakes, typically 7 to 9 (Klauber 1972:733).

Home Range/Movement: Undocumented.

Food Habits/Preferences: Small terrestrial mammals, particularly mice; also frogs, small snakes, lizards, small birds. Warm-blooded prey comprised $95 \%$ of the food items of 323 individuals in Wisconsin; all food items were rodents except for 5 snakes and 1 blackbird (Keenlyne and Beer 1973).

Selected References: Wright 1941, Smith 1956, Wright and Wright 1957. 



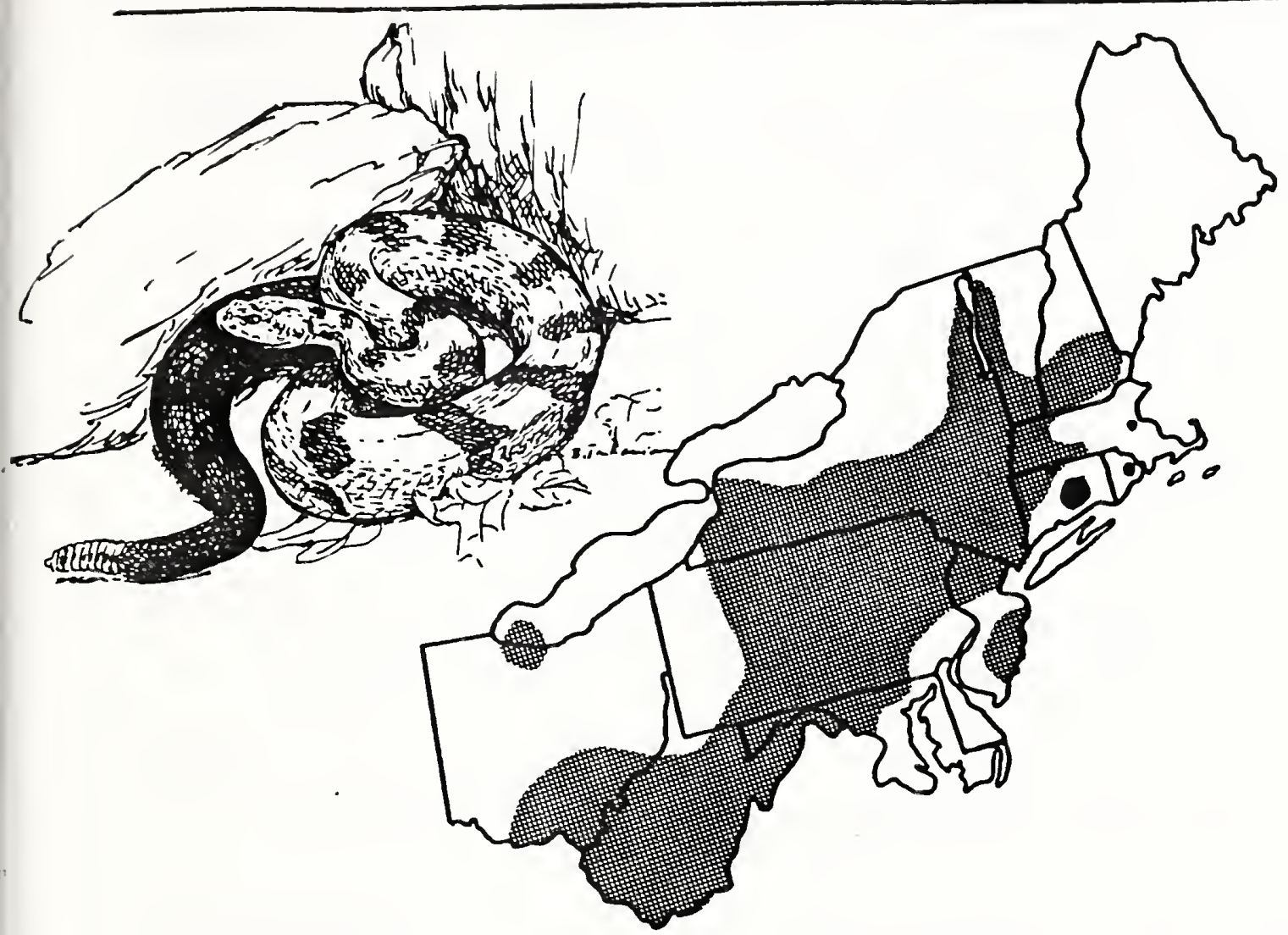

Range: Southern New Hampshire, the Lake Champlain area to s.w. New York, west along the Ohio River Valley and north to the Mississippi River in Wisconsin. Extending to n. Texas, s. Illinois, n. Georgia and through the Appalachians to New Jersey.

Relative Abundance in the Northeast: Uncommon to rare.

Habitat in the Northeast: Timbered areas with rocky outcroppings, dry ridges and second growth deciduous or coniferous forests with high rodent populations. Usually southern exposures. Sometimes in swamps, quarries, old stone walls, abandoned buildings. Often found near streams in late summer. Most commonly in areas unfrequented by man, few isolated sites in existence.

Hibernates from September to April in large numbers in rocky crevices usually overgrown with brush. Found with copperheads and other snakes, due to paucity of hibernacula (T. Tyning, pers. commun.).

Special Habitat Requirements: Rock outcroppings on forested hillsides. 

Age/Size at Sexual Maturity: Probably 3-1/2 to 4 years (Klauber 1972:335). Breeding Period: April to May, Missouri (Anderson 1965:289), fall in Wisconsin (Messeling 1953) and Connecticut (T. Tyning, pers. commun.). Gestation period probably about 5-1/2 to 6 months.

Young Born: Late August to September, probably biennial cycles (Klauber 1972:691). Viviparous.

No. Young: 5 to 17 young, typically 7 to 10 (Klauber 1972:733).

Home Range/Movement: Females return to hibernation dens to give birth to young. Hibernation dens may be used year after year. Home ranges and favored refuges probably exist, but few investigations have been conducted (K1auber 1972:606-607).

Food Habits/Preferences: Prefers warm-blooded prey. Small mammals comprise $87 \%$ of prey taken (Uhler et al. 1939), particularly mice, but includes rabbits, shrews, chipmunks, squirrels, bats, songbirds and other snakes. Forages at night.

Comments: Extirpated from much of its former range by man; over-collection and habitat disturbance are serious threats to Crotalus horridus in the Northeast. Danger to humans is grossly exaggerated.

Selected References: Wright and Wright 1957, Anderson 1965, Klauber 1972. 




\section{LITERATURE CITED}

Adler, K. K.

1961. Egg-laying in the spotted turtle, Clemms gutta (Schneider). Ohio J. Sci. 61(3):180-182.

Alexander, M. M.

1943. Food habits of the snapping turtle in Connecticut. J. Wild1. Manage. $7(3): 278-282$.

Allard, H. A.

1935. The natural history of the box turtle. Sci. Monthly $41: 325-338$.

Allen, J. A.

1868. Catalogue of the reptiles and batrachians found in the vicinity of Springfield, Massachusetts, with notices of all the other species known to inhabit the state. Proc. Boston Soc. Nat. Hist. 12:171-204, 248-250.

Allen, W. B.

1955. Some notes on reptiles. Herpetologica 11(4):228.

Anderson, J. D.

1967a. Ambystoma maculatum. Cat. Am. Amphib. Rept. 51.1-51.4.

1967b. Ambystoma opacum. Cat. Am. Amphib. Rept. 46.1-46.2.

Anderson, J. D., and P. J. Martino.

1966. The life history of Eurycea Z. Zongicauda associated with ponds. Am. Mid1. Nat. 75(2):257-279.

1967. Food habits of Eurycea 2. Zongicauda. Herpetologica 23(2): 105-108. 


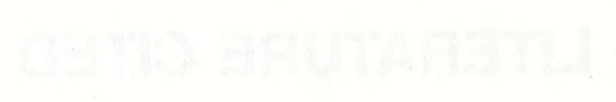


Anderson, $P$.

1965c. The reptiles of Missouri. Univ. Missouri Press, Columbia. $330 \mathrm{pp}$.

Ashton, R. E., Jr.

1975. A study of movement, home range, and winter behavior of

Desmognathus fuscus (Rafinesque). J. Herpetol. 9(1):85-91.

Ashton, R. E., and P. S. Ashton.

1978. Movements and winter behavior of Eurycea bislineata (Amphibia, Urodela, Plethodontidae). J. Herpetol. 12(3):295-298.

Asplund, K. K.

1963. Ecological factors in the distribution of Thamophis brachystoma (Cope). Herpetologica 19(2):128-132.

Babbitt, L. H.

1937. The amphibia of Connecticut. Hartford: State Geol. and Nat.

Hist. Surv. Bu11. No. 27:9-47.

Babcock, H. L.

1919. The turtles of New England. Memoirs of the Boston Soc. of

Nat. Hist. 8(3):325-431. (Reprinted 1971. Turtles of the northeastern

United States. Dover Pub1., Inc., New York. 105pp.)

Bal1, S. C.

1936. The distribution and behavior of the spadefoot toad in

Connecticut. Trans. Connecticut Acad. Arts and Sci. 32:351-379.

(Information obtained from Bragg 1965.)

Banasiak, C. F.

1974. Population structure and reproductive ecology of the redbacked salamander in DDT-treated forests of northern Maine. Unpub1. Ph.D. Thesis. Univ. Maine, Orono. 113pp. 

Barbour, R. W.

1971. Amphibians and reptiles of Kentucky. The Univ. Press of Kentucky, Lexington. 334pp.

Barbour, R. W., M. J. Harvey, and J. W. Hardin.

1969a. Home range, movement, and activity of the eastern worm snake, Carphophis a. comoenus. Ecology 50(3):470-476.

Barbour, R. W., J. W. Hardin, J. P. Schafer, and M. J. Harvey.

1969b. Home range, movement, and activity of the dusky salamander, Desmognathus fuscus. Copeia 1969(2):293-297.

Barthalmus, G. T., and E. D. Bellis.

1969. Homing in the northern dusky salamander, Desmognathus $f$. fuscus (Rafinesque). Copeia 1969(1):148-153.

Barton, A. J.

1957. Our knowledge of the bog turtle, CZemmys muhlenbergi, further augmented. M.S. Thesis, Univ. Pittsburgh, Penn. 75pp. (Information obtained from Ernst 1977.)

Barton, A. J., and J. W. Price.

1955. Our knowledge of the bog turtle, clemms muhlenbergi, surveyed and augmented. Copeia 1955(3):159-165.

Behler, J. L., and F. W. King.

1979. The Audubon Society field guide to North American reptiles and amphibians. Alfred A. Knopf, Inc., New York. 718pp.

Bellis, E. D.

1961. Growth of the wood frog, Rana syzvatica. Copeia 1961(1):74-77.

1965. Home range and movements of the wood frog in a northern bog. Ecology 46(1\&2):90-98.

1968. Summer movement of red-spotted newts in a small pond. $J$. Herpetol. 1(1-4):86-91. 

Bennett, D. H., J. W. Gibbons, and J. C. Franson.

1970. Terrestrial activity in aquatic turtles. Ecology 51:738-740.

Bishop, S. C.

1925. The life of the red salamander. Nat. Hist. 25(4):385-389.

1941. The salamanders of New York. New York State Mus. Bull. No. $324: 1-365$.

1943. Handbook of salamanders. Comstock Publ. Co., I thaca, New York. 555pp.

1947. Handbook of salamanders. The salamanders of the United States, of Canada, and Lower California. Comstock Publ. Co., Inc., I thaca, New York. 555pp.

Blanchard, F. N.

1923. The life history of the four-toed salamander. Am. Nat. $57: 262-268$.

1930. Further studies on the eggs and young of the eastern ringneck snake, Diadophis punctatus edwardsii. Bull. Antivenin Inst. Am. 4:4-10. (Information obtained from Wright and Wright 1957.)

1933. Eggs and young of the smooth green snake, Liopeltis vermalis (Harlan). Pap. Mich. Acad. Sci. 17:493-508.

1934. The relation of the four-toed salamander to her nest.

Copeia 1934(3):137-138.

1937a. Data on the natural history of the red-bellied snake, Storeria occipito-maculata (Storer), in northern Michigan. Copeia 1937(3):151-162.

1937b. Eggs and natural nests of the eastern ring-neck snake, Diadophis punctatus edwardsii. Pap. Mich. Acad. Sci. 22:521-532.

Blanchard, F. N., and F. C. Blanchard.

1942. Mating of the garter snake, Thamophis s. sirtalis (Linnaeus). Pap. Mich. Acad. Sci., Arts and Letters 27:215-234. 

Bleakney, J. S.

1952. The amphibians and reptiles of Nova Scotia. Can. Field-Nat. $66(5): 125-129$.

1957. The egg-laying habits of the salamander, Ambystoma jeffersonianum. Copeia 1957(2):141-142.

1959. Thamnophis s. sirtalis (Linnaeus) in eastern Canada, redescription of T. S. palzidula (Allen). Copeia 1959(1):52-56.

Bothner, R. C.

1963. A hibernaculum of the short-headed garter snake, Thomnophis brachystoma (Cope). Copeia 1963(3):572-573.

1976. Tharmophis brachystoma (Cope). Cat. Am. Amphib. Rept. $190.1-190.2$.

Bragg, A. N.

1965. Gnomes of the night, the spadefoot toads. Univ. Penn. Press, Philadelphia. $127 \mathrm{pp}$.

Brandon, R. A.

1961. A comparison of the larvae of five northeastern species of Ambystoma (Amphibia, Caudata). Copeia $1961(4): 377-383$.

1967. Gyrinophizus porphymiticus (Green). Cat. Am. Amphib. Rept. 33. 1-33.3.

Breckenridge, W. J.

1958. Reptiles and amphibians of Minnesota. 2nd ed. Univ. Minn. Press, Minneapolis. 202pp.

Breder, R. B.

1927. Turtle trailing: a new technique for studying the life habits of certain testudinata. Zoologica 9:231-243.

Brimley, C. S.

1939. The amphibians and reptiles of North Carolina. Carolina

Tips $2(1-7), 3(1-7)$. 

Brodie, E. D.

1968. Investigations on the skin toxin of the red-spotted newt,

Notophthalmus v. viridescens. Am. Midl. Nat. 80:276-280.

Brown, E. E.

1979. Stray food records from New York and Michigan snakes.

Am. Midl. Nat. 102(1):200-203.

Bruce, R. C.

1968. Life history studies of the salamanders of the genus

Pseudotriton (Caudata:Plethodontidae). Ph.D. Thesis, Duke Univ.

$x i i+222 p p$.

1969. Fecundity in primitive plethodontid salamanders. Evolution 23:50-54.

1972. Variation in the life cycle of the salamander Gypinophizus porphyriticus. Herpetologica 28(2):230-245.

1978. Reproductive biology of the salamander Pseudotriton mber

in the southern Blue Ridge Mountains. Copeia 1978(3):417-423.

1980. A model of the larval period of the spring salamander,

Gyrinophizus porphypiticus, based on size-frequency distributions.

Herpetologica 36(1):78-86.

Burger, J. W.

1935. Plethodon cinereus (Green) in eastern Pennsylvania and New Jersey. Am. Nat. 69:578-586.

Burkett, R. D.

1969. An ecological study of the cricket frog, Acris crepitans,

in northeastern Kansas. Ph.D. Thesis, Univ. Kansas. 127pp.

[From Diss. Abstr. 39(6B):2956-B, 1969.]

Burton, T. M.

1976. An analysis of the feeding ecology of the salamanders

(Amphibia, Urodela) of the Hubbard Brook Experimental Forest,

New Hampshire. J. Herpeto1. 10(3):187-204. 

Burton, T. M.

1977. Population estimates, feeding habits and nutrient and energy relationships of Notophthalmus $v$. viridescens, in Mirror Lake, New Hampshire. Copeia 1977(1):139-143.

Burton, T. M., and G. E. Likens.

1975. Salamander populations and biomass in Hubbard Brook Experimental Forest, New Hampshire. Copeia 1975:541-546.

Bury, R. B.

1979. Review of the ecology and conservation of the bog turtle, CZemys muhlenbergii. U.S. Fish and Wild1. Serv. Spec. Sci. Rep., Wi1d1. No. 219. 9pp.

Cagle, F. R.

1942. Herpetological fauna of Jackson and Union Counties, Illinois.

Aim. Mid1. Nat. 28(1):164-200. (Information obtained from Smith 1961.)

1944. Home range, homing behavior, and migration in turtles. Misc. Publ. Mus. Zool., Univ. Mich. No. 61:1-34.

1945. Notes on SceZoporus u. undulatus. Copeia 1945(2):122.

1950. The life history of the slider turtle, Pseuderms scripta troostii (Holbrook). Ecol. Monogr. 20:31-54.

Cahn, A. R.

1937. The turtles of Illinois. Illinois Biol. Monogr. 16(1-2):

1-218. (Information obtained from Conant 1938.)

Caldwel1, R. S.

1975. Observations on the winter activity of the red-backed salamander, Plethodon cinereus, in Indiana. Herpetologica $31(1): 21-22$. 

Carpenter, C. C.

1952a. Growth and maturity of three species of Thomnophis in

Michigan. Copeia 1952(4):237-243.

1952b. Comparative ecology of the common garter snake (Thamnophis

s. sirtalis), the ribbon snake (Thamophis s. sauritus), and

Butler's garter snake (Tharmophis butleri) in mixed populations.

Ecol. Monogr. 22(4):235-258.

Carr, A. F.

1952. Handbook of turtles of the United States, Canada, and

Baja California. Comstock Publ. Assoc., Ithaca, New York. 542pp.

Clarke, R. D.

1974. Activity and movement patterns in a population of Fowler's toad, Bufo woodhousei fowleri. Am. Midl. Nat. 92(2):257-274.

Cochran, D. M.

1961. Living amphibians of the world. Doubleday \& Co., Inc.,

Garden City, New York. 199pp.

Collins, H. H., Jr.

1959. Complete field guide to American wildlife. Harper and Bros.

Pub1., New York. 683pp.

Collins, J. T., J. E. Huheey, J. L. Knight, and H. M. Smith.

1978. Standard common and current scientific names for North

American amphibians and reptiles. Soc. for the Study of Amphib. and Rept. 36pp.

Conant, R.

1938. The reptiles of Ohio. Am. Midl. Nat. 20(1):1-200.

1975. A field guide to reptiles and amphibians of eastern and central North America. 2nd ed., Houghton Mifflin Co., Boston. 429pp. 

Cooper, J. E.

1956. Aquatic hibernation of the red-backed salamander.

Herpetologica 12(3):165-166.

1959. The turtle Pseudemys scripta feral in Maryland.

Herpetologica 15:44.

Craig, R. J., M. W. Klemens, and S. S. Craig.

1980. The northeastern range limit of the eastern mud turtle, Kinosternon s. subrubmom (Lacepede). J. Herpetol. 14(3):295-297.

Currie, W., and E. D. Bellis. -

1969. Home range and movements of the bullfrog, Rona catesbeiana (Shaw), in an Ontario Pond. Copeia 1969(4):688-692.

Danstedt, R. T., Jr.

1975. Local geographic variation in demographic parameters and body size of Desmognathus fuscus (Amphibia, Plethodontidae). Ecology 56(5):1054-1067.

Davidson, J. A.

1956. Notes on the food habits of the slimy salamander, Plethodon g. glutinosus. Herpetologica 12(2):129-131.

Delzell, D. E.

1958. Spatial movement and growth of Hyla cmucifer. Ph.D. Diss., Univ. Mich. 26pp. [From Diss. Abstr. 19(6):1478, 1958.]

Dickerson, M. C.

1969. The frog book. Dover Publ., Inc., New York. 253pp. (Originally printed 1906. Doubleday, Page and Co.)

Ditmars, R. L.

1907. The reptile book. Doubleday, Page and Co., New York. 472pp. 

Dodd, C. K., Jr.

1979. Amphibians and reptiles, the declining species. Water Spectrum 10(1):24-32.

Dole, J.W.

1965. Summer movements of adult leopard frogs, Rana pipiens

(Schreber), in northern Michigan. Ecology 46(3):236-255.

1968. Homing in leopard frogs, Rana pipiens. Ecology 49(3):386-399.

Drake, C. J.

1914. The food of Rana pipiens (Schreber). Ohio Nat. 14(5):257-269.

Driver, E. C.

1936. Observations on Scaphiopus holbrooki (Harlan). Copeia 1936(1):67-69.

Dundee, H. A.

1971. Cryptobranchus aZleganiensis. Cat. Am. Amphib. Rept. 101.1-101.4.

Dunn, E. R.

1926. The salamanders of the family Plethodontidae. Smith Coll. 50th Anniv. Publ., Northampton, Mass. 441pp.

Edgren, R. A.

1955. The natural history of the hog-nosed snakes, genus Heterodon:

a review. Herpetologica 11(2):105-117.

1960. Ovulation time in the musk turtle, Stemotherus odoratus (Latreille). Nat. Hist. Misc. 152:1-3.

Elick, G. E., J. A. Sealander, and R. J. Beumer.

1979. Temperature preferenda, body temperature tolerances, and habitat selection of small Colubrid snakes. Trans. Missouri Acad. Sci. 13:21-31. 

Emlen, S. T.

1968. Territoriality in the bullfrog, Rana catesbeicana.

Copeia 1968(2):240-243.

Ernst, C. H.

1968a. Homing ability in the spotted turtle, Clemmys guttata

(Schneider). Herpetologica 24:77-78.

1968b. A turtle's territory. Int. Turtle and Tortoise Soc. J. $2(6): 9,34$.

1970. Home range of the spotted turtle. Copeia 1970(2):391-392.

1971. Chrysemys picta (Schneider). Cat. Am. Amphib. Rept.

$106.1-106.4$.

1972a. Clemmys guttata (Schneider). Cat. Am. Amphib. Rept.

$124.1-124.2$.

1972b. Clemmys insculpta (LeConte). Cat. Am. Amphib. Rept. $125.1-125.2$.

1977. Biological notes on the bog turtle, Clemms mihlenbergii. Herpetologica $33(2): 241-246$.

Ernst, C. H., and R. W. Barbour.

1972. Turtles of the United States. Univ. Press of Kentucky, Lexington. $347 \mathrm{pp}$.

Ernst, C. H., and R. B. Bury.

1977. CZemons mihlenbergii (Schoepff). Cat. Am. Amphib. Rept. 204. $1-204.2$.

Evermann, B. W., and H. W. Clarke.

1916. The turtles and batrachians of the Lake Maxin Kuekee region.

Proc. Indiana Acad. Sci. 1916:472-518.

Ewing, H. E.

1943. Continued fertility in the female box turtles following mating. Copeia 1943(2):112-114. 

Farrell, R. F., and R. T. Zappalorti.

1979. The ecology and distribution of the wood turtie, clenoms insculpta (LeConte), New Jersey, Part I. [Preliminary report on a research contract between the New Jersey Dept. of Environ. Protection, Endangered and Nongame Species Proj., Nat. Audubon Soc. and Herpetological Assoc. No. 79.03. 17pp. (unpubl.).] 1980. An ecological study of the wood turtle, Clemmys insculpta (LeConte), (Reptilia, Testudines, Emydidae) in northern New Jersey, Part II. [Report to the New Jersey Dept. of Environ. Protection, Endangered and Nongame Species Proj., Herpetological Assoc. Rep. No. 80.02. 17pp. (unpubl.).]

Fellers, G. M.

1979. Mate selection in the gray treefrog, Hyla versicolor. Copeia 1979(2):286-290.

Finneran, L. C.

1948. Reptiles in Branford, Connecticut. Herpetologica 4:123-126.

Fitch, H. S.

1954. Life history and ecology of the five-lined skink, Eumeces fasciatus. Univ. Kansas Publ., Mus. Nat. Hist. 8(1):1-156. (Information obtained from Minton 1972.)

1960a. Autecology of the copperhead. Univ. Kansas Publ., Mus. Nat. Hist. 13(4):185-288.

1960b. Criteria for determining sex and breeding maturity in snakes. Herpetologica 16(1):49-51.

1963. Natural history of the racer Coluber constrictor. Univ.

Kansas Pub1., Mus. Nat. Hist. 15(8):351-468.

1965. An ecological study of the garter snake, Thoomophis sirtalis. Univ. Kansas Publ., Mus. Nat. Hist. 15:493-564.

Fitch, H. S., and B. Glading.

1974. A field study of a rattlesnake population. Calif. Fish and Game 33(2):103-123. 

Fitzpatrick, L. C.

1973. Energy allocation in the Allegheny Mountain salamander, Desmognathus ochrophaeus. Ecol. Monogr. 43:43-58.

Force, E. R.

1933. The age of attainment of sexual maturity of the leopard frog Rana pipiens (Schreber) in northern Michigan. Copeia 1933(3): 128-131.

Forester, D. C.

1977. Comments on the female reproductive cycle and philopatry by Desmognathus ochrophaeus (Amphibia, Urodela, Plethodontidae). J. Herpetol. 11(3):311-316.

1979. Homing to the nest by female mountain dusky salamander. Desmognathus ochrophaeus, with comments on the sensory modalities essential to clutch recognition. Herpetologica $35(4): 330-335$. .

Fraker, M. A.

1970. Home range and homing in the watersnake, Natrix s. sipedon.

Copeia 1970(4):665-673.

Franz, R.

1964. The eggs of the long-tailed salamander from a Maryland cave. Herpetologica $20(3): 216$.

Gehlbach, F. R.

1967. Ambystoma tigrinum. Cat. Am. Amphib. Rept. 52.1-52.4.

Gibbons, J. W.

1968a. Reproductive potential, activity and cycles in the painted turtle, Chrysemys picta. Ecology 49(3):399-409.

1968b. Observations on the ecology and population dynamics of the Blanding's turtle, Emydoidea blandingi. Can. J. Zool. 46:288-290. 

Gi11, D. E.

1979. Density dependence and homing behavior in adult red-spotted newts, Notophthalmus viridescens (Rafinesque). Ecology 60(4): 800-813.

Gochfeld, M.

1975. The decline of the eastern garter snake, Thammophis s.

sirtalis, in a rural residential section of Westchester County, New York. Engelhardtia 6(3):23-24.

Gordon, D. M.

1980. An investigation of the ecology of the map turtle, Grapterrys geographica (LeSueur), in the northern part of its range. Can. J. Zool. 58(12):2210-2230.

Gordon, R. E.

1968. Terrestrial activity of the spotted salamander, Ambystoma macuzatiom. Copeia 1968(4):879-880.

Graham, T. E.

1971a. Growth rate of the red-bellied turtle, Chrysemys rubriventris at Plymouth, Massachusetts. Copeia 1971(2):353-356.

1971b. Eggs and hatchlings of the red-bellied turtle, Chrysemys mibriventris, from Plymouth, Massachusetts. J. Herpetol. 5(1-2): $59-60$.

1978a. Massachusetts frogs and toads. (Part II-conclusion). Mass. Wildl. 29(6):12-19.

1978b. The salamanders of Massachusetts. Mass. Wildr. 29(2):2-9, 15-16.

1980. Red-belly blues. Animals 113(1):17-21.

Graham, T. E., and T. S. Doyle.

1977. Growth and population characteristics of Blanding's turtle, Emydoidea brandingii, in Massachusetts. Herpetologica 33(4):410-414. 

Graham, T. E., and T. S. Doyle.

1979. Dimorphism, courtship, eggs, and hatchlings of the Blanding's turtle, Emydoidea blandingii, (Reptilia, Testudines, Emydidae) in Massachusetts. J. Herpeto1. 13(1):125-127.

Graham, T. E., and V. H. Hutchison.

1969. Centenarian box turtles. Int. Turtle and Tortoise Soc. J. $3(3): 24-29$.

Grizzel1, R. A., Jr.

1949. The hibernation site of three snakes and a salamander. Copeia 1949(3):231-232.

Gruberg, E. R., and R. V. Stirling.

1972. Observations on the burrowing habits of the tiger salamander, Ambystoma tigrinum. Herpetol. Rev. 4(3):85-89.

Hairston, N. H.

1949. The local distribution and ecology of the plethodontid salamanders of the southern Appalachians. Ecol. Monogr. 19(1): 47-73.

Hamilton, W. J., Jr.

1932. The food and feeding habits of some eastern salamanders. Copeia 1932(1):83-86.

1934. The rate of growth of the toad [Bufo a. comericanus (Holbrook)] under natural conditions. Copeia 1934(2):88-90.

1948. The food and feeding behavior of the green frog, Rana clamitans (Latreille), in New York state. Copeia 1948(3):203-207. 1951. The food and feeding behavior of the garter snake in New York. Am. Midl. Nat. 46(2):385-390.

1954. The economic status of the toad. Herpetologica 10:37-40. 

Hamilton, W. J., Jr., and J. A. Pollack.

1961. The food habits of some lizards from Fort Benning, Georgia. Herpetologica 17(2):99-106.

Hammer, D. A.

1969. Parameters of a marsh snapping turtle population, Lacreek Refuge, South Dakota. J. Wildl. Manage. 33:995-1005.

Hassinger, D. D., J. D. Anderson, and G. H. Dalrymple.

1970. The early life history and ecology of Ambystoma tigrinum and Ambystoma opacum in New Jersey. Am. Midl. Nat. 84(2):474-495.

Hay, W. P.

1904. A revision of Malaclemms, a genus of turtles. Bull., U.S. Bur. Fish. 24:1-20.

Healy, W. R.

1974. Population consequences of alternative life histories in Notophthalmus v. viridescens. Copeia 1974(1):221-229.

Heatwole, H.

1961. Habitat selection and activity of the wood frog, Rana syzvatica (LeConte). Am. Midl. Nat. 66:301-313.

1962. Environmental factors influencing local distribution and activity of the salamander, Plethodon cinereus. Ecology 43:460-472.

Hedeen, S. E.

1970. The ecology and life history of the mink frog, Rana septentrionalis (Baird). Ph.D. Thesis, Univ., Minn., Minneapolis. 132pp. [From Diss. Abstr. 31:3985B, 1970.]

1972. Postmetamorphic growth and reproduction of the mink frog, Rana septentrionalis (Baird). Copeia 1972(1):169-175. 1977. Rana septentrionalis (Baird). Cat. Am. Amphib. Rept. 202.1-202.2. 

Herreid, C. F., and S. Kinney.

1967. Temperature and development of the wood frog, Rana sylvatica, in Alaska. Ecology 48:579-589.

Highton, R.

1956. The life history of the slimy salamander, Plethodon glutinosus, in Florida. Copeia 1956(2):75-93.

1962. Geographic variation in the life history of the slimy salamander. Copeia 1962(3):597-613.

Hillis, R. E.

1969. Certain aspects of the ecology of Cryptobranchus alleganiensis (Daudin) emphasizing home range, population structure and homing. Ed.D. Thesis, Penn. State Univ. 60pp. 1969. [From Diss. Abstr. $31(4 B): 2367-B, 1970$.

Hoff, J. G.

1977. A Massachusetts hibernation site of the red-backed salamander, Plethodon cinereus. Herpetol. Rev. 8(2):33.

Huheey, J. E., and R. A. Brandon.

1973. Rock-face populations of the mountain salamander, Desmognathus ochrophaeus, in North Carolina. Ecol. Monogr. 43(1):59-77.

Hurlbert, S. H.

1969. The breeding migrations and interhabitat wandering of the vermillion-spotted newt, Notophthalmus viridescens (Rafinesque). Ecol. Monogr. 39(4):465-488.

1970. The post-larval migration of the red-spotted newt, Notophthalmus viridescens (Rafinesque). Copeia 1970(3):515-528.

Ingram, W. M., and E. C. Raney.

1943. Additional studies on the movement of tagged bulifrogs, Rana catesbeiona (Shaw). Am. Midl. Nat. 29:239-241. 

Iverson, J. B.

1977. Kinostermon subrubmum. Cat. Am. Amphib. Rept. 193.1-193.4.

1979. Reproduction and growth of the mud turtle, Kinosternon subrubrum (Reptilia, Testudines, Kinosternidae), in Arkansas. J. Herpeto1. 13(1):105-111.

Jameson, E. W., Jr.

1944. Food of the red-backed salamander. Copeia 1944(3):145-147.

1947. The food of the western cricket frog. Copeia 1947(3):212.

Jaslow, A. P., and R. C. Vogt.

1977. Identification and distribution of HyZa versicolor and Hyla chrysoscelis in Wisconsin. Herpetologica 33(2):201-205.

Johnson, J. E., and A. S. Goldberg.

1975. Movement of larval two-lined salamanders (Eurycea bislineata) in the Mill River, Massachusetts. Copeia 1975(3):588-589.

Karns, D. R.

1980. Ecological risks for amphibians at toxic bog water breeding sites in northern Minnesota. (Abstract). Proc. 1980 Joint Annu. Herpetologists League/Soc. for the Study of Amphib. Rept., Milwaukee, Wisconsin.

Keen, W. H.

1979. Feeding and activity patterns in the salamander Desmognathus ochrophaeus (Amphibia, Urodela, Plethodontidae). J. Herpetol. $13(4): 461-467$.

Keen, W. H., and L. P. Orr.

1980. Reproductive cycle, growth and maturation of northern female (Desmognathus ochrophaeus). J. Herpetol. 14(1):7-10.

Keenlyne, K. D., and J. R. Beer.

1973. Food habits of Sistmumus c. catenatus. J. Herpetol. $7(4): 382-384$. 

Kiviat, E.

1980. A Hudson River tidemarsh snapping turtle population. Pages 158-168

In Trans. Northeast. Sec. Wildl. Soc. 37th Northeast. Fish and Wildl. Conf., April 27-30, 1980, Ellenville, New York. 265pp.

Klauber, L. M.

1972. Rattlesnakes. 2 vol. Univ. Calif. Press, Berkeley and Los Angeles. 1533pp.

Klingener, $D$.

1957. A marking study of the short-headed garter snake in Pennsylvania. Herpetologica 13:100.

Kramek, W. C.

1972. Food of the frog Rana septentrionalis in New York. Copeia 1972:390-392.

1976. Feeding behavior of Rana septentrionalis (Amphibia, Anura, Ranidae). J. Herpeto1. 10(3):251-252.

Kramer, D. C.

1974. Home range of the western chorus frog Pseudacris t. triseriata. J. Herpetol. $8(3): 245-246$.

Krysik, A. J.

1980. Microhabitat selection and brooding phenology of Desmognathus f. fuscus in western Pennsylvania. J. Herpetol. 14(3):291-292.

Lagler, K. F.

1943. Food habits and economic relations of the turtles of Michigan with special reference to game management. Am. Midl. Nat. 29(2): $257-312$.

Landre, E.

1980. The blue-spotted salamander sanctuary. Mass. Audubon Soc. Bul1 . 20(4):6-7. 

Laze11, J. D., Jr.

1968. Blue-spotted salamander. Mass. Audubon Soc. Bull. 53(2): 20-25.

1972. Reptiles and amphibians in Massachusetts. Mass. Audubon Soc., Lincoln, Mass. 34pp.

1976. This broken Archipelago. Demeter Press, Qudrangle, New York

Times Book Co. 260pp.

1979. Teetering toward oblivion. Mass. Wildl. 30(4):15-18.

Lindquist, S. B., and M. D. Bachman.

1980. Feeding behavior of the tiger salamander, Ambystoma tigrinum. Herpetologica 36(2):144-158.

Linzey, D. W.

1967. Food of the leopard frog, Rana p. pipiens, in central New York. Herpetologica 23(1):11-17.

Logier, E. B. S.

1952. The frogs, toads and salamanders of eastern Canada. Clarke, Irwin and Co., Ltd., Canada. 127pp.

Lomax, J. L., J. M. Galli, and A. E. Galli.

1980. The wildlife of Cape May County, New Jersey: a habitat guide to the vertebrate fauna. Cent. Environ. Res., Stockton State Coll., Pomona, New Jersey, and The Wetlands Inst., Box 398, Stone Harbor, New Jersey. 93pp.

Lotter, F.

1978. Reproductive ecology of the salamander PZethodon cinereus (Amphibia, Urodela, Plethodontidae) in Connecticut. J. Herpetol. $12(2): 231-236$.

Lynn, W. G., and T. vonBrand.

1945. Studies on the oxygen consumption and water metabolism of turtle embryos. Biol. Bul1. 88(2):112-125. 

MacNamara, M. C.

1977. Food habits of terrestrial adult migrants and immature red efts of the red-spotted newt Notophthalmus viridescens. Herpetologica $33(1): 127-132$.

Mahmoud, I. Y.

1967. Courtship behavior and sexual maturity in four species of Kinosternid turtles. Copeia 1967(2):314-319.

1968. Feeding behavior in Kinosternid turtles. Herpetologica $24(2): 300-305$.

1969. Comparative ecology of the Kinosternid turtles of Oklahoma. Southwest. Nat. 14:31-66.

Marsha11, W. H., and M. F. Buell.

1955. A study of the occurrence of amphibians in relation to a bog succession, Itasca State Park, Minnesota. Ecology 36(3): 381-387.

Martof, B. S.

1953a. Territoriality in the green frog, Rana clamitans.

Ecology $34(1): 165-174$.

1953b. Home range and movements of the green frog, Rana clamitans.

Ecology $34(3): 529-543$.

1956. Factors influencing size and composition of populations of

Rana clomitons. Am. Midl. Nat. 56(1):224-245.

1970. Rana sylvatica (LeConte). Cat. Am. Amphib. Rept. 86.1-86.4.

1975. Pseudotriton muber (Latreille). Cat. Am. Amphib. Rept. 167.1-167.3.

Martof, B. S., W. M. Palmer, J. R. Bailey, and J. R. Harrison III. 1980. Amphibians and reptiles of the Carolinas and Virginia. Univ. North Carolina Press, Chapel Hill. 264pp. 

Maynard, E. A.

1934. The aquatic migration of the toad, Bufo americanus (LeConte). Copeia 1934(4):174-177.

McCauley, R. H., Jr.

1945. The reptiles of Maryland and District of Columbia. Hagerstown, Maryland. Publ. by author. 194pp.

McCoy, C. J.

1973. Emydoidea blondingii. Cat. Am. Amphib. Rept. 136.1-136.4.

McCoy, C. J., Jr., and A. V. Bianculli.

1966. The distribution and dispersal of Heterodon platyrhinos in

Pennsylvania. J. Ohio Herpetol. Soc. 5(4):153-158.

Mecham, J.S.

1967. Notophthalmus viridescens. Cat. Am. Amphib. Rept. 53.1-53.4.

Messeling, E.

1953. Rattlesnakes in southwestern Wisconsin. Wis. Conserv. Bu11.

No. $18(10): 21-23$.

Minton, S. A., Jr.

1944. Introduction to the study of the reptiles of Indiana.

Am. Midl. Nat. 32:438-477.

1954. Salamanders of the Ambystoma jeffersonianum complex in

Indiana. Herpetologica 10(3):173-179.

1972. Amphibians and reptiles of Indiana. The Indiana Acad. Sci., Indianapolis. $346 \mathrm{pp}$.

Mittleman, M. B.

1966. Eurycea bislineata (Green). Cat. Am. Amphib. Rept. 45.1-45.4. 

Mohr, C. E.

1943. The eggs of the long-tailed salamander, Eumycea Zongicauda (Green). Proc. Penn. Acad. Sci. 17:86. (Information obtained from Minton 1972.)

Moore, J. E., and E. H. Strickland.

1955. Further notes on the food of Alberta amphibians. Am. Midl. Nat. 54(1):253-256.

Morgan, A. H., and M. C. Grierson.

1932. Winter habits and yearly food consumption of adult spotted newts, Tritums vimidescens. Ecology 13:54-62.

Nei11, W. T.

1963. BemidactyZium scutatum. Cat. Am. Amphib. Rept. 2.1-2.2.

Nemuras, $K$.

1969. Survival of the Muhlenberg. Int. Turtle and Tortoise Soc. J. $3(5): 18-21$.

Newman, H. H.

1906. The habits of certain tortoises. J. Comp. Neur. Psych. $16: 126-152$.

Nichols, J. T.

1939. Range' and homing of individual box turtles. Copeia 1939(3): 125-127.

1947. Notes on the mud turtle. Herpetologica 3:147-148.

Nickerson, M. A., and C. E. Mays.

1973. A study of the Ozark hellbender Cryptobranchus alleganiensis bishopi. Ecology 54(5):1164-1165. 

Noble, G. K., and M. K. Brady.

1933. Observations on the life history of the marbled salamander, Ambystoma opacum (Gravenhorst). Zoologica 11:89-132.

Nobel, G. K., and H. J. Clausen.

1936. The aggregation behavior of Storemia dekayi and other snakes, with especial reference to the sense organs involved. Ecol. Monogr. $6: 269-316$.

Obbard, M. E., and R. J. Brooks.

1980. Nesting migrations of the snapping turtle (Chelydra sempentina). Herpetologica $36(2): 158-162$.

01 dham, R. S.

1966. Spring movements in the American toad, Bufo americanus.

Can. J. Zoo1. 44(1):63-100.

01 iver, J. A.

1955. The natural history of North American amphibians and reptiles.

D. Van Nostrand Co., Inc. Princeton, New Jersey. 359pp.

Oplinger, C. S.

1967. Food habits and feeding activity of recently transformed and adult Hyza c. crucifer (Wied). Herpetologica 23(3):209-217.

Organ, J.A.

1961. Studies of the local distribution, life history, and population dynamics of the salamander genus Desmognathus in Virginia. Ecol. Monogr. $31(2): 189-220$.

Pearse, A. S.

1923. The abundance and migration of turtles. Ecology 4(1):24-28. 

Pearson, P. G.

1955. Population ecology of the spadefoot toad, Scaphiopus $h$. holbrooki. Ecol. Monogr. 25:233-267.

1957. Further notes on the population ecology of the spadefoot toad. Ecology 38(4):580-586.

Petersen, R. C.

1970. Connecticut's venomous snakes. Hartford: State Geol. and Nat. Hist. Surv. Bu11. No. 103. 40pp.

Pope, C. H.

1939. Turtles of the United States and Canada. Alfred A. Knopf, Inc., New York. 343pp. (Reprint 1946)

1944. Amphibians and reptiles of the Chicago area. Chicago Nat. Hist. Mus. Press, Chicago. 275pp.

Possardt, E. E.

1974. The breeding biology and larval development of the wood frog (Rana sylvatica). Unpub1. Dept. For. and Wild1. Manage., Univ. Mass., Amherst. $6 \mathrm{pp}$.

Pough, F. H.

1976. Acid precipitation and embryonic mortality of spotted salamanders (Ambystoma macuzatum). Science 192:68-70.

Pough, F. H., and R. E. Wilson.

1976. Acid precipitation and reproductive success of Ambystoma salamanders. Pages 531-544 In Proc. Int. Symp. on Acid Precipitation and For. Ecosystem. USDA For. Serv. Gen. Tech. Rep. NE-23, Northeast. For. Exp. Stn., Upper Darby, Penn.

Rand, A. S.

1950. Leopard frogs in caves in winter. Copeia 1950(4):324. 

Raney, E. C.

1940. Summer movements of the bullfrog, Rana catesbeiana (Shaw),

as determined by the jaw-tag method. Am. Midl. Nat. 23(3):733-745.

Raney, E. C., and R. M. Roecker.

1947. Food and growth of two species of watersnakes from western

New York. Copeia 1947(3):171-174.

Richmond, N. D.

1947. Life history of Scaphiopus $h$. holbrookii (Harlan). Part I:

Larval development and behavior. Ecology 28(1):53-67.

Ries, K. M., and E. D. Bellis.

1966. Spring food habits of the red-spotted newt in Pennsylvania. Herpetologica 22(2):152-155.

Risely, P. L.

1932. Observations on the natural history of the common musk turtle, Stemotherus odoratus (Latreille). Pap. Mich. Acad. Sci., Arts and Letters $17: 685-711$.

Rossman, D. A.

1970. Thamnophis saumitus (Linnaeus). Cat. Am. Amphib. Rept. 99.1-99.2.

Sayler, A.

1966. The reproductive ecology of the red-backed salamander, Plethodon cinereus, in Maryland. Copeia 1966:183-193.

Schaaf, R. T., Jr., and P. W. Smith.

1971. Rana palustris (LeConte). Cat. Am. Amphib. Rept. 117.1-117.3.

Schlauch, F. C.

1975. Agonistic behavior in a suburban Long Island population of the smooth green snake, opheodrys vernalis. Engelhardtia 6(2):25-26. 

Schmidt, K. P., and D. D. Davis.

1941. Field book of snakes. G. P. Putnam \& Sons, New York. 365pp.

Seibert, H. C., and C. W. Hagen, Jr.

1947. Studies on a population of snakes in Illinois. Copeia 1947(1): 6-22.

Semlitsch, R. D.

1980a. Geographic and local variation in population parameters of the slimy salamander (Plethodon glutinosus). Herpetologica $36(1): 6-16$.

1980b. Terrestrial activity and summer home range of the mole salamander (Ambystoma talpoideum). Can. J. Zool. 59(2):315-322.

Sexton, 0. J.

1959. Spatial and temporal movements of a population of the painted turtle, Chrysemys picta marginata (Agassiz). Ecol. Monogr. 29(2): $113-140$.

Shoop, C. R.

1965. Orientation of Ambystoma maculatum: movements to and from breeding ponds. Science 149(3683):558-559.

Smith, H. M.

1946. Handbook of lizards. Comstock Publ. Assoc., Ithaca, New York. 557pp.

1956. Handbook of amphibians and reptiles of Kansas. 2nd ed. Mus. Nat. Hist., Misc. Publ. No. 9. Univ. Kansas Publ., Topeka. $356 \mathrm{pp}$.

1978. Amphibians of North America: a guide to field identification. Western Publ. Co., Inc., Racine, Wisc. 160pp. 

Smith, P. W.

1961. The amphibians and reptiles of Illinois. Illinois Nat. Hist. Surv. Bu11. 28(1):1-298.

1963. Plethodon cinereus. Cat. Am. Amphib. Rept. 5.1-5.3.

Smith, P. W., and H. M. Smith.

1952. Geographic variation in the lizard, Eumeces anthracinus. Univ. Kansas Sci. Bull. 34:679-694. (Information obtained from Minton 1972.)

Stewart, 0 .

1974. Canadian endangered species. Gage Publ., Toronto. 172pp.

Stewart, M. M.

1956a. Certain aspects of the natural history and development of the northern two-lined salamander, Eurycea b. bis Zineata (Green), in the Ithaca, New York region. Ph.D. Diss., Cornel1 Univ. 156pp.

[From Diss. Abstr. 16(12):2567, 1956.]

1956b. The separate effects of food and temperature differences on development of marbled salamander larvae. J. Elisha Mitchell Sci. Soc. $72(1): 47-56$.

1961. Biology of the Allegany Indian Reservation and vicinity.

Part 3: the amphibians, reptiles and mammals. New York State Mus. Sci. Serv. Bu11. (383):63-88.

1975. Habitat management in the Adirondack Park. New York Environ. News $2(17): 1-2$.

Stewart, M. M., and P. Sandison.

1972. Comparative food habits of sympatric mink frogs, bullfrogs, and green frogs. J. Herpetol. 6(3/4):241-244.

Stickel, L. F.

1950. Population and home range relationships of the box turtle, Terrapene c. carolina (Linnaeus). Ecol. Monogr. 20:351-378. 

Stickel, L. F., W. H. Stickel, and F. C. Schmid.

1980. Ecology of a Maryland population of black rat snakes (EZaphe o. obsoleta). Am. Midl. Nat. 103(1):1-14.

Stickel, W. H., and J. B. Cope.

1947. The home ranges and wanderings of snakes. Copeia 1947(2): 127-136.

Stille, W. T.

1952. The nocturnal amphibian fauna of the southern Lake Michigan beach. Ecology 33(2):149-162.

1954. Eggs of the salamander Ambystoma jeffersonianzom in the Chicago area. Copeia 1954(4):300.

Stone, W. B., E. Kiviat, and S. A. Butkas.

1980. Toxicants in snapping turtles. New York Fish and Game J. $27(1): 39-50$.

Surface, H. A.

1906. The serpents of Pennsylvania. Penn. Dep. Agric. Div. Zool. Bu11. 4(4-5):113-202.

1908. First report on the economic features of the turtles of Pennsylvania. Penn. Dep. Agric. Div. Zool. Bu11. 6:105-196.

1913. The amphibians of Pennsylvania. Bimonthly Penn. Dep. Agric. Div. Zoo1. Bul1. 3(3-4):65-152, 1-11.

Swanson, P. L.

1952. The reptiles of Venango County, Pennsylvania. Am. Midl. Nat. $47(1): 161-182$.

Taub, F. B.

1961. The distribution of the red-backed salamander, PZethodon $c$. cinereus, within the soil. Ecology 42(4):681-698. 

Thompson, E. L., J. E. Gates, and G. J. Taylor.

1980. Distribution and breeding habitat selection of the Jefferson salamander, Ambystoma jeffersonianum in Maryland. J. Herpetol. $14(2): 113-120$.

Tilley, S. G.

1968. Size-fecundity relationships and their evolutionary implications in five desmognathine salamanders. Evolution 22:806-816.

1970. Aspects of the reproductive and population ecology of Desmognathus ochrophaeus in the southern Appalachian mountains. Ph.D. Thesis, Univ. Mich. 293pp. [From Diss. Abstr. Int. $31(8 B): 5084,1971$.

1972. Aspects of parental care and embryonic development in Desmognathus ochrophaeus. Copeia 1972:532-540.

1973. Desmognathus ochrophaeus. Cat. Am. Amphib. Rept. 129.1-129.4.

Tinkle, D. W.

1961. Geographic variation in reproduction, size, sex ratio, and maturity of Sternothemus odoratus (Testudinata:Chelydridae). Ecology 42(1):68-76.

Tinkle, D. W., and R. E. Ballinger.

1972. Sceloporus undulatus: a study of the intraspecific comparative demography of a lizard. Ecology 58(4):570-584.

Trapido, H., and R. T. Clausen.

1938. Amphibians and reptiles of eastern Quebec. Copeia 1938(3): 117-125.

Uhler, F. M., C. Cottom, and T. E. Clarke.

1939. Food of snakes of the George Washington National Forest, Virginia. Trans. Fourth North Am. Nat. Resour. and Wildl. Conf.: 605-622. 

USDA Forest Service.

1981. Compartment prescription handbook. Chapter 300--Wildlife Habitat System, FSH 2409.21d - R9, Amendment Draft. 57pp.

Uzze11, T. M., Jr.

1964. Relations of the diploid and triploid species of the Ambystoma jeffersonianum complex (Amphibia, Caudata). Copeia 1964 (2):257-300.

1967a. Ambystoma jeffersonianum. Cat. Am. Amphib. Rept. 47.1-47.2.

1967b. Ambystoma Zaterale. Cat. Am. Amphib. Rept. 48.1-48.2.

1967c. Ambystoma platineum. Cat. Am. Amphib. Rept. 49.1-49.2.

1967d. Ambystoma tremblayi. Cat. Am. Amphib. Rept. 50.1-50.2.

Wacasey, J. W.

1961. An ecological study of two sympatric species of salamanders, Ambystoma maculatum and Ambystoma jeffersonianum, in southern Michigan. Ph.D. Thesis, Mich. State Univ., East Lansing. 129pp. [From Diss. Abstr. 23(1):368, 1962.]

Wasserman, A. 0.

1968. Scaphiopus holbrookii (Harlan). Cat. Am. Amphib. Rept. $70.1-70.4$.

Webb, R. G.

1961. Observations on the life histories of turtles (genus Pseudemys and Graptemys) in Lake Texoma, Oklahoma. Am. Midl. Nat. 56:193-214.

1973. Trionyx spiniferus (LeSueur). Cat. Am. Amphib. Rept. 140.1-140.4.

Wells, K. D.

1976. Multiple egg clutches in the green frog (Rana clamitans). Herpetologica 32(1):85-87.

1977. Territoriality and male mating success in the green frog (Rana clamitans). Ecology 58:750-762. 

Wells, K. D., and R. A. Wells.

1976. Patterns of movement in a population of the slimy salamander, Plethodon glutinosus, with observations on aggregations.

Herpetologica 32(2):156-162.

Wilder, I. W.

1913. The life history of Desmognathus fusca. Biol. Bull. 24(4):251-292, (5):293-342.

1917. On the breeding habits of Desmognathus fusca. Biol. Bull. $32: 13-20$.

Williams, J. E.

1952. Homing behavior of the painted turtle and musk turtle in a lake. Copeia 1952(2):76-82.

Williams, K. L.

1978. Systematics and natural history of the American milk snake, Lampropeltis triangulum. Milwaukee Publ. Mus. Press, Milwaukee, Wisc. 258pp.

Williams, P. K.

1973. Seasonal movements and population dynamics of four sympatric mole salamanders, genus Ambystoma. Ph.D. Thesis, Indiana Univ., Bloomington. (Information obtained from Semlitsch 1980b.)

Wilson, L. D.

1978. Coluber constrictor (Linnaeus). Cat. Amphib. Rept. 218.1218.4 .

Wilson, R. E.

1976. An ecological study of Ambystoma maculatum and Ambystoma jeffersonianum. Ph.D. Diss., Cornell Univ., Ithaca, New York. (Information obtained from Thompson et al. 1980.) 

Wood, J. T.

1949. Observations on Natrix septemvittata (Say) in southwestern Ohio. Am. Midl. Nat. 42(3):744-750.

1953. Observations on the complements of ova and nesting of the four-toed salamander in Virginia. Am. Nat. 87:77-86.

Wright, A. H.

1914. North American Anura: Life histories of the Anura of Ithaca, New York. Carnegie Inst., Washington, D.C., Publ. No. 197. 98pp.

Wright, A. H., and A. A. Allen.

1909. The early breeding habits of Ambystoma punctation. Am. Midl. Nat. 43(513):687-692.

Wright, A. H., and A. A. Wright.

1949. Handbook of frogs and toads. Comstock Publ. Assoc., Ithaca, New York. 625pp.

1957. Handbook of snakes. 2 vol. Comstock Publ. Assoc., Ithaca, New York. 1133pp.

Wright, B. A.

1941. Habit and habitat studies of the massasauga rattlesnake [Sistrumus c. catenatus (Rafinesque)] in northeastern Illinois. Am. Midl. Nat. 25:659-672. 

USCDEATIMENT OE AGRTLUTURE

USOA-FOREST SERVICE.

REMFMAIR:

SHY NATIONAL FOREST

DETRACT PADRE

$5 \sqrt{3}$

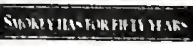

Sheryl.

We must

Sheryl.
We must
have the last copy of
this book. Here's a copy
for you to pass ow. He

did talk to me a while ago, but $l$ didst realize that there were xt other copies available.

fax E. Joke

Help Smokey Prevent Forest Fires x 40 



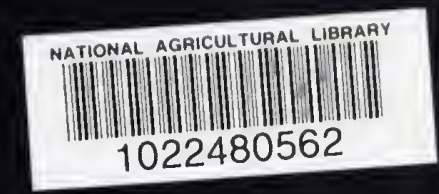


